This report was prepared as an oceowpt of work tponesored by in agency of the United States

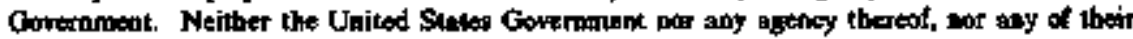

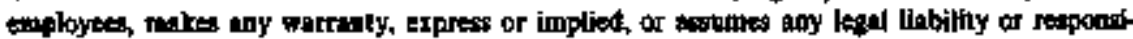
bility for line accuracy, completeress, of usefulates of any information, apparatus, produch, of

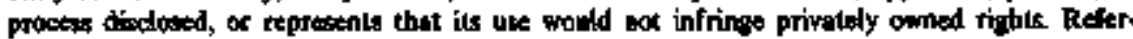

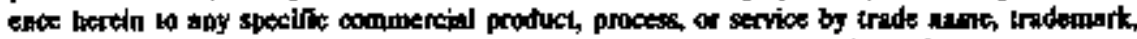

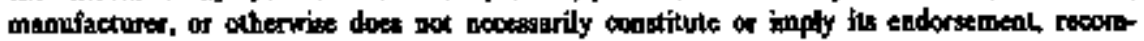

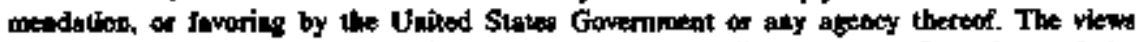

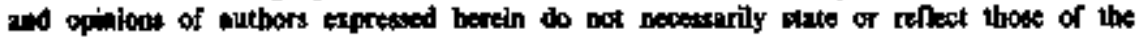

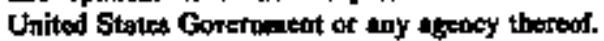

\title{
Waste Management Facilities Cost Information for Transportation of Radioactive and Hazardous Materials
}

\author{
Fred Felzollahi \\ David Shropahire \\ Bavid Burton
}

Publiahed September 1994

\author{
Idaho Natlonal Engineering Laboratory \\ EG\&G Idaho, Inc. \\ Idaho Falls, Idaho 83415
}

\author{
Prepured for the \\ U.S. Dopertment of Enery \\ Aseletent Secrotery tor Environementel Management \\ Under DOE Jdaho Operationa Oilice \\ Contraet DE-AC07-761DO1670
}





\section{DISCLAIMER}

Portions of this document may be Hlegible in electronic image products. Images are produced from the best available original document. 


\section{Waste Management Facilities \\ Cost Information for \\ Transportation of Radioactive and Hazardous \\ Materials}

Prepared by:
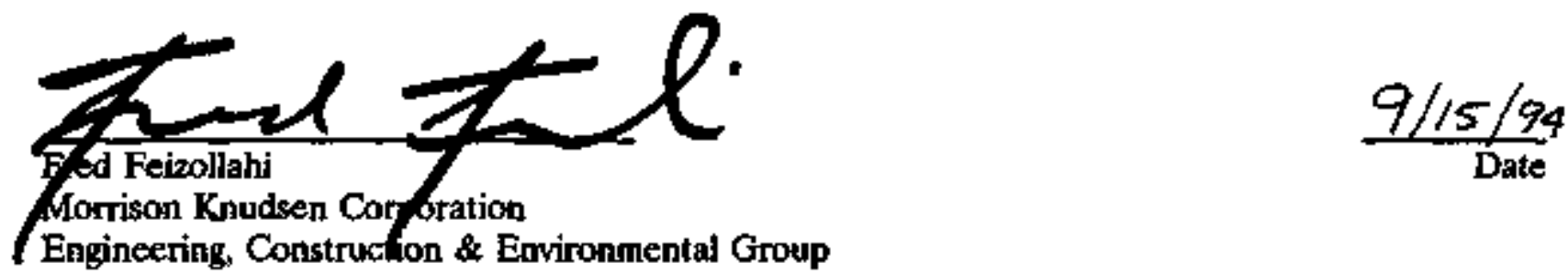

$2-06$

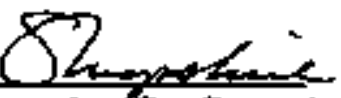

David Shropshire, Complex Configuration Technical Support,

EG\&G Idaho, Inc.

Reviewed by:

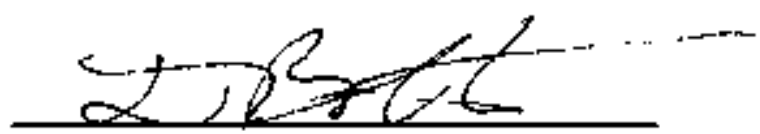

Derek Boiton

Motrison Knudsen Corporation

Date

Engitneering, Construction \& Environmental Group

Reviewed and approved by:

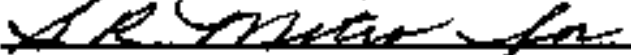

Éric Williams, Manager, Radi6active Waste Technology Initiative, EG\&G Idaho, Inc. 


\begin{abstract}
This report contains cost information on the U.S. Department of Energy (DOE) Complex waste streams that will be addressed by DOE in the programmatic environmental impact statement (PEIS) project. It describes the results of the task comnissioned by DOE to develop cost information for transportation of radioactive and bazardous waste. It contains transportation costs for most types of DOE waste streams: bow-level waste (LLW), mixed low-level waste (MLLW), alpha LLW and alpha MLLW, greater-than-Class C (GTCC) LLW and DOE equivalent waste, transuranic (TRU) waste, spent nuclear fuel (SNF), and hazardous waste. Unit rates for transportation of contact-handled ( $<200$ mrenthr contact dose) and remote-handled ( $>200$ mrem/hr contact dose) radioactive waste are estimated.

Land transportation of radioactive and hazardous waste is subject to regulations promulgated by DOE, the U.S. Department of Transportation (DOT), the U.S. Nuclear Regulatory Commission (NRC), and state and local agencies. The cost estimates in this report assume compliance with applicable regulations.
\end{abstract}




\section{ACKNOWLEDGMENTS}

The authors would like to acknowitedge the efforts of those who contributed to this report: Fred Monette and Tony Policastro of Argonne-East, and Steve Maheras of Scientific Applications International Corporation for the extra effort required in reviewing this report. 



\section{CONTENTS}

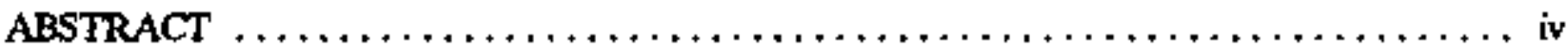

ACKNOWLEDGMENTS $\ldots \ldots \ldots \ldots \ldots \ldots \ldots \ldots \ldots \ldots \ldots \ldots \ldots \ldots \ldots \ldots \ldots$

ACRONYMS $\ldots \ldots \ldots \ldots \ldots \ldots \ldots \ldots \ldots \ldots \ldots \ldots \ldots \ldots \ldots \ldots \ldots \ldots \ldots \ldots$

1. INTRODUCTION $\ldots \ldots \ldots \ldots \ldots \ldots \ldots \ldots \ldots \ldots \ldots \ldots \ldots \ldots \ldots \ldots \ldots \ldots \ldots \ldots$

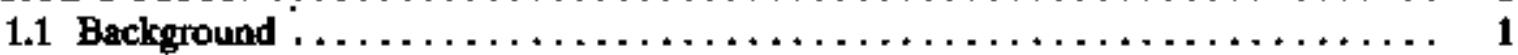

1.2 Transportation Cost Estimating Methods $\ldots \ldots \ldots \ldots \ldots \ldots \ldots \ldots \ldots \ldots$,

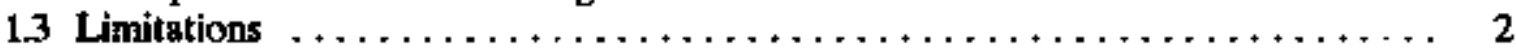

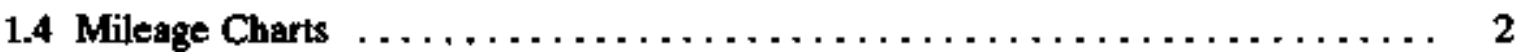

1.5 Report Organization $\ldots \ldots \ldots \ldots \ldots \ldots \ldots \ldots \ldots \ldots \ldots \ldots \ldots \ldots \ldots$

2 LLW, MLLW, ALPHA LLW, ALPHA MLLW, AND

GTCCIDOE EQUTVALENT WASTE $\ldots \ldots \ldots \ldots \ldots \ldots \ldots \ldots \ldots \ldots \ldots \ldots \ldots \ldots$

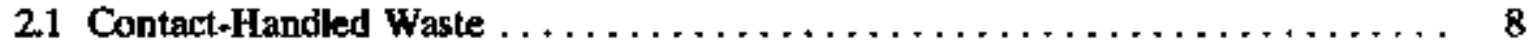

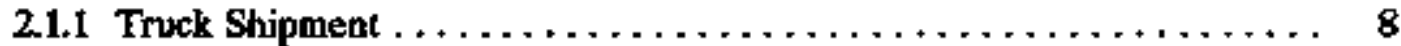

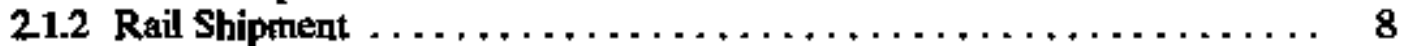

2.2 Remote-Handled Waste $\ldots \ldots \ldots \ldots \ldots \ldots \ldots \ldots \ldots \ldots \ldots \ldots \ldots \ldots \ldots$

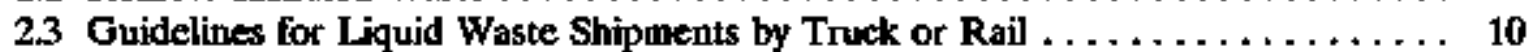

2.4 Guidelines for Lab Pack Shipments $\ldots \ldots \ldots \ldots \ldots \ldots \ldots \ldots \ldots \ldots \ldots$

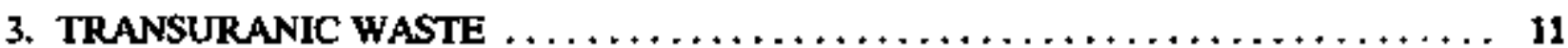

3.1 Truck Shipment of Contact-Handled Waste $\ldots \ldots \ldots \ldots \ldots \ldots \ldots \ldots \ldots \ldots 11$

3.2 Truck Shipment of Remote-Handled TRU Waste $\ldots \ldots \ldots \ldots \ldots \ldots \ldots \ldots \ldots$ I1

3.3 Rail Shipment of Contact-Handled TRU Waste $\ldots \ldots \ldots \ldots \ldots \ldots \ldots \ldots \ldots \ldots, 12$

3.4 Rail Shipments of Remote-Handled TRU Waste $\ldots \ldots \ldots \ldots \ldots \ldots \ldots \ldots \ldots \ldots 13$

4. SPENT NUCLEAR FUEL $\ldots \ldots \ldots \ldots \ldots \ldots \ldots \ldots \ldots \ldots \ldots \ldots \ldots \ldots \ldots \ldots \ldots \ldots \ldots$

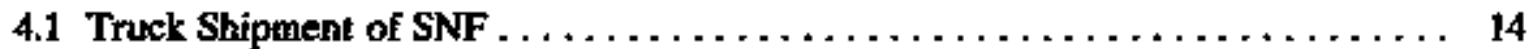

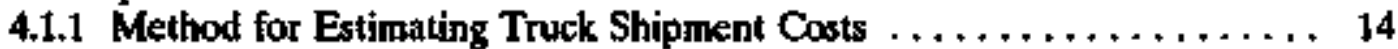

4.1.2 Guidance for Determining Number of Truck Shipments . . . . . . . 14

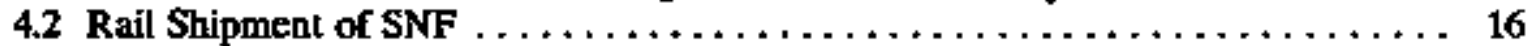

4.21 Method for Estimating Rail Shipment Costs $\ldots \ldots \ldots \ldots \ldots \ldots$

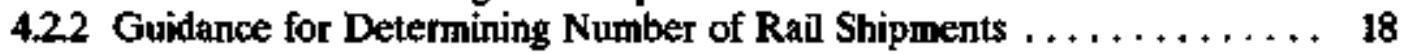

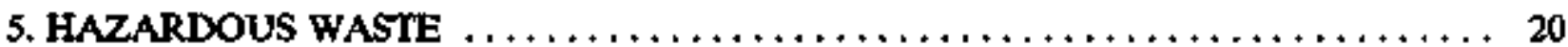

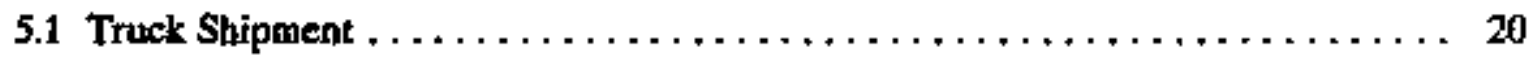

5.2 Rail Shipment $\ldots \ldots \ldots \ldots \ldots \ldots \ldots \ldots \ldots \ldots \ldots \ldots \ldots \ldots \ldots, \ldots \ldots \ldots$

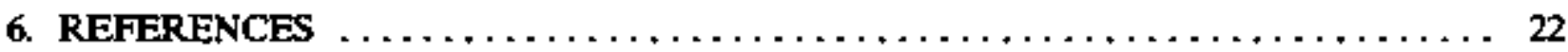

Appendix A-Methods, Bases, and Assumptions $\ldots \ldots \ldots \ldots \ldots \ldots \ldots \ldots \ldots \ldots \ldots \ldots$

Appendix B.Backup Data for Low-Level Waste Shipments $\ldots \ldots \ldots \ldots \ldots \ldots \ldots \ldots$ B-1

Appendix C-Backup Data for TRU Shipments $\ldots \ldots \ldots \ldots \ldots \ldots \ldots \ldots \ldots \ldots \ldots \ldots \ldots \ldots$ C-1 


\section{TABLES}

1. Distance (in miles) by truck between DOE sites $\ldots \ldots \ldots \ldots \ldots \ldots \ldots \ldots \ldots, 4$

2. Distance (in miles) by rail between $D O E$ sites $\ldots \ldots \ldots \ldots \ldots \ldots \ldots \ldots \ldots \ldots 6$

3. Capacity of vatious cask and canister combinations for transport of $\mathrm{N}$-reactor, highenriched uranium, and low-enriched uranium fuel by truck $\ldots \ldots \ldots \ldots \ldots \ldots 15$

4. Capacity of various cask and canister combinations for transport of N-reactor, LEU, and HEU fued by rail 


\section{ACRONYMS}

A activity (Curies)

BOY base operating year

BWR boiling water reactor

CFR Code of Federal Regulations

CPLM cost per loaded mile

DOE U.S. Department of Energy

DOT U.S. Department of Transportation

FSV Fort St. Vrain

GTCC LLW greater-than-class-C low-level waste

HEU high-entiched uranium

HTGR high temperature gas-cooled reactor

INEL Idaho National Engineering Laboratory

LEU low-enriched uranium

LEW low-level waste

MLLW mixed low-kvel waste

MPC multi-purpose canister

MRS monitored retrievable storage

NRC U.S. Nuclear Regulatory Commission

PEIS Programmatic Environmental Impact Statement

PLCC planning life-cycle cost

PWR pressurized water reactor

RH remote handled

SNF spent nuclear fuel

TRU transuranic waste

TSD treatment, storage, and disposal

UPRR Union Pacific Railroad

WIPP Waste Isolation Pilot Ptant

WMFCI Waste Management Facilities Cost Information 


\section{Waste Management Facilities Cost Information for Transportation of Radioactive and Hazardous Materials}

\section{INTRODUCTION}

\subsection{Background}

The Waste Management Facilities Cost lnformation (WMFCD) report series contains cost information on the U.S. Department of Energy (DOE) Complex waste streams that will be addressed by DOE in the Programmatic Environmental Impact Statement (PEIS) project. To date, four reports (EGG-WTD-10443, EGG-WM-10670, EGG-WM-10962, and EGG-WM-10701), covering planning life-cycle cost (PLCC) estimates for treatment, storage, and disposal (TSD) facilities, have been issued. This report describes the results of a closely related task commissioned by DOEः development of cost information for transportation of radioactive and hazardous waste.

This report contains transportation costs for most types of DOE waste streams: low-level waste (LLW), mixed low-level waste (MLLW), atpha LLW and alpha MLLW, greater-than-Class C (GTCC) LLW and DOE equivalent waste, transuranic waste (TRU), spent nuclear fuel (SNF), and hazardous waste. Unit rates for transportation of contact-handled ( $<200 \mathrm{mrem} / \mathrm{hr}$ contact cose) and remotebandled ( $>200$ mrem/hr contact dose) radioactive waste have been estimated previously, and a summary has been included in earlier WMFCI reports. In order to have a single source for obtaining transportation cost for all radioactive waste, the transportation costs for the contact- and remotehandled wastes are repeated in this report.

Land transportation of radioactive and hazardous waste is subject to regulations promulgated by DOE, the U.S. Department of Transportation (DOT), the U.S. Nuclear Regulatory Commission (NRC), and state and local agencies. The cost estimates in this report assume compliance with applicable regulations. It should be noted that the tzend is toward greater restrictions on transportation of radioactive waste (e.g, truck or tail car speed, shipping route, security escort, and personnel training requirements), which may have a signilicant impact on future costs.

\subsection{Transportation Cost Estimating Methods}

This report presents transportation unit rates in a cost-per-loaded-mile (CPLM) format. This allows the reader to determine shipping costs. The primary transportation mode is by truck, although rail has been considered where practical. The transportation cost is divided into two components: variable cost and fixed cost.

- CPLM unit rate is a variable cost dependent on the distance travelled. It has two subcomponents: carrier cost and bardware cost.

- Carrier cost covers the variable costs associated with the cargo carrier. The carrier is the entity that takes title to the waste from the shipper during transportation, i.e., 
the tracking company or rajlroad company. The carrier costs include tractor, fuel, labor (drivers), insurance, security escort, taxes, tools, permit fees, and related costs incurred while the waste or SNF is in transport.

- Hardware covers the variable costs associated with procuring and maintaining the special hardware used during the transportation of waste or SNF. Special hardware consists mainly of trailers and railroad cars equipped with special tight-sealing enclosures or shielded casks.

- Fixed costs generally consist of demurrage costs of the carrier and the hardware used in the shipment, which are independent of the distance travelled. Fixed costs are incurred during loading and unloading operations.

The cost of labor during the loading and unloading operation (e.g., crane operators and beatth physics technicians) is part of the facility operating and unaintenance costs rather than transportation costs.

\subsection{Limitations}

Appendix A must be consulted regarding limitations and qualifications that apply to developing transportation costs. To apply data from this report, the reader must consider the following:

- The CPLM rates given in this report do not include costs of labor or materials needed to load and unlond waste and SNF into the casiss or onto shipping trailers. These costs are included in the facility operating and maintenance costs.

- Only the estimate for SNF includes the cost of security escorts. This cost is estimated to be $20 \%$ of variable carrier cost for truck shipments, and $30 \%$ of cask rental rates during loaded portions of the move.

- It is assumed that all shipments will follow routes approved by the NRC.

- Rail costs are based on tariff rates and do not include special dedicated train charges.

- An internal basket has not been designed for the SNF canisters DOE intends to ship by rail.

- No criticality calculations have been performed for the SNF canister and cask recommendations. Conservative assumptions have been made regarding capacities.

- No attempt was made to estimate less than full truckload shiprnents. 


\subsection{Mileage Charts}

Tables 1 and 2 show distances between DOE sites by truck and by rail. These distances assume bypassing tumels and major cities (using beltways when available) and travelling on major highways. 1.5 Report Organization

Section 1 presents the background data and scope of this report. Sections 2 through 5 present the cost summaries for LLW, MLLW, alpha LLW, alpha MLLW, GTCC LLW; transuranic waste; SNF; and hazardous waste, respectively. Section 6 contains references. Appendix A lists the method, bases, and assumptions used during the cost-estimating process. Appendices B-F contain data used in the preparation of LLW, TRU, SNF truck, and SNF rail estimates, respectively. 
Table 1. Distance (in miles) by truck between DOE sites.

\begin{tabular}{|c|c|c|c|c|c|c|c|c|c|c|c|c|c|c|c|c|c|c|c|}
\hline Orfer ale & $\begin{array}{l}\text { Abticen } \\
-\end{array}$ & $\mathbf{A L}$ & $\mathbf{A N}$ & $\mathbf{A W}$ & LY & $\overline{B C}$ & $\overline{\mathbf{B}} \overline{\mathbf{A}}$ & $\mathrm{BN}$ & $\mathbf{F L}$ & FE & HS & Tis & $7 I^{\prime}$ & $K C$ & $\mathbf{K A}$ & Ts & LI & $\mathbf{L}$ & $\mathrm{MF}$ \\
\hline Amé Laforalory & AL & 6 & 351 & 1,235 & (1) & 675 & 894 & 1,216 & 3i & 6I & 1,503 & 1,287 & 1,129 & 234 & 1,163 & T,84 & 13353 & 1,135 & 644 \\
\hline Argomen, Fral & AN & o & 0 & 1,582 & $\mathbf{0}$ & 348 & 567 & 874 & 36 & 294 & 1,998 & 1,582 & 1,333 & 520 & 831 & 2,439 & 2,148 & 1,431 & 317 \\
\hline Argoane, Wea & AW & 0 & 0 & $\mathbf{0}$ & 0 & 1,906 & 2.125 & 2,437 & 1,572 & 1,842 & 599 & 0 & 1,177 & 1,325 & 2,393 & 963 & 972 & 1,144 & 1,875 \\
\hline Babcock \& Wilcea & LY & 0 & 0 & 0 & 0 & 0 & 0 & 0 & 0 & 0 & 2738 & 232 & 0 & 0 & 0 & 0 & 0 & 0 & 0 \\
\hline Bulelle Cotambur & BC & 0 & 0 & 0 & 0 & 0 & 23 & 653 & 380 & 113 & 2,323 & 1,906 & 1,463 & 650 & 626 & 2,463 & 2,472 & 1,552 & $\mathbf{7 2}$ \\
\hline Beatio Atomic & BA & $\mathbf{0}$ & $\mathbf{0}$ & $\mathbf{0}$ & 0 & $\mathbf{0}$ & 0 & 596 & 599 & 312 & 2,541 & 2,125 & 1,682 & 869 & 543 & 2,682 & 2,691 & $1, \pi 1$ & 291 \\
\hline Brootherven NR & BN & 0 & 0 & 0 & 0 & 0 & $\bullet$ & 0 & 906 & 760 & 2,853 & 2,437 & 2,113 & 1,299 & 241 & 2,994 & 3,003 & 2,201 & 721 \\
\hline Fermllab (FNAL) & FL & 0 & 0 & $\mathbf{0}$ & 0 & 0 & 0 & 0 & 0 & 326 & 1,975 & 1,572 & 1.359 & 519 & 863 & 2,126 & $\mathbf{2}, 138$ & 1,421 & 349 \\
\hline remald (FEMP & $\mathbf{F E}$ & 0 & 0 & 1) & 0 & 0 & 0 & 0 & 0 & 0 & $\mathbf{2 , 2 5 8}$ & 1,842 & 1,399 & 586 & 733 & 2,399 & 2,408 & 1,488 & 49 \\
\hline Hanford Site & HS & $\mathbf{0}$ & 0 & $\mathbf{0}$ & 0 & $\mathbf{0}$ & 0 & 0 & 0 & 0 & 0 & 599 & 1,593 & 1,741 & 2809 & 875 & 894 & 1560 & $2,2,91$ \\
\hline JNEL & $\mathbf{N}$ & to & o & 0 & 0 & 0 & 0 & n & 0 & $\mathbf{0}$ & 0 & 0 & 1,177 & 1,325 & 2,393 & 963 & 972 & 1,144 & 1,875 \\
\hline ITRt & $\mathbf{I}$ & 0 & 0 & 0 & 0 & 0 & 0 & 0 & 0 & 0 & $\mathbf{0}$ & 0 & 0 & Bs & 2,085 & 1,194 & 1,154 & 151 & 1,438 \\
\hline Kansal Cixy Plax & $\mathrm{KC}$ & ) & o & 0 & 0 & 0 & $\theta$ & i & 0 & $\mathbf{0}$ & 0 & 0 & 0 & 0 & 1,272 & 1.881 & 1,890 & 984 & 619 \\
\hline Ktwotha Alomic & $\mathbf{K A}$ & 0 & 0 & $\mathbf{0}$ & 0 & $\mathbf{0}$ & 0 & 0 & 0 & 0 & 0 & 0 & 0 & 0 & 0 & 2,950 & 2,959 & 2,174 & 694 \\
\hline Lawence Bertelcy & LB & 0 & 0 & $\mathbf{0}$ & 0 & $\mathbf{0}$ & 0 & 0 & $\mathbf{0}$ & $\mathbf{0}$ & $\mathbf{0}$ & ) & 0 & 0 & 0 & $\mathbf{0}$ & 45 & 1,274 & 2,432 \\
\hline Lxwrence Livermoce & L.L. & 0 & a & 0 & 0 & $\mathbf{0}$ & 0 & ) & 0 & $\mathbf{0}$ & 0 & 0 & 0 & 0 & 0 & 0 & 0 & 1,233 & 2,441 \\
\hline Lot Alamos NL & $\mathbf{L A}$ & 0 & 0 & 0 & 0 & 0 & 0 & 0 & 0 & 0 & 0 & 0 & v & 0 & 0 & 0 & $\mathbf{0}$ & 0 & 1,521 \\
\hline Mound P1ant & MP & $\mathbf{0}$ & 0 & 0 & 0 & 0 & 0 & 0 & 0 & 0 & 0 & 0 & 0 & 0 & 0 & $\mathbf{0}$ & 0 & 0 & 0 \\
\hline Ninal Reactor Fucility & NR & 0 & 0 & 0 & 0 & 0 & $\theta$ & 0 & 0 & $\mathbf{0}$ & (1) & 0 & 0 & 0 & $\theta$ & 0 & 0 & 0 & 0 \\
\hline Nowada Tesl Stte & $\mathbf{N T}$ & 0 & t & 0 & $\mathbf{0}$ & $\mathbf{0}$ & 0 & 0 & 0 & $\mathbf{0}$ & $\mathbf{0}$ & 0 & $\mathbf{0}$ & 0 & 0 & o & 0 & $\mathbf{0}$ & 0 \\
\hline ORISE & 이 & 0 & 0 & $\mathbf{0}$ & 0 & 0 & 0 & 0 & 0 & 0 & 0 & 0 & 0 & 0 & o & 0 & 0 & 0 & 0 \\
\hline Oak Ridpe Reserv. & OR & $\mathbf{0}$ & 0 & $\mathbf{0}$ & 0 & $\mathbf{0}$ & 0 & $\mathbf{0}$ & 0 & $\mathbf{0}$ & 0 & 0 & 0 & 0 & 0 & $\mathbf{0}$ & 0 & 0 & 0 \\
\hline Paduchin GDP & $\mathbf{P A}$ & v & 0 & $\mathbf{0}$ & 0 & 0 & 0 & 0 & 0 & 0 & 0 & 0 & 0 & 0 & 0 & 0 & 0 & 0 & 0 \\
\hline Pantex Plant & $\mathbf{P P}$ & 0 & 0 & 0 & 0 & 0 & 0 & 0 & 0 & $\mathbf{0}$ & 0 & 0 & 0 & 0 & 0 & 0 & 0 & 0 & 0 \\
\hline Portsnovih GDP & Po & 0 & 0 & 0 & 0 & 0 & 0 & 0 & 0 & 0 & 0 & 0 & 0 & 0 & 0 & 0 & 0 & 0 & 0 \\
\hline Priaceton PPL & PR & v & 0 & 0 & 0 & $\mathbf{0}$ & 0 & 0 & 0 & 0 & 0 & 0 & $\theta$ & 0 & 0 & 0 & 0 & 0 & 0 \\
\hline Reactire Metals & RM & $\mathbf{0}$ & 0 & 0 & 0 & 0 & 0 & 0 & 0 & $\mathbf{0}$ & 0 & 0 & 0 & 0 & 0 & ) & 0 & 0 & 0 \\
\hline Rocty Fials Plapl & RF & 0 & $\mathbf{0}$ & 0 & 0 & $\mathbf{0}$ & $\theta$ & 0 & 0 & 0 & 0 & $\mathbf{0}$ & 0 & 0 & 0 & 0 & 0 & 0 & 0 \\
\hline SNt, Aboupuedic & SA & 0 & 0 & 0 & 0 & 0 & 0 & 0 & 6 & 0 & 0 & 0 & 0 & 0 & 0 & 0 & 0 & 0 & 0 \\
\hline SNL, Lwermore & SL & 0 & 0 & 0 & 6 & 0 & 0 & $\mathbf{0}$ & 0 & 0 & 0 & 0 & 0 & 0 & $\mathbf{0}$ & $\mathbf{0}$ & 0 & 0 & 0 \\
\hline Savannal River & \$R & 0 & 0 & 0 & 0 & $\mathbf{0}$ & 0 & $\mathbf{0}$ & 0 & 0 & 0 & $\mathbf{0}$ & 0 & 0 & 0 & 0 & 0 & $\mathbf{0}$ & 0 \\
\hline SLAC & sT & 0 & 0 & 0 & 0 & 0 & 0 & 0 & $\mathbf{0}$ & 0 & 0 & 0 & 0 & 0 & 0 & $\mathbf{0}$ & 0 & 0 & 0 \\
\hline Weat Valky DP & Wv & 0 & 0 & 0 & 0 & $\mathbf{0}$ & 0 & 0 & 0 & 0 & 0 & 0 & 0 & 0 & 0 & 0 & 0 & 0 & 0 \\
\hline WLPP & w & 0 & 0 & 0 & 0 & 0 & 0 & 0 & o & 0 & 0 & o & 0 & 0 & o & ( & 0 & 0 & 0 \\
\hline Yutca Mksuntain, NV & $\mathbf{M M}$ & 0 & 0 & 0 & o & 0 & $\mathbf{0}$ & 0 & 0 & 0 & 0 & 0 & 0 & 0 & 0 & 0 & 0 & 0 & 0 \\
\hline
\end{tabular}


Table 1. (Cont'd)

\begin{tabular}{|c|c|c|c|c|c|c|c|c|c|c|c|c|c|c|c|c|c|c|}
\hline Oח⿻ & $\begin{array}{l}\text { Aboren } \\
\text {. }\end{array}$ & NR" & $\mathrm{Nir}$ & 6I & OR & $\mathbf{P A}$ & $\mathbf{P P}$ & PO & PR & $\mathbf{R} \mathbf{M}$ & $\mathbf{k} \mathbf{F}$ & $\mathbf{S A}$ & SiL & \$k & \$T & WV & Wt & $Y \mathbf{M}$ \\
\hline Atele Lisoratory & $\mathbf{A L}$ & 1,287 & $15 \%$ & $3 \% 7$ & 900 & 679 & 634 & 755 & 1,217 & 751 & 12 & 1,120 & T,B33 & $1,1+5$ & T, & 90 & 1,9 & ה \\
\hline Argoune, East & $\mathbf{A N}$ & $1,89 t$ & 1,815 & 571 & 584 & 385 & 1,058 & 428 & 822 & 419 & 1,017 & 1,324 & 2,148 & 892 & 2,180 & 577 & 1,505 & 1,849 \\
\hline Argonoc, Wea & $A W$ & 0 & 712 & 2,077 & 2,048 & 1,766 & 1,468 & 1,986 & 2,448 & 1,982 & 716 & 1,168 & 1,100 & 2,331 & 1,004 & 2,140 & 1,759 & 746 \\
\hline Baboock \& Whom & LY & 0 & 2,491 & $\mathbf{0}$ & 350 & 0 & $\mathbf{0}$ & $\mathbf{0}$ & $\theta$ & 0 & 0 & 0 & a & 455 & 0 & 0 & $\mathbf{0}$ & 2,459 \\
\hline Batele Columbus & BC & 1,906 & 2,078 & 399 & 412 & 477 & 1,168 & 84 & 546 & 214 & 1,283 & 1,454 & 2,472 & 720 & 2,524 & 372 & 1,625 & 2,112 \\
\hline Beich ANoinde & $\mathbf{B A}$ & 2,125 & 2229 & 586 & 563 & 696 & 1,387 & 265 & 3 & 175 & 1,500 & 1,673 & 2601 & 656 & 2,723 & 25 & 1,813 & 2,331 \\
\hline Broothowe: NL & BNA & 2,437 & 2,670 & 808 & 821 & 1,115 & 1,817 & 699 & 189 & 531 & 1,870 & 2,103 & $3,0,03$ & 897 & 3,035 & 492 & 2,192 & 2704 \\
\hline Fermilab (FNAL) & FL & 1,572 & $1+305$ & 603 & 636 & 417 & 1,064 & $\mathbf{4 0}$ & 854 & 451 & $1,00 \mathrm{~s}$ & 1,350 & 2,138 & 924 & 2,167 & 609 & 1,531 & 1,839 \\
\hline Fernald (FEMP & FE & 1,824 & 2,034 & 299 & 312 & 409 & 1,104 & 173 & 605 & 321 & 1,217 & 1,390 & 2,408 & 620 & 2,440 & 479 & 1,526 & 2,048 \\
\hline Hanfoed Site & tos & 599 & 1,128 & 2,493 & 2,464 & 2,182 & 2,804 & 2,402 & 2864 & 2,398 & 1,133 & 1584 & 894 & 2,727 & 916 & 2,556 & 2,175 & 1,162 \\
\hline INEL & $\mathbf{I N}$ & $\mathbf{0}$ & 712 & 2,077 & 2,048 & 1,766 & 1,468 & 1,986 & 2,448 & 1,982 & 716 & 1,168 & 1,100 & 2,331 & 1,004 & 2,140 & 1,759 & 746 \\
\hline [IRI & $\pi$ & 1,177 & 918 & 1,420 & 1,391 & 1,230 & 313 & 1,543 & 2,006 & 1,673 & 483 & 9 & 1,154 & 1,653 & 1,196 & 1,832 & 614 & $\$ 2$ \\
\hline Kansas Ciny Plam & $\mathbf{K C}$ & 1,325 & 1,428 & 752 & 723 & 441 & 600 & 730 & 1,192 & 860 & 631 & 886 & 1,890 & 997 & 1,939 & 1,018 & 1,067 & 1,462 \\
\hline Knolls Alomic & KA & 2,393 & 2,626 & 872 & 885 & 1,099 & 1.300 & 688 & 291 & 416 & 1,827 & 2,076 & 2,959 & 96.] & 2,979 & $3 \mathbf{4}$ & $2,26 \%$ & 2,660 \\
\hline Lahence Bertely & LB & 963 & 769 & 2,592 & 2,563 & 2,332 & 1,485 & 2,543 & 3,005 & 2,538 & 1,283 & 1,185 & 45 & 2,791 & 47 & 2,697 & 1,509 & 753 \\
\hline Latarence Lhermore & $\mathbf{L}$ & 972 & 678 & 2,551 & 2,523 & 2,327 & 1,445 & 2,552 & 3,014 & 2,547 & 1,292 & 1,145 & 0 & 2,750 & 64 & 2,706 & 1,468 & 712 \\
\hline Los Alamoo NL & LA & $t_{1}: 144$ & 997 & 1,509 & 1,480 & 1,319 & 402 & 1,632 & 2,004 & 1,762 & 452 & 102 & 1,326 & 1,742 & 1294 & $1, \$ 21$ & 693 & 1,031 \\
\hline Mound Plont & MP & $\mathbf{1}, 875$ & 2,047 & 335 & 348 & 41 & 1,137 & 152 & 614 & 292 & 1,250 & 1,432 & 2,441 & 656 & 2,473 & 440 & 1,561 & 2,081 \\
\hline Neval Reaciose Facility & NR & 0 & 712 & 2,077 & 2,048 & 1,766 & 1,468 & 1,986 & 2,448 & 1 \$ 382 & 716 & 1,168 & 1,300 & $2,3 \mathbf{1}$ & $t, 004$ & 2,140 & 1,759 & 746 \\
\hline Newde Tes Ste & NT & 0 & 0 & 2,180 & 2,151 & 1,864 & 1,200 & 2,158 & 2,620 & 2,214 & 836 & 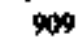 & $\mathbf{0}$ & 2,414 & 734 & 2,373 & 1,365 & 46 \\
\hline ORISE & 01 & 0 & $\mathbf{0}$ & o & 10 & 333 & 1,125 & 358 & 202 & 595 & 1,383 & $1,41 t$ & 2,551 & 369 & 2,584 & 753 & 1,410 & 2,214 \\
\hline Oat Ridye Recerr. & OR & 0 & $\mathbf{0}$ & 0 & 0 & 304 & $1,0 \% 6$ & $37 t$ & 715 & 608 & 1,354 & 1,382 & 2,523 & 379 & 2,584 & 766 & 1,381 & 2,185 \\
\hline Padmath GDP & $\mathbf{P A}$ & 0 & 0 & 0 & 0 & $\mathbf{0}$ & 940 & 0 & 1,009 & 687 & $1,0 m 2$ & 1,226 & 2,327 & 568 & 2,359 & 845 & 1,258 & $1,0,013$ \\
\hline Paniex Plam & $\mathbf{P P}$ & 0 & 0 & 0 & 0 & 6 & 0 & 1,248 & 1,710 & 1,378 & $M 4$ & 304 & 1,445 & 1,358 & 1,506 & 1,537 & 308 & 1,243 \\
\hline Porlsmouxh GDP & $\mathbf{P O}$ & 0 & 0 & 4 & 0 & 0 & 0 & 0 & 589 & 276 & $1, \mathbf{3 6 1}$ & 1,543 & 2,552 & 50 & 2,584 & 434 & 1,632 & 0 \\
\hline Princelon PPL & PR & 1) & $\mathbf{0}$ & 0 & 0 & v & 0 & 0 & 0 & 528 & 1,823 & 1,99 & 3,014 & 767 & 3,046 & 459 & 2,066 & 2,654 \\
\hline Reactive Metals & $\mathbf{R M}$ & $\mathbf{0}$ & 0 & (1) & 0 & 0 & 0 & 0 & 0 & $\mathbf{0}$ & 1,415 & 1,664 & 2,543 & 726 & 2,57 & 162 & 1,822 & 2218 \\
\hline Racisy Flata Plaat & RF & 0 & 0 & 0 & $\mathbf{0}$ & 0 & 0 & 0 & 0 & 0 & $\mathbf{0}$ & 474 & 1,292 & 1,618 & 1,324 & 1,573 & 1,067 & 868 \\
\hline SNL, Albuquerqoe & SA & 0 & 0 & 0 & 0 & 0 & 0 & 0 & 0 & 0 & 0 & 0 & 1,145 & 1,644 & 1,198 & 1,823 & $\cos$ & 943 \\
\hline SNL, Livermoce & SL & $\mathbf{0}$ & 0 & 0 & 0 & $\mathbf{0}$ & $\mathbf{0}$ & $\mathbf{0}$ & 0 & 0 & 0 & $\mathbf{0}$ & 0 & 2,750 & 64 & 2,706 & 1,468 & 712 \\
\hline Sorvazand Rivar & SR & $\mathbf{0}$ & 0 & D & 0 & $\mathbf{0}$ & 0 & $\mathbf{0}$ & $\theta$ & 0 & 0 & 0 & 0 & 0 & 2,820 & 1,023 & 1.524 & 2,448 \\
\hline SLAC & $\mathbf{s T}$ & 0 & 0 & 0 & 0 & t) & 0 & 0 & o & 0 & 0 & 0 & $\mathbf{0}$ & 0 & 0 & 2,738 & 1,529 & $m$ \\
\hline Wat Vally DP & WV & 0 & $\mathbf{0}$ & 0 & 0 & ; & 0 & $\mathbf{0}$ & $\mathbf{0}$ & 0 & 0 & 0 & 0 & 0 & $\mathbf{0}$ & o & 1,980 & 2,407 \\
\hline wIPs & w! & 0 & 0 & 0 & 0 & $\mathbf{0}$ & 0 & 0 & $\mathbf{0}$ & 0 & 0 & 0 & 0 & 0 & $\mathbf{0}$ & $\theta$ & 0 & 1,399 \\
\hline Yuces Mounlsin, NV & $\mathbf{Y M}$ & $\mathbf{0}$ & $\mathbf{0}$ & 0 & 0 & 0 & $\mathbf{0}$ & 0 & 0 & $\mathbf{0}$ & $\mathbf{0}$ & 0 & 0 & 0 & 0 & 0 & 0 & 0 \\
\hline
\end{tabular}


Table 2. Distance (in miles) by rail between DOE sites.

\begin{tabular}{|c|c|c|c|c|c|c|c|c|c|c|c|c|c|c|c|c|c|c|c|}
\hline & & $\mathbf{A L}$ & $\mathbf{A} \mathbf{N}$ & $A W$ & LY & $\overline{B C}$ & $\overline{\mathbf{B A}}$ & BN & FL & FE & HS & IN & Tit & KC & $\mathbf{R}$ & U: & 21 & 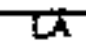 & $T h$ \\
\hline Amet Laboralory & $\mathbf{A L}$ & 0 & 3 & 1,242 & 0 & 700 & 823 & 1,365 & $2 \%$ & 717 & 1,788 & $1,2,2$ & 1,187 & $2 / 3$ & 7,126 & 1,873 & 2,015 & 1,124 & 75 \\
\hline Argonne, Esat & AN & 0 & 0 & 1,655 & 0 & 401 & 518 & 1,066 & 49 & 412 & 2,201 & 1,655 & 1,351 & 439 & 827 & 2,549 & 2,506 & 1,288 & 416 \\
\hline Argonne, Wey & AW & 0 & 0 & 0 & 0 & 1,942 & 2,133 & 2,607 & 1,533 & 1,907 & 658 & 0 & 1,247 & 1,238 & 2,468 & $1+102$ & 1,100 & 1,179 & 1,926 \\
\hline Babotect \& Wilock & LY & 0 & $\mathbf{0}$ & 0 & 0 & 0 & 0 & 0 & 0 & 0 & 2,879 & 2,333 & 0 & 0 & 0 & 0 & 0 & 0 & 0 \\
\hline Baicle Columbus & BC & 0 & 0 & 0 & 0 & 0 & 200 & es5 & 427 & 135 & 2,488 & 1,942 & 1,739 & 753 & 615 & 2579 & 2,718 & 1,696 & 65 \\
\hline Bentib Atowic & BA & 0 & 0 & 0 & 0 & 0 & & 312 & 543 & 475 & 2,611 & 2,133 & 1,857 & 943 & $5 \mathbf{3 3}$ & 2,696 & 2,840 & 1,794 & 345 \\
\hline Broolinower NL & BN & 0 & 0 & ) & $\mathbf{0}$ & 0 & 0 & $\mathbf{0}$ & 1,088 & 984 & 3,153 & 2,607 & 2,414 & $1,51 B$ & 239 & 3,238 & 3,383 & 2,351 & 920 \\
\hline Fermitob (FNAL) & $\mathbf{F L}$ & 0 & $\mathbf{0}$ & $\theta$ & 0 & 0 & 0 & 0 & 0 & 441 & 1,971 & 1,533 & 1,356 & 453 & 853 & 2,343 & 2,341 & 1,405 & 443 \\
\hline Femals (FEMP) & $\mathbf{F E}$ & $\theta$ & $\mathbf{0}$ & 0 & 0 & 0 & 0 & $\mathbf{0}$ & $\mathbf{0}$ & $\mathbf{0}$ & 2,505 & 1,907 & 1,751 & 717 & 745 & 2,590 & 2,735 & 1,608 & th \\
\hline Hlanford Site & HS & 0 & 0 & 0 & 0 & 0 & 0 & $\mathbf{0}$ & 0 & $\mathbf{0}$ & 0 & 658 & 1,793 & 1,784 & 2,914 & 986 & 975 & 1,725 & 2,472 \\
\hline JNEL & $\mathbf{D N}$ & $\mathbf{0}$ & $\mathbf{0}$ & $\mathbf{0}$ & 0 & 0 & 0 & 0 & 0 & 0 & 0 & 0 & 1,247 & 1,238 & 2,468 & 1,102 & 1,100 & 1,179 & 1,926 \\
\hline ITRI & $\mathbf{T T}$ & 0 & 0 & 0 & 0 & $\mathbf{0}$ & o & $\mathbf{0}$ & 0 & 0 & 0 & 0 & o & 932 & 2,177 & 1,266 & 1,222 & 104 & 1,767 \\
\hline Kansea Cly Pint & $\mathrm{KC}$ & 0 & 0 & 0 & 0 & 0 & 0 & 1) & 0 & 0 & 0 & 0 & 0 & 0 & 1,250 & 2016 & 2,013 & 869 & 708 \\
\hline Knolls Alomic & $\mathbf{K A}$ & 0 & 0 & 0 & 1) & b & 0 & 0 & 0 & 0 & 0 & 0 & 0 & 0 & $\mathbf{0}$ & 2,999 & 3,144 & 2,122 & 60 \\
\hline Lemexpertatey & LB & 0 & 0 & 0 & $\mathbf{0}$ & 0 & 0 & $\mathbf{0}$ & $\mathbf{0}$ & $\mathbf{0}$ & 0 & 0 & 0 & 0 & 0 & o & 46 & 1,354 & 2,717 \\
\hline Lonteace Liveritore & $\mathbf{L L}$ & $\mathbf{0}$ & 0 & $\mathbf{0}$ & 0 & $\mathbf{0}$ & 0 & $\mathbf{0}$ & 0 & $\mathbf{0}$ & 0 & 0 & 0 & 0 & 0 & 0 & $\mathbf{0}$ & 1,326 & 2,695 \\
\hline Los Alatos NL & $\mathbf{L A}$ & 0 & to & o & 0 & D & 0 & $\mathbf{0}$ & $\mathbf{0}$ & $\mathbf{0}$ & 0 & 0 & 0 & $\mathbf{0}$ & $\mathbf{0}$ & 0 & 0 & 0 & 1,704 \\
\hline Mound PlanI & MP & $\mathbf{0}$ & $\mathbf{0}$ & 0 & 0 & 0 & 0 & $\mathbf{0}$ & 0 & $\mathbf{0}$ & 0 & 0 & 0 & 0 & 0 & 0 & 0 & 0 & 0 \\
\hline Nund Reactors Facility & $\mathbf{N R}$ & $\mathbf{0}$ & 0 & 0 & 0 & a & 0 & 0 & 0 & $\mathbf{0}$ & 0 & 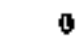 & 0 & 0 & 0 & $\mathbf{0}$ & $\mathbf{0}$ & 0 & 0 \\
\hline Novada Teat Site & NT & 0 & 0 & 0 & 0 & 0 & 0 & 0 & $\mathbf{0}$ & 0 & 0 & 0 & $\mathbf{0}$ & 0 & $\mathbf{0}$ & 0 & 0 & 0 & 0 \\
\hline ORISE & Or & 0 & 4 & 0 & $\mathbf{0}$ & 0 & $\mathbf{0}$ & $\mathbf{0}$ & $\mathbf{0}$ & $\mathbf{0}$ & 0 & 0 & 0 & $\mathbf{0}$ & $\mathbf{0}$ & $\mathbf{0}$ & $\mathbf{0}$ & $\mathbf{0}$ & 0 \\
\hline Oat Ruge Reserv. & OR & 0 & $\mathbf{0}$ & 0 & 0 & 0 & 0 & $\mathbf{0}$ & $\mathbf{0}$ & 0 & 0 & 0 & $\mathbf{0}$ & $\mathbf{0}$ & $\mathbf{0}$ & $\mathbf{0}$ & $\mathbf{0}$ & 0 & 0 \\
\hline Padecah GDP & $\mathbf{P A}$ & 0 & 0 & 0 & 0 & 0 & 0 & 0 & 0 & 0 & 0 & 0 & $\mathbf{0}$ & $\mathbf{0}$ & $\mathbf{0}$ & 0 & 0 & 0 & 0 \\
\hline Panter Plant & PP & 0 & $\mathbf{0}$ & 0 & 0 & 0 & 0 & 0 & $\mathbf{0}$ & 0 & 0 & 0 & 0 & 0 & $\mathbf{0}$ & $\mathbf{0}$ & 0 & 0 & d) \\
\hline Portt:moluth GDP & PO & 0 & $\mathbf{0}$ & 4 & 0 & 0 & 0 & 0 & 0 & 0 & 0 & $\rightarrow$ & 1) & 0 & 0 & ( & t & 0 & 0 \\
\hline Princetou PPL & PR & 0 & 0 & 0 & 0 & 0 & 0 & 0 & 0 & 0 & 0 & 0 & 0 & 0 & 0 & a & 0 & o & $\mathbf{0}$ \\
\hline Reactive Metala & RA & 0 & $\mathbf{0}$ & ) & 0 & 0 & 0 & $\mathbf{0}$ & $\mathbf{0}$ & $\mathbf{0}$ & 0 & 0 & $\mathbf{0}$ & 0 & $\mathbf{0}$ & 0 & 0 & $\mathbf{0}$ & 0 \\
\hline Rocky Fi:ts Plant & RF & 0 & 0 & 0 & 0 & 0 & o & 1) & 0 & 0 & 0 & 0 & 0 & 0 & 0 & 0 & 0 & 0 & 0 \\
\hline SNM, Albuquerque & SA & 0 & $\mathbf{0}$ & 0 & 0 & 0 & o & $\mathbf{0}$ & 0 & $\mathbf{0}$ & 0 & 0 & 0 & 0 & 0 & $\mathbf{0}$ & $\mathbf{0}$ & 0 & 0 \\
\hline \$NL L Lermore & SL & $\mathbf{0}$ & $\mathbf{0}$ & 0 & $\mathbf{0}$ & 0 & $\mathbf{0}$ & 0 & $\mathbf{0}$ & $\mathbf{0}$ & 0 & 0 & $\mathbf{0}$ & $\mathbf{0}$ & $\mathbf{0}$ & $\mathbf{0}$ & $\mathbf{0}$ & 0 & 0 \\
\hline Sevannati River & SR & $\mathbf{0}$ & 0 & 0 & 0 & 0 & 0 & 0 & 0 & 0 & 0 & 0 & 0 & 0 & 0 & 0 & A & 0 & 0 \\
\hline SLAC & $\$ \mathbf{T}$ & 0 & 0 & 0 & 0 & 0 & 0 & 0 & 0 & 0 & 0 & 0 & 0 & 0 & 0 & 0 & 0 & 0 & 0 \\
\hline West Vallog DP & WV & 0 & 0 & $\mathbf{0}$ & 0 & $\mathbf{0}$ & 0 & $\mathbf{0}$ & 0 & $\mathbf{0}$ & 0 & 0 & 0 & 9 & 0 & $\mathbf{0}$ & $\mathbf{0}$ & 0 & 0 \\
\hline WIPP & w] & 0 & 0 & 0 & 0 & 0 & 0 & 0 & 0 & 0 & 0 & 0 & 0 & 0 & 0 & 0 & 0 & 0 & 0 \\
\hline Yucea Mountain, NV & YM & 0 & 0 & 0 & 0 & 0 & 0 & 0 & 0 & 0 & 0 & 0 & $\mathbf{0}$ & 0 & 0 & $\mathbf{0}$ & 0 & 0 & 0 \\
\hline
\end{tabular}


Table 2. (Cont'd)

\begin{tabular}{|c|c|c|c|c|c|c|c|c|c|c|c|c|c|c|c|c|c|c|}
\hline & & $\mathrm{NR}$ & Nis & or & OR & $\mathbf{H A}$ & $\mathrm{Pr}$ & ro & Pk & $\mathbf{R T}$ & k & $3 A$ & SL & $\mathbf{S k}$ & sil & $w v$ & WL & $\overline{\mathbf{M M}}$ \\
\hline Alpes Lobxckichy & AL & 1,22 & 1,674 & $\% 6$ & 54 & 646 & 819 & 724 & 1,197 & 715 & $7 i 3 z$ & 1,IST & 2018 & 1,281 & 1,924 & 7831 & 1,IIS & 1,674 \\
\hline Argone, Eart & $A N$ & 1,655 & 2,348 & 651 & 649 & 390 & 972 & 422 & $8 \%$ & 418 & 1,194 & 1,351 & 2506 & 976 & 2536 & 579 & 1,279 & 2,348 \\
\hline Argonne, Won & $A W$ & 0 & 756 & 2,099 & 2,055 & 1,699 & 1,141 & 1,975 & 2,507 & 2,060 & 738 & $1,2 n$ & 1,100 & 2,407 & 1,160 & 2123 & $t, 447$ & 756 \\
\hline Bnboock \& Wileck & EY & 0 & 2,765 & 0 & 386 & $\mathbf{0}$ & o & 0 & 0 & 0 & $\theta$ & 0 & 0 & 661 & 0 & 0 & 0 & \\
\hline Balelle Colinbur & BC & t,902 & 2,374 & 366 & 39 & 581 & 1,381 & 91 & 655 & 207 & 1,502 & 1,759 & $2,7 t 8$ & 700 & $2,4 n$ & 370 & 1,688 & 2,374 \\
\hline Bettis Awomic & BA & 2,133 & 2,40 & 714 & 900 & 916 & 1,479 & 429 & 400 & 136 & 1,692 & 1857 & 2800 & 947 & 2,746 & 24 & 1,785 & 2,496 \\
\hline Broothrwen NL & 自N & 2,607 & 3,039 & 1,221 & 1,152 & 1,346 & 2,035 & 921 & 410 & 648 & 2,266 & 2,4t4 & 3,383 & 1,239 & 3,289 & 549 & 2,342 & 3,0099 \\
\hline Fermilab (FNAL) & $\mathbf{F L}$ & 0,533 & 1,997 & 679 & 682 & 469 & 97 & 451 & 924 & 445 & $1,0] 6$ & 1,356 & 2341 & 1,001 & 2,393 & 603 & 1,284 & 1,997 \\
\hline Ferneld (FEM) & FE & 1,907 & 2,391 & 331 & 368 & $\mathbf{4 6 9}$ & 1,373 & 207 & 938 & 337 & 1,466 & 1,151 & 2,735 & 774 & 2,641 & 631 & 1,679 & 2,391 \\
\hline Henford site & HS & 658 & 1,302 & 2,644 & 2,601 & 2,245 & $1,6 B 6$ & 2,515 & 2,985 & 2,505 & 1,234 & 1,793 & 973 & 2,953 & 1,036 & 2,669 & 1,993 & 1,302 \\
\hline INEL & $\mathbf{J N}$ & 0 & 756 & 20,9 & 2005 & 1,699 & J, 14$]$ & 1,975 & 2507 & 2,060 & 788 & 1,247 & 1,100 & 2,407 & 1,160 & 2,123 & 1,447 & 756 \\
\hline ITRI & $\mathbf{I T}$ & $1,2 \pi 7$ & 1,065 & 1,309 & 1,749 & 1,539 & 379 & 1,761 & 2,248 & 1,769 & 572 & 0 & $1,2,2$ & 2,3ts & 1,253 & 1,929 & 477 & 1,063 \\
\hline Kantats City Plmat & $\mathbf{K C}$ & 1,238 & 1,670 & 881 & 839 & 482 & $\$ 54$ & 758 & 1,299 & $\mathbf{8 4 2}$ & 778 & 932 & 2,013 & 1,161 & 2,073 & 1,033 & B61 & 1,670 \\
\hline Knoll Atomic & $K_{A}$ & 2,468 & 2,800 & 981 & 957 & 1,106 & 1,807 & 6 & 214 & 408 & 2,027 & 2,17 & 3,144 & 1,044 & 3,050 & 309 & 2,114 & 2,900 \\
\hline Lawnence Berkeky & LB & 1,102 & 860 & 2,890 & 2,686 & 2,490 & 1,361 & 2,767 & 3,298 & 2,851 & 1,320 & 1,266 & 46 & 3,192 & 56 & 2,773 & 1,660 & 860 \\
\hline Lempence Llverupere & LLt & 1100 & 1,370 & 2,868 & 2,831 & 2,469 & 1,534 & 2,745 & 3,276 & 2,829 & 1,394 & 1,222 & o & 3,183 & 60 & 2,858 & 1,633 & 1,370 \\
\hline Lo Alamos NL & LA & 1,179 & 1,169 & 1,926 & 1,686 & 1,476 & 483 & $1,6 \%$ & 2,186 & 1,706 & S04 & 104 & 1,326 & 2,252 & 1,357 & 1,866 & $58 t$ & 1,169 \\
\hline Mound Plam & $\mathbf{M P}$ & 1,926 & 2,386 & 301 & 328 & 564 & 1,396 & 156 & 719 & 272 & 1,485 & 1,767 & 2,695 & 74 & 2,930 & 562 & $t, 703$ & 2,386 \\
\hline Naval Reactoc Fac. & $\mathbf{N R}$ & o & 756 & 2,099 & 2,055 & 1,699 & 1,141 & 1,975 & 2,507 & 2,060 & 738 & 1,247 & 1,100 & 2,407 & 1,160 & 2,123 & 1,477 & 756 \\
\hline Nerada Teat Sile & NT & $\mathbf{0}$ & $\mathbf{0}$ & 2,530 & 2,487 & 2,131 & 1,376 & 2401 & 2871 & 2,391 & 987 & 1,065 & 1,370 & 2,839 & 862 & 2,554 & 1,475 & $\mathbf{0}$ \\
\hline ORISE & OI & 0 & 0 & 0 & 40 & 632 & 1,611 & 392 & 1,176 & 575 & 1,658 & 1,969 & 2868 & 443 & 3,103 & 198 & I,918 & 2,530 \\
\hline Oak Ridge Rexry. & OR & 0 & 0 & 0 & $\mathbf{0}$ & 527 & 1,371 & 442 & 760 & 600 & 1,586 & 1,748 & 2.831 & 417 & $3,03]$ & s\$s & $1,67 \mathrm{~s}$ & 2,487 \\
\hline Paducah GDP & PA & 0 & $\mathbf{0}$ & 0 & 0 & $\mathbf{0}$ & 1,103 & 495 & 1,145 & $6 \%$ & 1,220 & 1,539 & 2,469 & 714 & 2,597 & B6t & 1,410 & 2,131 \\
\hline Pomex Plant & PP & 0 & 0 & $\mathbf{0}$ & $\mathbf{0}$ & $\mathbf{0}$ & 0 & 1,382 & 1,867 & 1,387 & 465 & 379 & 1,534 & 1,937 & 1,564 & 1,551 & 307 & 1,376 \\
\hline Portsmoth GDP & PO & $\mathbf{0}$ & $\mathbf{0}$ & 0 & o & 0 & $\mathbf{0}$ & - & 858 & 279 & 1,535 & 1,361 & 2,745 & 655 & 2,65] & $\$ 85$ & 1,689 & 2,401 \\
\hline Princelon PPL & PR & $\mathbf{0}$ & 0 & 0 & 0 & 0 & 0 & 0 & 0 & 511 & 2,466 & 2,249 & 3,276 & 848 & 3,121 & 126 & 2,185 & 2,871 \\
\hline Reatitus Metald & FM & 0 & 0 & 0 & 0 & 0 & o & 0 & 0 & 0 & 1,619 & 1,769 & 2,829 & 920 & 2,641 & 163 & 1,705 & 2,391 \\
\hline Rocky Flatu Plamt & RF & 0 & $\mathbf{0}$ & $\mathbf{0}$ & 0 & $\mathbf{0}$ & 0 & 0 & 0 & 0 & 0 & 572 & 1,794 & 1,938 & 1,377 & 1,782 & 769 & 987 \\
\hline SNL, Albuquerque & SA & 0 & $\mathbf{0}$ & $\mathbf{0}$ & $\mathbf{0}$ & $\mathbf{0}$ & 0 & 0 & 0 & 0 & $\mathbf{0}$ & o & 1,222 & 2,315 & 1,253 & 1,929 & $m$ & 1,065 \\
\hline SNL, Lvermore & SL & 0 & $\mathbf{0}$ & 0 & 0 & 0 & 0 & $\theta$ & 0 & $\mathbf{0}$ & 0 & 0 & 0 & 3,183 & 60 & 2,898 & 1,633 & 1,370 \\
\hline Savianah River & SR & 0 & 0 & 0 & o & 0 & 0 & $\theta$ & 0 & 0 & 0 & 0 & 0 & 0 & 3,194 & 1,223 & 2,243 & $2, B, 9$ \\
\hline SLAC & $\mathbf{S T}$ & 0 & 0 & $\mathbf{0}$ & 0 & ( & 0 & 0 & 0 & 0 & 0 & o & 0 & $\theta$ & 0 & 28) & 1,662 & 862 \\
\hline Wead Valley DP & wV & 0 & $\mathbf{0}$ & $\mathbf{0}$ & 0 & $\mathbf{0}$ & 0 & 0 & 0 & 0 & 0 & 0 & 4 & 0 & 0 & $\mathbf{0}$ & 1,858 & 2,540 \\
\hline WIPP & $w \mid$ & 0 & o & 0 & 0 & 0 & 0 & 0 & 0 & 0 & 0 & 0 & 0 & 0 & $\theta$ & 0 & 0 & $1+475$ \\
\hline Yuan Mountale, & $\mathbf{Y M}$ & 0 & 0 & 0 & 0 & $\mathbf{0}$ & 0 & 0 & 0 & $\mathbf{0}$ & 0 & 0 & 0 & 0 & 0 & $\mathbf{0}$ & $\mathbf{0}$ & \\
\hline
\end{tabular}




\section{LLW, MLLW, ALPHA LLW, ALPHA MLLW, AND GTCC/DOE EQUIVALENT WASTE}

Transportation of LLW, MLLW, alpha LLW, and alpha MLLW can involve either contacthandled or remote-handled shipments. However, a large portion of the GTCCDOE equivalent waste will involve only remote-handled shipments. A sunimary of costs associated with shipment of waste by truck is presented below.

\subsection{Contact-Handled Waste}

\subsubsection{Truck Shipmant}

Transportation costs for contact-handled LLW, MLLW, and alpha LLW and alpha MLLW are estimated based on the assumption tbat unshiekded 48-ft-tong truck trailers containing eighty-eight $500-1 \mathrm{~b}$ drums are used, yielding a total of $44,000 \mathrm{lb}$ per shipment. The total transportation costs can be cakulated using the following steps:

a. If the average weight of the dnums is $\mathbf{5 0 0 ~} \mathrm{lb}$ or more, divide the total weight of waste (in lb) by 44,000 lbtshipment to obtain the number of shipments. If the average weight of the drums is less than $500 \mathrm{lb}$, divide the total volume of wastc by $640 \mathrm{ft}^{3}$ ( 88 drums at $7.3 \mathrm{ft}^{3} /$ drum) to obtain the number of shipmerits.

b. Multiply the CPLM unit rates listed below by the one-way distance (in miles) and the number of shipments (from step a above) to obtain the CPLM cost.

- Less than 30 miles: $\quad \$ 5.94 / m i l e$

- 30-200 miles: $\quad \$ 4.98 /$ mile

- More than 200 miles: $\$ 4.00 / m i l e$.

c. Multiply the number of shipments (from step a above) by $\$ 830$ per shipment to obtain the foxed transportation costs.

d. Add the CPLM cost (from step b above) to the fixed cost (from step $c$ above) to obtain the total transportation cost.

\subsection{Pal Shipment}

Transportation costs by rail for contact-handled LLW and MLLW are estimated based on the assumption that waste in drums or steel boxes would be moved in 40 -ft-long intermodal (sealand) containers. These containers can be moved by truck or on rail flatcars. Each container would bold seventy-six 500 -tb drums, yielding a total weight of $38,000 \mathrm{lb}$, or would hold eleven $3,945-1 \mathrm{~b}$ boxes, yielding a total weight of about $\$ 4,000 \mathrm{Jb}$. The total transportation costs can be calculated using the following steps:

a. Divide the total weight of waste (in lb) by $38,000 \mathrm{lb}$ (for drums) or $44,000 \mathrm{lb}$ (for boxes) to obtain the number of container loads. 
b. Multiply the CPLM unit rates listed below by the one-way distance (in miles) and by the number of container loads (from step a above) to obtain the CPLM

- 500 to 1,000 miles: $\$ 2,32$ /mile.

- 1,000 to 2,000 miles: $\quad \$ 1,91$ mite

- More than 2,000 miles: $\$ 1.60$ /mile

c. Multiply the number of container loads (from step a above) by $\$ 750$ per container bad to obtain the fixed transportation costs.

d. Add the CPLM (from step b above) to the fixed cost (from step c above) to obtain the total transportation cost.

The cost estimate was prepared on a per-container basis; the number of containers per flat car will vary by railroad carrier. One can assume three containers per flat car, with an average capacity of 20 tons per container.

\subsection{Remote-Handled Waste}

Transportation costs by tuck for remote-handled LLW, MLLW, alpha LLW, and alpha MLLW, and GTCCIDOE equiralent waste are estimated based on a payload of $13,400 \mathrm{lb}$ per shipment. Typically fourteen 55-gallon drums are badex per shipment. The total transportation cost for a given scenario can be developed according to the following steps:

a. Divide the total weight of waste by $13,400 \mathrm{lb}$ to obtain the number of shipments.

b. Multiply the CPLM unit rates listed below by the one-way distance (in miles) and the number of shipments (from step a above) to obtain the CPLM cost.

- Less than 30 miles: $\quad \$ 11.70 /$ mile

- 30-200 miles: $\quad \$ 7.85 /$ mile

- More than 200 miles: $\$ 4.90 /$ mile.

c. Multiply the number of shipments (from step b above) by $\$ 2,480$ per shipment to obiain the fined transportation costs.

d. Add the CPLM costs (from step b above) to the fixed cost (from step C above) to obtain the total transportation cost.

a. The volume of remote-handled waste of this type is very small and does not warrant an estimate of rail costs in addition to truck costs. Also, the standard remote-handled containers are not designed for rail shipment. 


\subsection{Guldelines for Liquid Waste Shipments by Truck or Rail}

Packaging specifications for radiaactive waste shipments are found in the newly revised 49 CFR 173.401 (Subpart I). Liquid shipments of contact-handled LLW, MLLW, alpha LLW, alpha MLLW, and GTCC waste normally can be shipped in Type $A$ containers. These shipments have to be evaluated by formulas given in 49 CFR 173.433 to determine whether the source material activity is lower than the linits given in 49 CFR 173.435 (see $A_{1}$ and $A_{2}$ values). Generally, sthipments of liquid LLW and MLLW will qualify as low-specific-activity shipments. Thus, these shipments can be packaged in Type A containers. For shipments with $A$ values (Curies) in excess of the limits given in 49 CFR 173.435, the shipper must use Type B containers.

Shippers of liquids in Type A containers can use the CPLM rates given in Section 2.1 for contact-handled waste with the following changes to Section 2.1. Liquid shipments differ from solid shipments because of the meed to provide secondary containment of spills that might oceur in transit (shippers must provide a 2:1 ratio of containment wolume to liquid volume). The level of activity will define the packaging combinations. Some very low-specific-activity shipments may not require secondary containment; however, secondary containment is highly recommended for all shipments. The cost information for liquid shipments assumes eighty-eight drums per trackload, but the hquid component will only be $50 \%$ of the shipment volume. The total quantity of liquid per shipment is estimated to be 2,600 gal. The shipper should divide the total quantity of liquid to be shipped by 2,600 gal to determine the number of shipments. A common method used for packaging liquids is to place the liquid waste in a 30-gal closed-top drum and place this drum in a 55-gal open-head drum. Absorbent is placed between the two containers.

Shippers of liquikts in Type B containers can use the CPLM rates given in Section 22 for remote-handled waste. The number of shipments can be determined by dividing the quantity of liquid to ship by $3,300 \mathrm{lb}$. Fourteen drums with 30 gal per drum equals 420 gallons, times $8 \mathrm{lb} / g a l$ equals approximately $3,300 \mathrm{lb}$ per shipment.

\subsection{Guidelines for Lab Pack Shipments}

Laboratory chemicals, or sample vials, may be packaged in drums as "lab packs." This type of shipment typically contain small quantities of liquids. To provide secondary containment, the shipper places absorbent in the bottom of the drum and adds the vials in a layer, repeating this procedure until the drum is full. Costs for this type of shipment can be estimated using the procedure given in Section 2.1 with one exception. Assume lab packs weigh $50 \%$ kess than solid waste drums. Up to ninety-six drums of lab packs can be shipped per truckload, which equak 24,000 lb per shipment. 


\section{TRANSURANIC WASTE}

This section presents cost for shipment of transuranic waste by truck and rait. The TRUPACT-II containers represent the standard packaging for contact-handled waste shipped by truck or rail. The TRUPACT-Il is designed for use in DOE's Waste Isolation Pilot Plant (WIPP) in New Mexico. Remote-handled TRU waste can be shipped in a variety of Type B configurations. The specific activity of the waste must be known by the shipper in order to select the appropriate packaging. ${ }^{b}$ Costs for contact-handled and remote-handled shipments are presented below.

\subsection{Truck Shipment of Contect-Handled Waste}

Transportation costs for contact-handled TRU waste are based on using TRUPACT-II overpacks. Each overpack handles fourteen 55-gal drums with a total maximum payload per container of $7,265 \mathrm{~kb}$. Three TRUPACT-II overpacks may be shipped per truckload. The total transportation cost can be calculated by the following steps:

a. Divide the total weight of waste by $7,200 \mathrm{lb}$ to obtain the number of overpacks needed. Divide this number by 3 to obtain the number of truck shipments.

b. Multiply the below listed CPLM unit rates by the one-way distance (in miles) and the number of shipments (from step a above) to obtain the CPLM cost.

- Less than 200 miles: $\quad \$ 19.65 /$ mile

- 200 to 1,000 miles: $\quad \$ 10.87 /$ mile

- 1,000 to 2,500 miles: $\$ 9.31 /$ mile.

c. The fixed costs are obtained by multiplying the number of truck shipments by $\$ \$, 630$.

d. Add the CPLM (from step b above) to the fixed cost (from step $c$ above) to obtain the total transportation cost.

\subsection{Truck Shlpment of Remote-Handled TRU Waste}

Remote-handled TRU waste may come in different forms. The different waste forms will require various combinations of inner and outer packaging. Two cast estimates are prowided bekw. The shipper is advised to use the first estimate for materials suitable for packaging in drums or boxes and then placed in Type B casks. The second estimate is for high-kvel waste produced from a vitrification proxess.

b. In practice, TRUPACT II loading may be driven by criticality and thermal considerations at some sites. For instance, some planned TRU shipments from the Rocky Flats Plant are limited to half the container capacity due to these considerations. Shippers should ise their knowledge of the waste characteristies to refine the shipping capacity estimate. 
Chem-Nuclear and NuPac have an overweight truck cask (Type B) that has been used for truck shipments of remote-handled TRU waste. The overweight truck cask has a net payload capacity of $10,000 \mathrm{Jb}$. Total transportation cost can be calculated by the following steps:

a. Divide the weight of waste by $10,000 \mathrm{lb}$ to obtain the number of truck shipments.

b. Multiply the CPLM unit rates listed below by the one-way distance (in miles) and the number of shipments (from step a abowe) to obtain the CPLM cost.

- Less than 200 miles: $\quad \$ 19.65 /$ mile

- 200 to 1,000 miles: $\quad \$ 10.87 /$ mitle

- 1,000 to 2,500 miles: $\$ 9.31 /$ mile

c. Fixed costs are obtained by multiplying the number of truck shipments by $\$ 4,630$.

d. Add the CPLM (from step b abowe) to the fired cost (from step c above) to obtain the total transportation cost.

A waste stream similar to RH-TRU is high level waste (HLW) generated from defense operations. HLW has risk characteristics similar to RH-TRU. DOE has provided a cost estimate for shipping HLW by truck to Yucca Mountain for disposal. The CPLM is given as $\mathbf{\$ 1 3 . 7 0}$ for HLW, which includes variable and fired cost components. This information is provided to shippers for comparison purposes. More information about HLW is provided in Appendix F.

\subsection{Rall Shipment of Contact-Handled TRU Waste}

The user can assume that six TRUPACT-II owerpacks, which are designed for the Waste Isolation Pikt Plant (WIPP), can be loaded on a railroad flatcar. If drums are shipped, assume each drum weighs $500 \mathrm{lb}$ and 14 are placed in each TRUPACT-II overpack, for a total weight of 7,000 lb per overpack. Therefore, the total weight per rail car for drums is 42,000 lb. If the waste is packaged in bins rather than drums, assume each bin weighs $4,000 \mathrm{lb}$ and two bins are placed in cach overpack, yielding a total weight per rail car of $48,000 \mathrm{lb}$. The total transportation costs can be calculated using the following steps:

a. Divide the total mass of waste to be shipped by $7,200 \mathrm{lb}$ to obtain the number of TRUPACTs needed. Divide this number by 6 to obtain the number of rail cars needed. The cost presented below assumes one rait car per shipment.

b. Multiply the CPLM unit rates listed below by the one-way distance (in mikes) and by the number of container loads (from step a above) to obtain the CPLM.

- 200 to 500 miles: $\quad \$ 42.05 /$ mile

- $\quad \$ 00$ to 1,000 miles: $\quad \$ 33.9 \$ /$ mik

- $\quad 1,000$ to 2,500 miles: $\quad \$ 24,04 /$ mile 
c. Multiply the number of rail car shipments (from step A above) by $\$ 9,260$ per shipment to obtain the fixed transportation costs.

d. Add the CPLM (from step b abowe) to the fixed cost (from step c above) to obtain the cotal transportation cost.

\subsection{Rall Shlpments of Remote-Handled TRU Waste}

Remote-handled TRU waste can be shipped by rail. Only a few shipping containers exist for this application. The DOE has commissioned designs of equipment, such as the NuPac 72B cask, which is suitable for truck or rail shipment; bowever, this cask has not yet been constructed. The only known shipment of remote-handled TRU waste by rail was from the damaged reactor at Three Mile Island to the INEL. Detaik on the cost of this shipping campaign are provided in Appendix A-1.2. 


\section{SPENT NUCLEAR FUEL}

The cost-estimating procedure for SNF is presented below.

\subsection{Truck Shipment of SNF}

Transportation cost data for truck shipment of SNF casks are based on quotations from privatesector firms. These casts are generally used for shipment of SNF from nuclear power plants.

\subsubsection{Mothod for Eatimating Truck Shipment Costs}

The total transportation cost for a given scenario can be calculated as follows:

a. Determine the number of canisters needed to package the SNF assemblies or elements (see Table 3). For trucks, the number of canisters is the same as the number of shipanents.

b. Muttiply the CPLM unit rates listed below by the one-way distance (in miles) and the number of shipments (from step a above) to obtain the CPLM cost.

- Below 200 miles: $\$ 47.82 /$ mile

- 200 to 1,000 miles: $\quad \$ 16.70 /$ mile

* $\quad 1,000$ to 2,500 miles: $\$ 14.37 /$ mile.

c. Muttiply the number of shipments (from step a above) by $\$ 8,110$ per shipment to obtain transportation fixed costs.

d. Add the CPLM cost (from step b above) to the fixed cost (from step $\mathrm{c}$ above) to obtain the total Iransportation cost

\subsubsection{Quidance for Determining Number of Truck Shipments}

The number of assemblies that can be housed in each cask is known for common fuels such as boiling and pressurized water reactor fuel. However, determining the number of assemblies per cask for nonstandard fuel is a relatively complex process and detailed evaluations will be required. ${ }^{c}$ To facilitate the planning life-cycle cost ( $P L C C)$ estinating process, guidance based on several simplifying assumptions is presented below.

c. For odd-shaped fuels (e.g., the special SNF at INEL and the N-reactor fuel at Hanford Site), detailed geometry, physical, and radiological characteristics must be known. Before actual SNF shipments begin, a detajled evaluation will be required to ensure that the sbipment of the fuel meets the limilation of the NRC license for the cask. Based on this evaluation, special canisters or baskets may have to be provided to secure the fuel in the cask cavity and to facifitate criticality safety during normal and accident conditions. 
Table 3. Capacity of various cast and canister combinations for transport of N-reactor, high-enriched uranium, and low-entiched uranium fuel by truck.

\begin{tabular}{|c|c|c|c|c|c|c|c|}
\hline Cask & $\begin{array}{c}\text { Net } \\
\text { payload } \\
\text { (1b) }\end{array}$ & $\begin{array}{c}\text { Fuel } \\
\text { category }\end{array}$ & $\begin{array}{l}\text { Canister } \\
\text { size } \\
\left.\text { (in } \sqrt{ } 6^{-1}\right)\end{array}$ & $\begin{array}{l}\text { Cavity } \\
\text { dimension } \\
\text { (in.) }\end{array}$ & $\begin{array}{l}\text { Cans } \\
\text { per } \\
\text { cask }\end{array}$ & $\begin{array}{l}\text { Assem. } \\
\text { per } \\
\text { canister }\end{array}$ & $\begin{array}{c}\text { Total } \\
\text { assem. } \\
\text { per cask }\end{array}$ \\
\hline FSV-1 & 3,700 & $\begin{array}{l}\text { FSV } \\
\text { N-reactor }\end{array}$ & $\begin{array}{l}18 \times 187 / 3,225 \\
10 \times 187 / 1,750\end{array}$ & $\begin{array}{l}18 \times 192 \\
18 \times 192\end{array}$ & 1 & $\begin{array}{c}6 \\
42\end{array}$ & $\begin{array}{l}6 \\
42\end{array}$ \\
\hline NAC-LTW & 2,000 & $\begin{array}{l}\text { HEU } \\
\text { LEU } \\
\text { N-reactor }\end{array}$ & $\begin{array}{l}\text { Basket } \\
\text { Basket } \\
8 \times 120,900\end{array}$ & $\begin{array}{l}13.4 \times 180.9 \\
13.4 \times 180.9 \\
13.4 \times 180.9\end{array}$ & $\begin{array}{l}1 \\
1 \\
1\end{array}$ & $\begin{array}{c}1 \\
1-2 \\
40\end{array}$ & $\begin{array}{c}1 \\
1-2 \\
40\end{array}$ \\
\hline BM1-1 & 1,200 & $\begin{array}{l}\text { Research } \\
\text { fuel }\end{array}$ & $14.75 \times 51.5 / 870$ & $15.5 \times 54$ & 1 & $1-2$ & $1-2$ \\
\hline$G A-49$ & 5,000 & $\begin{array}{l}\text { PWR } \\
\text { BWR }\end{array}$ & $\begin{array}{l}\text { Basket } \\
\text { Basket }\end{array}$ & $\begin{array}{l}18 \times 187 \text { est. } \\
18 \times 187 \text { est. }\end{array}$ & 1 & $\begin{array}{l}4 \\
9\end{array}$ & $\begin{array}{l}4 \\
9\end{array}$ \\
\hline
\end{tabular}

a. Empty weight of canister shell, axsuming canisters are !-in. thick.

\subsubsection{High-Enwhehod Uranium (HEU) SNF.}

Four factors must be determined to develop the number of truck shipments. Guidelines for developing these factors are discussed below.

Canister aize. Table 3 contains a listing of the canisters that are currently in use or proposed for canning SNF. If limited data are available on the fuel geometry and criticality speciffications, a canister with a diameter ranging in size from 8 to 12 in. may be assumed for HEU fuel. Long HEU assemblies will not fit into the 120-in.-long canister originally proposed in the EGG-WM-10670 report. It is simpler to use a longer canister than to cut these assemblies for transportation purposes. Longer canisters may readily be used because the maximum available cavity length in a truck cask is 192 in.

Number of canisters per cart In most cases, the shipment will be limited to one canister per cast. However, several types of HEU fuel already exist in short canisters (i.e, less than $5 \mathrm{ft}$ long). These may be loaded end-to-end within the cask cavity.

Number of fuel elements or asemblies per canister. Three limiting factors determine the number of fuel elements or assemblies that can be placed in a canister: the heat generation rate of the total fuel in the shipment must not exceed the specified heat removal capacity of the cask; the weight must not exceed the cask payload capacity; and the total $U_{235}$ content in each canister must not exceed $40 \mathrm{~kg}$.

Shicting. The cask must provide adequate radiation protection as measured on the outer surface of the cask. Maximum dose rate at the package surface should be below the $200 \mathrm{mrem} / \mathrm{hr}$ regulatory limit, and the maximum dose rate at $2 \mathrm{~m}$ (6 ft) from the package should not exceed the limit of 10 mirem/hr. 


\subsubsection{Low Enriched Uranitum SNF.}

The number of truck cast shipmenss for low enriched uranium (LEU) fuel can be determined in the same manner as the HEU, except that canisters are not restricted to the $40 \mathrm{~kg}$ of $\mathrm{U}_{233}$ limitation.

\subsubsection{Other Special Cases.}

The recommended shipping methodology for special cases is stated below.

TRIGA SNF. TRIGA can be shipped in a BMI-1 cask, which has a basket specifically designed for TRIGA fuel. DOE currently owns this cask and lends it to universities to ship research fuels. It has a flexible design that inciudes eight licensed basket and canister combinations. TRIGA fuel is rod shaped; typically 1.5 in. in diameter by 21 in. long. Some of the TRIGA Euel currently in storage may be in long canisters with multiple rods per canister. TRIGA fuel has three basic levels of enrichment: $19.8 \%$ (the majority of the fuel), $70 \%$, and $93 \%$.

N-reactor SNF. Rod-shaped N-reactor fuel is about 2.5 in. in diameter by 21 in. long. The average weight of each element is $\mathbf{4 0} \mathrm{lb}$. To develop an estimate of truck shipment costs, assume transport by a $10 \times 180$-in. canister containing 42 elements.

Fort St. Vrain SNF. One-third of this high-temperature graphite reactor fuel has been shipped from Colorado to the INEL. These shipments were made using the FSV-1 truck cask manufactured by General Atomics. There are typically six assembies per canister, and one canister per cask in each shipment. The canisters used for these shipments are $100 \mathrm{long}$ to ship by rail.

\subsection{Rail Shipment of SNF}

Table 4 summarizes the casks that are either currently licensed or being considered for rail shipment of SNF. Two of the rail casks, the Navy's M-140 and Pacific Nuclear's IF-300, have been licensed and are currently in use. Two other rail casłs have not yet been licensed: Babcock \& Wilcox BR-100 and the multi-purpose canister (MPC) proposed by DOE's Office of Civilian Radioactive Waste Management for use at the monitored retrievable storage facility. General information and 1993 cost data for the M-140 cask is presented in Appendix E. Cost data for rail casts may be obtained from publicly available literature (TRW 1993a and 1993b) or estimated from this study.

\subsubsection{Wethod for Esthnating Rall Shlpment Costo}

To determine the cost of an SNF rait shipment, first determine the type of cask to be employed. The IF.300 is suiled for facilities with 70-ton itt capacities, and the M-140 is suited for facilities with 100-ton lift capacities. The total transportation costs for a given scenario then can be calculated as follows:

a. Determine the number of canisters needed to package the SNF assemblies or elements. Determine bow many canisters can be loaded in the appropkiate cask to arive at the number of shipments. Refer to Table 4 to determine number of axsemblies per shipment. 
Table 4. Capacity of various cask and canister combinations for transport of N-reactor, LEU, and HEU fued by rail.

\begin{tabular}{|c|c|c|c|c|c|c|c|}
\hline $\begin{array}{l}\text { Rail } \\
\text { cask }\end{array}$ & $\begin{array}{c}\text { Net } \\
\text { payload } \\
\text { (lb) }\end{array}$ & $\begin{array}{l}\text { Fuel } \\
\text { calegory }\end{array}$ & $\begin{array}{l}\text { Canister } \\
\text { sfize } \\
\left(\mathrm{fm} \cdot \mathrm{Hb}^{2}\right)\end{array}$ & $\begin{array}{l}\text { Covity } \\
\text { dimension } \\
\text { (in.) }\end{array}$ & $\begin{array}{c}\text { Cans } \\
\text { per cask }\end{array}$ & $\begin{array}{l}\text { Assent. } \\
\text { per } \\
\text { cabister }\end{array}$ & $\begin{array}{c}\text { Total } \\
\text { assem. } \\
\text { per cask }\end{array}$ \\
\hline JF-300 & 10,000 & $\begin{array}{l}\text { N-reacior } \\
\text { N-reactor } \\
\text { PWR } \\
\text { BWR }\end{array}$ & $\begin{array}{l}8 \times 120 / 900 \\
26 \times 126 / 3,300 \\
\text { Basket } \\
\text { Basket }\end{array}$ & $\begin{array}{l}37.5 \times 180 \\
37.5 \times 180 \\
37.5 \times 169 \\
37.5 \times 180\end{array}$ & $\begin{array}{c}4 \\
1 \\
\text { Baskea } \\
\text { Baskel }\end{array}$ & $\begin{array}{c}40 \\
200 \\
7 \\
18\end{array}$ & $\begin{array}{c}160 \\
200 \\
7 \\
18\end{array}$ \\
\hline$M-140$ & 32,000 & $\begin{array}{l}\text { N-reactor } \\
\text { HEU } \\
\text { LEU }\end{array}$ & $\begin{array}{l}26 \times 126 / 3,300 \\
8 \times 120 / 900 \\
8 \times 120 / 900\end{array}$ & $\begin{array}{l}70 \times 140 \\
70 \times 140 \\
70 \times 140\end{array}$ & $\begin{array}{l}4 \\
13 \\
25\end{array}$ & $\begin{array}{l}195 \\
1-2 \\
1-2\end{array}$ & $\begin{array}{c}780 \\
13 \\
25\end{array}$ \\
\hline MPC & 32,000 & $\begin{array}{l}\text { N-reactor } \\
\text { PWR } \\
\text { BWR }\end{array}$ & $\begin{array}{l}21 \times 187 / 3,800 \\
\text { Basket } \\
\text { Basket }\end{array}$ & $\begin{array}{l}57 \times 187 \text { est. } \\
57 \times 187 \mathrm{et} . \\
57 \times 187 \text {.st. }\end{array}$ & $\begin{array}{c}4 \\
\text { Basket } \\
\text { Basket }\end{array}$ & $\begin{array}{l}195 \\
21 \\
40\end{array}$ & $\begin{array}{l}780 \\
21 \\
40\end{array}$ \\
\hline BR-100 & 33,000 & $\begin{array}{l}\text { PWR } \\
\text { BWR } \\
\text { N-reactor }\end{array}$ & $\begin{array}{l}\text { Basket } \\
\text { Basket } \\
21 \times 187 / 3,800\end{array}$ & $48 \times 187$ st. & $\begin{array}{c}\text { Basket } \\
\text { Basket } \\
4\end{array}$ & $\begin{array}{l}21 \\
52 \\
150\end{array}$ & $\begin{array}{l}21 \\
52 \\
600\end{array}$ \\
\hline
\end{tabular}

a. Empty weight of canister sheld, assuming canisters are 1-in. thick.

b. Multiply the CPLM unit rates for the cask listed below by the one-way distance (in miles) and the number of shipments (from step a above) to obtain the CPLM cost. Choose the nearest rate for the intended destination that exceeds the actual distance required for the shipment.

\begin{tabular}{|c|c|c|}
\hline & IF-300 & M.140 \\
\hline Less than 200 miles: & \$182/mike & \$205/mile \\
\hline 200 to 1,000 miles: & $\$ 108 /$ mile & $\$ 127 /$ mile \\
\hline 1,000 to 2,500 miles: & s 87 mile & \$103/mile \\
\hline
\end{tabular}

c. Multiply the number of shipments (from step a above) by $\$ 18,000$ per shipment to obtain transportation fixed costs.

d. Add the CPLM (from step b above) to the frxed cost (from step $c$ above) to obtain the total transportation cost. 


\subsubsection{Cuidence for Determining Number of Reil Shipments}

Delermining the number of assemblies per cask will require detailed evaluations as discussed in Section 4.1.2. To facilitate developing PLCC estimates, guidance based on several simplifying assumptions is presented below.

\subsubsection{Hgh Enrkhed Urantum SwF.}

Fonr factors must be determined to develop the number of rail shipments:

Caniater size. If limited data are available on the fuel geometry and criticality specifications, an 8-in.-dismeter canister is recommended for HEU fuel (see Table 4).

Number of cantisters per cask If detailed information on the cask basket is not available, the assumed geometry for the basket should be based on maintaining a minimum 8-in. separation distance between the outer surface of any two adjoining canisters. As an example, the basket for the M-140 cask would have twenty-five 13-in.-square cavities with a 1-in. separation between each cavity. In this configuration, 13 of the cavities could be used for HEU and still maintain an 8 -in. separation between individual canisters.

Number of fuct elements per canister. Three limiting factors determine the number of fuel elements or assemblies that can be placed in a canister: the heat generation rate of the total fuel in the shipment must not exceed the specified heat removal capacity of the cask, the weight must not exceed the cask paytoad capacity (shown in Table 4), and the total $U_{235}$ content per canister should not exceed $40 \mathrm{~kg}$

Shickling. The cask must provide adequate radiation protection as measured at the outer surface of the cast. Maximum dose rate at the package surface should be below the $200 \mathrm{mrem} / \mathrm{hr}$ regulatory limit, and the maximum does rate $2 \mathrm{~m}(6 \mathrm{ft})$ from the package should not exceed the limit of 10 mrem/hr.

\subsubsection{Low Entchod Uranfurn.}

The number of rail shipments for LEU fued can be determined in the same way as for HEU, except that canisters are not restricted to the $40 \mathrm{~kg}$ of $U_{235}$ fimitation.

Canister tive. Because of lower entichment, the 21-in. MPC (currently being considered by DOE's Office of Civitian Radiogetive Management (OCRWM]) may be used. A 26-in.-diameter canister (recommended for the Mined Geological Repository at Yucca Mountain) may also be used.

Number of conitters per shipment If a 21-in. or a 26 -in.-diameter cask is used, the number of canisters per shipment is limited to four. However, if fuel is densely packed inside each canister, weight limitations will dictate a lesser number of canisters per shipment. Up to twenty-five \&- ty 120-in. canisters can be shipped in the M-140 cask. The M-140 can accommodate a 25 -channel basket with 13-in.-square cavities.

Nomber of fuel elements or asemblies per canister. The number of elements or assemblies per shipment should be calculated based on the three limitations mentioned ebove as well as specific criticality and heat generation calculations, if avajlable. 


\subsubsection{Other Speciat Cases.}

Special rescarch fuek. Fuels, such as TRIGA, plate, and Fort St. Vrain's high-temperature graphite reactor (HTGR), have normally been shipped by truck. There are no design, cost, or packaging guidelines for rall shipment of these types of fuel.

$\mathrm{N}$-reactor SNF. The average N-reactor fuel element is $2.5 \mathrm{in}$. in diameter, $21 \mathrm{in}$. long and weighs about $40 \mathrm{tb}$. A single 21 -in-diameter MPC canister loaded with about 780 fuel elements can be considered for estimating cost of $\mathrm{N}$-reactor rail shipments. This is based on meeting the weight linitation of the cask, but does not consider potential criticality or heat removal problems. 


\section{HAZARDOUS WASTE}

\subsection{Truck Shipment}

Transportation costs for hazardous waste are estimated based on the assumption that unshielded 48-ft-long truck trailers containing eighty-eight 500 -lb drums are used. This configurationt yields a total weight of $44,000 \mathrm{lb}$ per shipment. The total transportation costs can be calculated using the following steps:

a. Divide the total weight of waste (in pounds) by $44,000 \mathrm{lb} /$ shipment to obtain the number of shipments.

b. Multiply the CPLM unit rates listed below by the one-way distance (in miles) and the number of shipments (from step a above) to obtain the CPLM cost.

- Less than 200 miles: $\$ 3.00 /$ mile

- 200 to 1,000 mites: $\quad 52.50 /$ mile

- More than 1,000 miles: $\$ 1.95 / \mathrm{mile}$.

There are no significant fixed costs for transporting hazardous waste by truck to add to the variable cost given in step b (see Appendix A, Section A-4.4). However, for very short truck hauls, eg., less than $\mathbf{8 0}$ miles, trucking costs will be independent of mileage and will not fall below a minimum charge set by the trucking company (e.g., \$250).

\subsection{Rall Shipment}

Costs for transporting hazardous waste by rail are estimated based on the assumption that waste in drums or steel boxes would be moved in 40-ft-long intermodal (sealand) containers. The containers can be moved by truck or on rail flatcars. Each container would hold seventy-six 500-lb drums, yielding a total weight of $38,000 \mathrm{lb}$, or would hold eleven 3,945-lb boxes, yielding a total weight of about $44,000 \mathrm{lb}$. The total transportation costs can be calculated using the following steps:

a. Divide the total weight of waste (in lb) by $38,000 \mathrm{lb}$ (for drums) or $44,000 \mathrm{lb}$ (for boxes) to obtain the number of container loadis.

b. Multiply the CPLM unit rates listed below by the one-way distance (in miles) and by the number of container loaks (from step a above) to obtain the CPLM.

- 500 to 1,000 miles: $\$ 1,96 /$ mik.

- $\quad 1,000$ to 2,000 miles: $\quad \$ 1.74 /$ mile.

- More than 2,000 miles: \$1.46/mile 
c. Multiply the number of container loads (from step a above) by $\$ 750$ per container load to obtain the fuxed transportation costs.

d. Add the CPLM (from step $b$ above) to the fixed cost (from step $c$ above) to obtain the total transportation cost. 


\section{REFERENCES}

Feizollahi, F, and D. Shropshire, 1993, Waste Management Facilities Cost Information Repon for Spent Nuclear Fuel, EGG-WM-10670, March 1993.

Schmid, S. P., F. L. Danese, and M. W. Wankerl, 1993, "Site \& Facility Waste Transportation Planning Documents (SPD's) Status and Findings," in Proceedings of the Fourh Anntual Internationa! Conference on High Level Radioactive Waste Management, Las Vegas, NV.

TRW, Inc., 1993a, A Preliminary Evaluation of Using Multi.Pupose Canisters within the Chilion Radioactive Waste Management System, Doc. No. A0000000-AA-07-00002, March 1993.

TRW, Inc., 1993b, Reference Transpontation Data and Assumptions, May 1993.

Telephone contacts: A variety of cask vendors, transportation carriers, and DOE contractors supplied information for use in preparing this report. These include the following firms:

- Argonne National Laboratory, Argonne, Illinois: mileage tables.

- Babcock \& Wilcox, Lynchburg, Virginia: BR-100 SNF rail cask design inforuation.

- Chem Nuclear, Columbia, SC: cask data.

- CSX Railroad, Jacksonville, Florida: rail rates.

- EG\&G, Idaho Falls, Idaho: SNF rates and operational details.

- EnviroleasefGATX, Morristown, NJ; Intermodal equipment data.

- General Atomics, San Diego, California: FSV-1 truck cask rates for HTGR fuel and TRIGA Information.

- Nuclear Assurance Corporation, Norcross, Georgia: truck cask rates.

- Pacific Nuclear, various offices: SNF rail cask rates, TRUPACT-I design information, container information, and operational details.

- Santa Fe Railway, Schaumburg, Blinois: rail rates.

- SEG, Oak Ridge, Tennessee: LLW shipping cost and container data.

- Southera Pacific Transportation Company, San Francisco, California: rail rates.

- Tri-State Motor Transit Company, Joplin, Missouri: truck transportation rates.

- Union Pacific Railroad, Omaha, Nebraska: rail rates.

- Westinghouse, Carlsbad, New Mexico: TRUPACT.II shipping costs for TRU waste. 
- Vectra Technologies, Inc., Federal Way, Washington: NuPac Data.

- Cho Yang Shipping Lines, San Francisco, California: intermodal container, chassis costs.

- DSR-Senator, San Francisco, California: intermodal container cost.

- Mi-Jack, Portland, Oregon: intermodal container lift equipment cost. 
Appendix A

Methods, Bases, and Assumptlons 



\section{Appendix A \\ Methods, Bases, and Assumptions}

This appendix contains cost estimating methods, assumptions, and technical bases that were used to develop the planning life-cycle cost (PLCC) estimates. Specific additional assumptions and bases for waste stream transportation cost estimates are given in the main body of the report. First, technical assumptions as they apply to the four main waste types in this report are discussed in the following sections. Second, cost bases and assumptions as they apply to transport in intermodal containers and without are presented. Third, additional waste type-specific assumptions are presented. The backup data for the cost estinates are included in separate appendices.

\section{A-1 TECHNICAL ASSUMPTIONS}

The approach is based on developing welldocumented transportation cost estimates for various waste streams. Initially, waste is grouped into the following four categories: (1) LLW, MLLW, alpha LLW and MLLW, and GTCC LLW/DOE equivalent; (2) TRU waste; (3) SNF; and (4) hazardous waste.

\section{A-1.1 Shipment Assumptions for LLW, MLLW, Alpha LLW, Alpha MLLW, and GTCC LLW/DOE Equivalent}

Transportation of LLW, MLLW, alpha LLW and LLMW, and GTCC LLWDOE equivalent is accomplished either as contact-handled or remote-handled shipments. Contact-handled shipments are accomplished by placing the waste in DOE, DOT, and NRC approved packages (orums or boxes) and placing them in open-top truck trailers, rag-top trailess, enclosed trailers, or intermodal (sealand) containers. Remote-handled shipments are accomplished by placing the waste in packages and loading the packages into trailer or railcar-mounted casks (overpacks) that are licensed by DOE, DOT, and NRC. It is assumed that remote-handled waste will use Type B casks as definexl by the NRC regulations.

The physical forms of the waste include beterogeneous solid waste (consisting of soils, debris, trash, surface contaminated metals, stabilized liquids, etc.), activated metals, and organic liquids.

Before shipment, all waste is assumed to be characterized, treated, and packaged in accordance with al applicable regulations. Al] LLW is assumed to be transported in DOT/NRC certified Type A packages, such as 55-gal drums or standard waste boxes. 55-gal drums have a maximum capacity of $500 \mathrm{tb}(227 \mathrm{~kg}$ ) according to DOT regulations. Boxes are B25s, made of 12 . or 14-gauge steel, similar to those manufactured by Container Products Corp., of Wilmington, North Caroling. B25s have a volume capacity of $90 \mathrm{ft}^{3}$ and a maximum rated load capacity of 3,945 $\mathrm{lb}$ gross. To convert between volume and mass, assume a density of $70 \mathrm{lb} / \mathrm{ft}^{3}$. It is further assumed that if . radiological characterization shows that the total activity in a package exceeds $A_{2}$ values, then the package contents would be divided between one or more additional containers until the $A_{2}$ limits are met. Shipments of liquid organic waste would meet additional regulatory requirements specified for likuids (i.e., packages would contain adequate absorbent for twice the liquid volume, and a kak-tight overpack would be used).

Shipment requirements are determined by weight [tota] waste mass (kg) al each site divided by the appropriate vehicle capecity $(\mathrm{kg})$ ). For truck transportation, the DOT gross weight limit is $80,000 \mathrm{lb}$. Tractor-trailer combinations are assumed to weigh from 30,000 to $35,000 \mathrm{lb}$. The 
maximum payload weight has been taken to be $44,000 \mathrm{lb}(20,000 \mathrm{~kg})$. This would require a 48 - $\mathrm{ft}$ trailer to accommodate the shipment. For rail shipment of LLW, MLLW, and hazardous waste, it is assumed two 40-ft intermodal containers would be placed on a rail flatcar. Payload weight of these containers would be $38,000 \mathrm{lb}$ in the case of drums and $44,000 \mathrm{lb}$ for boxes.

\section{A-1.2 Transuranic Waste Shipment Assumptions}

Transportation of TRU waste is accomplished either as contact-bandied or remote-handled shipments. It is assumed that all contact-handled TRU waste shipments will be shipped in TRUPACT-I containers. Remote-handkd TRU waste will be shipped in Type B casks or SNF casks, depending on the specific characteristics of the waste shipment.

The physical forms of TRU waste are highly variable. They include heterogeneous solid debris, soiks, laboratory trash, surface contaminated metals, stabilized liquids, vitrified high level waste, and debris reactor cores and fuel rods assemblies, all of which may be contaninated with transuranic clements. It is assumed that the shipper will package waste in accordance with all applicable regulations.

For contact-handled TRU waste, the payload capacity of each TRUPACT-1I is limited to $7,265 \mathrm{lb} ; 7,200$ was used for calculations. Three TRUPACT-IIs are assumed to be transported per truck and six per rail car. Total shipment capacities are $21,600 \mathrm{lb}$ for truck and 43,200 lb for rail. Each TRUPACT-II can accommodate fourteen 55-gal drums. The safety analysis report for the TRUPACT-II did not address rail shipment of these containers. We sssume that TRUPACTs can be transported by rail. Rates were calculated using costs provided for SNF shipments, and include two buffer cars for the loaded portion of the shipment.

For remote-handled TRU waste, truck transport has been the normal method of shipment. Rates for overweight truck casks were supplied by Chem-Nuckear and NuPac. A legal-weight cask bas been design by NuPac, but the cask has not been built This cask, known as the NuPac 72-B, is suitable for shipment of vitrified high level waste and has a payload of $8,010 \mathrm{Jb}$. NuFac stated that the container could be shipped by truck or rail.

DOE has provided a cost estimate for shipping high kevel waste by truck to Yucca Mountain for disposal. The CPLM is given as $\$ 13.70$ for high level waste, which includes variable and fixed cost components. This estimate assumes a waste form similar to the vitrified material produced at Savannah River. No details are given for the type of container used in this shipment. Yucca Mountain's design basis for a repository cask suitable for vitrified high-level waste is 26-in. in diameter by 10-ft long. More information about this cost estimate is provided in Appendix $\mathrm{F}$.

Otherwise, the cost of shipping remote-handled TRU waste with a high specific activity by rail is roughty equal to the cost of shipping SNF ty rail (refer to Section 4,2). The assumption is based on the fact that remote-handled TRU waste containers reguire Type B casts with all the associated special handling and equipment related to SNF. This assumption has been validated by the DOE in their campsign to ship remote-handled TRU waste from the damaged reactor at Three Mile Island.

SNF cask vendors have provided their casks for remote-handled TRU waste shipgnents. For example, DOE has purchased three 125-B casks from NuPac to ship remote-handled TRU-related debris from Three Mile Island. Several shipments were made between 1986-1990. An articie describing these shipments is included in Append'x C. The distance traveled was 2,350 miles each 
way. Each shipment included three casks, four buffer cars, and a caboose. Two railroads, UPRR and Contail, provided the locomotives for these dedicated shipments. The Three Mile Island cost data represents a limited estimate of remote-bandled TRU rail shipping costs. A cost estimate based on DOE's Three Mile Island shipments is presented below:

Average railroad cost per TMI shipment, including security $\$ \$ 200,000$ Cask lease rate $\$ 7,150$ per day $X$ three casks $X 10$ days per shipment $\$ 214,500$ (based on method presented in A-3.2.3)

Total variable cost $=\$ 414,500$

Variable cost of $\$ 414,500 / 2,350$ miles $=$ cost per loaded mile of $\$ 176,30$

CPLM \$176.30/3 casks per shipment $=$ CPLM per cask of $\$ 58.77$

Fixed cost of 2 days demurrage per cask $=\$ 14,300$

\section{A-1.3 SNF Waste Shlpment Assumptions}

Transportation of SNF is accomplished by using licensed SNF casks. Hardware (casks) used for shipping SNF generally has features for cooling the SNF during shipment, provides shielding, and has impact absorbing features. Several different SNF casks are available (Schmid et al. 1993), and each one is licensed for a special type of SNF. Grouping of the various SNF casks, described in report EGG-WM-10670, is as follows: HEU fuel, which is assumed to have $>20 \%$ entiched uranium content, can be shipped in Type A canisters; LEU fuel, which is assumed to have <20\% enriched uranium content, can be shipped in Type B canisters; and Fort St. Vrain Facility fuel (high-temperature graphite fuel) can be shipped in Type $C$ canisters.

Using the above waste groupings, the CPLM unit rates and fixed costs were estimated by soliciting bids from carriers (trucking and raitroad) and commercial cask-rental firms. Their prices (which were specific to specified routes or lesse periods and timetables) per shipment were cakculated. Additional conversations with DOE contractors helped to clarify some of the data and assumptions. The information obtained trom the vendors has been summarized and presented in variable CPLM and fixed cost per shipment format.

Additional assumptions are as follows:

- Casks are avajlable $\$ 68$ days per year, based on a 240 -day year and a $70 \%$ utilization rate.

- Average truck cask weight is $40,000 \mathrm{lb}$ for legal weight truck shipments of SNF.

- Cask loading and unloading is performed by facility operations staff.

- Two days are required to load and unload an SNF cask.

\section{A-1.4 Hazardous Waste Shipment Assumptions}

Transportation of hazardous waste is accomplished by truck in bulk in appropriate truck trailers, or in packages (dnums or boxes) placed in open-top truck trailers, rag-top trailers, encksed trailers, or intermodal (sealand) containers. Transportation of hazardous waste is accomplished by rail in drums or boxes placed in intermodal containers. The physical forms of the waste include 
heterogeneous solid waste (consisting of soils, debtis, trash, sutface-contaminated metals, stabilized liquids, etc.), activated metak, and organic liquids. Before shipment, all waste is assumed to be characterized, treated, and packaged in accordance with all applicable regulations. The packages are assumed to be DOT-certified, such as 55-gal drums or standard waste boxes. 55-gal drujts have a maximum capacity of $500 \mathrm{lb}(227 \mathrm{~kg}$ ) according to DOT regulations. Boxes are B25s, made of 12 or 14-gauge steel, similar to those manufactured by Container Products Corp., of Wilmington, North Carolinh. B25s have a volume capacity of $90 \mathrm{ft}^{3}$ and a maximum rated load capacity of $3,945 \mathrm{lb}$ gross. To convert between volume and mass, assume a density of $70 \mathrm{lb} / \mathrm{ft}^{3}$.

Shipment requirements are determined by weight [total waste mass (kg) at each site divided by the appropriate vehicle capacity (kg)]. For truck transportation, the DOT gross weight limit is $80,000 \mathrm{lb}$. Tractor-trailer combinations are assumed to weigh from 30,000 to $35,000 \mathrm{lb}$. The maximum payload weight has been taken to be $44,000 \mathrm{lb}(20,000 \mathrm{~kg})$. This would require a 48 -foot trailer to accommodate the shipment. For rail shipment of hazardous waste, it is assumed two 40-ft intermodal containers would be placed on a rail flatcar. Payload weight of these containers woukd be $38,000 \mathrm{lb}$ in the case of drums and $44,000 \mathrm{tb}$ for boxes.

\section{A-3 COST BASIS AND ASSUMPTIONS}

\section{A-3.1 Shipment Primarily by Rail In Intermodal Containers}

Cost estimates for transporting contact-handled LLW, contact-handled MLLW, and hazardous waste by rail were based on movement in intermodal (sealand) containers. It is assumed DOE owns or leases (from a third party) a number of intermodal containers and chassis, which would be dedicated to the task of transporting these types of DOE waste. Four hypothetical destinations for the waste were chosen: (1) Hanford Site, (2) Idaho National Engineering Laboratory (INEL), (3) Nevada Test Site, and (4) Oak Ridge National Laboratory (ORNL). These are hypotheticai disposal sites and are also the assumed locations where containers and lift equipment are stored.

A facility needing to ship waste would call for empty intermodal containers from the nearest storage location. The shipping facility (waste-generating facility) would call a trucking company to meet the empty intermodal container at the noarest public rail loading ramp. The trucking company would bring the empty container to the shipping facility, where it would be loaded by the shipping facility. The shipper is assumed to have a standard forklift (not included in the transportation cosi) for loading the waste onto the truck. The truck will bring the loaded container to the public ramp, where the container is placed on a rail tlatcar. The disposal installation will purchase a special lift device to transfer loaded intermodal containers between the rail flatcar and truck chassis; this lift device will be part of fired transportation costs. The containers, after reaching one of the destination installations and being unloaded, are returned to the pool of containers at the destination installation.

It is assumed that rail lines directly service the destination facility. The containers will still need to be trucked between the rail spur and treatment, storage, and disposal facilities within the destination installation. A lift device will be needed for this transfer, and a small number of chassis will be needed for the in-plant moves within the instaltation. 


\section{A-3.1.1 Costs of Trucking Segments}

Trucking costs make up part of the rail transportation costs presented in Sections 2.1.2 and 5.2 (trucking costs are already included in the rail costs presented). The basis for these trucking costs are as follows.

It is assumed that rail lines do not directly service the shipping facility nor go directly to the TSD facilities at the destination facility. Therefore, truck shipment will augment rail transportation at both ends of the rail mowement. A total truck shipinent distance of 150 miles was added to the rail shipment.

Assumptions regarding the trucking segrnents of rail transportation costs are substantially the same as trucking assumptions used elsewhere in this report (see Section A-3.2.1). The main exception is an absence of a demurrage charge associated with the pickup, loading, or dropoff of the intermodal container. It is assumed that drums or boxes can be loaded into and unloaded from the container in less than 2 hours and that lifton and liftoff of the container at the rail ramps can also be accomplished within that time.

\section{A-3.1.2 Coets of Rail Segment}

Rail movenent comprises the main, central seginent of the trip described in Sections 2.1.2 and 5.2. Rail rates are based on quotations from railroads for specific routes. Actual rates are typically defined by a contract between the shipper and railroad. Shipments of contact-handled LLW, contact-handled MLLW, and bazardous waste are assumed to involve the movement of two 40-foot intermodal containers on an 89 -foot flatcar. The railroad provides the flatcar. A short-haul rate quote was provided by Union Pacific Railroad (UPRR) for the route from Seattle, Washington, to Nampa, Idaho (655 miles). Two medium-length rate quotes were provided by CSX for the route from Bettis Atomic Power Plant, Pennsylvania, to Savannah River Site, South Carolina (947 miles), and for the route from Rocky Flats Plant, Colorado, to the Y-12 Plant, Tennessee (1,586 miles). A long-haul rate quote was provided by UPRR for East St. Louis, Illinois, to Hanford, Washington (2,040 miles) (see Table A-1).

Table A-1. Rail rate quotes for containerized contact-handled LLW, contact-handled MLLW and hazardous waste.

\begin{tabular}{|c|c|c|c|c|}
\hline Origuti & Destination & Rail mikage & $\begin{array}{l}\text { Roundtrip rail } \\
\text { rate per } \\
\text { container }\end{array}$ & Railroad \\
\hline Seattle, WA & Nampa, ID & 655 & $\$ 1,125$ & UPRR \\
\hline $\begin{array}{l}\text { Bettis Alomic } \\
\text { Power Plant, } \\
\text { PA }\end{array}$ & $\begin{array}{l}\text { Savannah River } \\
\text { Site, SC }\end{array}$ & 947 & $\$ 1,250$ & $\operatorname{csx}$ \\
\hline $\begin{array}{l}\text { Rocky Flats } \\
\text { Plant, CO }\end{array}$ & Y-12 Plant, TN & 1,586 & $\$ 2,575$ & $\operatorname{csx}$ \\
\hline E. St. Loujs, IL & Hanford, WA & 2,040 & $\$ 2,750$ & UPRR \\
\hline
\end{tabular}




\section{A-3.1.3 Treneportation Herdware Coets}

Transportation hardware costs consist of intermodal containess and chassis, and one lift device at the disposal facility. These costs work out to a charge of \$750 per container shipped that DOE will assess the shipping facility for the use of the equipment.

The costs of a container, chassis, and lift device are amortized over 5 years using a straight-line depreciation. The total cost of equipment is divided by 5 years to yield an annualized cost. The annual maintenance cost is assumed to be $25 \%$ of the annualized capital cost, and the cost of money, overhead, and fee are assumed to be $50 \%$ of annualized cost. The sum of these annualized costs are divided by 168 days to obtain the daiky container cost. (It is assumed the equipment will be used $70 \%$ of the time 240 days per year, or 168 days per year.) An average purchase cost of $\$ 3,500$ for a 40 - $f t$ sealand container and $\$ 3,000$ for a chassis were obtained from Cho Yang Lines and DSR-Senator Agency. The daity cost for containers and chassis is multiplied by 7 days, assurning the equipment will be used this long during the average round trip movement. Two cost quotes for a lift device were obtgined: $\mathbf{\$ 3 5 0 , 0 0 0}$ was quoted by $\mathbf{M i}-J a c k$ Corporation, Portland, Oregon, and $\$ 280,000$ was quoted by Tenco, Union City, Caltiforoia. These two amounts were averaged to arrive at a cost of $\$ 315,000$ per lift device.

\section{A-3.2 Shlpment in Other Than Intermodal Containers}

\section{A-3.2.1 Truck Carrier Coots}

Shipment of waste by truck is based on the following assumptions:

- Carrier costs include the following:

- Dispatching crews from their base of operations to pick up an empty cask,

- One day of denurrage at the shipper's facility whike the cask is loaded.

- Transporting the loaded cask from the shipper to the receiving facility.

- Ore day of demurrage at the shipper's facility while the cask is unloaded.

- Return of the empty cask from the receiving to the shipping facility.

- Carrier surcharges for special equipment used to ship radioactive material.

- Carrier insurance costs.

- Security escort as a direct quote where available, or at $20 \%$ of the carrier's variable costs.

- Carrier cost is converted into dollars per mile by assuming a crew (two drivers) covers 900 round-trip miles per day (or 450 loaded miles per day).

- Carrier freight rates are based on specific rate quotes from Tri-State Motor Transit for three specitic routes. 
- Carrier detention (demurrage) costs are calculated based on a daily rate of $\$ \mathbf{\$ 4 0}$, which includes stand-by costs for the special spent fuet crew during cask bading/umbading operations.

\section{A-3.2.2 Rail Cartier Costa}

Cost estimates for rail shipment in other than intermodal containers are based on tariff quotations from different railroads. The estinates assume that normal service can accommodate the 35 miles-per-hour-in-transit requirement. Actual rail rates are typically defined by a contract between the shipper and the railroad. It is also assumed that rail lines directly serve the shipping facility and the destination facility and that both facilities have the necessary lift devices (cranes, forklifts) to move waste onto and off the rail cars.

SNF shipments are assumed to require the movement of a loaded cask, its dedicated flatcar, two buffer cars, and a caboose for escort personnel. This astumption is similar to the requirements of Carolina Power and Light, which has maintained a dedicated lleet of its own equipment for muttiple shipments over several years. They contract out only the traction (power) equipment from CSX. They own two IF-300 casks, two buffer cars, and a caboose. Four IF-300s have been in service for nearly 20 years. Pacific Nuclear Fuel Services (formerty GE Morris, Illinois) owns the other two IF-300 casks. Most of the fixed cost portion of SNF rates are based on lease rates for the IF-300 cask supplied by Pacific Nuclear. This cask has a basket design suitable for most types of DOE fuel; however, a new basket must be designed for the canisters listed in Table 4. A cost estimate cost for a new basket design is beyond the scope of this report.

Tariff rates were provided on a cost-per-hundredweight basis. The total weight of TRU waste and SNF shipments were estimated for both the loaded (heavy) and unloaded (light) segments of the trip. These costs were combined and divided by the total mileage for the estimated range to arrive at the CPLM.

Two short-haul rate quotes were received for trips in the 200-mile range. These were provided by Southern Pacific (Mare Island, California, to Sacramento, California, about 80 miles), and CSX railroad (Newport News, Virginia, to Portsmith, Virginia, about 238 miles). The rate quote in the 1,000-mile range was provided by UPRR for a trip between Sacramento, California, and Scoville, Idaho. UPRR provided other rates for shipments from Idaho Falls, ldaho, to both Harford, Washington, and Las Vegas, Nevada. It is interesting that the rates from Idaho Falls were kwer than the rates from Sacramento. UPRR explained that distance is not the main factor in rail rates. The amount of rail traffic along a given corridor is the main factor in determining the shipping cost. For the 1,000- to 2,500-mile range, a combined move of neafly 2,200 miles was priced out for a shipment between Idaho Falls and Barnwell, South Carolina. This rate is divided between UPRR and CSX. A 1,300-mile quote for a shipment between Morris, Illinois, and Albuquerque, New Mexico, has also been received from Santa Fe Railway. A comparison of only the loaded tariff rates for various distances has been prepared (see Tabie A-2). 
Table A-2. Rail rate quotes for SNF and TRU waste.

\begin{tabular}{llcll}
\hline Origin & Destination & Mileage & Loaded SNF rate & Tariff \# \\
\hline Marc Island, CA & Sacramento, CA & 80 & $\$ 2 . \% / \mathrm{cwt}$ & SPTC \\
Newport News, VA & Portsmith, VA & 238 & $\$ 2.92 / \mathrm{cwt}$. & CSXT 4600g \\
Sacramento, CA & Scoville, ID & 1,020 & $\$ 12.15 / \mathrm{cwt}$ & UPRR 4605d \\
Idaho Falls, ID & Hanford, WA & 641 & $\$ 9.07 / \mathrm{cwt}$ & UPRR 4605d \\
Idaho Falls, ID & Las Vegas, NV & 671 & $\$ 8.84 / \mathrm{cwt}$ & UPRR 4605d \\
Idaho Falls, ID & E. St. Louis, MO & 1,510 & $\$ 13.73 / \mathrm{cwt}$ & UPRR portion \\
E. St. Louis, MO & Barnwell, SC & 665 & $\$ 6.44 / \mathrm{cwt}$ & CSX portion \\
Idaho Falls, ID & Barnwell, SC & 2,175 & $\$ 20.17 / \mathrm{cwt}$ & Combined Rate \\
Argonne & Albuquerque, NM & 1,315 & $\$ 7.15 / \mathrm{cwt}$ & Santa Fe 4043-A \\
& & & & \\
\hline
\end{tabular}

Security related costs were assumed to be $30 \%$ of the cask rental charges during the loaded portion of the move. Train crew and security personnel may have to be relieved while a shipment is in progress to maintain the designated rate of travel. This often involves special arrangement to deliver a crew to a remote location when an existing crew has run out of hours as prescribed by the DOT.

\section{A-3.2.3 Trensportation Hardware Costs}

Transportation hardware costs include equipment capital and maintenance costs. Capital costs associated with hardware needed for shipment of contact-handled LLW, MLEW, and alpha LLW and LLMW are assumed to be negligible.

Capital costs for casks, trailers, and rail cars used doring shipment of remote-handied waste and SNF are estimated using either a commercial lease rate or a purchase cost, as described below.

The annual commercial lease rate submitted by the commercial cask teasing firms are averaged to obtain a basic daily leasing cost. The basic annual leasing cost is divided by 168 days to obtain the daily tease rate. The daily lease rate for a given trip is calculated by dividing the one-way distance by $\mathbf{4 5 0}$ miles to obtain the number of days the hardware will be in use. If the number of days is a fraction, it is rounded up to the next whole number and multiplied by 2 to determine the cask rental period for the round trip. Next, the number of days is multiplied by the daily lease rate to arrive at the variable cost component of the cask rental. For example, a 1,000-mile trip requires 3 days each way at 450 miles/day, multiplied by 2 , resulting in 6 days total cask rental.

The cost of purchased casks is depreciated straight-line over 5 years. The annualized capital cost is obtained by dividing the capital cost into 5 years. The annual maintenance cost is assumed to be $25 \%$ of the annualized capital cost. The cost of money, and the cask vendor overhead and fee are assimed to be $50 \%$ of the total annualized capital costs. The sum of the annualized capital, 
maintenance, and vendor overhead profit and fee is divided by 168 days to obtain the cask daily capital payment cost.

The calculation of rates for daily cask rental are presented in Tabte A-3.

Tabla A-3. Rates for daily cask rental.

\begin{tabular}{|c|c|c|c|}
\hline Vendor & Cask & 1-year lease rate & $\begin{array}{c}\text { Daily rate based on } 168 \text { days per } \\
\text { year }\end{array}$ \\
\hline General Atomics & FSV.1 & $\$ 432,000$ & $\$ 2,571$ \\
\hline Dept. of Defense & M-140 & $\$ 1,400,000$ & $\$ 8,333$ \\
\hline DOE & BMI-1 & NA & $\$ 1,200$ \\
\hline Pacific Nuckar & IF -300 & $\$ 1,620,000$ & $\$ 9,643$ \\
\hline NAC & NLI-1/2 LWT & $\$ 648,000$ & $\$ 3,214$ \\
\hline
\end{tabular}

The cask lease rates for the IF-300 were provided by Pacific Nuclear, of San Jose, Catifornia. The lease terms are $\$ 4,500$ per day based on a 1 -year commitment ( 360 days). The total for the year is $\$ 1,620,000$. In previous reports, capital costs were divided by 168 days (70\% of 240 operating days)

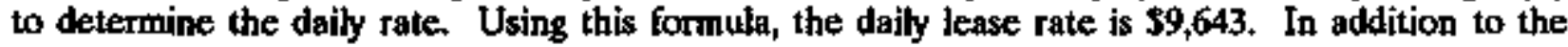
capital cost of the lease, a charge for annual operation and maintenance (O\&M) related costs will be added to the capital rate. Pacific Nuclear estimated $\$ 50,000$ for annual O\&M-related expenses. This number is divided by 168 and equals approximately $\$ 300$ day. The total variable cost rate of the cask rental is $\$ 9,943$ per day.

The Department of Defense has provided cost information on the M-140 cask used by Naval Reactors. The basic hardware cost is $\$ 4,00 \%, 000$, which equates to $\$ 800,000$ per year, assuming use for 5 years. The annual maintenance cost is $\$ 200,000$, and the overhead cost is $\$ 400,000$ per year.

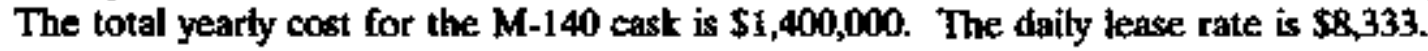

The fixed cost portion of the rate is assumed to be two times the daily rate. The average of the 2-day lease rate was used as the basis for the foxed cost portion, which equals $\$ 18,000$ (rounded). There is no train demurrage since the cask and its flatcar can be spotted at the shipper's or receiver's facility.

TRUPACT-II casks are assumed to weigh $12,000 \mathrm{lb}$ empty and 19,200 lb full. Rail rates are based on cost-per-hundred-weight quotes. The loaded segment of the move includes two buffer cars at 24,000 lb each. The return assumed six empty TRUPACTs and no buffer cars. No security escorts are prowided for TRU shipments. The total cost per loaded mile is the sum of loaded and empty return cost divided by the distance between the shipper and the destination facility. No rail car exists to ship TRUPACTs by rail. A safety analysis report, design, and fabrication of hardware by athers are in progress. 


\title{
A-4 BASIS FOR WASTE STREAM SPECIFIC COST ESTIMATES
}

\author{
A-4.1 LLW, MLLW, Alpha LLW, and Alpha MLLW
}

The backup data used to prepare the cost information present in Section 2 is located in Appendix B. The main source of information was provided by Scientific Ecology Group (SEG). This data was presented in an earlier WMFCI report, and has been repeated here to give the user a single source of cost information. Information on intermodal equipment and transport rates has been added 10 Appendix $B$.

\section{A-4.2 TRU Waste}

The backup data used to prepare Section 3 is located in Appentix C. Pacific Nuclear provided the TRUPACT-II specifications. Phil Gregory, Westingbouse-WIPP, provided cost information based on life-cycle cost studies prepared by his office. Bill Dean, EG\&G INEL, provided cost information on the TMI shipments. A journal article on the TMI shipping campaign is also included.

\section{A-4.3 Spent Nuclear Fuel}

The backup data for SNF transportation cost estimates is broken down into two parts. Appendix D contains the information on SNF truck shipments, and Appendix E contains the information on SNF rail shipments. Union Pacific Railroad has extensive experience with SNF shipments to INEL. CSX is the contract carrier for Carolina Power and Light, who has an ongoing program to ship SNF by raih. Tri-State Motor Transit has an excellent reputation as a highway carrier. It should be noted that the greatest expense, in the short distance shipments, is dispatching the crew from their base of operation. For example, the 30-mile quote represents an internal move at Hanford. However, the crew must travel 1,800 miles each way to pick up the shipment and deliver it. Another hidden cost is incurred if shipping containers are not stored at the shipper's or receiver's facility.

\section{A-4.4 Hazardous Waste}

Transportation costs for hazartous waste are similar to those presented for contact-handled low-level radioactive waste. Relevant backup data are presented in Appendix B. Costs for shipment of hazardous waste are sightly lower than radioactive waste, because these shipments differ in the following ways:

- There are many more carriers for hazardous waste than radioactive waste

- No significant fixed cosis are related to container rental and demutrage

- Hazardous waste does not tequire complex packaging and secondary containment

- Bulk containers, such as dump trucks, roll-off boxes, and vacuum trucks are readily avatlable 
- No requirement exists for health physics technicians to inspect loaded trucks before release

- Insurance and training related costs are kwer.

The cost difference between radioactive low-level shipments and hazardous waste is rellected in lower CPLM rales for hazardous waste. The limited number of radioactive waste shippers increases the cost of mobilization of transportation equipment to the shipper's facifity. In addition, shipment of radioactive waste requires monitoring by health physics technicians (per NRC regulations CFR 10) and compliance with DOT regulations (Subpart I of CFR 49.173), which lead to additional fixed costs for radioactive waste shipments. 


\title{
Appendix B
}

Backup Data for Low-Level Waste Shipments

\author{
Appendix B-1: SEG Quotation/Cask Data \\ Appendix B-2: Chem Nuclear Cask Data \\ Appendix B-3: NuPac Cask Data
}


Appendlx B-1

SEG Quotation/Cask Data

B-2 
February 18, 1993

\author{
Lisa Penaska \\ M.K. Environmental \\ I 80 Howard Street \\ 12t Floor \\ San Francisco, CA 94105
}

Dear Lișa,

Scientific Ecology Group is pleased to provide the attached data sheets for your reference. SEG -has a full line of process containers and radwaste shipping casks to meet a variety of needs.

Feel free to contact me at (615) 376-8tL5 if you have any further questions. We are loaking forward to hearing from you.

Sincerely,

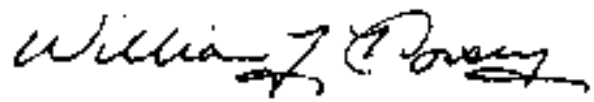

William J. Horsey

Manager Field Services

Lir-93-05 
SCIENTIFIC ECOLOCY GROUP, IHC.

$\lambda$ Westingiouse subsidiary

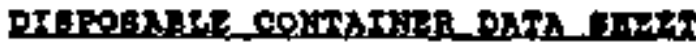

Data Sheet No. RT-14

Rey. No.

Date

Reference

Approved
6 s-2a-9! DCN $91=054$

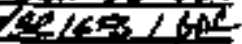

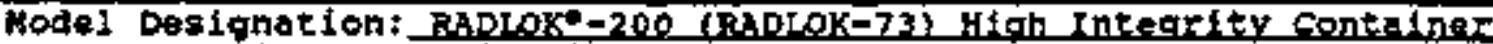
South Coroilna Certification No.: DHsc-HTC-PL=007

Cark Application: 3-B2B Gakk \& nt-142 Cark
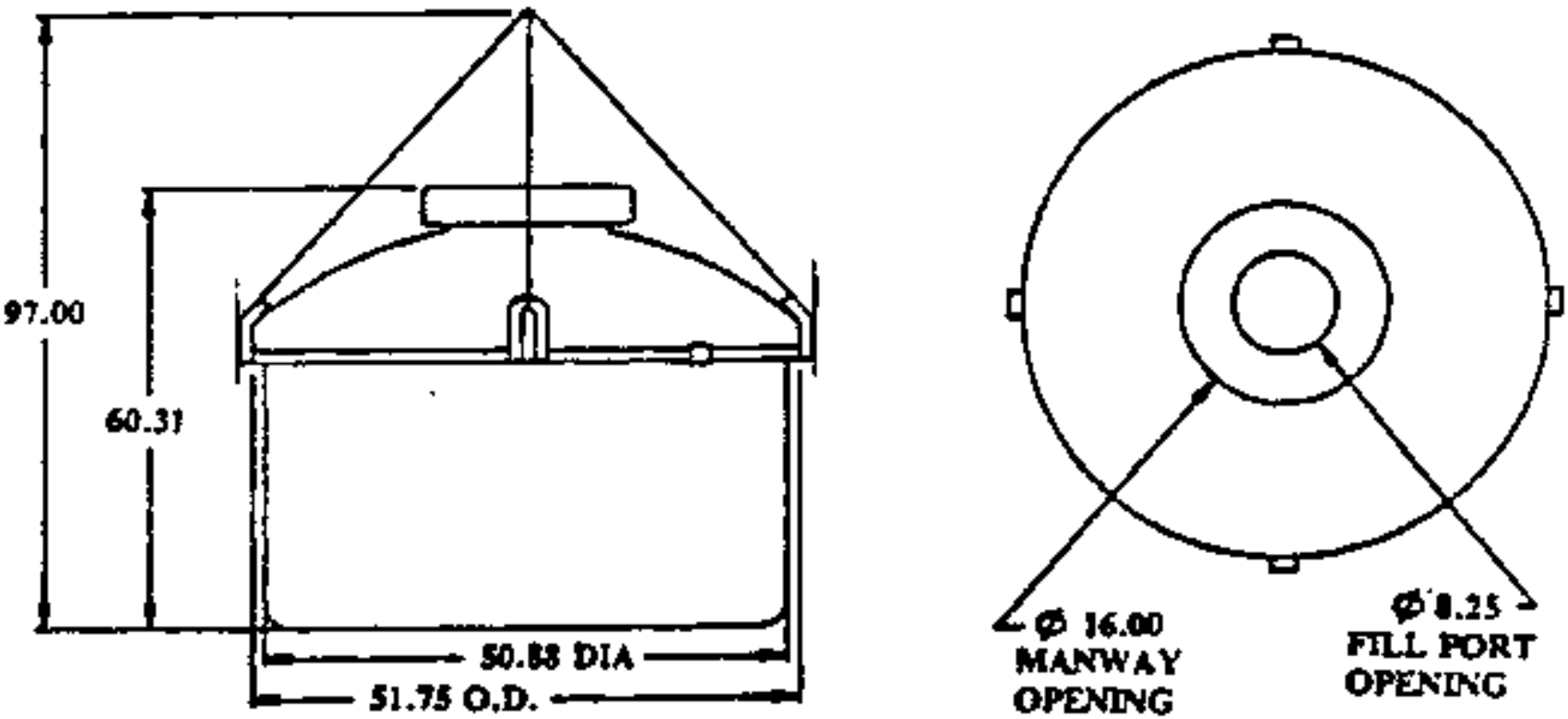

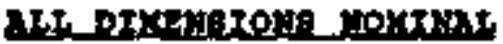

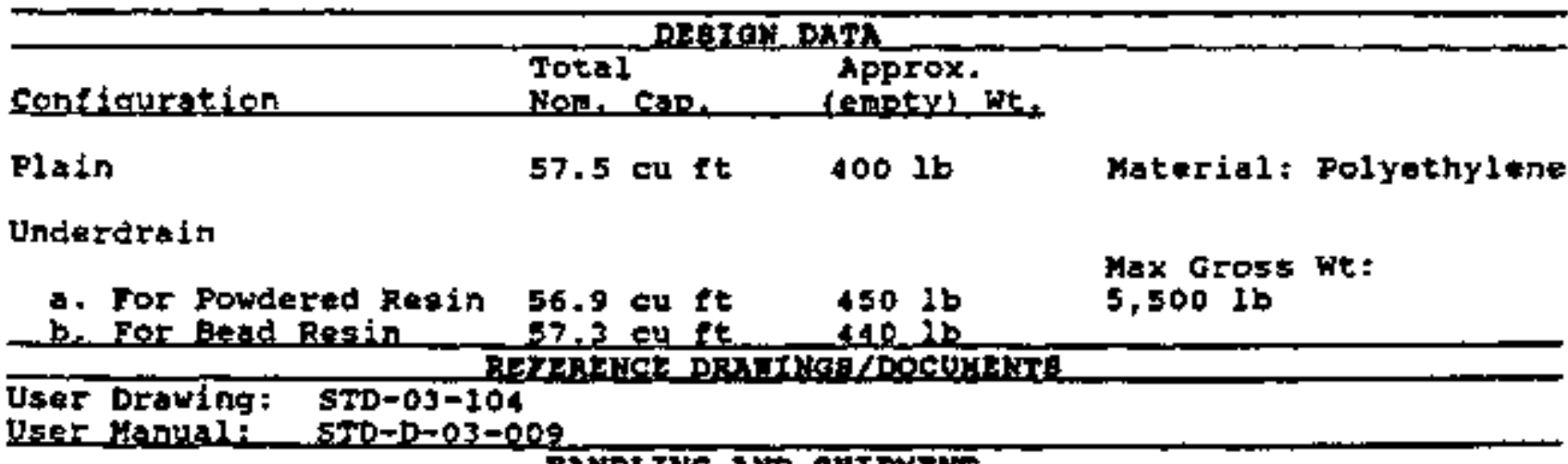

ifsting:

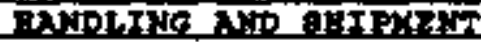

.losure: Tro (2) concentrie threaded elosures 


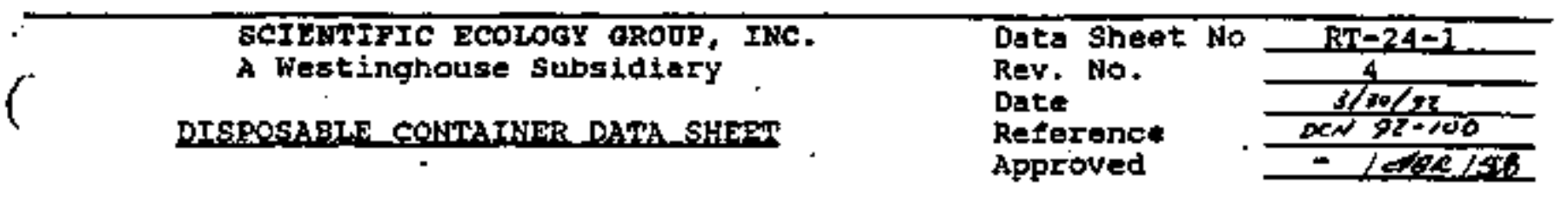

SEG Hodel Designacion: RADLOK - 179 High Integrity Contsiner

South Carolina Certification No, : DFEC-HTC-PI=005

cask Application: All HN-100 casks exeant the Hil-100 Series 3 w/shield insert
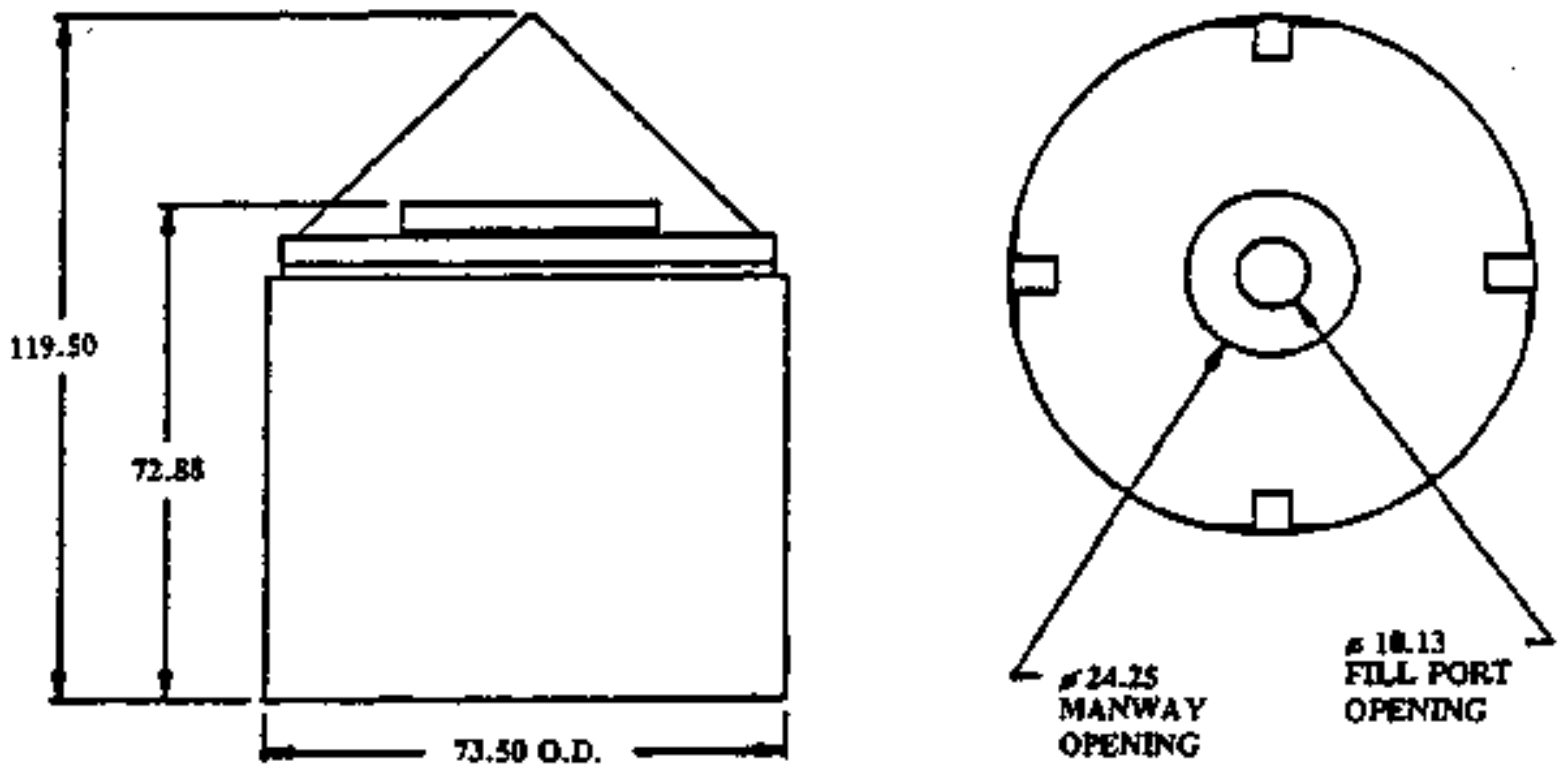

ALI DIMENSIONS NOMTNAI

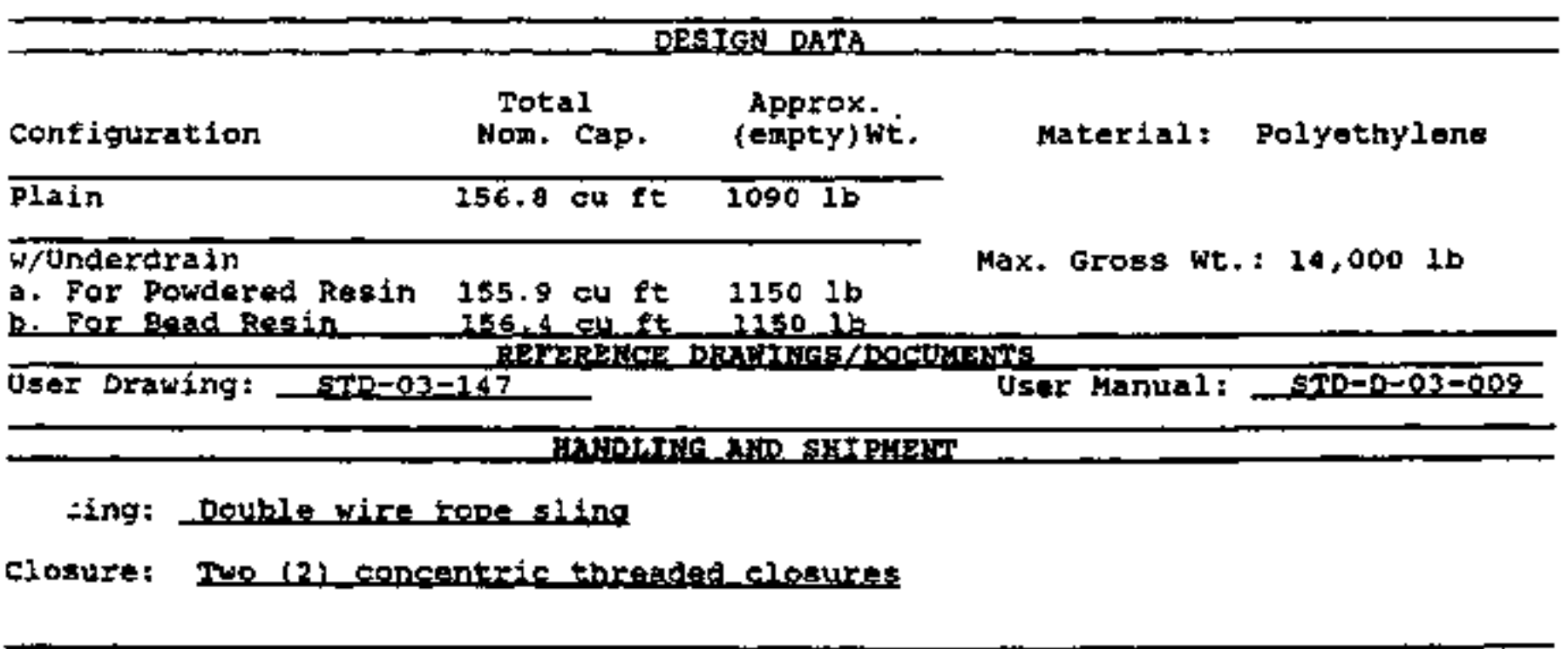



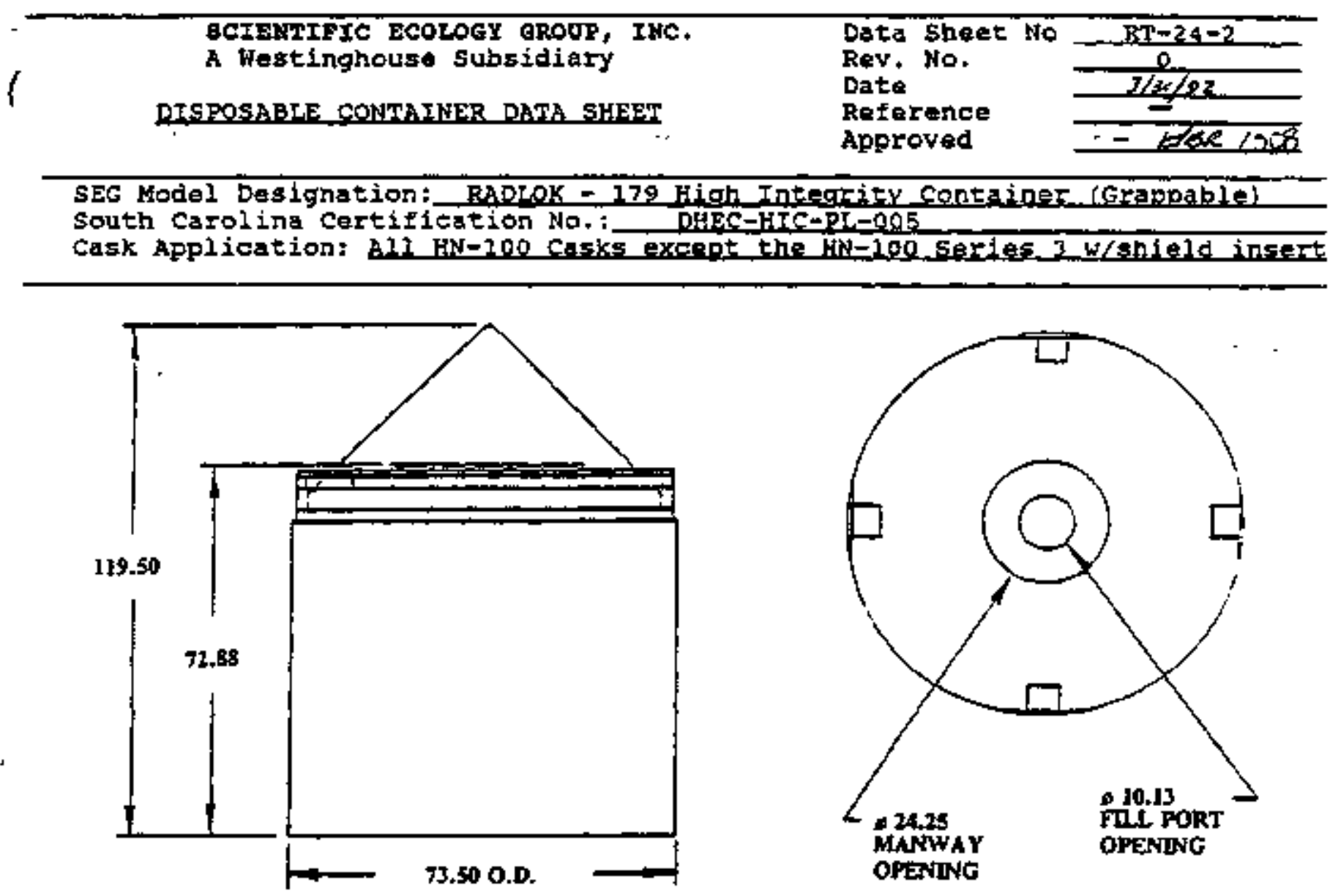

ALL DIMENSIONS NOMINAL

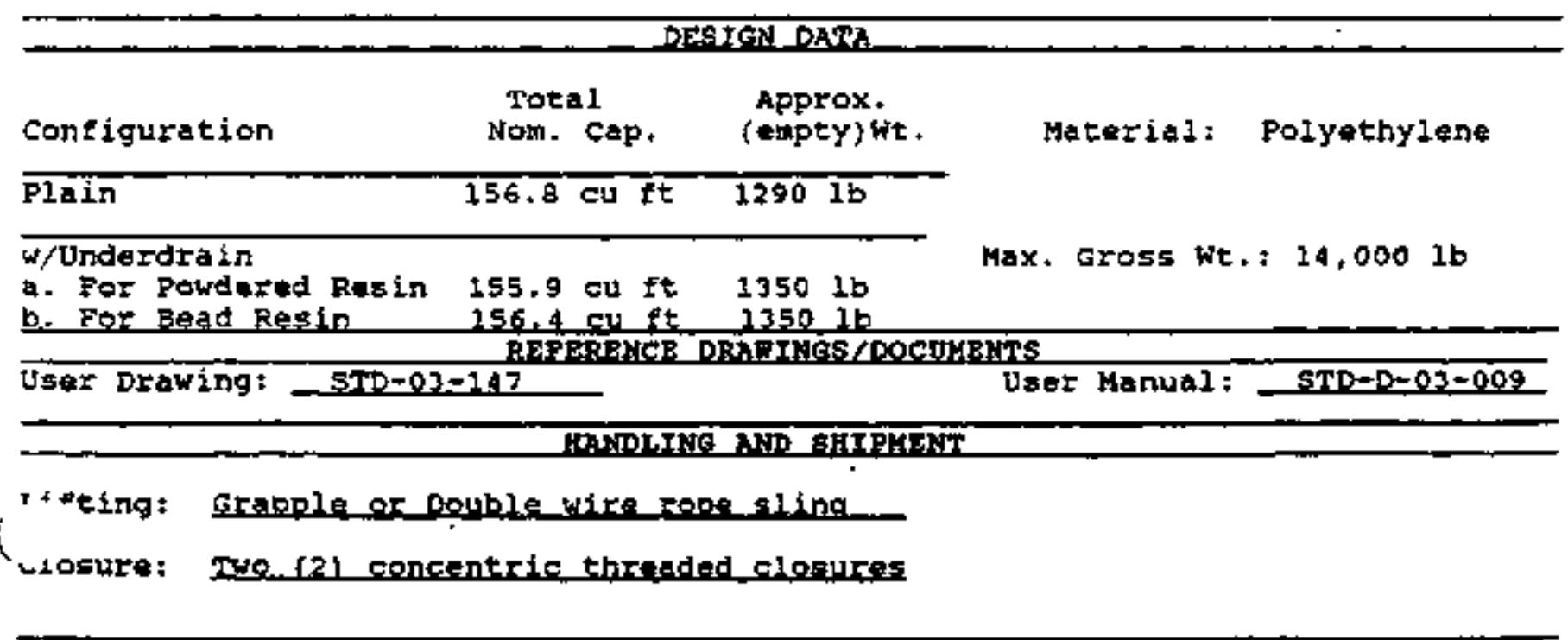


GCIENTIFIC ECOLOAY GROUP, INC.

A Westinghouse subsidisfy

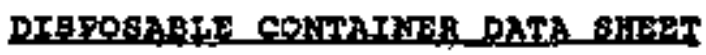

Dats Sheet No. RT-25-1

ReV. No.

Date

Refarence

Approved

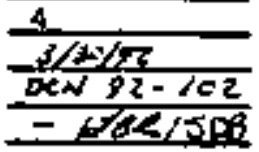

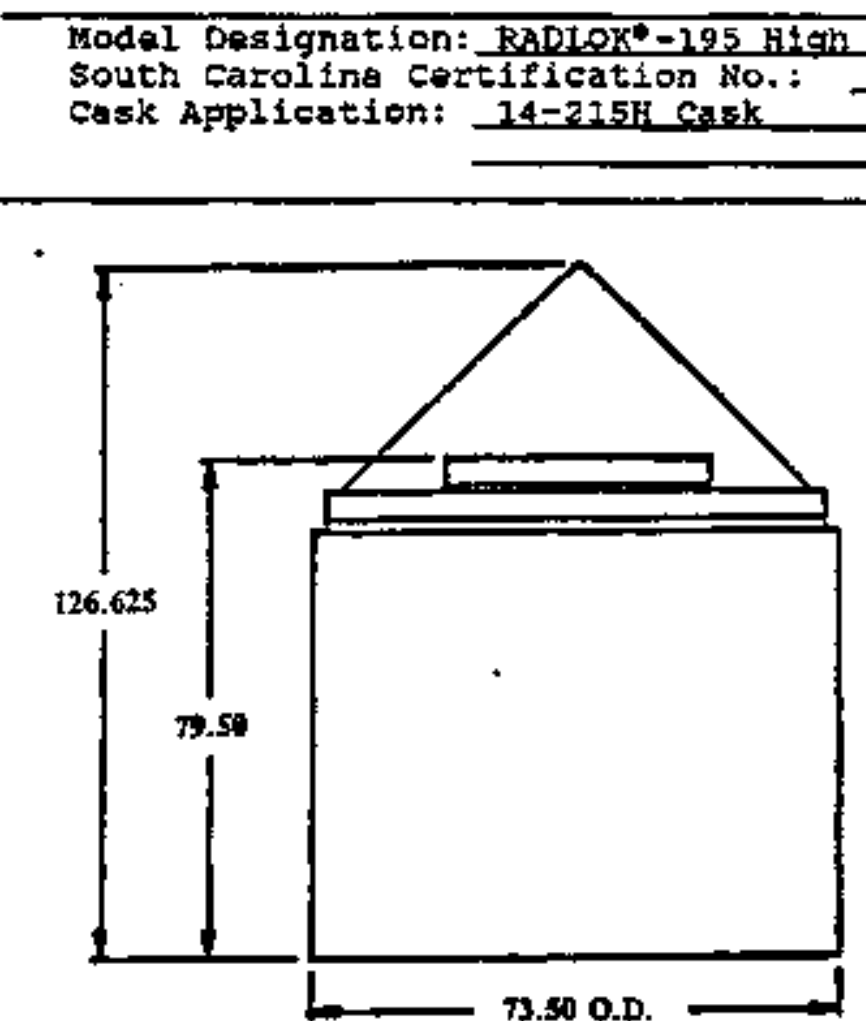

Interity containat

DHEC-HEC $=2 L=005$

South Caroline Certification No.

-

73.50 O.D.

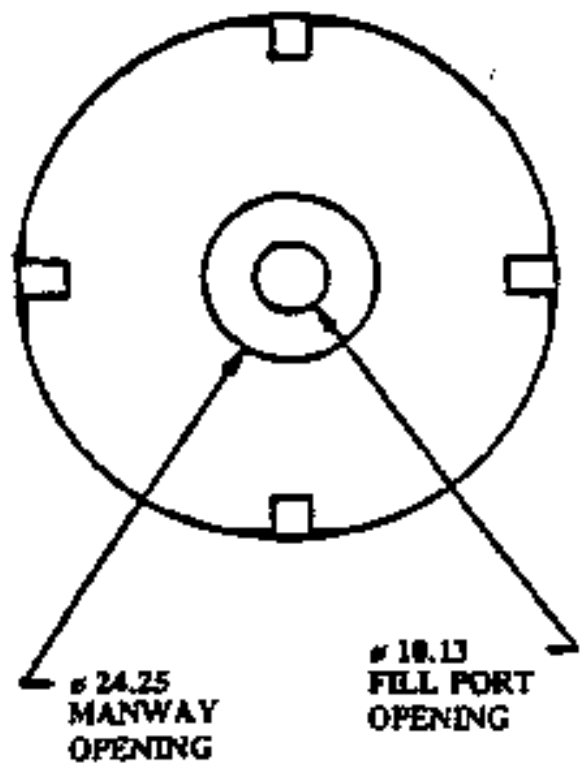

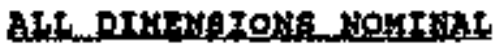

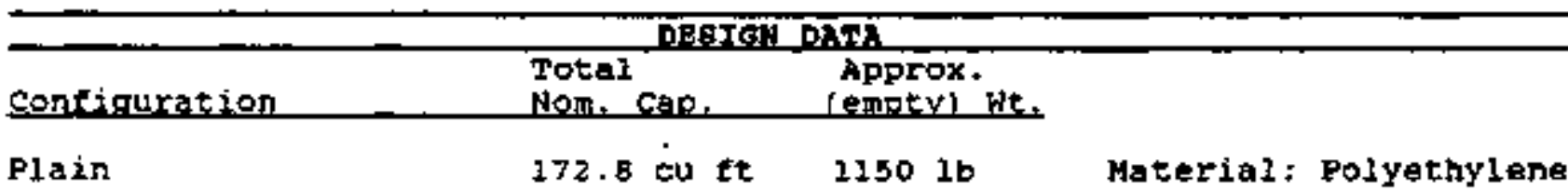

Underdrain

a. For Powdered Regin $171.9 \mathrm{cu}$ ft $1210 \mathrm{lb}$

Max Gross Wt:

15,500 ib

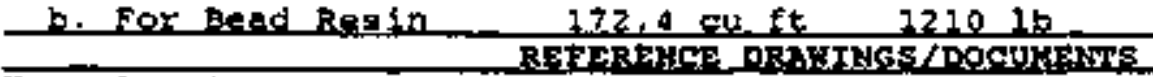

User Drawing: STD-03-147

user Manuli: sTn-D-03-009

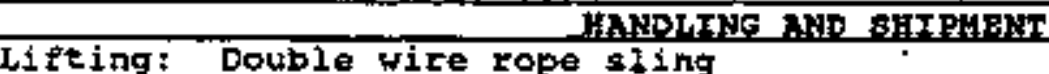

ilosure: Two (2) concentric threaded closures 


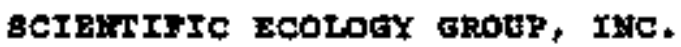
A Westinghouse subsidiary

\section{DXBPOAABTE CONTHTNER DATK EHFET}

Data Sheet No. RT-25=2

Rev. No.

Date

Reference

Approved

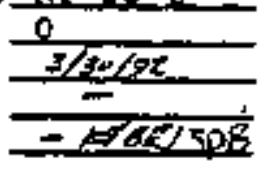

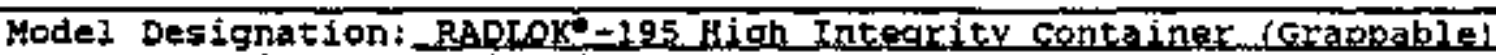
South carolina certification No: : DHFC-HIC-Pr-OOS

Cask Application: $14-215 H$ Cakk
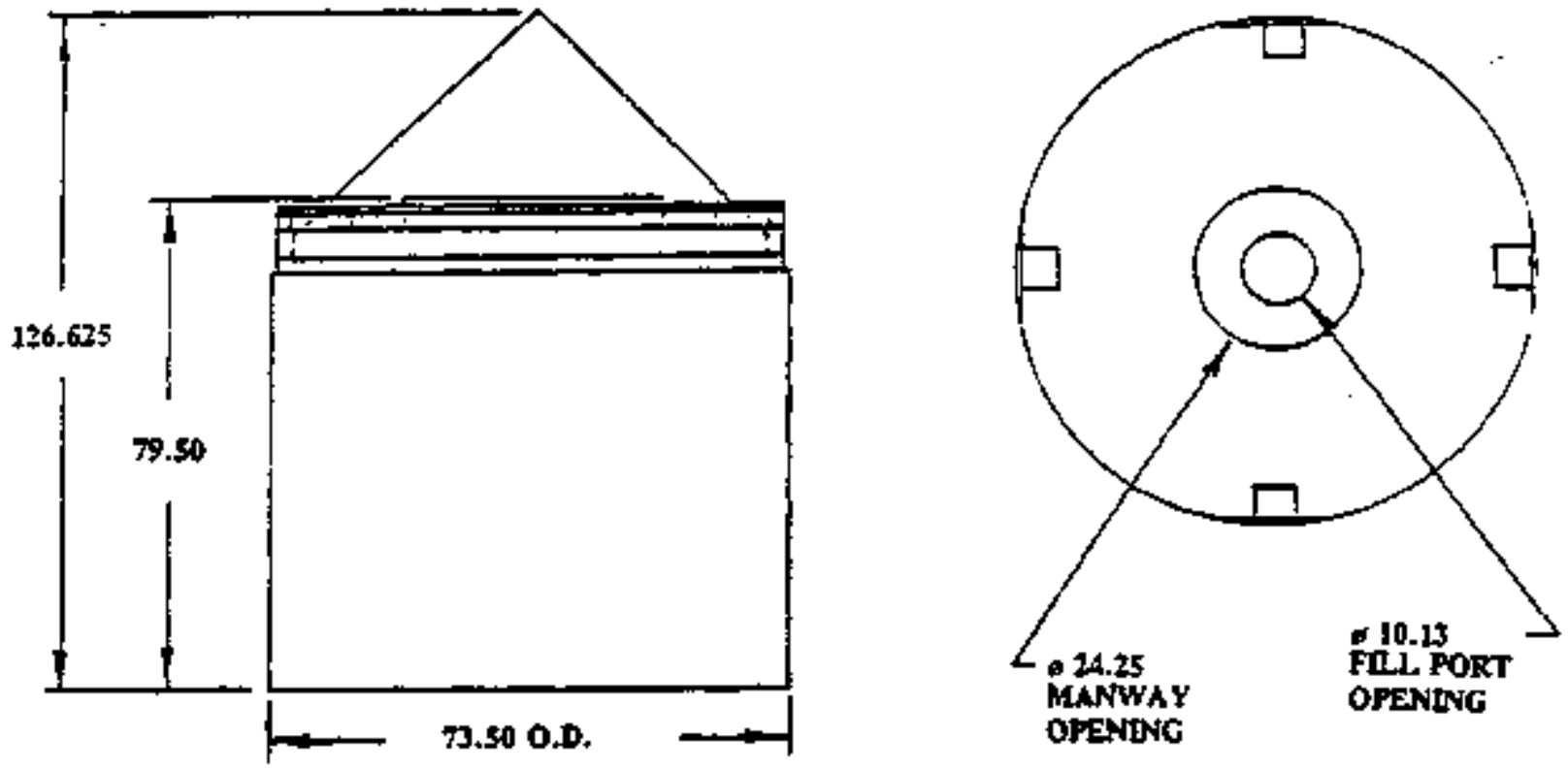

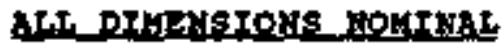

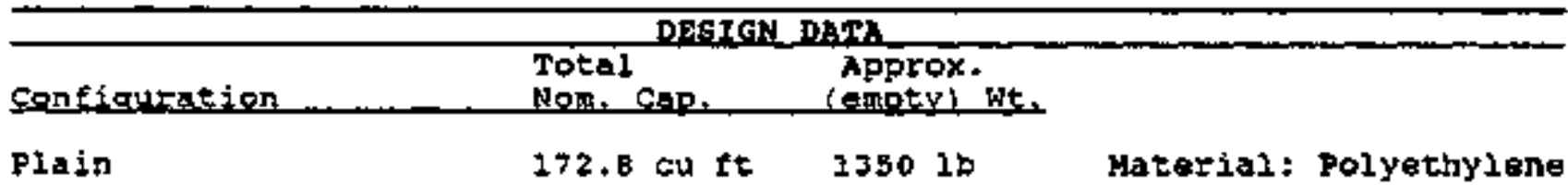

Underdrain

a. For Poudered Restn 171.9 cu $\mathrm{ft}$ 1410 1b

Max Gross Wt:

b. For Besd Resin 272,4 ch it 2420 ib $15,5002 \mathrm{~b}$

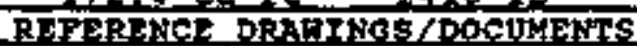

User Drawing: STD-03-147

Iser Manuli $\$$ STD $=0-03-009$

FANDTTHE AND SHTPUEA

Lifting: Grapple or Double vire rope sling

Losure: Two (2) concentric threaded closures 
SCIENTIFIC ECOLOTY GROUP, INC. A Wostinghouse subsidiaty

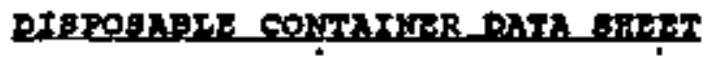

Data sheot Ho. RT-12

Rev, No.

Date

Reference

xpproved

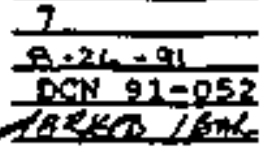

$28<x+\sin$

Mode1 Designation: RADLOK +100 (BADigK-263) High Integrity container

South Caroline certification Ho.: DHFG-HIC+PL=005

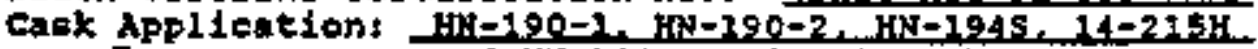

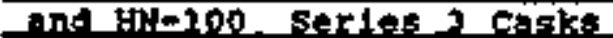
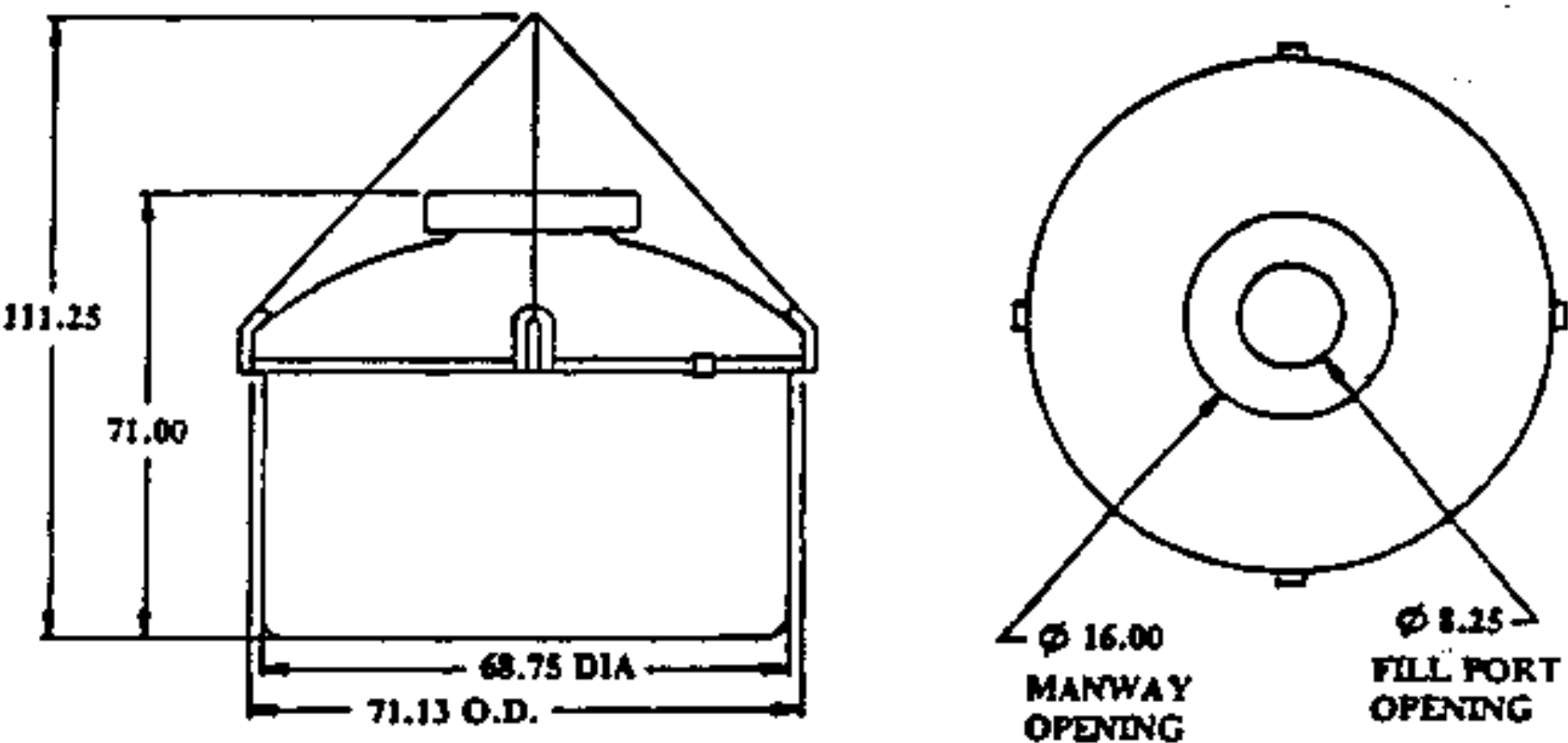

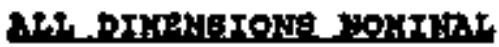

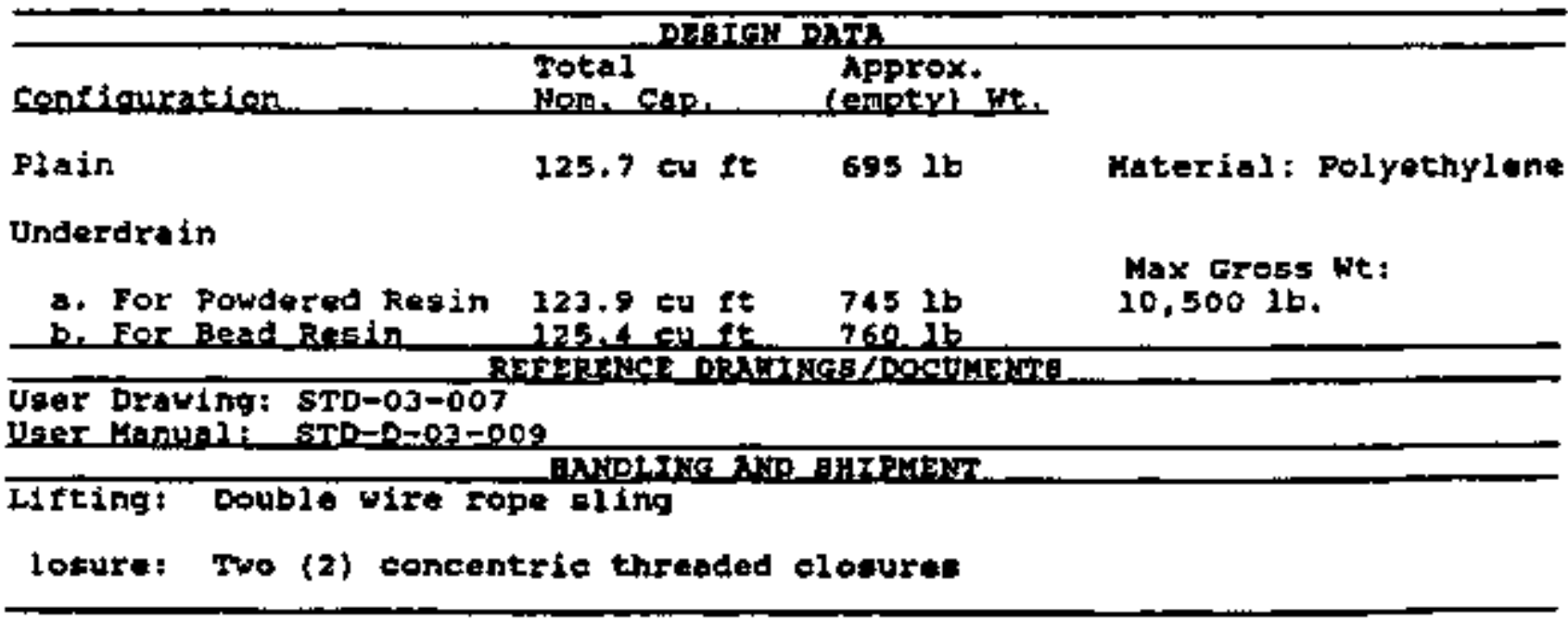


SCIDATIFIC ECOLOGY GRODP, INC. A Hestinghouse subsidtary

DISPOSAPLE CONTATYRR_DATA GHEET
Data sheet No. RT=17-1.

Rev, No.

Date

Re ferenct

Approved

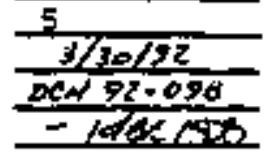

Model Designation: BADLOK -500 (RADLOK-236) hith Intagrity Containet South Carolina Certification No.: DHEC-HIC-PL-014 Gask Application: $\mathrm{HN}=142 \mathrm{CaBK} \& \mathrm{HN}=100$ Cask
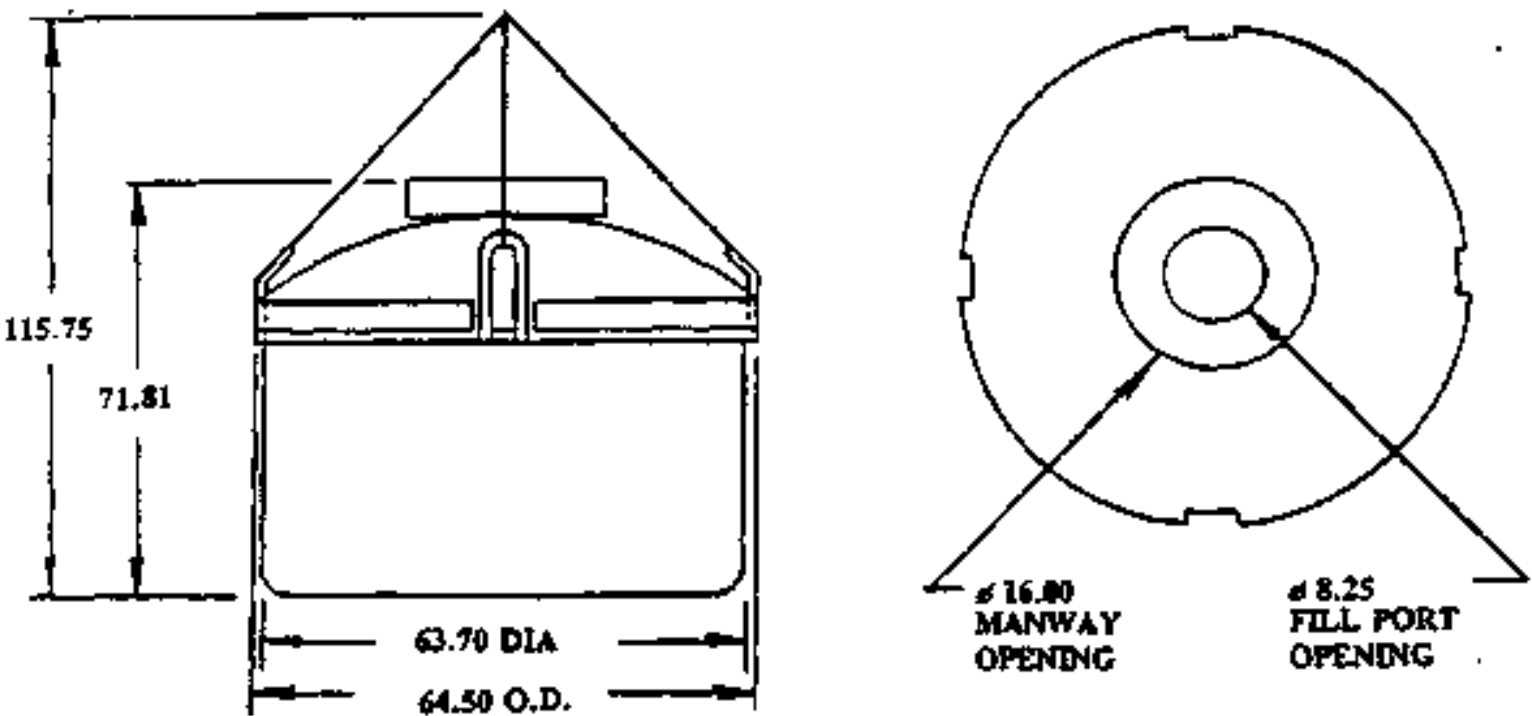

ALT DIMEASTONS WOMTKAL.

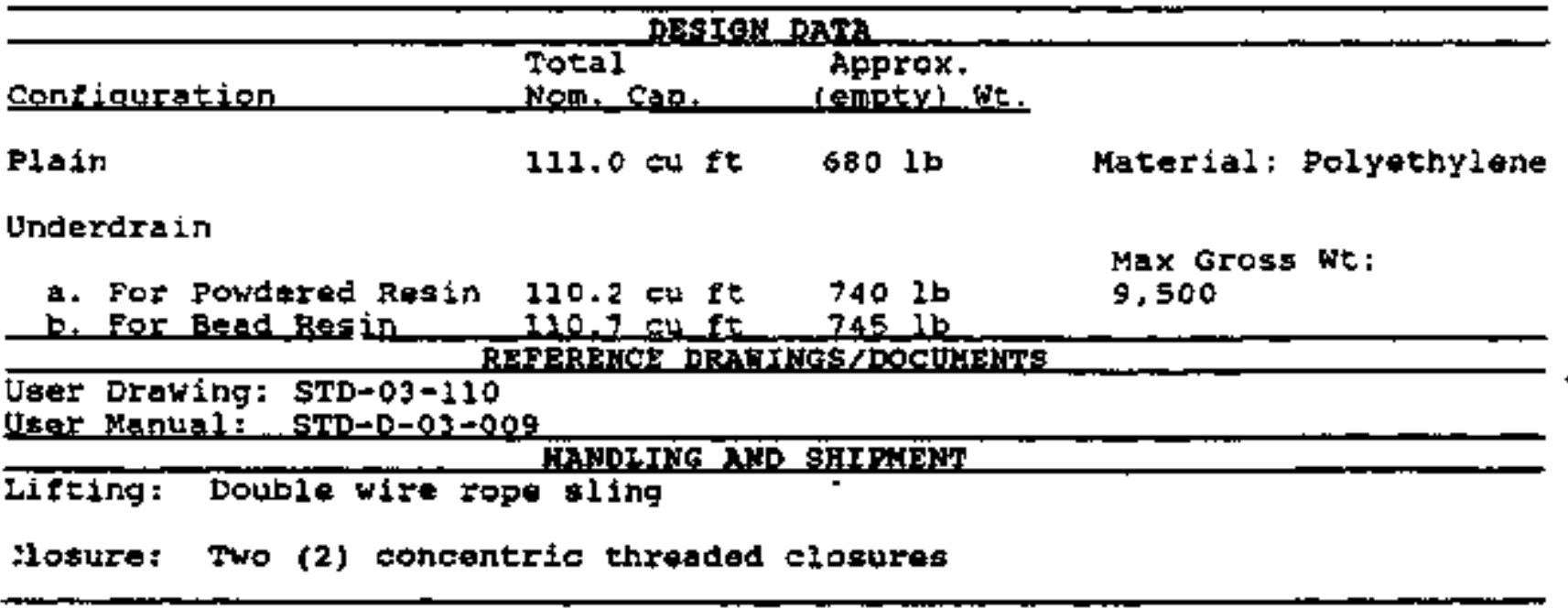


BCIENTITIC ECOZOGY GRODP, TNC. A Westinghouse Subsidiary DIBPOSARTE CONTATHER DATA SHFET
Dets shetet No. RT $-17-2$

Rev. No.

Date

Reference

Approved

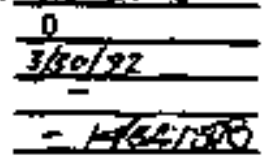

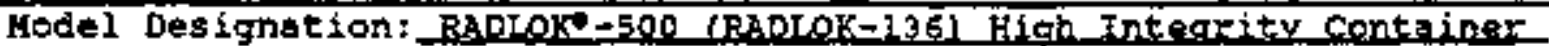
(A)

South Carolina certification No.: DHtC-HUC-PL-014

cask application: HN-142 cask \& mo-100 cask
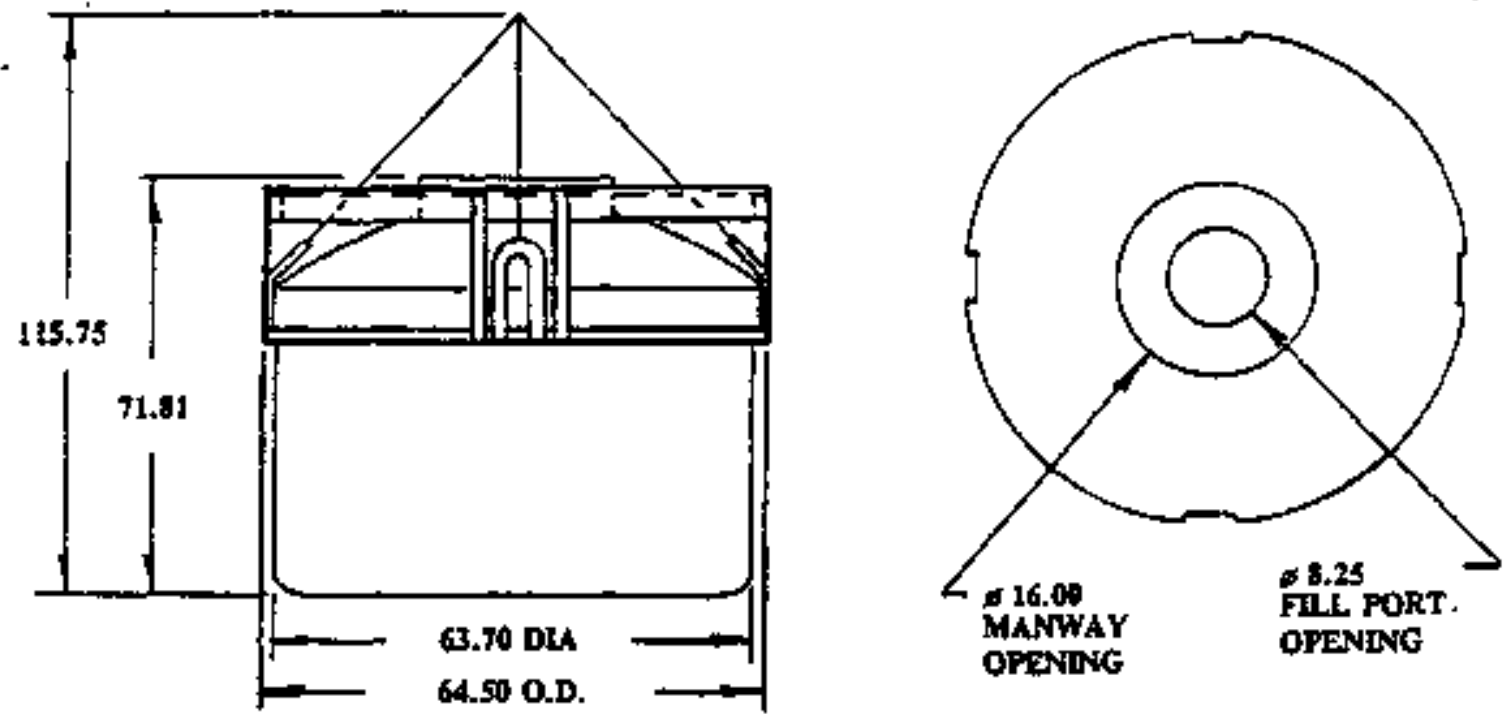

At, DTHeverows MorTin.

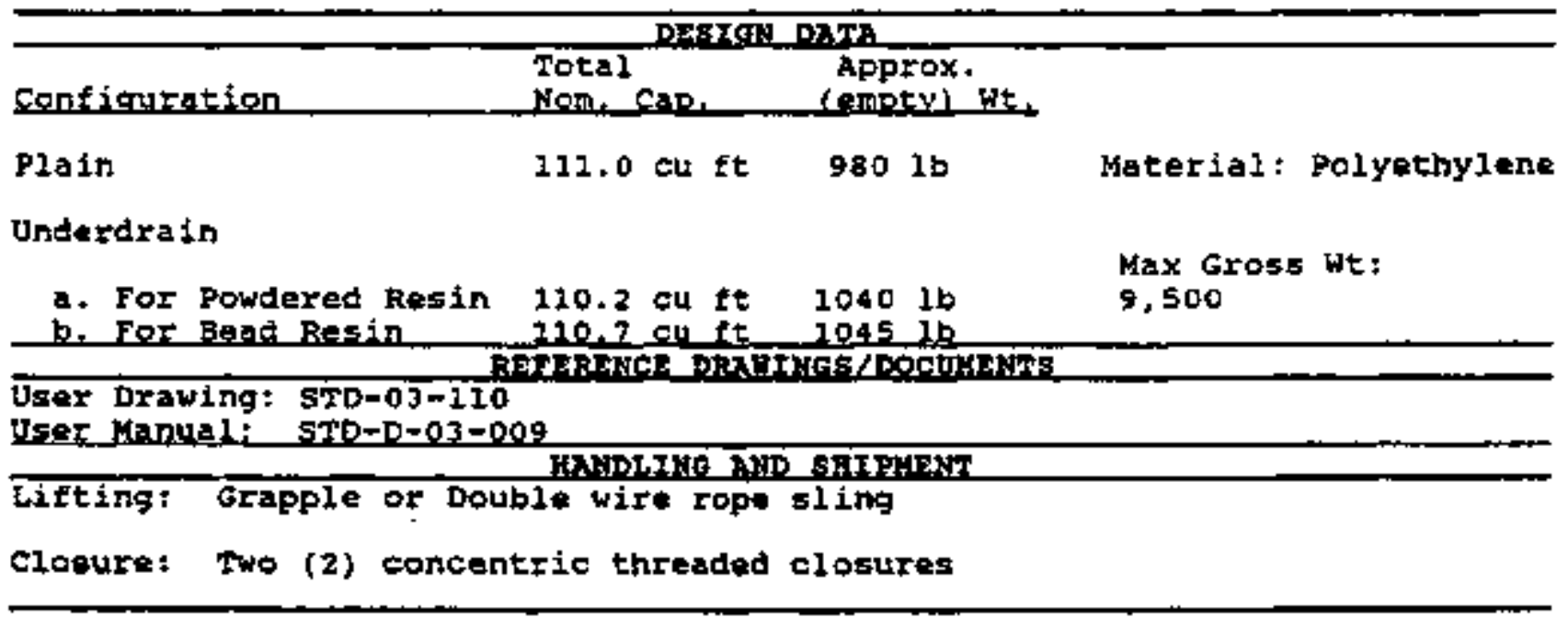


(

RAOMASTE_SHTPPTHE_CASK DATA_SHEDT
Data sheet No.

Hev. No.

Date

Refer (EWR/ECN)

approved

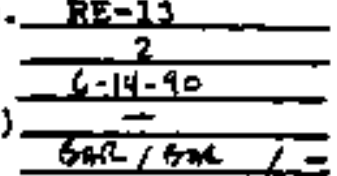

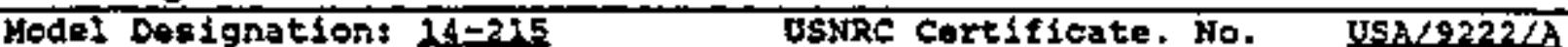

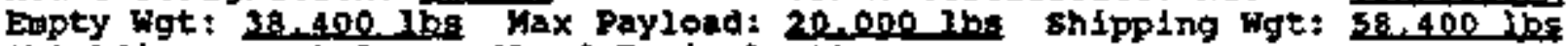
shielding: 2..72._. (Lead Eguivelent)

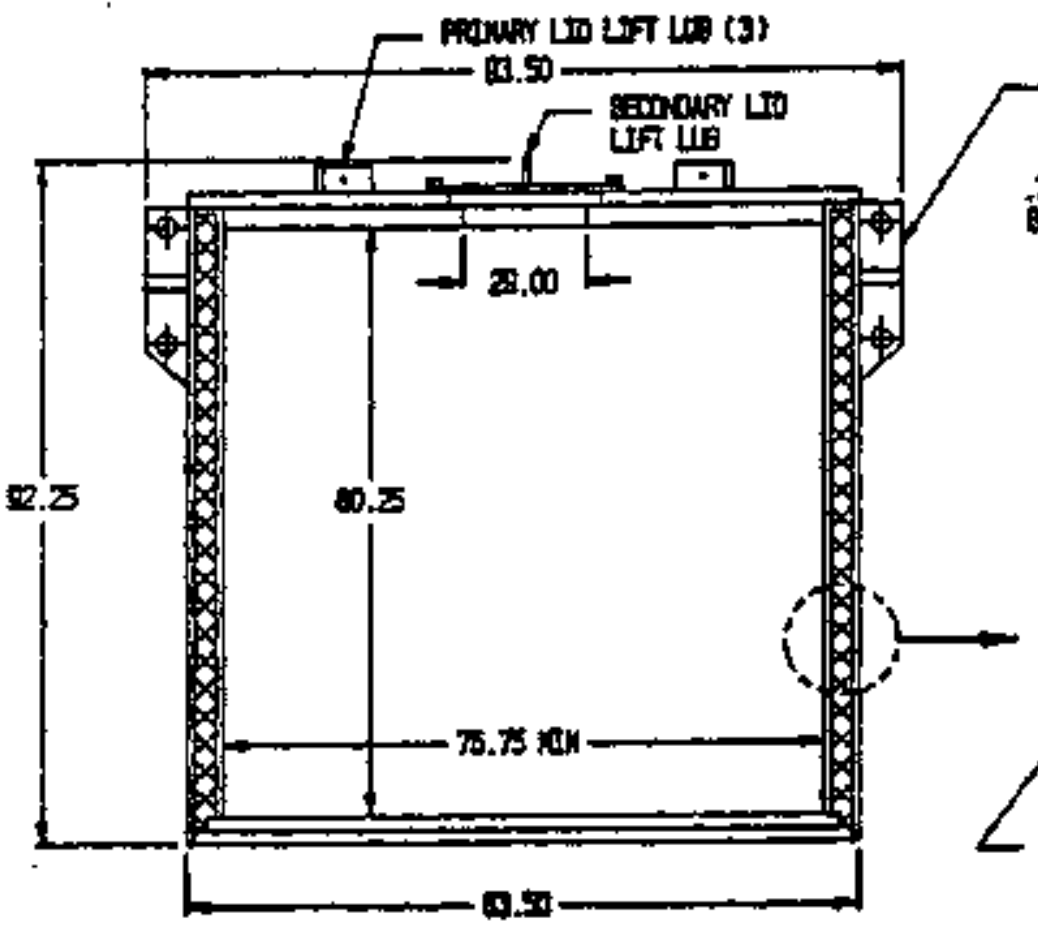

crex 1 1ri 15 [4]

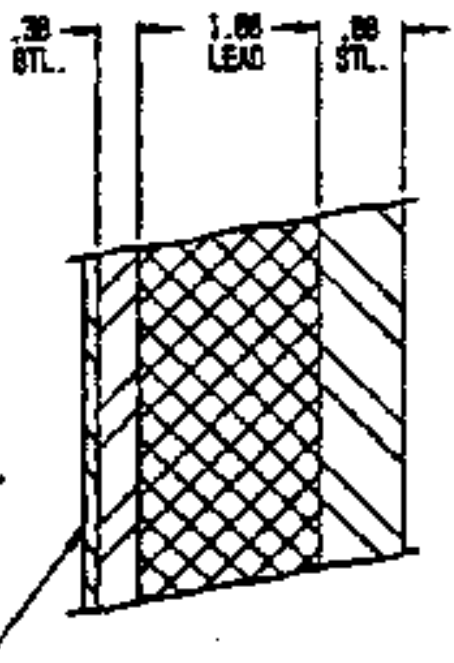

30 at ung

SHRPEING CONFTERATIOHS

\begin{tabular}{|c|c|c|c|}
\hline Shipping Contiguration & KO. & Capacity & Max Rad Lavel \\
\hline 5s-gुal1on Dritim & 14 & $55 \mathrm{Gal}$. & 20 rew per hr \\
\hline 215 Inner & 1 & $\begin{array}{l}\text { Dath shetet } \\
\text { RT=27 }\end{array}$ & 20 rew per hr \\
\hline $\begin{array}{l}\text { RADLOK }-55 \\
\text { bigh Intogrity contatinge }\end{array}$ & 14 & Data shoet & 20 rem per hx \\
\hline $\begin{array}{l}\text { RADLOK }=195 \\
\text { Hitg Inting }\end{array}$ & $\overline{2}$ & $\begin{array}{l}\text { Data Sheet } \\
\text { BT=25. }\end{array}$ & 20 rew per ha \\
\hline
\end{tabular}

Trawing: STD-02-077

1sk Operating Procedures: \$50-8-02-020

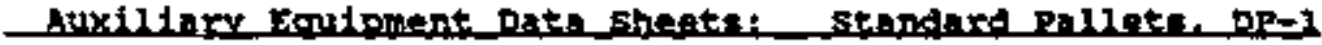

$\mathbf{E}-\mathbf{A}$ 
ACIEArIFIC SCOLOGY GROSP, IHC.

A Westinghouse Subsidiary

BADWASTE SHIPPTNG CASK DATA SHEFT
Data sheet No.

Rev. No.

Date

Reference

Approved

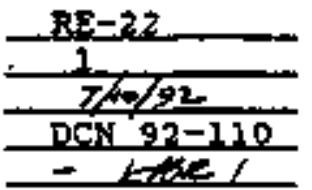

Model Designation: $14-215$ CAsK TN CIOSED TRANSPORT VEHTCIE (CTV-2)

USNRC Certificate No. USA/9222/A

Empty wgt: 44.000 lbe Hax Payload: 20.000 1bst shipping Wgt: 54,000 ,bs.

shielding: (Load Equizvalent)

*Indivisible Payload only- contact sEG for Additional Infornation

side wall Thickness $1^{\prime \prime}$ Maxinur

CTV Weight 5600 lbs Maximum

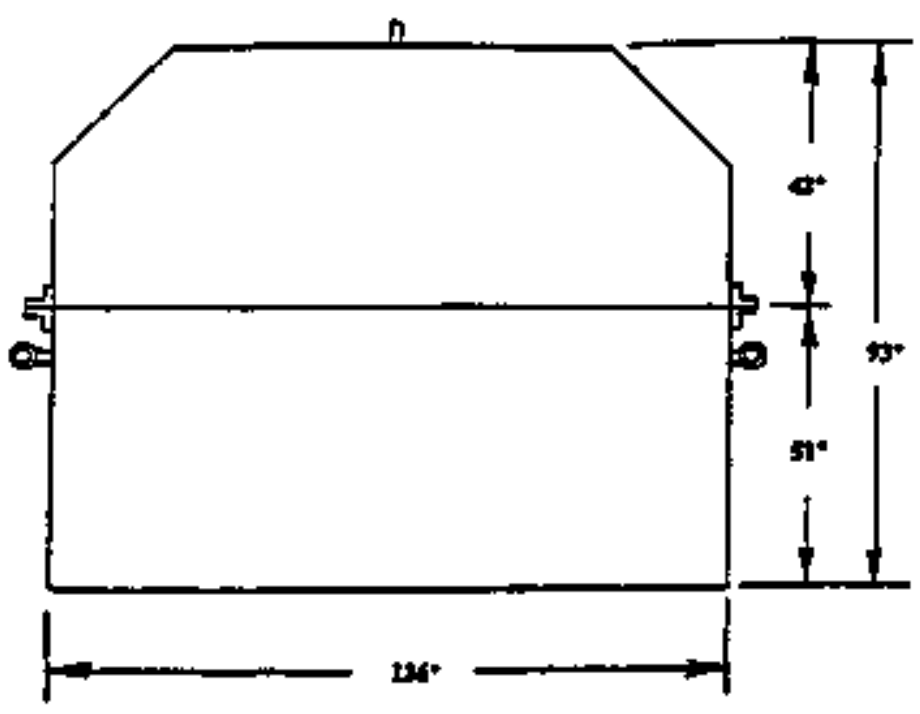

Side View
(0)

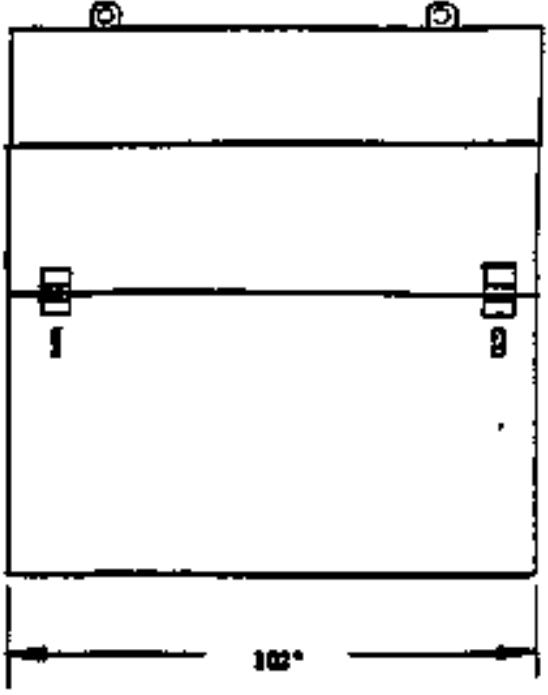

Fronc Viev

Reference Data sheet No. RE-13 tor \$4-215 Cask

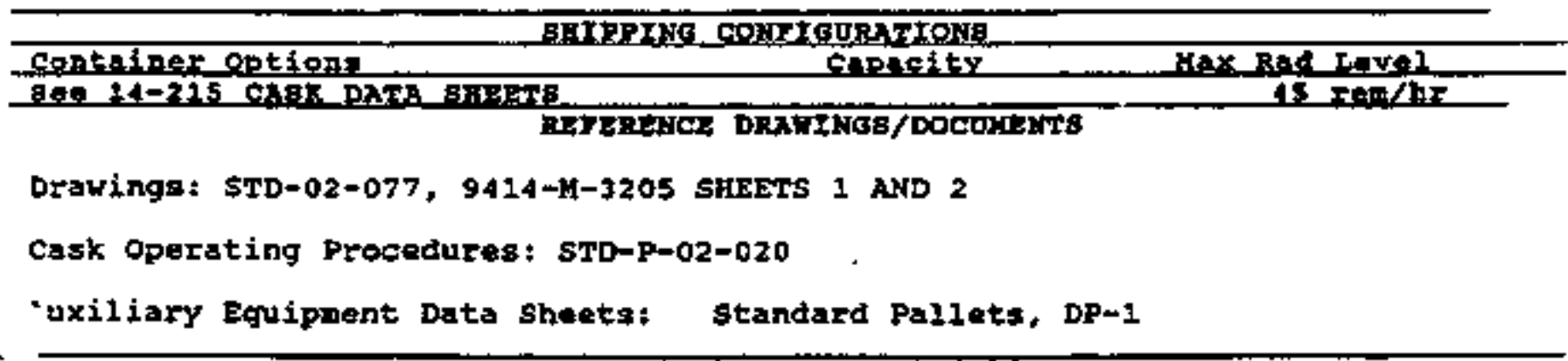




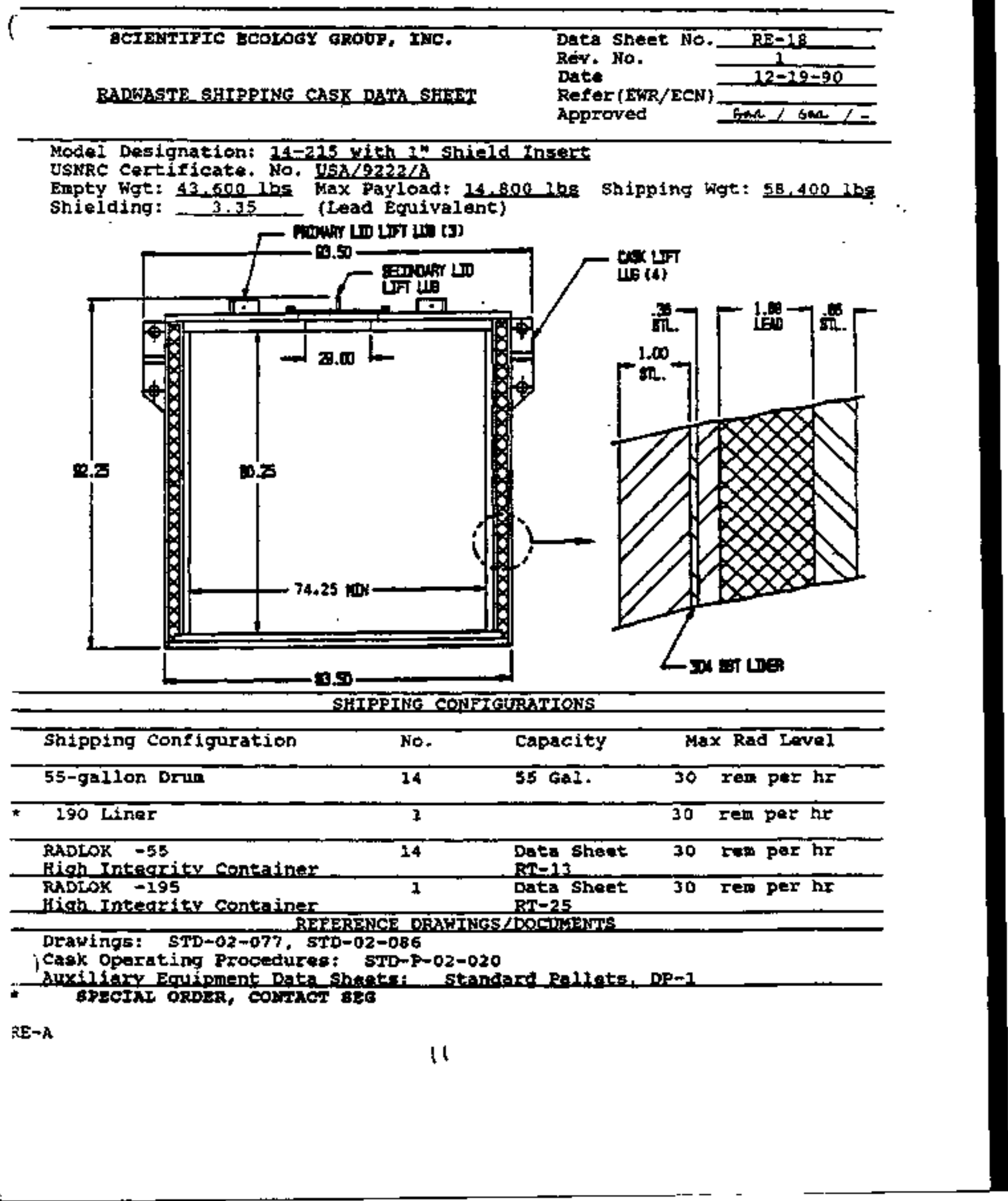




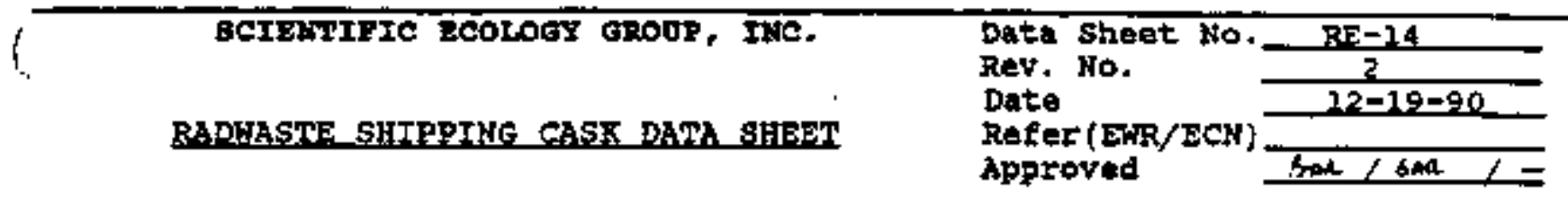

Model Designation: $14-215$ wdth $1-1 / 44^{*}$ shleld Insert

USNRC Certificate. No. tSA/S227/A

Eimpty Wgt: 43.000 lbs Hax Payload: 13,400 lbs Shipping Wgt: 58,400 1bs Shielding: $\frac{3.50}{30}$ (Lead Equivalent)

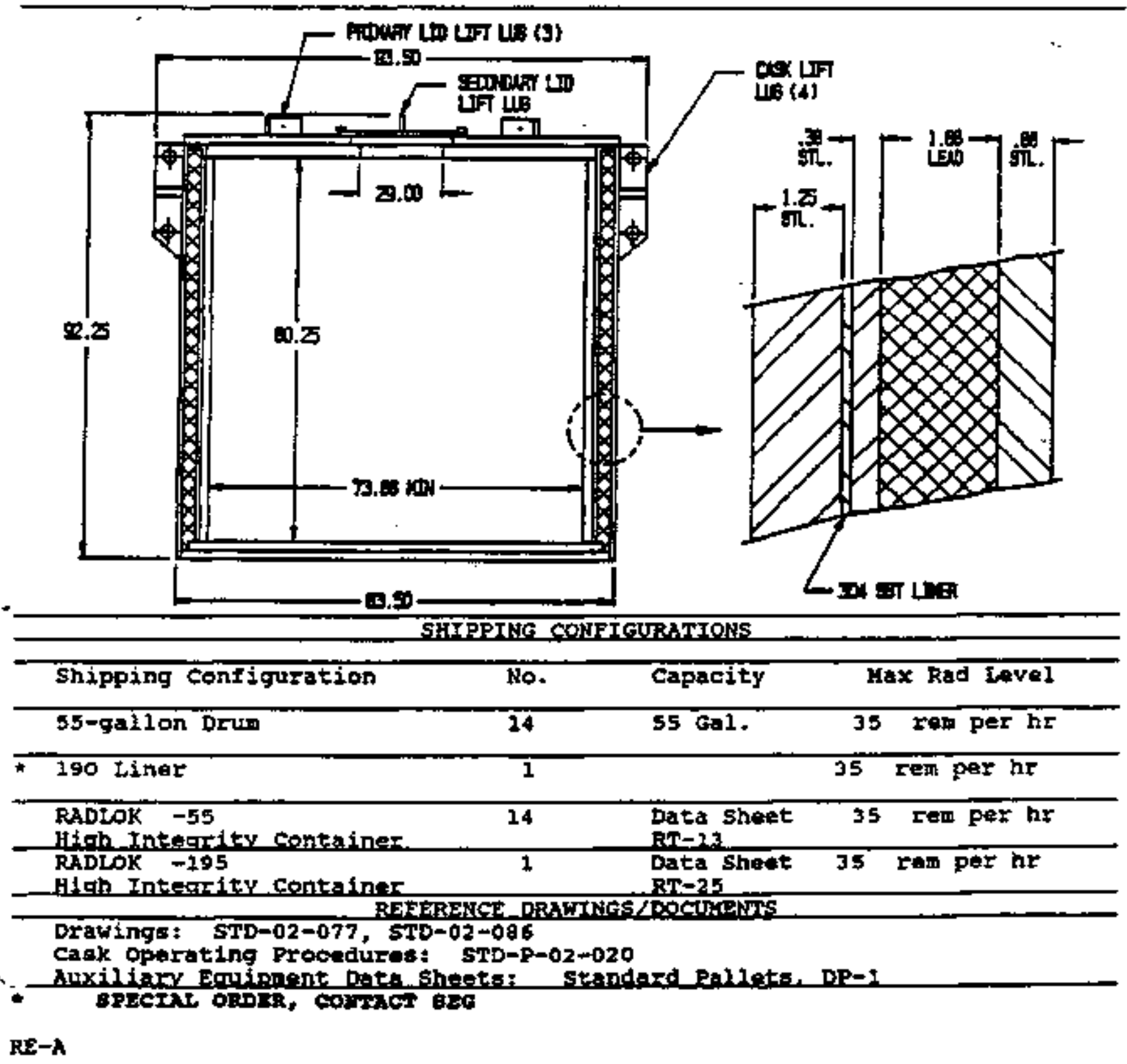


acrmiritie ncowory apots, smc.

BADAAST:_SHCPENG_CASK_DATA_SHFT
Date Sheet No. $R=1-4$

Rev. No.

Date

Refer ( $\mathrm{BT} / \mathrm{DCN})$

Approvod

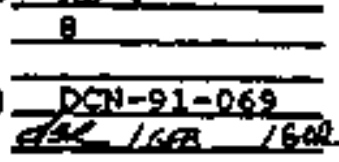

8EG Yobe2 Desigmationt 2-829

UsNRe certifleato. No. DSA/6574/BU1

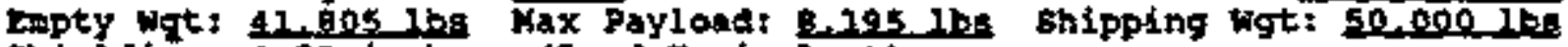
onielding: 4.58.1nches. (Laad Equivalent)

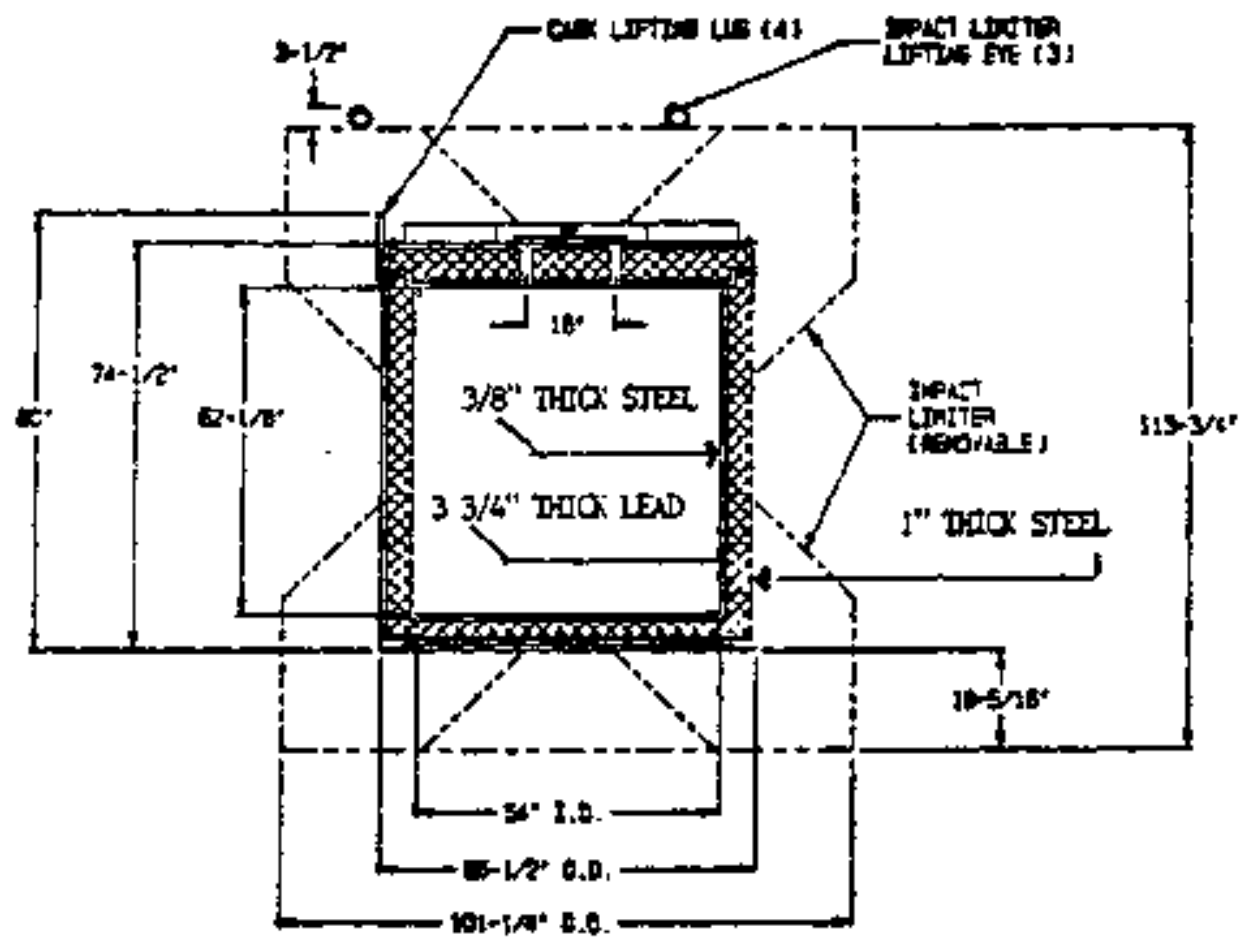

SHTPRIRG CONEIFURATIOHS

shipoing configuration

No.

capacity

Yax Rad Level

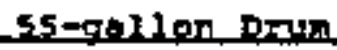

3

55 Gal.

1000 resinger he

176 standard stetel riner

Date Shent. 800 rem per hr

RADLOX" -55

Hifh intage ity container

RADLOK -200

High integrity conteiner

Data sheet 1000 rap par hr

RT $=13$

Date shett 900 rem per hr

1

$\mathrm{nT}=2 \mathrm{~s}$

BEF MBACE DRSt

Draytinge: stD-0z-076, shekto 1-3

Cark Operating procedures: BFD-P-02-017 and 5FD-P-02-024

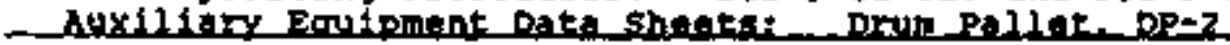


SCIEHTIPIC ECOLOEY GROUP, INC.

$\lambda$ Westinghouse subsidiary

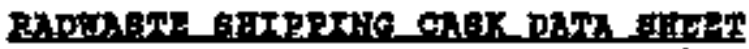

Data sheat No.

Rev.. No.

Dat:

Reference

Approved

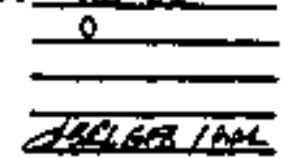

Modol pesifinetion: TH-142

Empty tat: 54.000 ibs

Shielding: $4.4^{*}$ (tad Endivalent)
USNRC Certiricate. No, USA/9073/A

Max Payload: 10 , 000 lbs

Shipejing flat: 64,000 iths

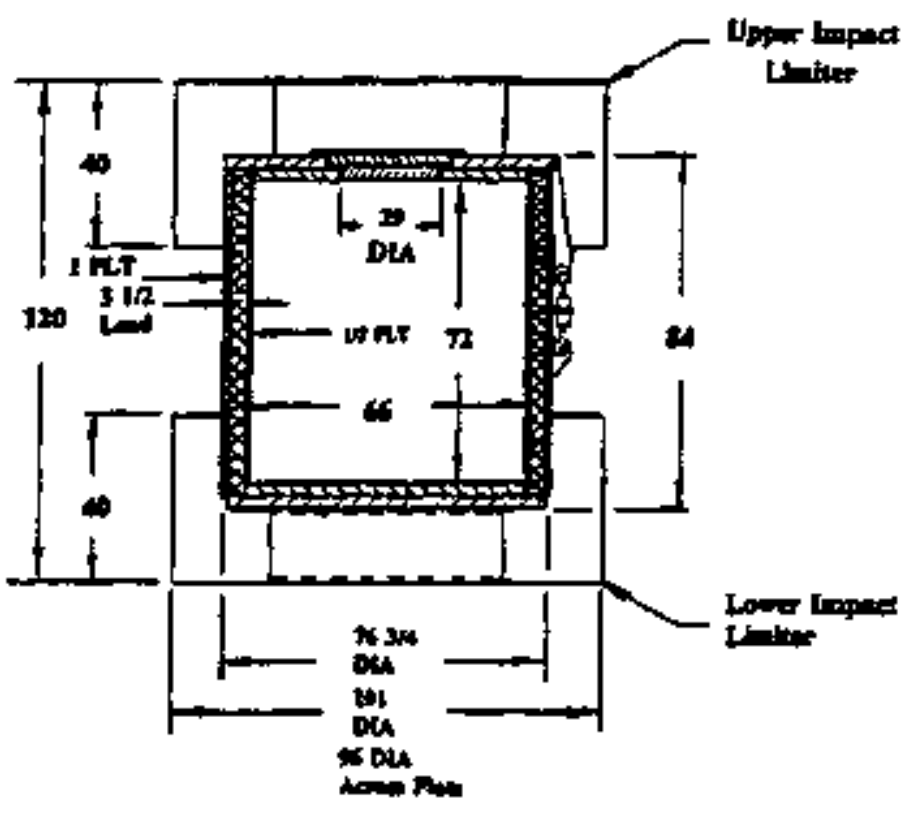

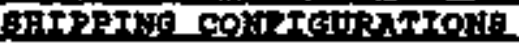

\begin{tabular}{|c|c|c|c|}
\hline shipping Configuration & No. & Capacity & Max RaA Ievel \\
\hline 55-Galion Dewim & 10 & $55 \mathrm{Cal}$ & 350 ren per $h r$ \\
\hline+14211 ter & 2 & Contact SEG & 350 rem par $h r$ \\
\hline $\begin{array}{l}\text { Barrier Plus } 131 \mathrm{C} \\
\text { High Integrity Container }\end{array}$ & 1 & $114.3 C F$ & 350 Iam par hr \\
\hline $\begin{array}{l}\text { RADLOK-500 } \\
\text { High Integrity conteiner }\end{array}$ & 2 & $\begin{array}{l}\text { Deta sheet } \\
\text { RT-17 }\end{array}$ & 350 red per hr \\
\hline
\end{tabular}

Drawings: 9414-1-3204

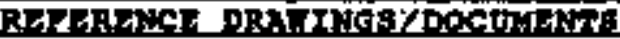

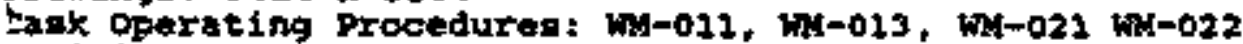

Aux 1 igry Equipount Data stherts: standard Fallets, DP-4

- Special ordar, contact seG 


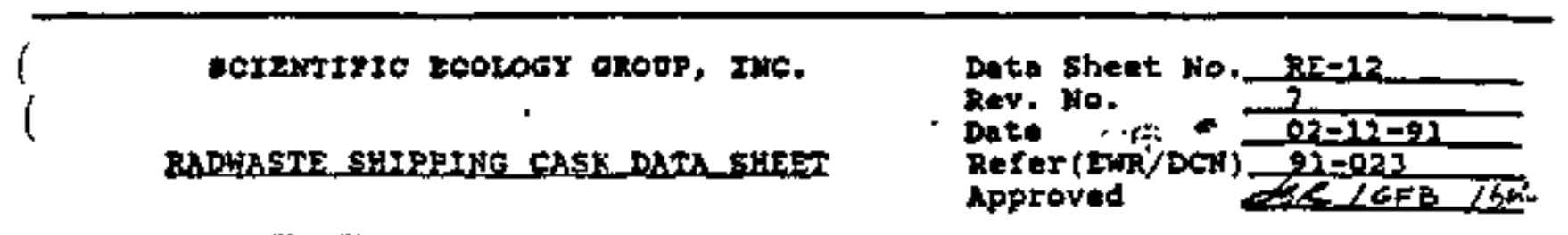

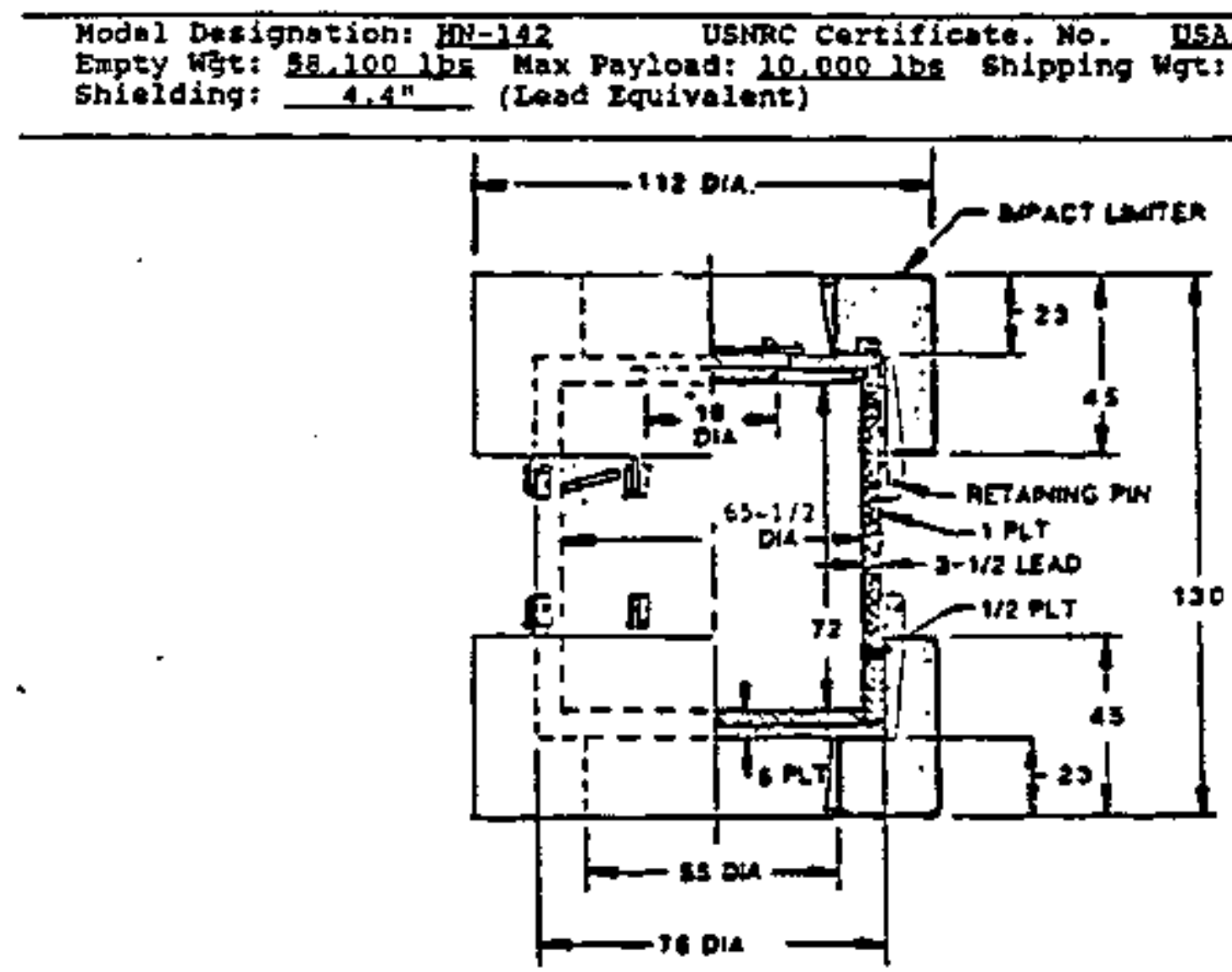

SHIPPJNG CONEIFIRATIONS

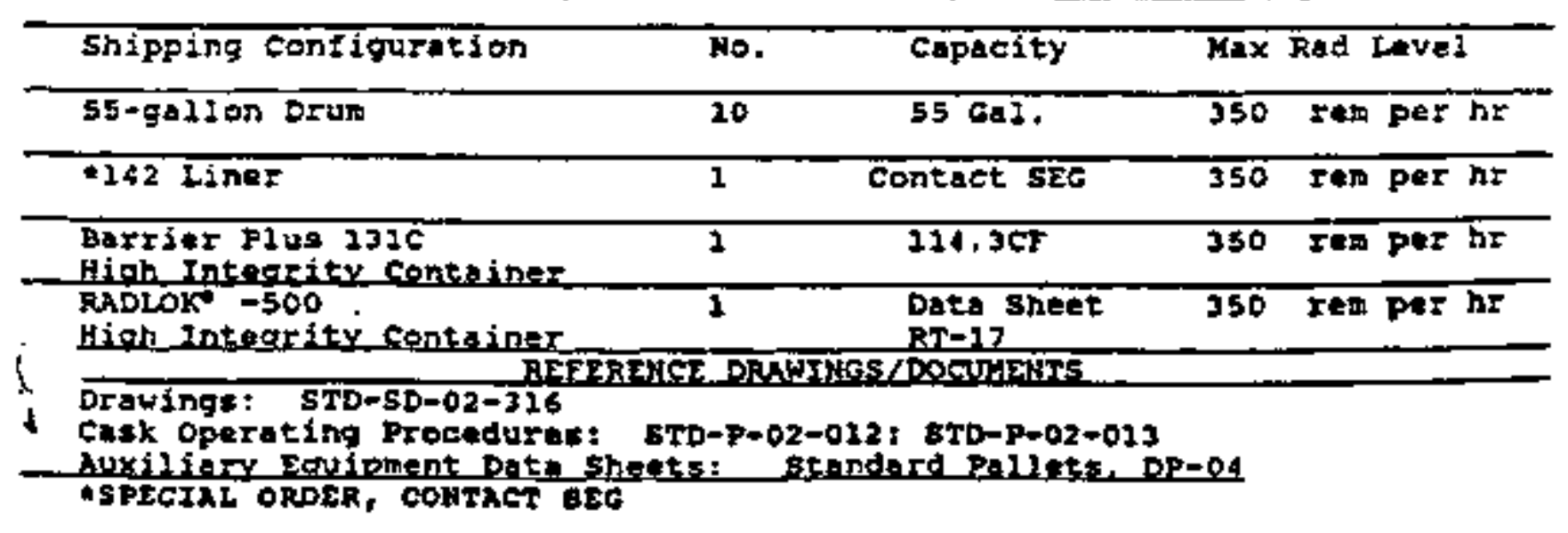

Rt-A 


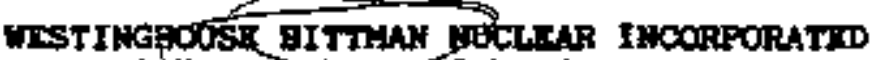

$A$ Weation howe Subsidiayy

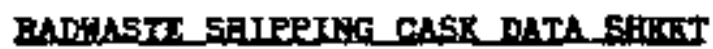

Data Shet No.

Rey. No.

Dete

Refer ( ITR/ECN)

Approved $\Lambda$ A

Hittman Hodel Deslemation: Elit-190-1

USNaC Certiflcete No. TSh/gnafle

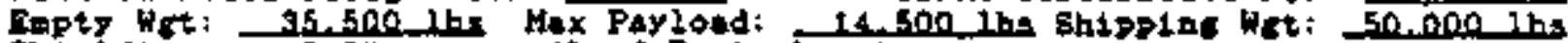

Shitiding: - $2 \mathrm{~s}^{4}$ (Lead Equivaint)

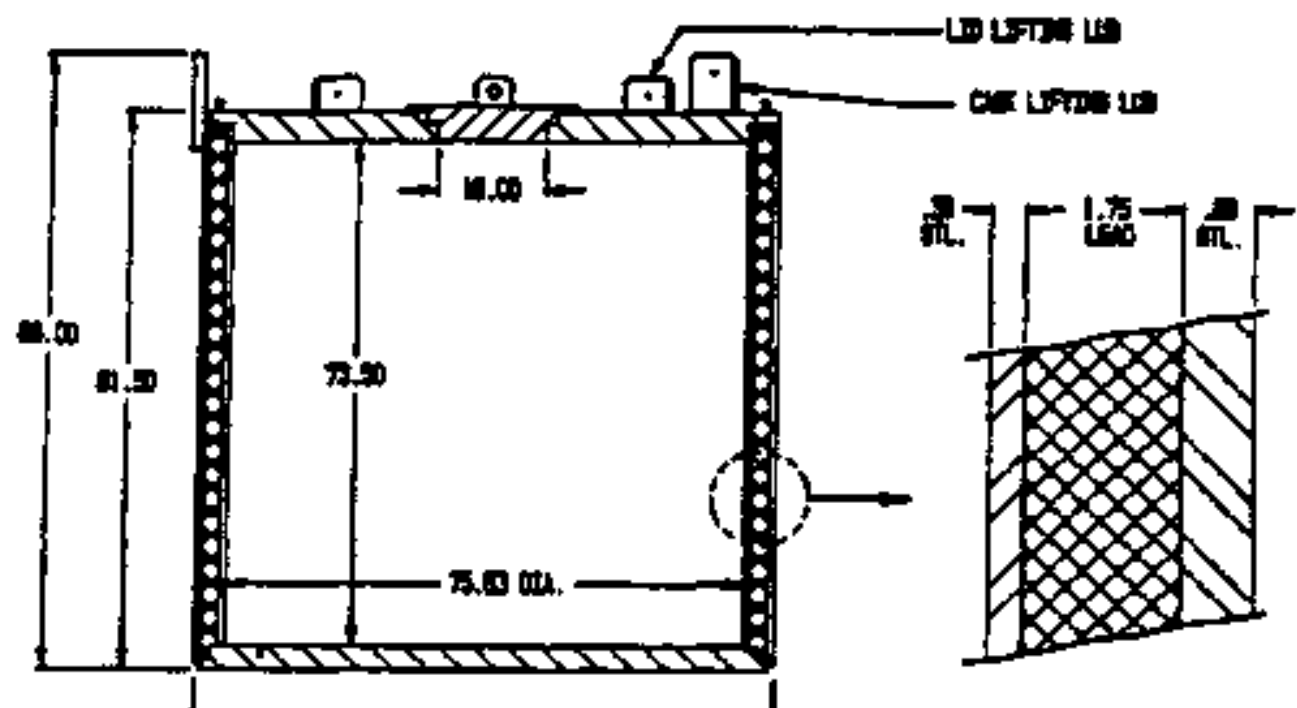

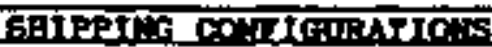

Shipping Conficuration

Crpecity

Rof oronce

Hex/AvE Rind Level

\begin{tabular}{|c|c|c|c|}
\hline 55-stilon Drum & 74 & -+- & 15/8 red per hr \\
\hline 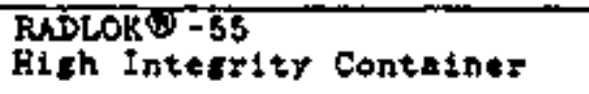 & 14 & $\begin{array}{l}\text { Data sheet } \\
\text { Ric }=3\end{array}$ & $15 / 3$ rem per hr \\
\hline $\begin{array}{ll}\text { th-100 liner or } \\
\text { HN-100 Larqe Vol. (LV) Liner }\end{array}$ & 1 & $\begin{array}{l}\text { Datt shtet } \\
\text { RT-1 or } \mathrm{RT}-2\end{array}$ & $12 /=0$ rem per hr \\
\hline $\begin{array}{l}\text { RADLOK+100 } \\
\text { Hith Integrtty Contalner }\end{array}$ & 1 & $\begin{array}{l}\text { Dati Shedt } \\
\text { RT }=12\end{array}$ & $12 /=-$ rom per hr \\
\hline $\begin{array}{l}\text { Hk-600 Larde Vol. (LP) Liner } \\
\text { Stackable/Grapoble }\end{array}$ & $\bar{z}$ & $\begin{array}{l}\text { Data sheet } \\
\text { RJ-18 }\end{array}$ & 12/4 Iet per hr \\
\hline 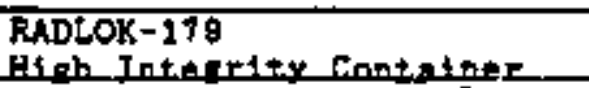 & 1 & $\begin{array}{l}\text { Data Ghoet } \\
\text { RT }=24\end{array}$ & $12 /=0$ ren per hr \\
\hline
\end{tabular}

Draw1ngs: STD-02-028, STD-02-029, and STD-02-030

Cask Operatine Procedure: STD-P-02-022

Auxiliery Equipaent Dato Sheets ; Standard Pollets. DP-1 
WESTINGHOUSE RADIDLOGICAL SERVICES, INC. A Wostinghouse Subsidiary

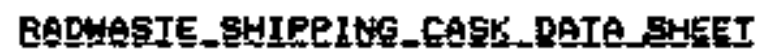

Data Gheet No.

Rev. No.

Date

Reter \{EWR/ECN\} "Tis

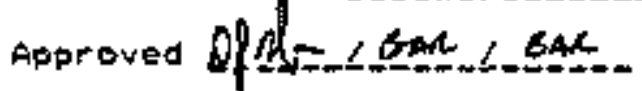

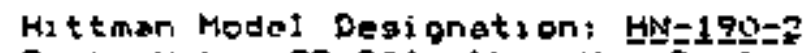

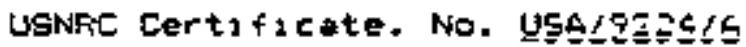

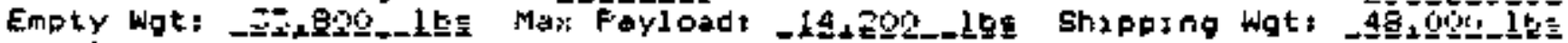

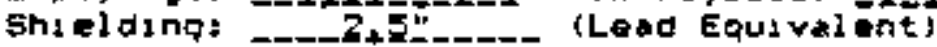

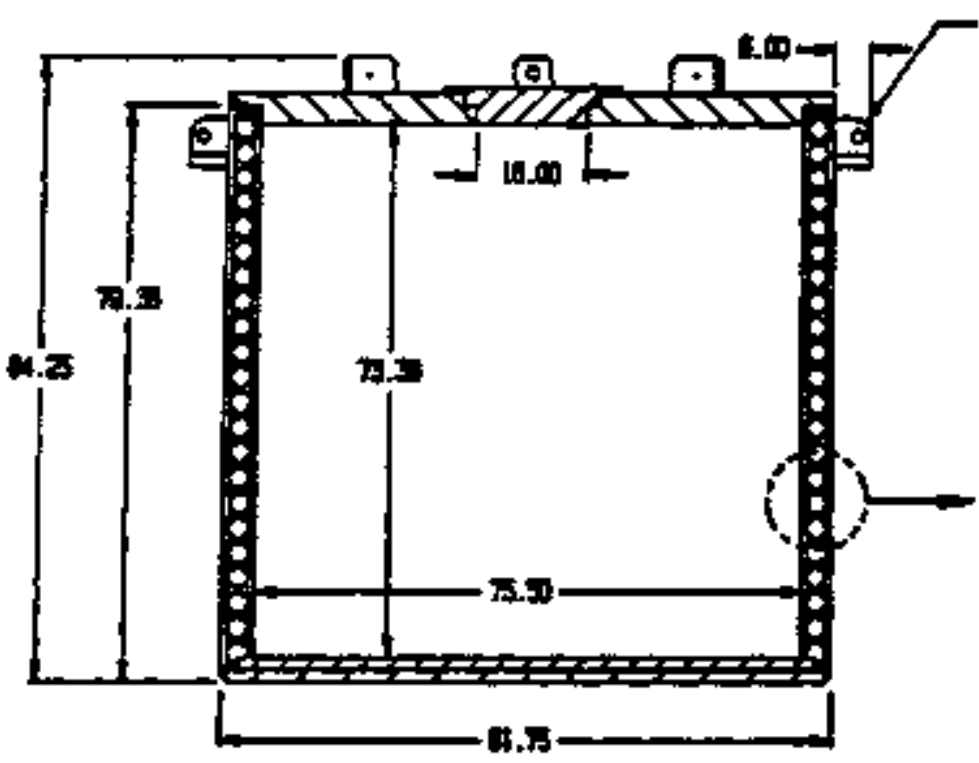

\section{T. 4 ins}

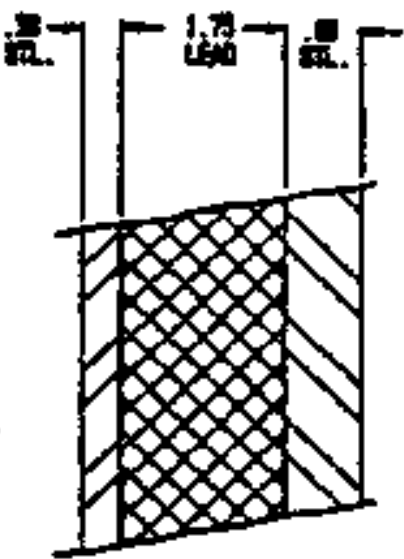

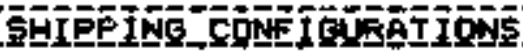

Shipping Confaguratior,

No.

EAFACIty

Ma:S/Arg Kad Ltrel

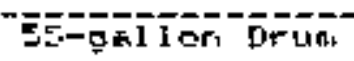

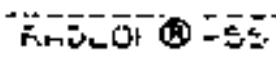

Hughi Integ-lty Eantiant

Hiv-1, tom or

HN-100 Laroe Vel. (LV) Laner

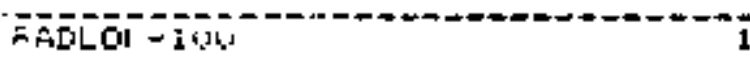

High Integrity Contabner

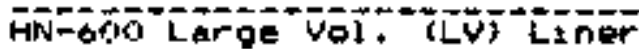

StoclablefGrappabl

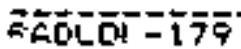

ion Integratr CONLAsmer
14

14

$\overline{1}$

$\overline{1}$

F:T-1 or RT-=

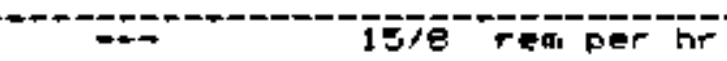

Deta Shét

FT-1:

-

rawings: 5TD-r, $=090,5 T D-12+001$, STD-02-08

a) Defratjrig F-OCedure: STD-F-6)-017

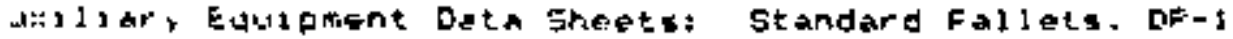


WESTINGHOUSE RADIOLOGICAL SERVICES, INC. $A$ Wotinghouse Subsidiary

RADWXSTE SHIPPING CASK DATA SAEET
Data sheet No. RE-9

Rev. No.

Date

Ref $z$ ( EWR / ECN )

Approvéd

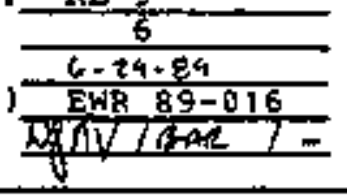

Model Designation: HN-100 Series 3 USNR Certiflaste No. USA/9151/A Eanty Wgt: 35,200 lbs Max Payload: 17,800, ibs shipplng Hgt: 53,000 lbs

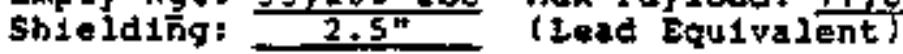

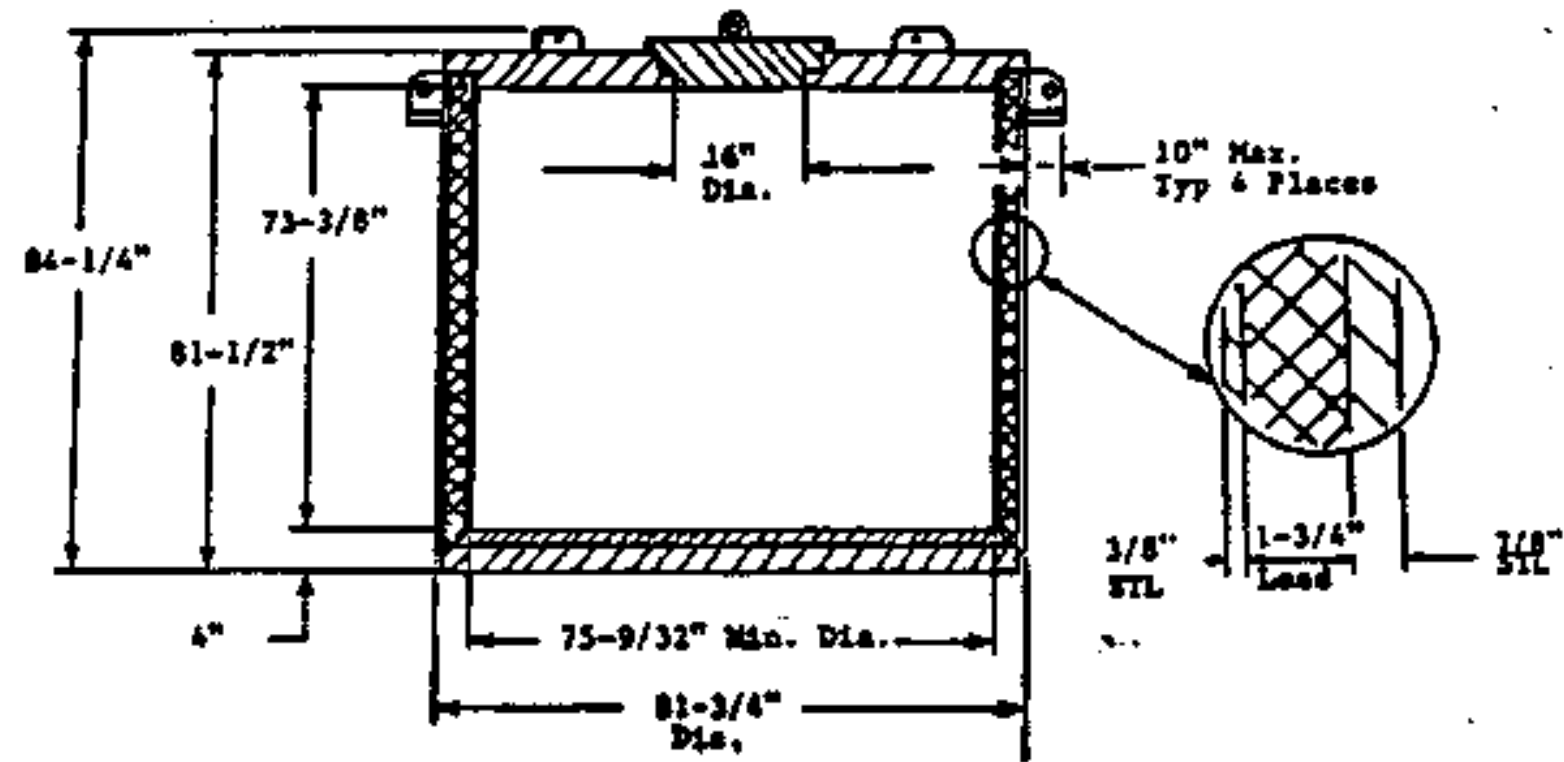

\begin{tabular}{|c|c|c|c|}
\hline \multicolumn{4}{|c|}{ SHIPPING CONFICUARTIONS } \\
\hline Sh1pping Configuration & Reference & Capacity & Max/Avg kad Level \\
\hline 55-galion Dram & $=--$ & 14 & 1578 rom par hy \\
\hline $\begin{array}{l}\text { HN-100 Liner or } \\
H N-100 \text { Large Vol. (LV) Liner }\end{array}$ & $\begin{array}{l}\text { Data sheet } \\
\text { RT-1 or RT-2 }\end{array}$ & $\mathbf{T}$ & $127-$ rea per hI \\
\hline $\begin{array}{l}\text { Hi-600 Large Vol. (LV) tiner } \\
\text { Stackablo/Grapdable }\end{array}$ & $\begin{array}{l}\text { Datid sheet } \\
\text { RT }=18\end{array}$ & $\overline{2}$ & $12 / 2$ rom per hr \\
\hline HN-190 Linet & $\begin{array}{l}\text { Data Shoot } \\
\text { RT }-26\end{array}$ & 1 & $12 /-x \in$ per hr \\
\hline $\begin{array}{l}\text { RADLOK } 8 \text {-55 } \\
\text { High Integrity Container }\end{array}$ & $\begin{array}{l}\text { Dota Sheet } \\
\text { RT }-13 \text {. }\end{array}$ & $\sqrt{4}$ & 5 $/ 8$ rem per hr \\
\hline $\begin{array}{l}\text { ANDLOKG-100 } \\
\text { Figh Integrity contushet }\end{array}$ & $\begin{array}{l}\text { Data sheet } \\
\text { RT-12 }\end{array}$ & $\mathrm{J}$ & $127-500$ per hr \\
\hline $\begin{array}{l}\text { RADLOKOo -179 } \\
\text { High Integrsty Contalner }\end{array}$ & $\begin{array}{l}\text { Data Sheet } \\
\text { RT }=24\end{array}$ & $i$ & $12 /=$ refr per hr \\
\hline
\end{tabular}

Draw1ngs: CoO1-5-913日; Co01-5-9139; C001-5-9140; C001-5-9141; C001-5-9142; $\cot t-5-9143 ;$ and $\cot 1-5-9+44$

Cack Operating Procedures: STD-P-02-018

Auxdilary Equipment Data Sheets: Standard Pallet 
WESTINGHOUSE RADIOLDGICAL SERVICES, INC. A Westinghouse stbsidiary

\section{RADWASTE SHIPPING CASK DATA SHEET}

Data Sheat No. RE-10

Rev. Ho.

Date

neter ( EWR/ECN ) EWR Bg-016

Approvid

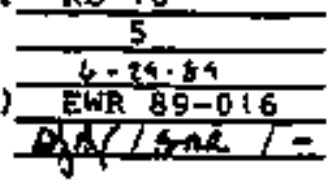

Model Dosignation: AN-100 Serles 3 Cast vith Shield Incert

USNRC_Certiflcate No. USA/9151/A

Empty Wgt: 42,445 ibs Tox Payload: 10,553 ibs Sh1pp1ng Wgt: 53,000 1bs

Shiolding: $\frac{3.2^{*}}{2}$

(Lead Equivalent)

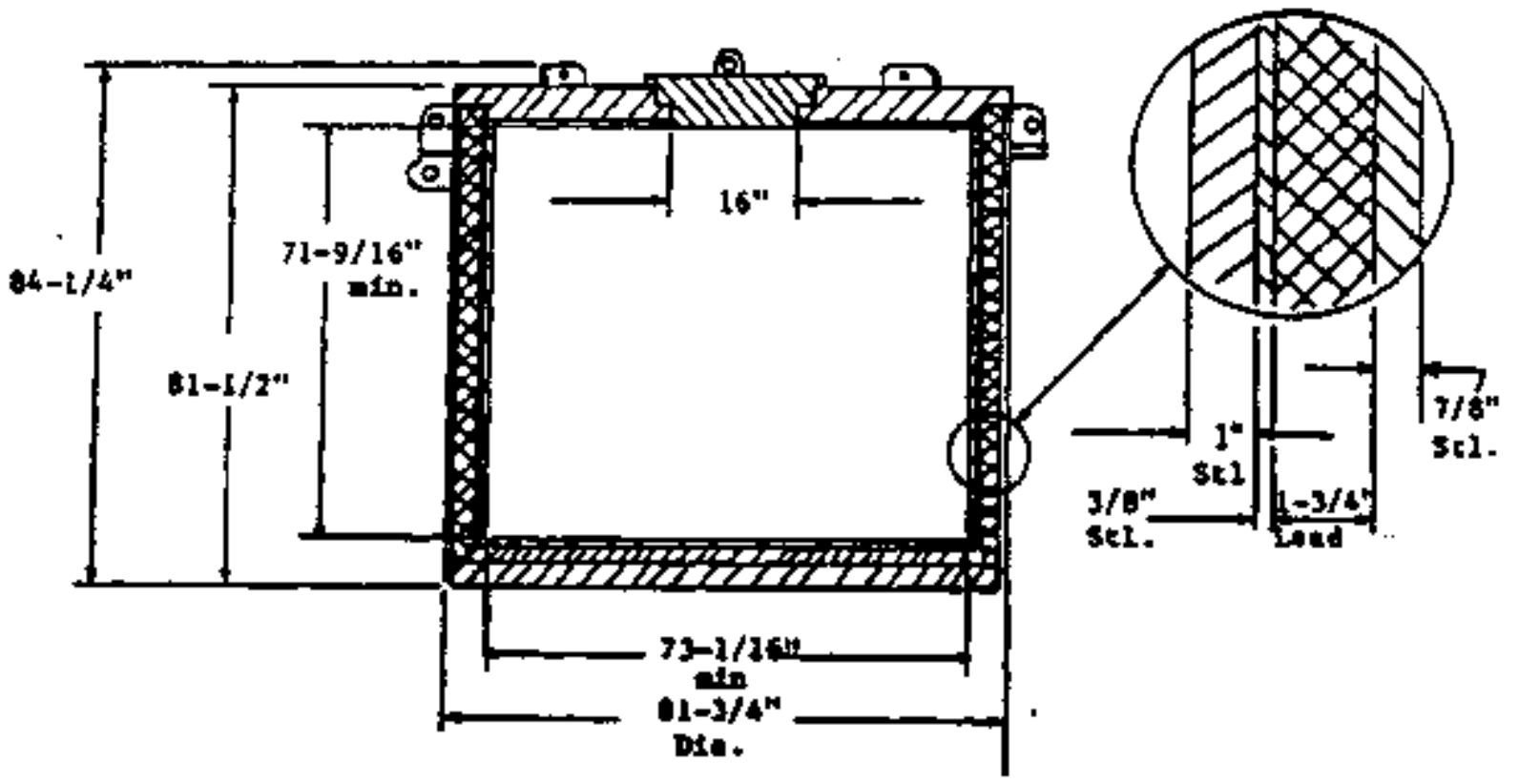

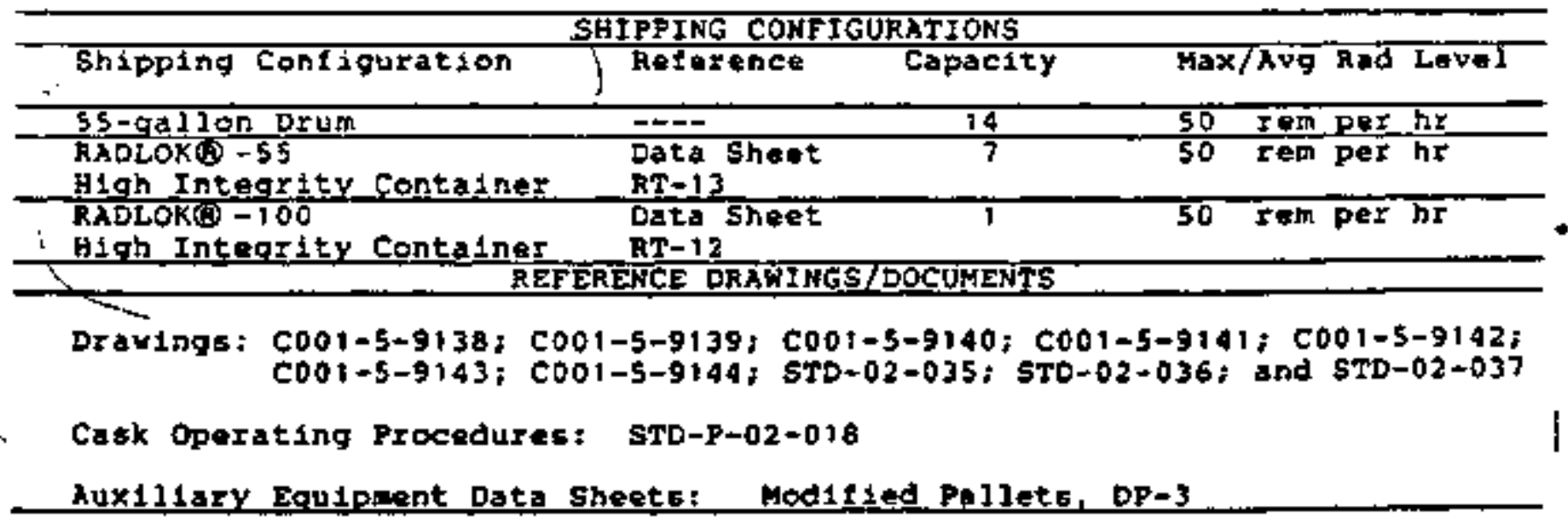


Beiontifle Ecology exoup, Inc. A Westinghouse subsidfsy

RADWASTE SHIPEING CASK_DATA_SBEET:
Data Sheet No.

Rev, No.

Date

Reterence

Approved

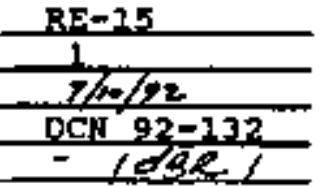

Model Destgnation: HN-300 Series 3 Cask with shield Insert in closed

USNRC Certiflcete No. USA/9151/h

Empty Wgt: 51 . 045 lbs Hax Payload: 10.55g 1bgt shipping Wgt: 61.600 2bs

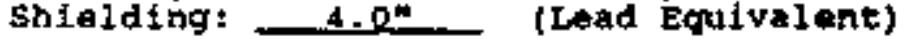

Indivisible Payload oniy- contact sec for Additional Information.

Side Wall Thickness 1" Maximus

CTV Weight 8600 lbs

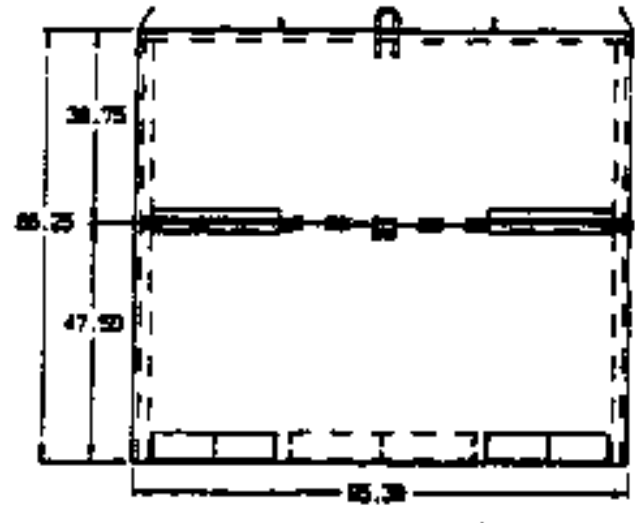

ERONT VIFH CTE

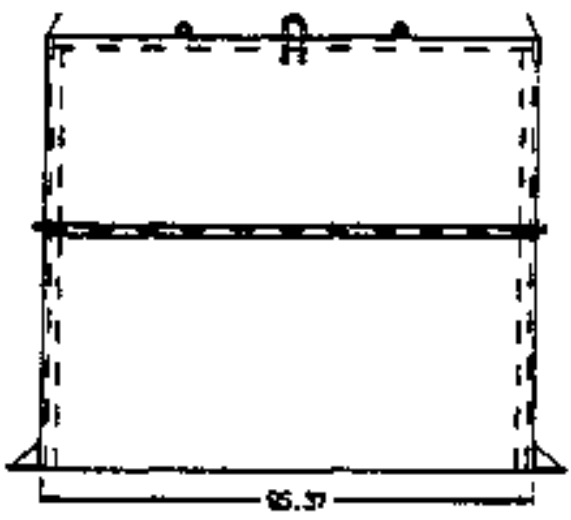

STDE UTA CWH

Reference Data sheat No. FE-10 tor Hi-100 Series 3 Cask with shield Insert Data

SHFPRTKG CONEIGURATIONS

Shipping coneiteutation

FADLOK -100

Retertent:

Deta shoet

RT-12

Hiah Integrity container
Max Rad Lava?

75 rew per hr

RTFERENCE DRANTHGS/DOCLNYENAS

Drawings: $\operatorname{coo} 1-5-9138 ; \cos -\$-9139 ; \cos 1-5-9140 ; \cot 1-5-9141 ; \cos 1-5-9142$; c001-5-9143; C001-5-9144; STD-02-035; STD-02-036; and STD-02-037

Cask operating Procidures: \$TD-P-02-018 \& CTV operating Procedure Auxiliary Equiphent pata Sherets: Moidlfied Pallets, DP-3 
Appendix B-2

Chem Nuclear Cask Data 


\title{
TCLECOPY TRANSMITTAL
}

TELECOPY SENT TO:

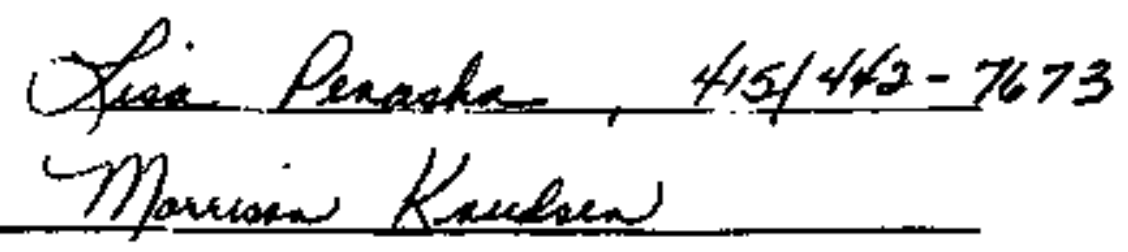

SEMT BY:

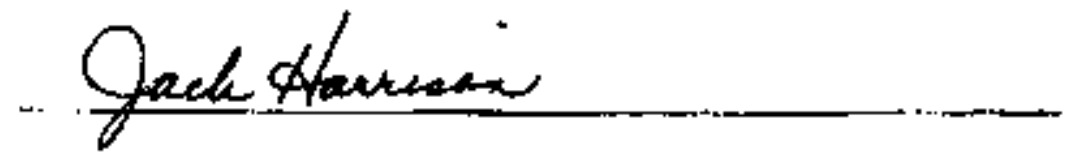

CIEEM-NUCLEAR SYSTEMS, INC. - MIDHEST OFEICES

1E. EPIAONE: (B15) 467-3000 (TO VERIFY).

(B15) 467-4646 (FELECOPIER)

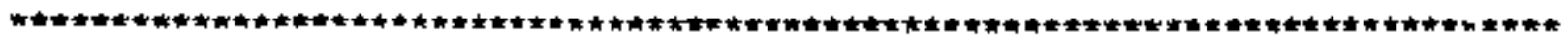

NUMBER OF PAGES SENI (INCLUDING THIS TRANSMITTAL COVER SHEET:

5

DATE: $2-16-93$

OPERATOR :

Q 4

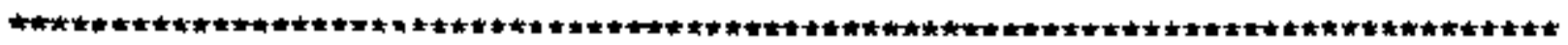




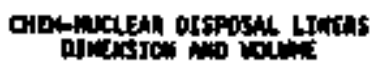

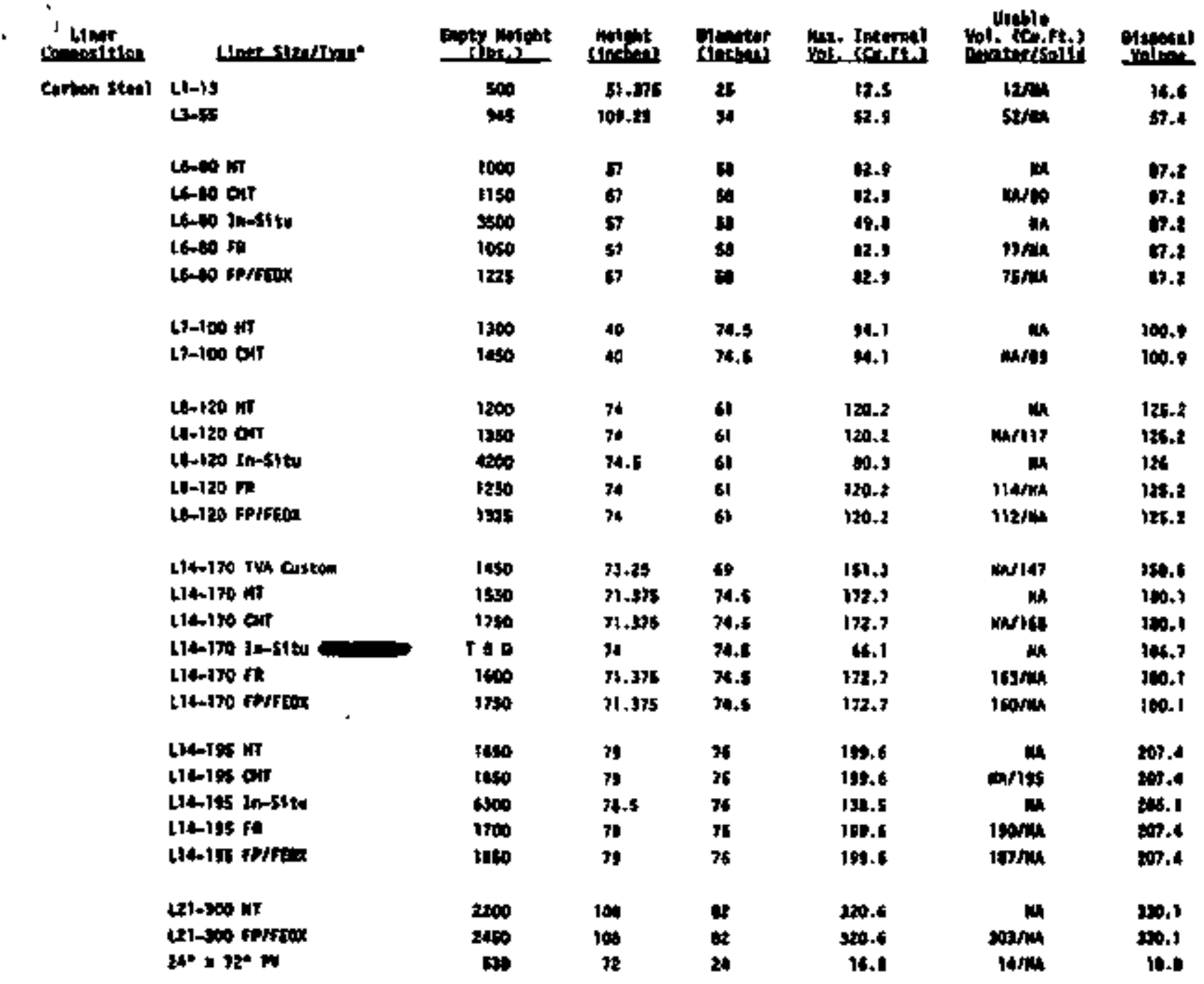

Wrat: Stwi tinyrs

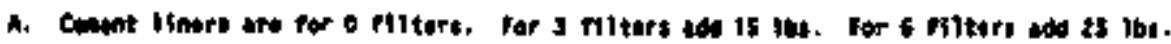

1. For ranate grapla rinut add:

c) 14-19s -9161.

ration - 115.

$10120=24 \mathrm{ks}$.

$7=100$ - 91165.

6- 40 - 21 165.

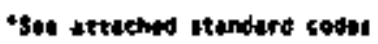




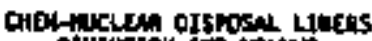
of

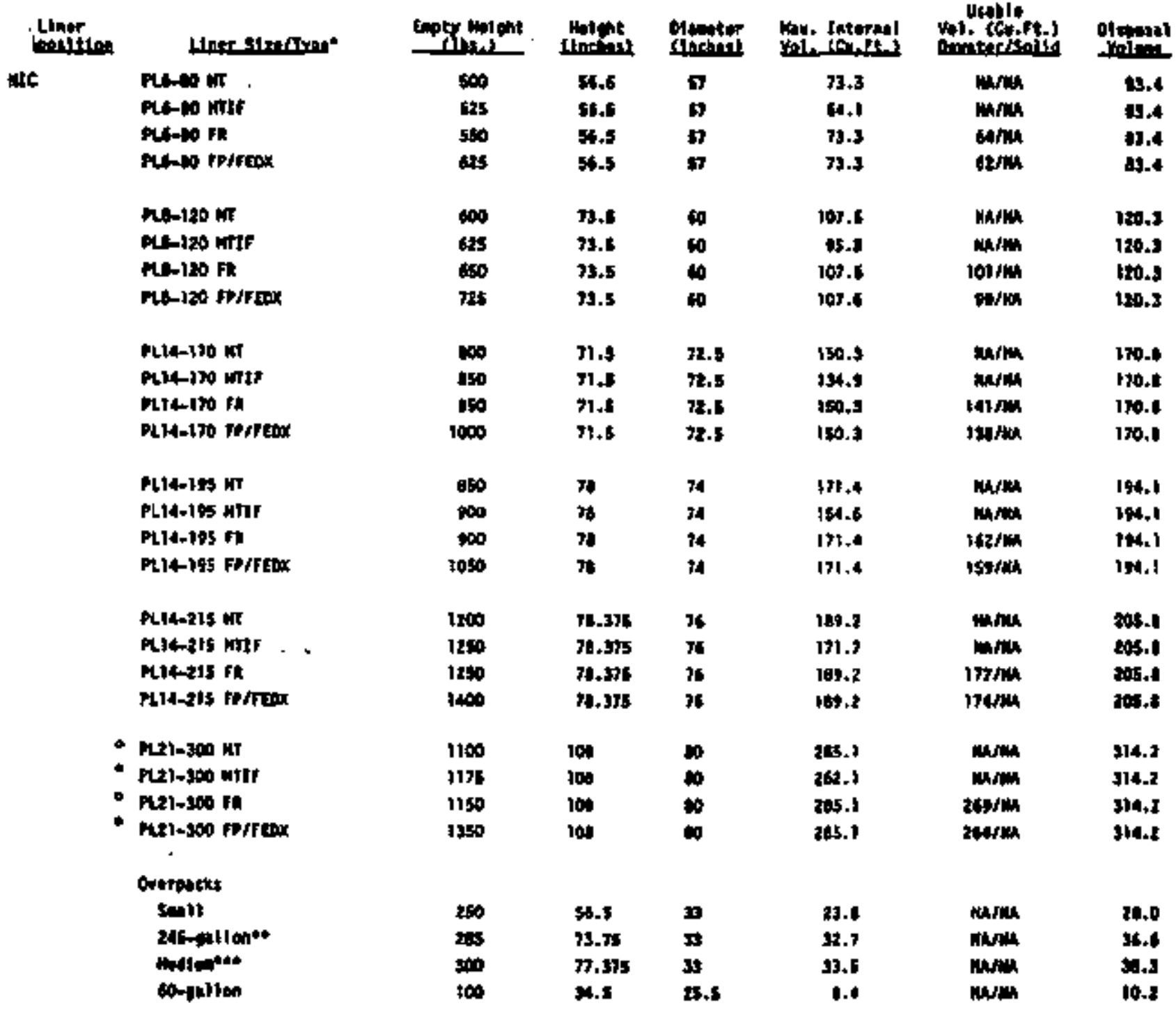

notr: nist

A. To renote grapold basket atd:

- Iagd tha in minimum of $81 \times$ weeks. 


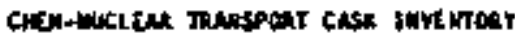

\begin{tabular}{|c|c|c|c|c|c|c|c|c|}
\hline $\begin{array}{l}51 \\
\text { insport } \\
\text { vintivfe }\end{array}$ & $\begin{array}{l}\text { ELASS]fJATIA } \\
\text { [ of } \mathrm{C}\end{array}$ & 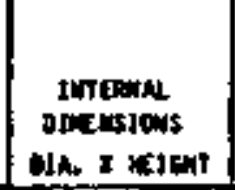 & 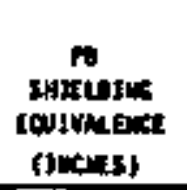 & 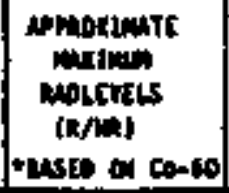 & 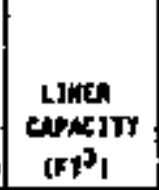 & $\begin{array}{l}\text { boing } \\
\text { [5s exty } \\
\text { coletry }\end{array}$ & 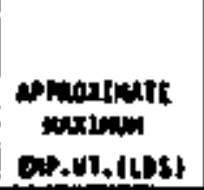 & 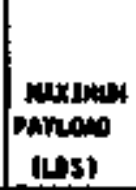 \\
\hline$; 1+0$ & uswisopors & $24^{*}=34.50^{\circ}$ & w1 & 0.200 & 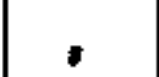 & $\mathbf{l}$ & 20 & sto \\
\hline ; $1-136$ & wre & $26.10^{\circ} \times 34^{\circ}$ & 6.20 & 6,000 & 13 & 1 & $20,030^{k^{4}}$ & 5,000 \\
\hline $1=1 x$ & $\begin{array}{c}\text { Tyon } \\
\text { usivion } n\end{array}$ & $2.50^{\circ} \times 64^{\circ}$ & c.70 & $4, \operatorname{sen}$ & 13 & 1 & 20.95 & 5,000 \\
\hline $\begin{array}{c}3.55 \\
-67-45 t\end{array}$ & $\operatorname{Ty}^{2}$ & $96^{*}=116.75^{\circ}$ & 7.00 & 15,000 & 60 & $\mathbf{z}$ & 64,400 & 0,420 \\
\hline 1446 & USt & $40^{*}=100$ & 3,30 & 60 & $n$ & 4 & 40,340 & 5.200 \\
\hline $\begin{array}{c}6-75 \\
-33-905\end{array}$ & $\begin{array}{c}\text { sert } 7 h \\
\text { ustoloth }\end{array}$ & $53^{\circ}=14.50^{\circ}$ & $4, \infty$ & 160 & ab & 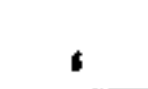 & 31.000 & 10,300 \\
\hline $640-1$ & 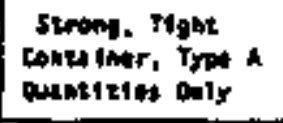 & $\omega^{\circ} \times \mathbf{4 0}^{\circ}$ & 6.00 & $\begin{array}{l}\text { Hert then } \\
\text { l Whr an } \\
\text { concet }\end{array}$ & as & 6 & $47,500 \mathrm{ktc}$. & |tratt \\
\hline $\mid-\infty-2$ & 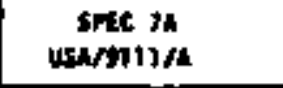 & $59^{*} \geq 50^{\circ}$ & $5 . \infty 0$ & 1,000 & 45 & 4 & 4,000 & 3.60 \\
\hline$t-10 t$ & $\begin{array}{c}\text { sefe in } \\
\text { usarbisteda }\end{array}$ & $24^{*} \times 185$ & 3.20 & 60 & $\mathbf{W} / \mathrm{h}$ & 6 & 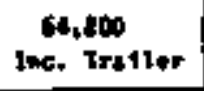 & 1,000 \\
\hline 1.100 & & $75.50^{\circ} \times 40.75^{\circ}$ & $3, \infty$ & 100 & $4+300$ & $\mathbf{T}$ & 35.500 & 13,000 \\
\hline $\mid \begin{array}{c}4-120 \\
0-100\}\end{array}$ & tren & $62^{*}=75^{*}$ & 1,00 & to & $120-130$ & $\bullet$ & 61.000 & 20,100 \\
\hline $12-100$ & 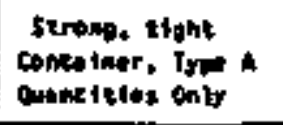 & $\sin ^{\circ} \times 40^{\circ} \times$ & $2 . \infty$ & $\begin{array}{l}\text { bot ton } \\
\text { Contert }\end{array}$ & $\boldsymbol{W}$ & 12 & 31,000 & $\lim _{101}$ \\
\hline $14-1)$ & ssereare/a & $75.60^{\circ} \times 73.25^{\circ}$ & 2.13 & 9 & pro-1as & 14 & 23,400 & 14,000 \\
\hline $\begin{array}{l}14-110 \\
\text { is } 171\end{array}$ & usarolsire & $75.50^{\circ} \times 71.25$ & 2.13 & $\bullet$ & $170-145$ & 14 & 3.,100 & 15,205 \\
\hline
\end{tabular}

Mag 1

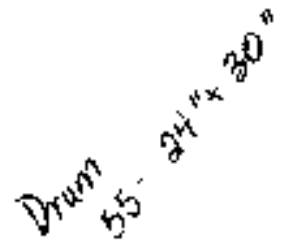




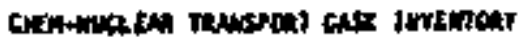

\begin{tabular}{|c|c|c|c|c|c|c|c|c|}
\hline 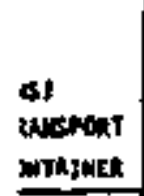 & 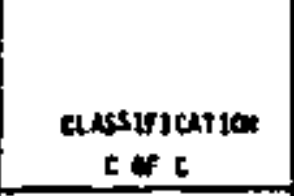 & 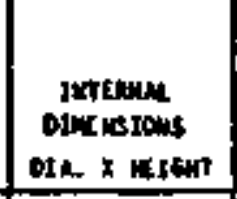 & 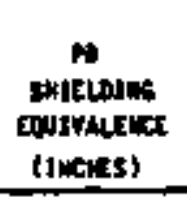 & 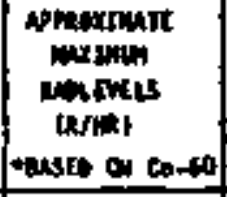 & 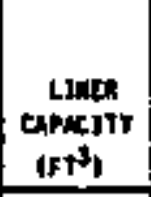 & 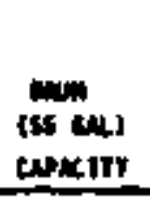 & 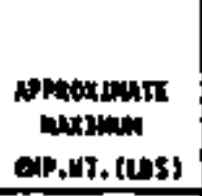 & 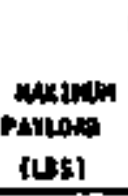 \\
\hline thateist & 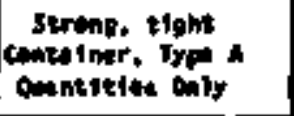 & $7 * x+\infty$ & 2.00 & 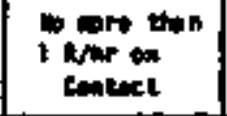 & 200 & 14 & 31,66 & 17.700 \\
\hline thatex & sotc 7h & $\boldsymbol{n}^{*}=\boldsymbol{s}^{*}$ & 2.28 & 16 & 194 & 14 & 3,400 & 17,700 \\
\hline 1-21s: & troted & $27.45^{*} \times 10.25^{\circ}$ & 2.73 & $\mathbf{a}$ & 105 & 10 & 3,000 & to, 0 cos \\
\hline $\begin{array}{l}151+-22 \alpha \mid \\
|(2)-240|\end{array}$ & 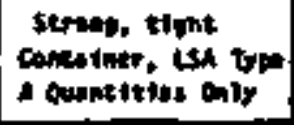 & 7..5* * & 1.25 & bere ben & 200 & 10 & 31,200 & Lim1 \\
\hline$x 515-t 605$ & 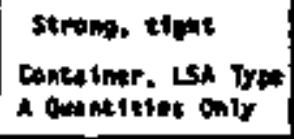 & $124 * 34^{*} x$ & 1,75 & 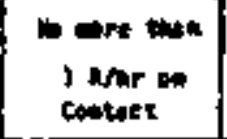 & $2 \bullet 00$ & 15 & 42,000 & tiol \\
\hline $1515-160$ & Typistar & $\underset{75^{*}}{126^{*}} \times 36^{+}=$ & 1.50 & 3 & $2 * 10$ & is & 31,000 & 5,000 \\
\hline $45 n-300$ & $\begin{array}{c}\text { stac } 2 h \\
\text { whisoswa }\end{array}$ & $1 x^{\prime}=100^{\circ}$ & 1.0 & $\mathbf{3}$ & 315 & 21 & 30,200 & 27,10 \\
\hline 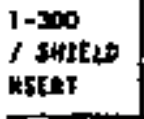 & 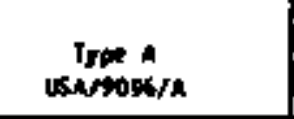 & $x^{*}, 100+1 / 2^{*}$ & 2,0 & 27 & 170 & 5 & 25,510 & n.teso \\
\hline LAT DEO & $\omega / \alpha$ & 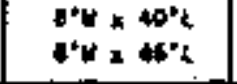 & $\Delta / A$ & 6 & $w / a$ & 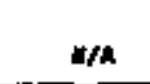 & 14,000 & 40,000 \\
\hline etentan & $\boldsymbol{m} / \boldsymbol{\mu}$ & 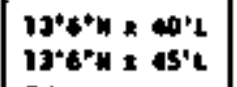 & $\mathbf{m} / \mathbf{a}$ & s. & $\mathbf{m} / \mathbf{a}$ & $y / 4$ & 17,500 & 45,000 \\
\hline atfors & 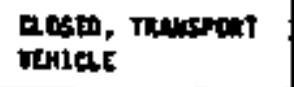 & $7+3^{+}$a $40^{\circ} \times+t^{\circ}$ & 0.6 & $\boldsymbol{H}$ & $\mathbf{M / 4}$ & 0.750 & $3,+\infty 0$ & 72,000 \\
\hline as $1 \mathrm{TC}-\mathrm{t}$ & 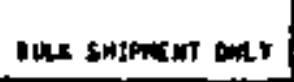 & ar, & Ine for the the & werest of ow bet & 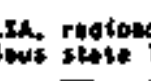 & tivesterter & 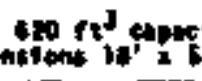 & ; \\
\hline ins tTC-s & STC & 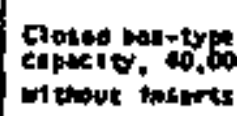 & 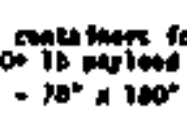 & 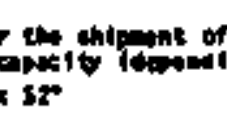 & 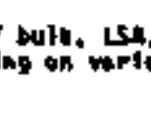 & roplowet & tites +40 & \\
\hline
\end{tabular}

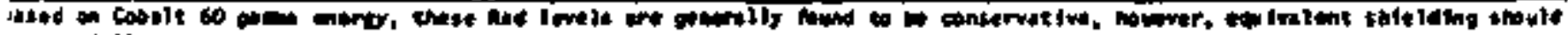

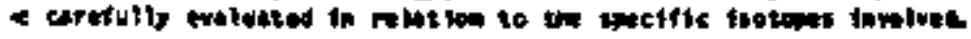




\section{Appendix B-3}

NuPac Cask Data 


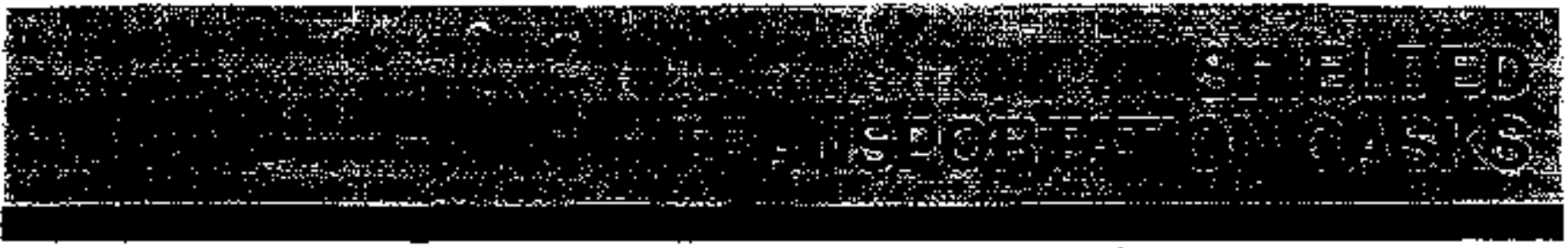

NRC-Licensed Type A and Type B Casks

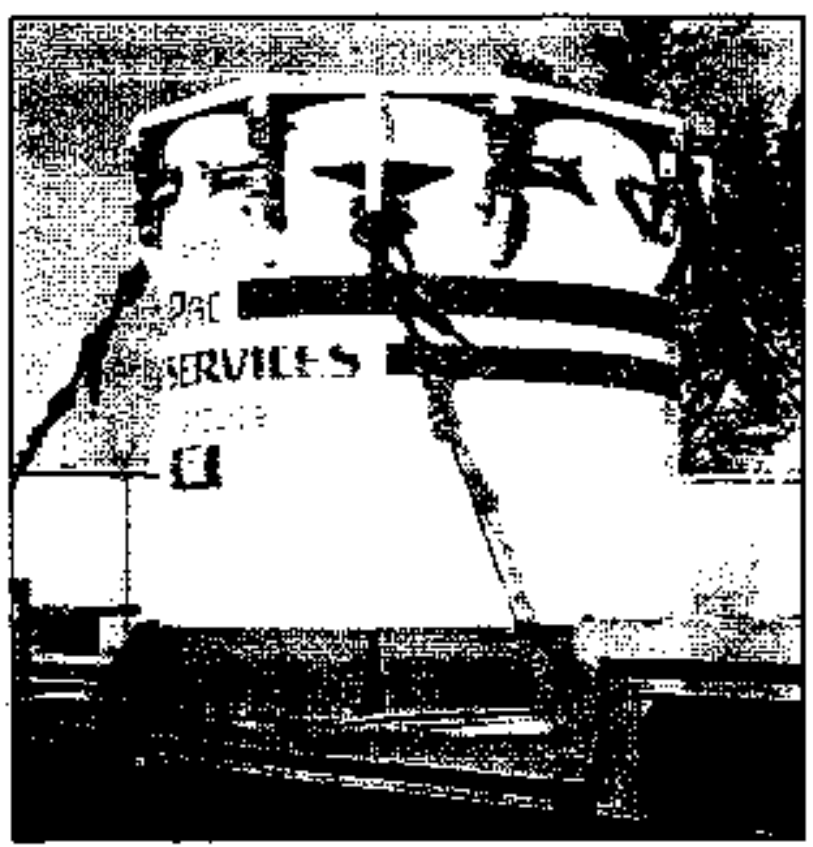

MODEL NuPac 14-210L Type "A' $\mathrm{C}$ of $\mathrm{C} 9176$.

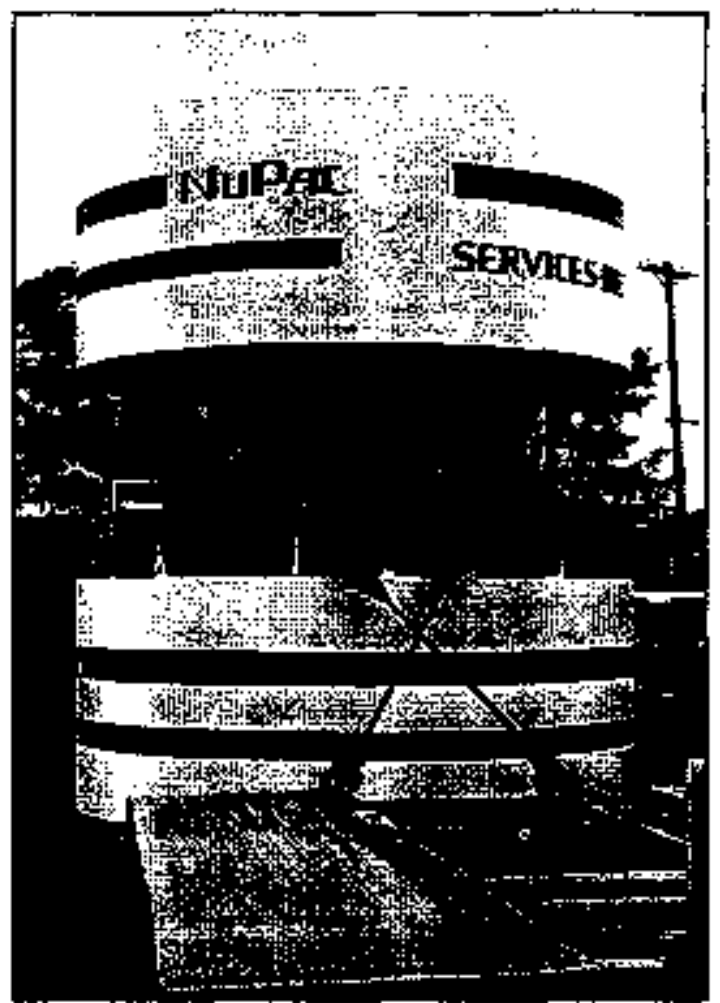

MOOEL NuPac 10-142 NAC Type " $\mathrm{AL} \mathrm{C}$ of C 9208

NRC-licensed Type A or Type B

- Full range of sizes for drums or bulk liners

- Shieldjing thickness from 1.5 to $4.4^{n}$ lead

- Rapid lid removal lowers operator exposure

- Designed and fabricated to NRC approved Q.A. program

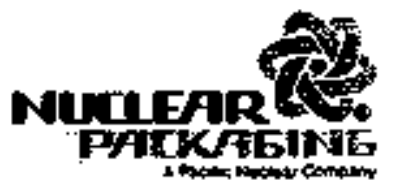


Nuclear Packaging, Inc. is America's largest suppligr of nuctear transportation anci handling equjpment. NuPac casks are used to transpert a variety of radioactive materials, from low-lowel waste to spent luel. We can design, license and labrlcate shielded transportation casks to fit your particular applicstion, Or, you may choose from our list of standard designis as shown on the tabie below. Typical design fealures include:

- High-strength, quick-acting binders secure the primary lid. This reduces poperator exposure and tum-arosind time by $50 \%$ over comentional bolting systems.

- Hightouallty epoxy pherolic paint and internal staindess steel hiner facilitates decontamination.

- Drain with extemal plug.

Chocse the cask that best fits your needt. Custum-deslgned tasks tan atso be provided.

\begin{tabular}{|c|c|c|c|c|c|c|c|c|c|}
\hline \multirow[b]{3}{*}{ Modor } & \multirow[b]{3}{*}{ 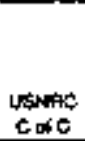 } & \multicolumn{8}{|c|}{ AXSGDORTA } \\
\hline & & \multicolumn{3}{|c|}{ COMONGTH } & \multicolumn{3}{|c|}{ 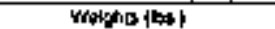 } & \multicolumn{2}{|c|}{ chenilrin.1 } \\
\hline & & $\begin{array}{l}\text { Dnum } \\
\text { Cop. }\end{array}$ & 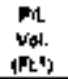 & $\begin{array}{l}\text { tood } \\
\text { End } \\
(j \times n)\end{array}$ & $\operatorname{Ermp} x$ & $\mathrm{PAC}$ & Lataded & $\begin{array}{c}\text { Wher } \\
\text { to } \\
A\end{array}$ & ${ }_{\mathrm{H}}^{\mathrm{msigh}}$ \\
\hline \multicolumn{10}{|c|}{ TRPE R EASKS } \\
\hline 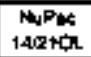 & 9176 & $\$ 4$ & 217 & 2.00 & 31.600 & 20.000 & 91.600 & 77.25 & 80.25 \\
\hline $\begin{array}{l}\text { Mappor } \\
\text { 14:2104 }\end{array}$ & m & in & רומ & $2, n$ & 38.406 & 20000 & 58,400 & 7.4. & 00.29 \\
\hline 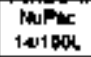 & 9159 & 14 & 190 & 2.00 & 87,700 & 80000 & 49.200 & 75.50 & T3998 \\
\hline 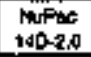 & 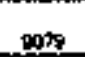 & 14 & 190 & 2.25 & 34,000 & 14.000 & 46,000 & 75,50 & 7.38 \\
\hline 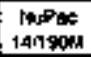 & 9 & 14 & 190 & 2.25 & 32500 & 20,000 & 93.500 & 73.50 & $7+38$ \\
\hline 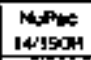 & 외용 & 14 & 190 & 3.50 & 43000 & 20000 & Ex.200 & 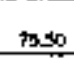 & fase \\
\hline 106060 & ent & . & 144 & 3,50 & $41.3 \times$ & 15.000 & $\operatorname{sis} s$ & s. & $73 x$ \\
\hline 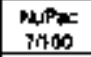 & 的 & 7 & 160 & $\mathbf{2 . 6 0}$ & $3 \operatorname{son}$ & 13000 & 4.200 & $\pi .50$ & 40.75 \\
\hline 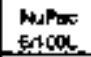 & 9178 & 6 & 185 & 325 & 30,00 & 13000 & 4,900 & 51,00 & $60 x$ \\
\hline $\begin{array}{l}\text { WWP: } \\
\text { El100\% }\end{array}$ & 91 조 & $\theta$ & 105 & 4.40 & $+1,200$ & 12,000 & 오, $\$ \infty$ & 81,00 & 요요요 \\
\hline 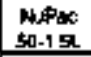 & 9145 & $=$ & 호 & 150 & SgDo & 4200 & 13.200 & $\neq 1.50$ & 됴툐묘 \\
\hline 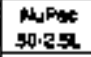 & g145 & - & 5 & $2 \$ 0$ & 15.000 & 4,700 & 19,200 & 4050 & 5850 \\
\hline $\begin{array}{l}\text { MuPat } \\
50-30\end{array}$ & $\$ 145$ & - & A & 9.04 & 18,0006 & 4,290 & 29,000 & 48,50 & 52.50 \\
\hline $\begin{array}{l}\text { Noliat } \\
50 \rightarrow a\end{array}$ & $\$ 145$ & - & 54 & 400 & 24,700 & 4,2006 & 28,900 & 48.50 & 5250 \\
\hline \multicolumn{10}{|c|}{ TYPEB BGAKS } \\
\hline 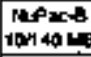 & $=$ & 16 & 155 & 1.25 & 59,000 & 15.000 & 58.000 & $86 \infty$ & 30 \\
\hline 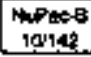 & son & 90 & 148 & 4.25 & $\$ 100$ & $\mathrm{FB}, \infty \infty \mathrm{O}$ & EtEET & 650 & $\tan x$ \\
\hline
\end{tabular}




\section{B-25 LSA WASTE CONTAINER

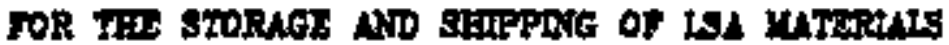

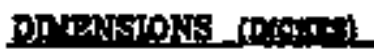

nitation.

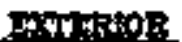

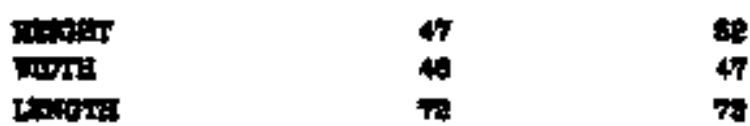

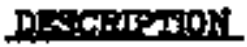

othetisstom

PMTRes THE

Dreatrit

1.4 ver companits.

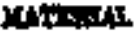

GA

to ouric $r+1$

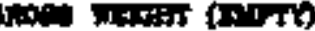

PArods

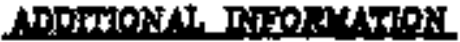

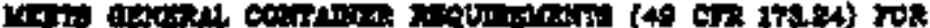

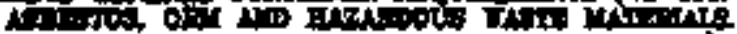

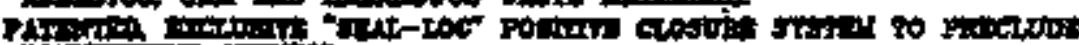

nomitrin arthts

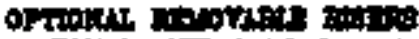

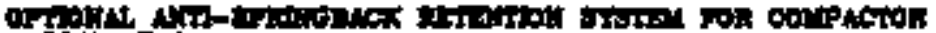

Hutrowit

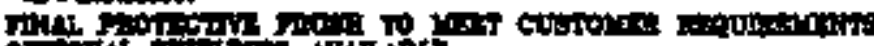

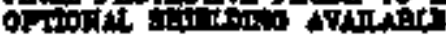
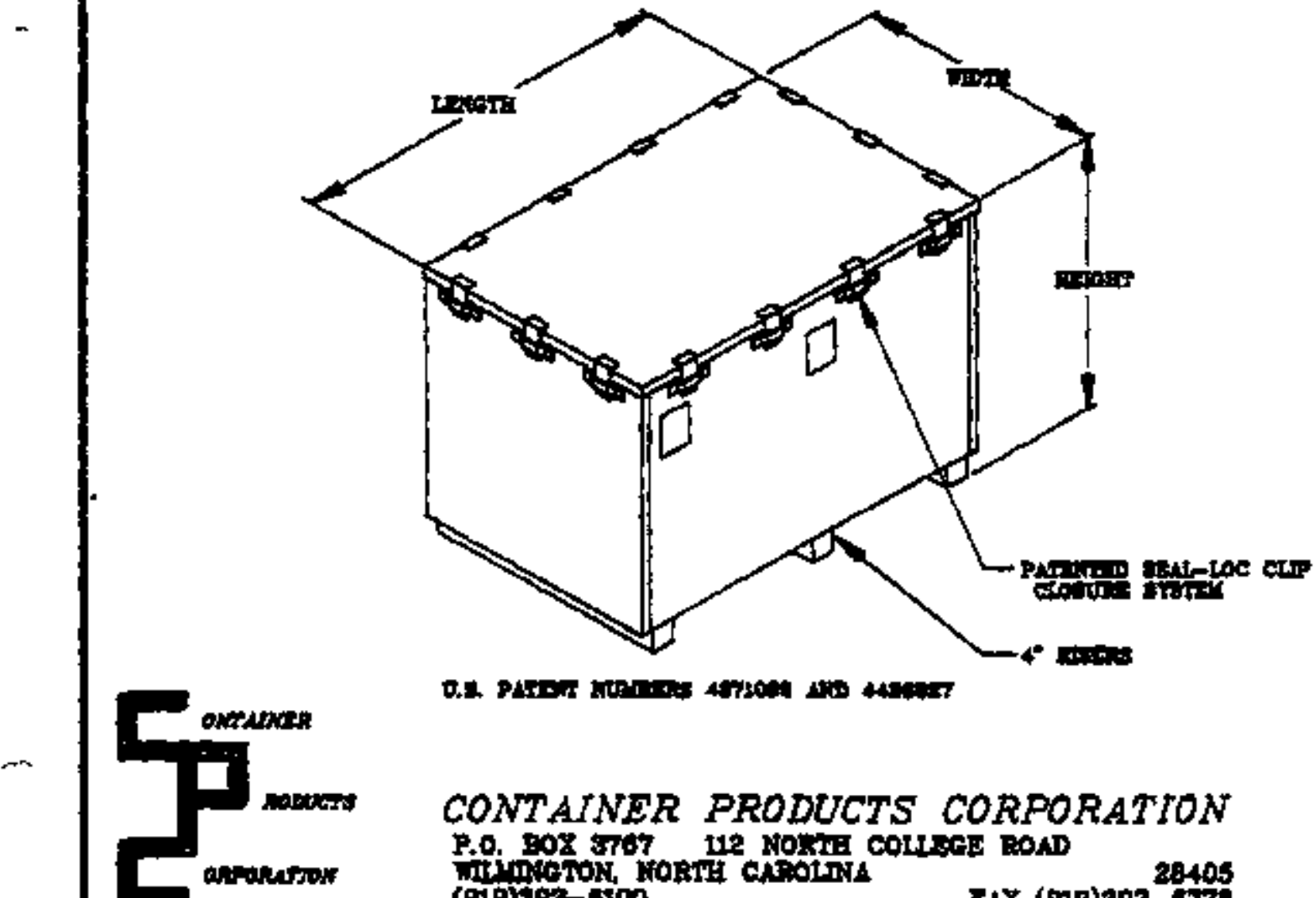

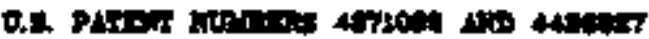

CONTAINER PRODUCTS CORPORATION P.O GOX 3707 T12 NOSTH COLLSEE ROAD

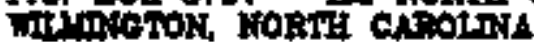
(019) $003-6200$

$F \omega(02) 392-677 b$ 


\section{B-88 LSA WASTE CONTAINER

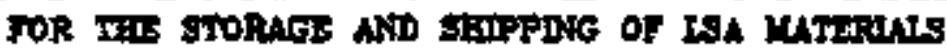

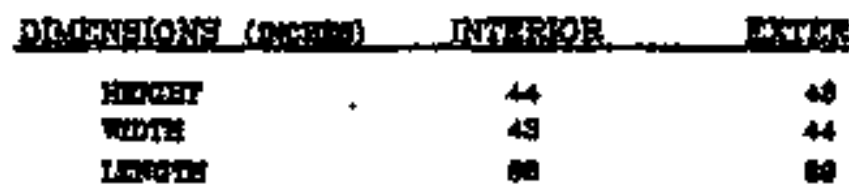

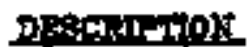

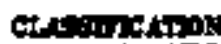

Pupintit Tht

colphert

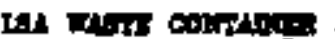

yknits.

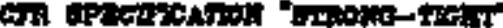

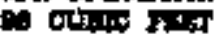

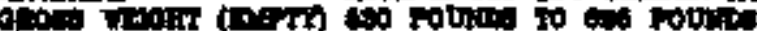

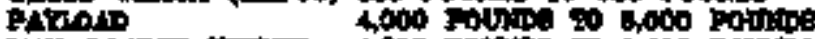

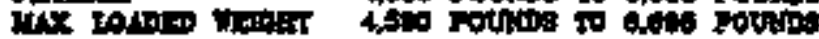

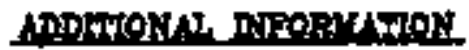

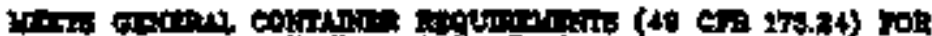

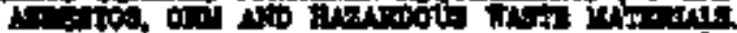

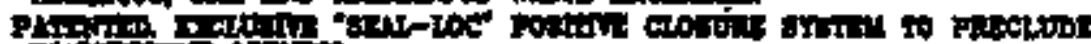

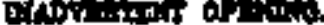

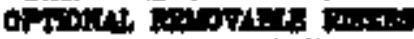

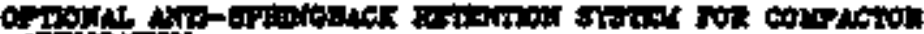

isiteroin

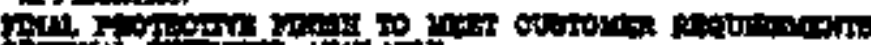

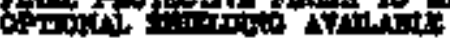
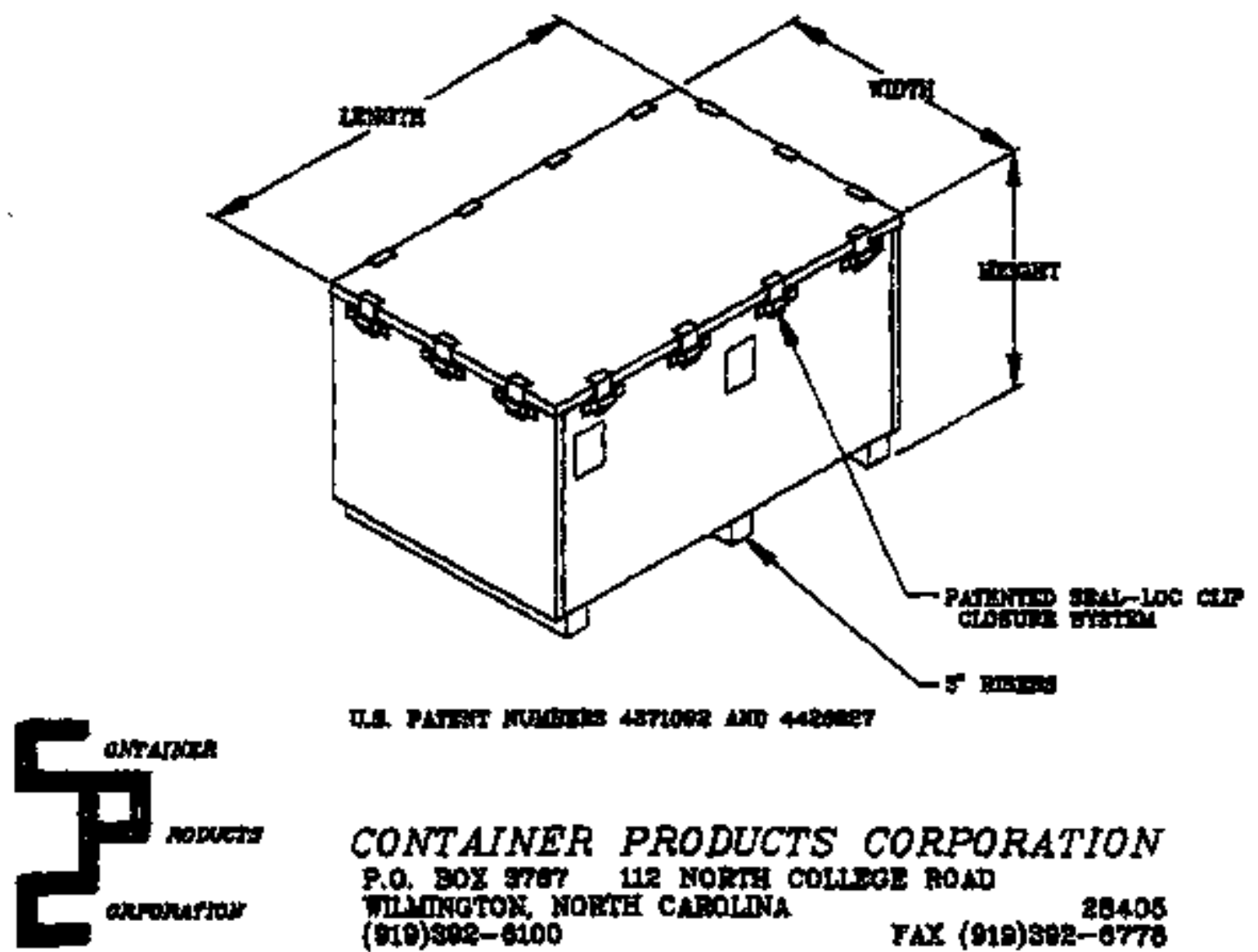

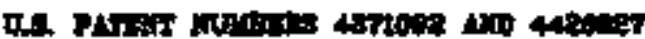

CONTAINER PRODUCTS CORPORATION

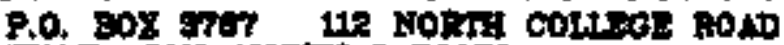

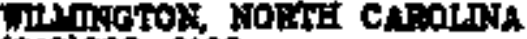
(10) $\mathrm{sen}-8100$

FaX (919) $\sec 2-6 \% \cos$ 
Holly Rea, GATX Stephen Fraser, Enviroleace (312) 621-6493 (201) 292-2456

FOR RELEASE: MMEDIATELY

GATX CAPITAL WASTE BY BAIL, TONNT VENTURE

SAN FRANCISCO, Aprit 11--GATX Capital Corporation has entered into a joint venture with Envirolease, Inc. to provide capital equipment for the intermodal movernent of selected wastes and recyclables. GATX EnviroLease Corporation combines the equipment and financial expertise of GATX Capital with the knowledge and specialization of the waste by rail market of Envirolease, Inc., and Fraser Group, Inc.

GATX Envirolease will provide lease finarcing for a ftll range of intermodal equipment including special purpose containers, chassis, raikcars, and other material axd container handling systems such as tippers, sidehandlers and notary dumping technologies. The equipment will be dedicated to the intermodal transportation of non-hazardous and selected hazardous waste such as municipal solid waste, incinerator and coal ash, sanitary and industrial sludges, contaminated soil, construction and demolition debris, and recyclables.

Potential customers include a wide range of waste companies, railroads, waste transportation compantes, and other generators of waste which are considering in-house remediation of captive sites which would require intermodal containers to transport and dispose of the waste.

$$
\text { -more-- }
$$


Page 2

"We embraced the expertise and reputation of Envirolease and Fraser Group as an entrance into providing financial services for the intermodal movement of waste by rail," said Brooks Laudin, vice president, corporate development, GATX Capital Corporation. "The movement of waste and recyclables is making a shift toward rail due in part to the industry's consolidation of waste streams. Intermodal conkainers are interchangeable berween truck, barge and rail offering waste managers greater flexibility with shipments and cost effective modes of transporting wastes." Intermodal containers eliminate the need for onsite rail loading facilities and the internediate transfer of waste from one mode to another, he added.

"The strength of transporting waste by zail is enhanced by the economies of scale coupled with a more environmentally secure mode of transportation, "commented Stephen Fraser, president, GATX EnviroLease. "As the number of available disposal sites continues to diminish, the average length of haul rises, making special-purpose intermodal equipment more suitable and cost effective."

Based in Convent Station, New Jersey, Envirolease, Inc. has marketed intermodal equipment on short and long term leases to the waste industry. Fraser Group, Inc., has provided consolting expertise and makket development services to some of the nation's leading public waste companies on waste by rail issues. GATX Envirollease is headquartered in Morristown, New Jersey.

GATX Capital Corporation is a diversified, asset-oriented, financial services company which invests for its own account and manages assets for other institutional investors. GATX Capital owns or manages portfolio assets with an original cost of approximately $\$ 8$ bitlion, the largest concentration of which includes air, rail and manufacturing equipment. 
Page 3

GATX Capital is a subsidiary of GATX Corporation, which provides more than $\$ 4$ billion of service-based assets inciuding transportation equjpment, primarily railroad tank cars, bulk liquid terminals, ships, warehouses, commercial aircraft, and other capital assets worldwide. GATX also offers a variety of financial services focusing on owning or managing transportation and distribution assets.

$--30-$

(4-11-94) 


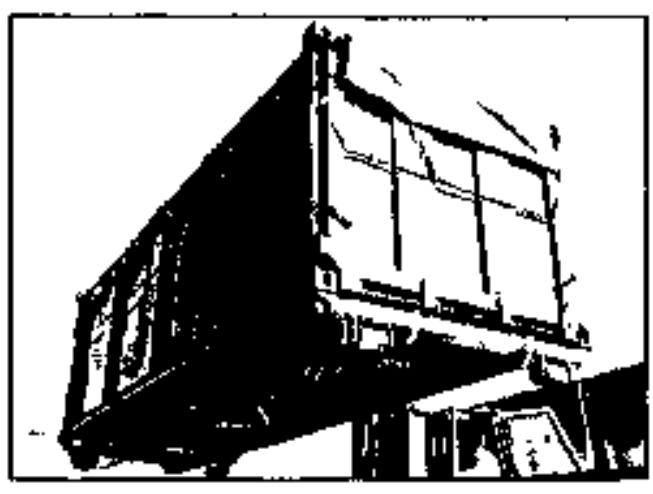

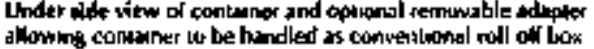

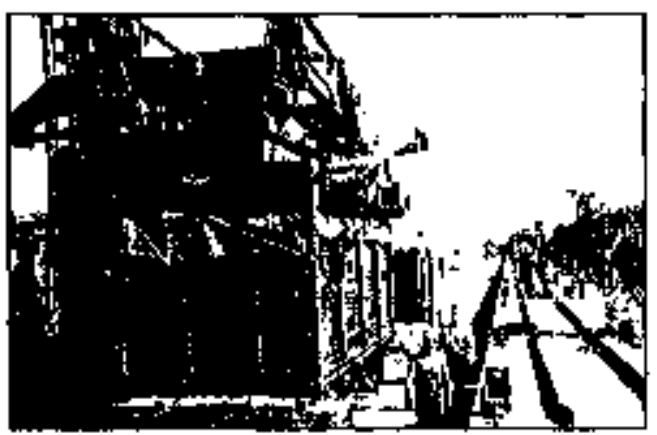

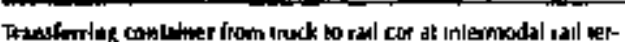

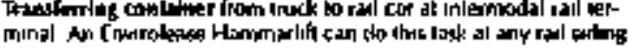

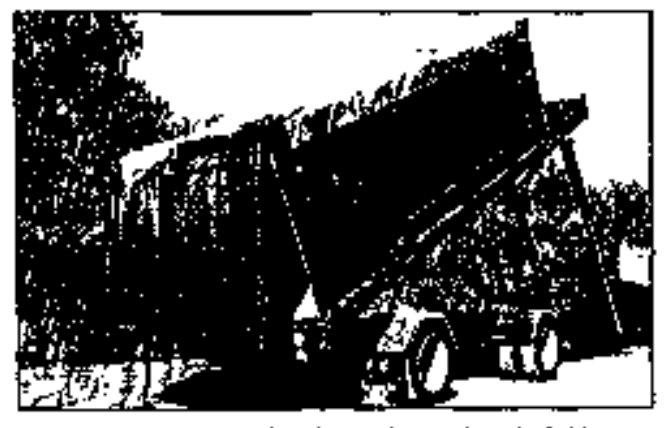

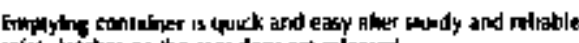
salety bithes on the rear docr ale rekcivad

\section{M $\overline{\text { ORE THAN }}$ JUST CONIAINERS}

Envirolease oflers a range of products and services to support your use of Envirotease containers. .

\section{Products}

- Chassto

Envirolease offers special chassis for use with its containers designed to allow payloads weights exceeding those permissible using ordinary chassis.

\section{- Tip Chasais}

5pecial chassis equipped with hydrautic cylinders allowing containers to be emplied like a dump Iruck.

- Hammarlia

Mubile contamer Nitting device which lưns any rail slding into an InIermodal terminal.

\section{- Roll-Dif Sleds}

Sled like adariter which allows Envirolease containers to be hardled as a rolloff box.

\section{SeRVICES}

- Fleet Management

Enwrolease will manage your conlainer equipment insuriog optimal utilization and maintegrarke.

\section{- Profect Plannimin}

Envirolease can help you determine if conlainers make semse for you or to asslst in the use of containers on specilic projects.

\section{CAIX E'sl:}

GATX Envisolese Corparatuon High Street Court Morristown, NJ 07960 $\mathrm{F}=2 \mathrm{x}: 201 / 292-9160$ $800 / 105-2555$
ReDUCE YOUR WASTE

TRANSPORTATION COSTS NOW

BY LEASING INTERMODAL

Shipping Containers

FROM

\section{ENVIROLEASE}

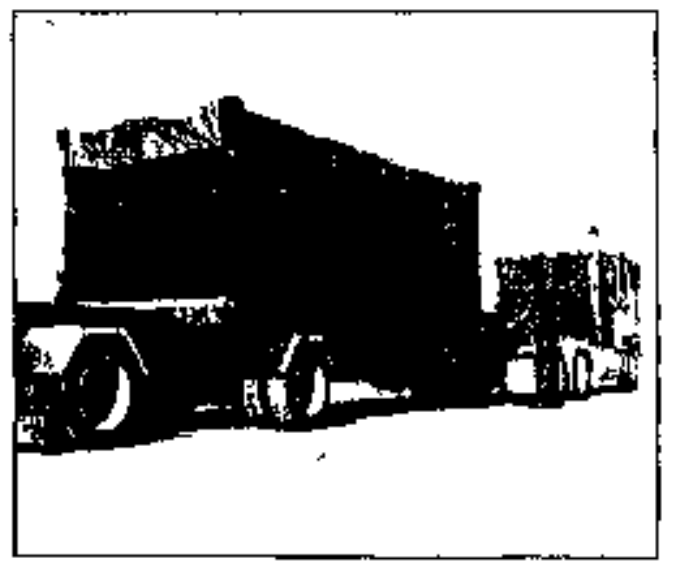

With containers from Envirolease, convert your waste shipments to intermodal movement and take advantage of lower costs and flexibility of containerized transportation. Here is how. 
More and mone waste companics are tectucing Iransportation costs by shipping their wacle by rall vsing specialty designed containers. Unlil now.

thise containers have not been available for lease and could only be obtained lhrough purchase.

Envisofease now offers a complete line of shipping conlainers, supporl equigment and services to enable vour comparry lo enjoy the following benefits of conlainerizing waste shipnienls:

- Waste shipped in Envirolease containers is sealed from the environment in a weather light conlainer which is hydroslatically tested prior to leaving the factory.

- Emvitolease containers can be used regardless of the ayailability of rail track at waste handling or disposal siles.

- Shipments of wasle in Envirolease conlainers move unobtrusively ihrough esiablisthed channels of commerce.

- Transierring containerized shipments for waske from one mode of transportation to arother can be performed at huthdreds of intermodal facilities in Norlh America.

- Shlpping wasle by rail is recognized as being the sales way io ship wour wasle and offers a meatns to reduce or eliminate traffic congestion problems al some facilities.

\section{Phrsical Description}

Envirolease containers are the producl of a four Yęar development and testing proxess. The conlainers afe based on designs currently used by several thousand exisling containers which hawe been handling hazandous and non-haxardous wasle throughout North smorica by rail, Iruck and barge since 1985.
Envirolease containers represenl a rcilncment of thesse earlies designs and tosers of Envirolease containers will enjoy the generatlonal improvements and added flexibility incorporated into Envirolease contziners.

Faturicaled of heavy gauge steel, the comtainers have been designed and tested to meet impact and durability requiremeints of rạil and truck camplers. The comlatiners are buill to nom lnal inemalional Slandard Organization (ISO) specificalions insuring universal compatibility with conlainer handling equipment throughout the world.

The conteiners incorporate an open top to facililate loading. This opening is sealed prior to transil by means of a tarpaulin top and elastic cords. An optional lighl-weight, durable hard top is also anailable.

Emplying the container is identical to thal of a dump tuck by means of a single piece top-hinged door at the rear of the container. This door is equipped with compression gaskets, reliable locking mechanisms and ratchels which are designed to achiegve a water light seal allowing the container to handile mojsl cargo.

\section{TeChnical Specificamons}

Unils are capable of two bigh slacking when loaded and it wilhin 20 boot $\$ 5 O$ envelope.

Conjainers comply whth applicable requiremenls of the Assoriation of American Raifioats (AAR) M-930-90 performante standards and will be lesed and certilied as required.

Containers are tested and certífied by Amerlcan Bureau of Shipping (ABS).

(1)

HWGES $=$ SINCLEF PHE

\section{External Dimentions}

Comainer Lenglh

Conlaines Wikth

Conlainer Helght

19

B

\section{Apertures}

Door Width

Doot Heighl

Top Opening Lenglh

Top Opening Width

Volumes

Weights

Los

Maximum Gross Weight Tare Welght

Payload heigly

52,910

5,500

KC

23,996

12,128

21,501

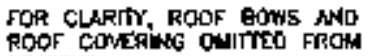

(2)

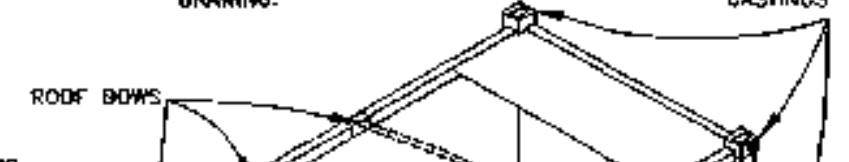

TOP OPEMIIOC

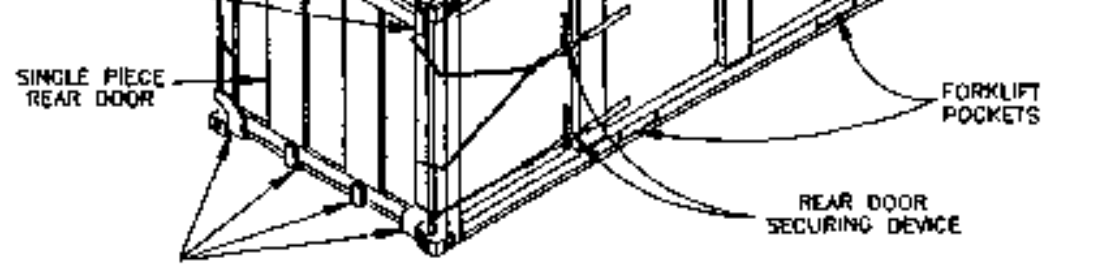

REAR DNOR SAFETY LATCHES 


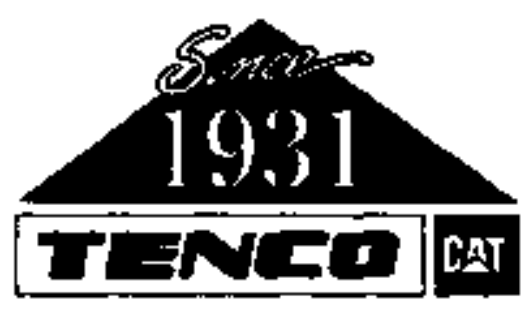

May 10,1994

Quote 730-194

Mr. Frank Groffie

Horrison Knudsen Corp.

180 Howard st.

San Francisco, CA 94102

Tenco Material Handling Diviston is pleased to submit the following proposal for your consideration:

1 Model: VBooD Cat New Lift Truck

Caterpillar 320BT Diesel Engine

Planetary Drive Axle with oil Disc Brakes

oscillating Steer Axle

3-Section valve

Five degree forward, 10 degree back High Mount iflt Cylfnders

Counterwelght

Cab consisting of:

-Full suspension seat

-Tilt gteering colum

-Front, rear and top windsinield wipers

-Front and rear windshield washers

-BodB(a) sound level at operator's ear

-pressurized filtered ventilation system

-heater

-rear view mirror

-Tail and stop lights

-two slde view ilghts

-audible back up alarin

-power steering

Tires: $18.00 \times 33$ dual drive tires (E-4)

$18.00 \times 25$ steer tires $(E-4)$

Mast: Maximum fork helght: $301 "$

Overall lowered helght: 259.0"

Twist lock helght: $3 \mathrm{Bs}^{\prime \prime}$ ( 3 high stack)

Gooseneck mounted container handler

Includes container handler carriage with $20^{\circ}-40^{\prime}$ expansion Capacity for 3 high: 61,000 lbs.

working light package: 4 flood lights front \& rear

Afr conditioned cab

site asgembly

Price: F.o.B. delivered

$\$ 275,547.00$

plus tax 
Page 2

Options:

4 high stacking, twist lock helght $483^{\prime \prime}$, Capacity: 53,400 lbs.

V900CH with container handler

$\$ 283,421.00$

plus tax

Good neck mounted, 3 high

Capacity: 75,700 lbs.

On site asemily included

Price: F.o.B. factory

$\$ 282,258,00$

4 high stacking

plus tax

Capacity: 67,400 1bs.

On site assembly included

Price: F.o.B. factory

$\$ 289,553.00$

plus tax

Delivery: August, 1994

Warranty: Cat 12 month parts and labor, unlimited hour usage, Cat "Parts Fast, Parts Frea" pollcy

Accepted by:

Morzison Rnudsen

Date
Proposed by:

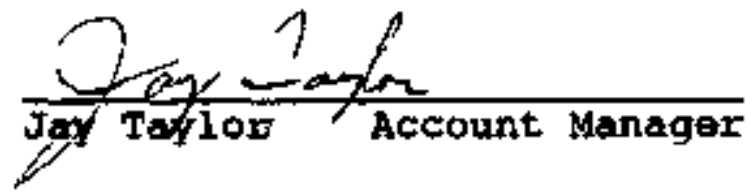




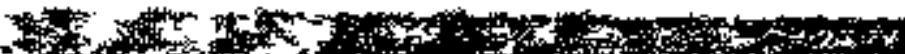

to

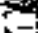

促

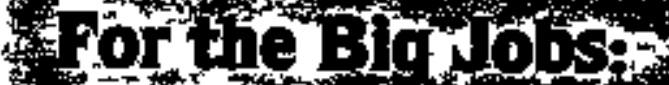

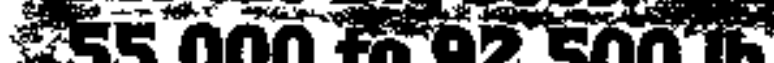

敉:

che

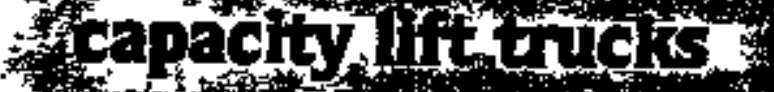

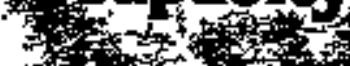

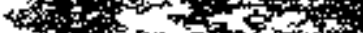

值

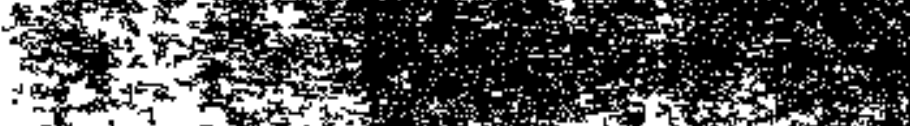

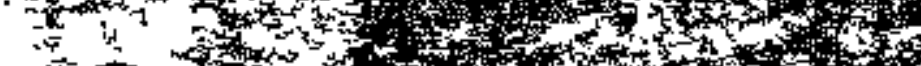
$\mathrm{H} / \mathrm{f} / \mathrm{d} / \mathrm{f} / \mathrm{f} / \mathrm{L}$.

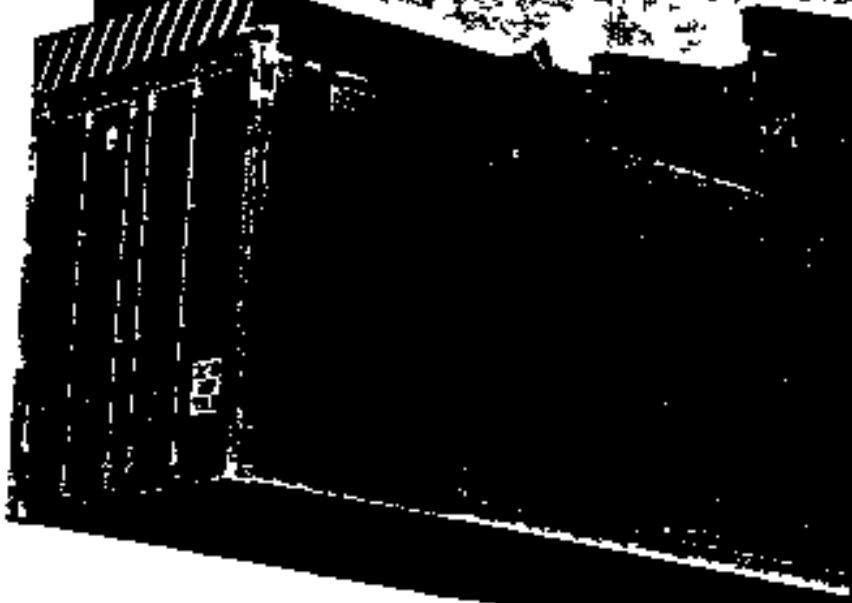
$\therefore \therefore$

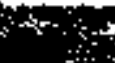

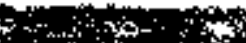

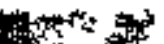
intions

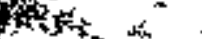

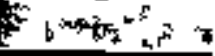

\section{:}
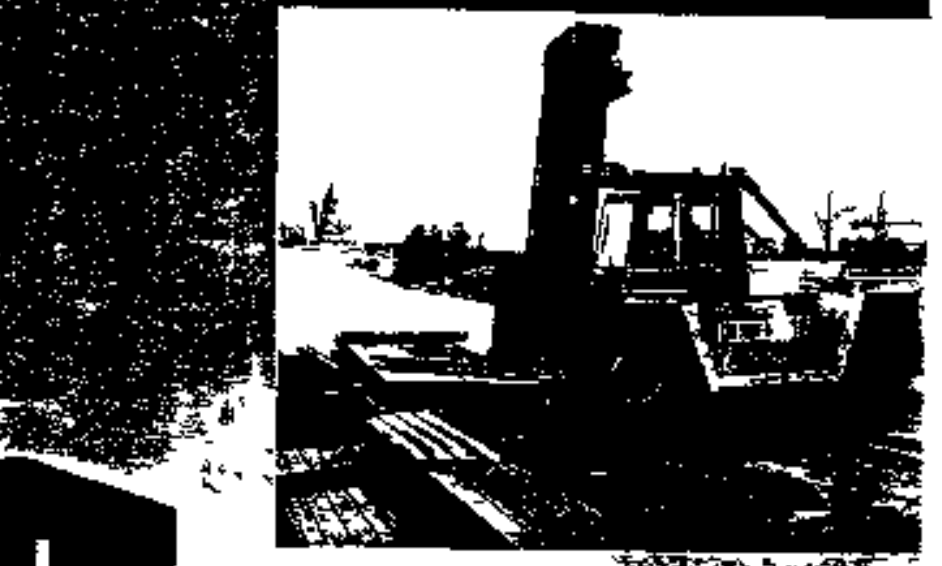

कonets

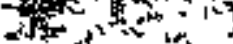

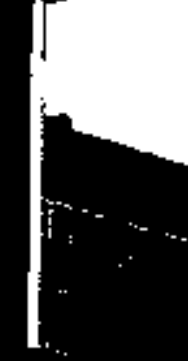

it
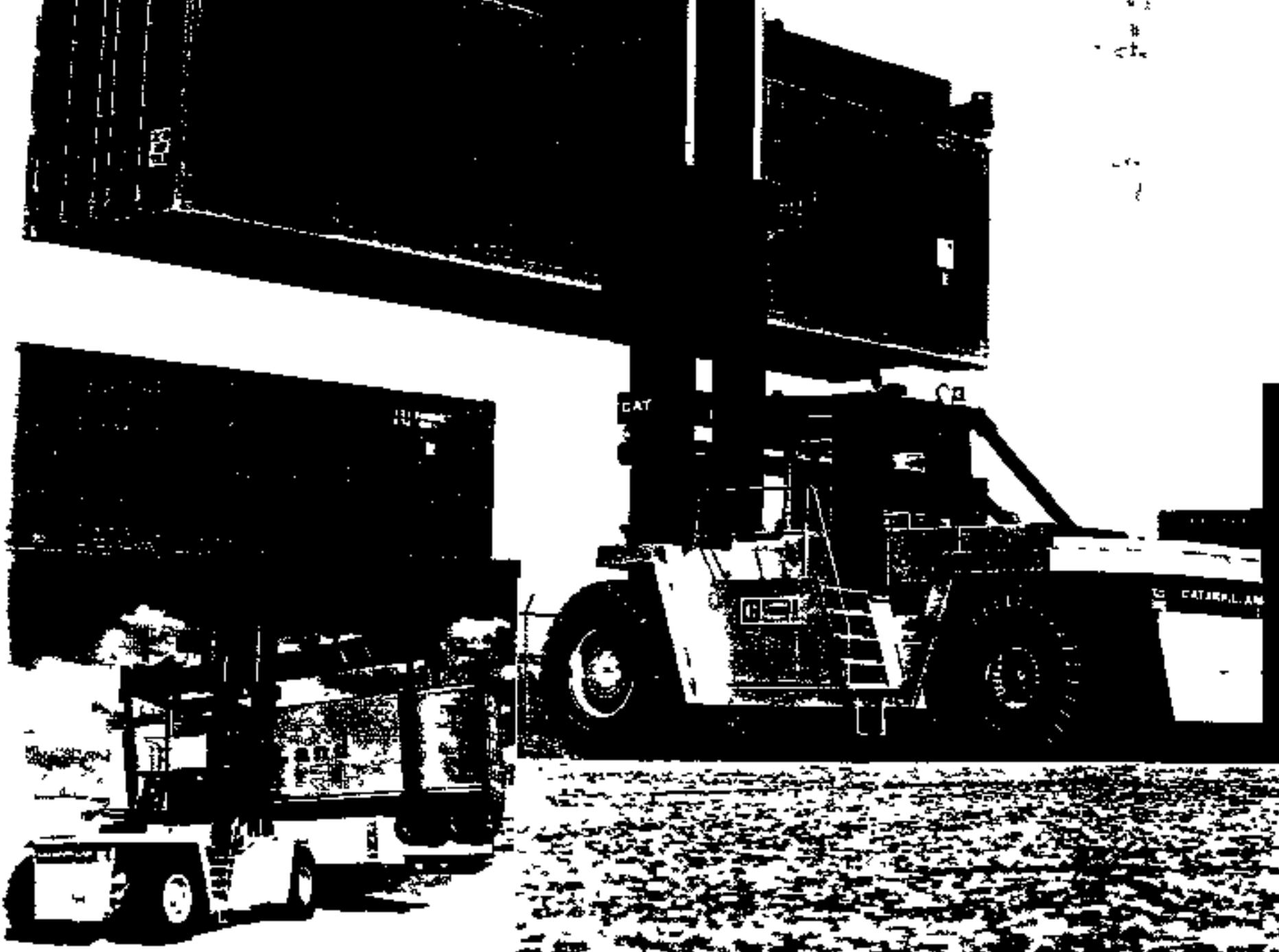

1 3 (1)

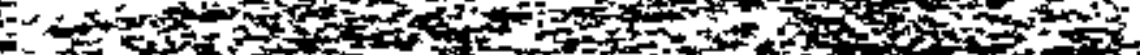

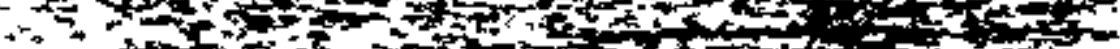

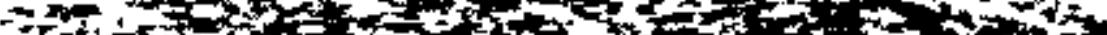

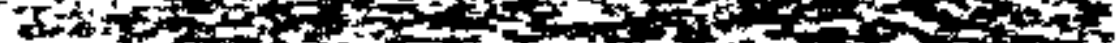

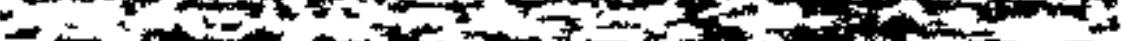

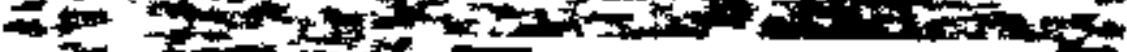

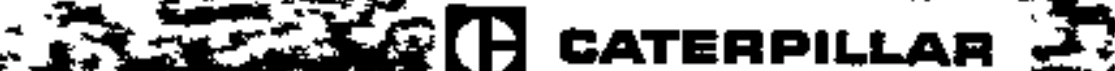

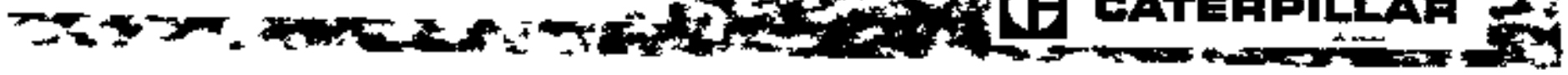




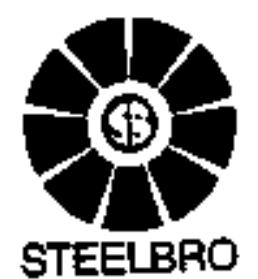

\section{MK6 STEELBRO SIDELIFTER}
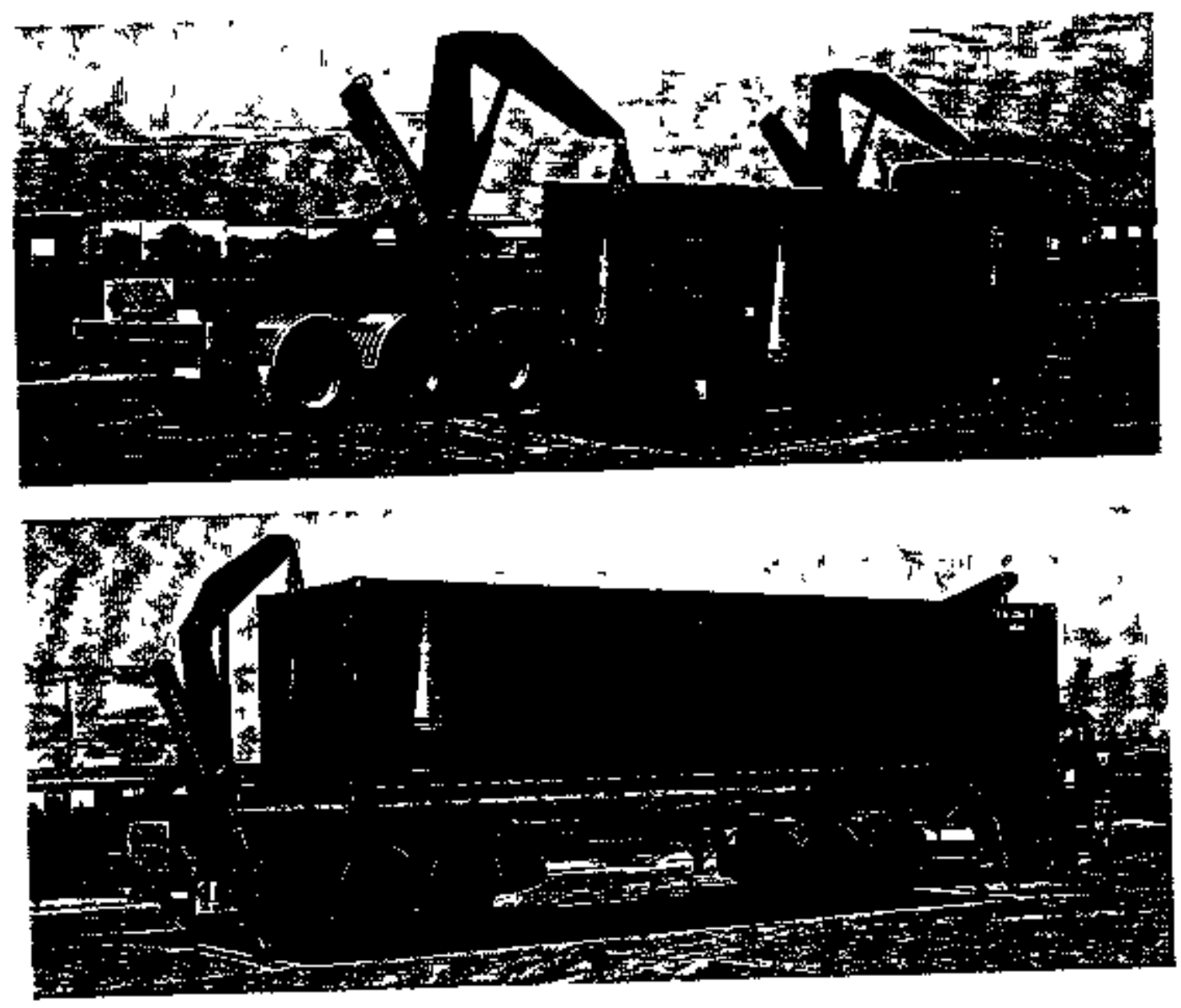

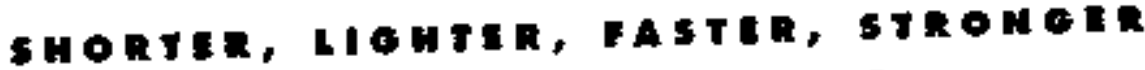 Anomerevactile}

Shelbro Sidelsters oxe highty efficient all-iv-one conlainer handing and delivery systems They parmit raped loading and unboding on virkualy any hat, reosonably hard surfoce, allow doubte siacking of hilly loaded conbiners, permit shiffing and de-stuting ot ground level and maks the transter of containers to another vani-troilor a simple and safe operotion

The new MK6 Stestbro

Sidelifier hos an overall lengh of $136 \mathrm{~m}$ (inctuding the fornt arcl and eosily complies with $1372 \mathrm{~m}(45 \mathrm{ft})$ roiler lengith regulations this means thot 40 $\mathrm{ft}$ and $20 \mathrm{f}$ conkamers con not only be looded and unlooded with safery and sose, but can be eorried in many countries without touvel restrictions being imposed due to the overall length of the traiker. There are c number of other Fentures of the new MKO Sidalf that bring consideroble bentfils to the transpoxt industry 
With o kare weight from 11 tonnes, the new design is considerchbly lighter. Also. operation has been mode faster through dual speed and variable speed controls. $\checkmark$ is soler as there is grecter conlrol over the movement of the contoiner and it is shonger as the fift copocaily is roted bo 30 lonnes and rested to 37.5 tonnes. Finclly the MK6 is more versotile as its oxtended working rodius enables componion vehides to crive post during conkiner trensfers.

\section{more Niw pritruts:}

- Greater emphasis on sofoty

- Rapid depiloyment of stubilizer legs for taster turnarounds

- Éaty to use controds

- Veriable speed remole controls bor superior harwiling flexibiliby of the container

- Gractier thf copoxity, partiaslorly at hull outreach

- High speed operction, with dual speed and wriests speod controls

- Significently reduced laro weight, now from 11 connes

a Graler stabitty

- New stylo of twistods and tiffing huss for raducact mecinteranse

a length reduced to $13.6 \mathrm{~m}$, including fromt torc, to swit regulations.

- Superior monosenurability Inow a comentional Aming circtel and greater conitrol over monement of the container.

- Raled capocily of sm

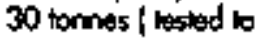
37.5 tonnes]

- Reducad shoxk loodings, in the trydraulic system resulting in lower shesses and strains

E Higher copocily motor.

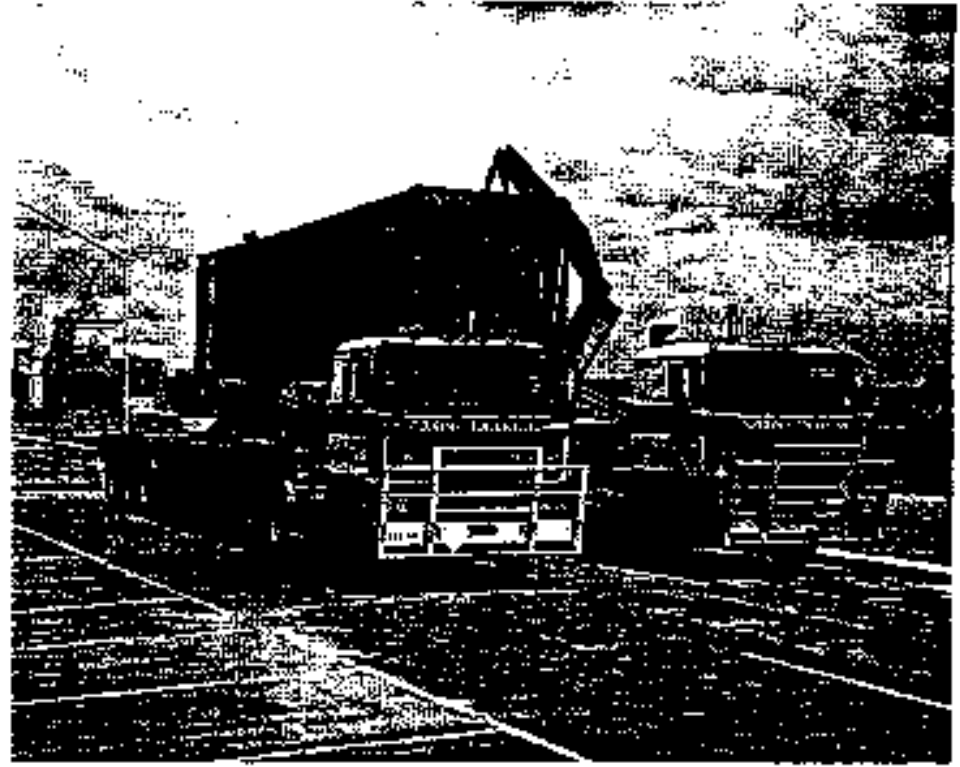

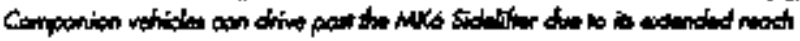

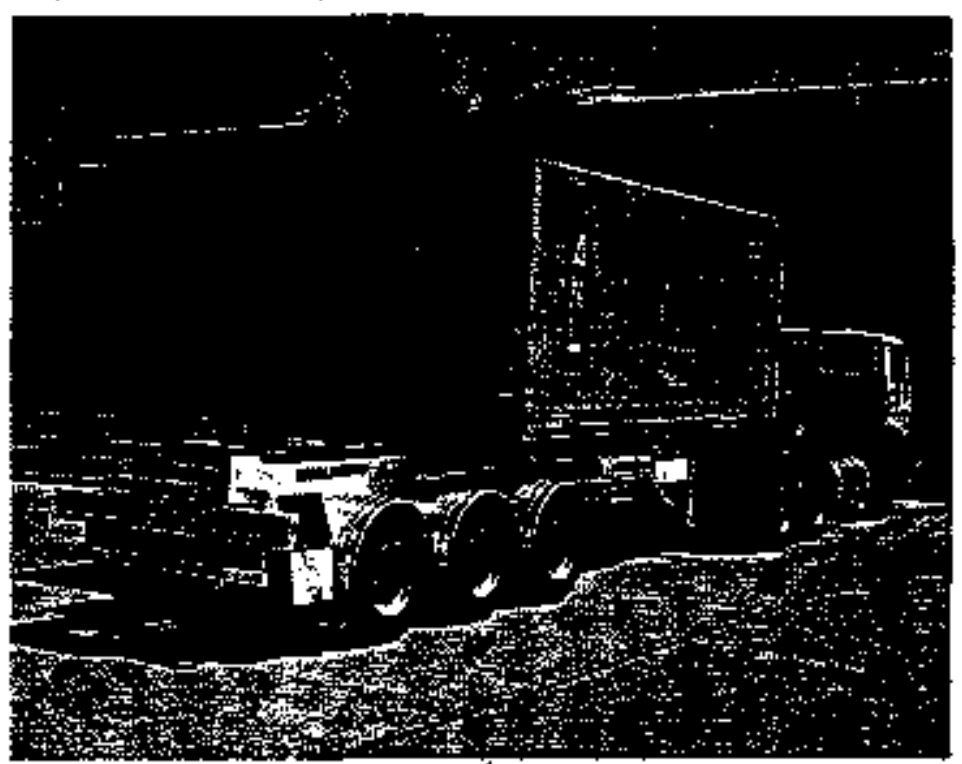

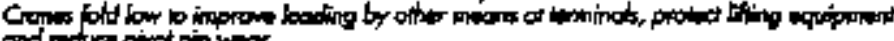
and netwes pinct pin waor

Distributiod br
Stad Bros (NV) ld

P.O. Bon 11077,

Sodtum, Christhurch, Nion Zeoland

Tetephent:

$N T+\$ 4+3+349 \$ 499$

Facimiler

INT $+64+3+3.485786$

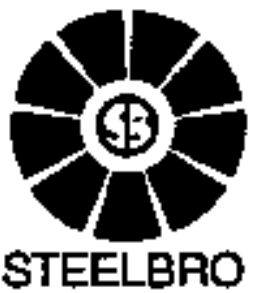




\section{Appendlx C}

\section{Backup Data for TRU Shipments}

Appendlx C-1: TRUPACT-II Product Literature Appendix C-2: NuPac 125-B Reference Article-TMI Shipments 


\section{Appendix C-1}

TRUPACT-II Product Literahure 
TRANSPORTATION OF CONTACT HANDLED TRU WASTES

R. T. Haelsig

Pacific Nuclear Systems

Federal Way, Washington 98003

G. J. Quinn, R, A. Jothno⿰

Nuclear Packaging, Inc.

Federai way, Washington 98003

K. L. Ferguson

Hestinghouse, WIPP

Carisbad. New Mexico 88221

\section{ABSTRACT}

Contact-handled transuranic (CH-TRE) wastes will be transported by a new design package for shipment from DOE sites to the Waste Isolation Pilot Plant (WIPP). The new package is called TRUPACT I1. CH-TRU wastes are those contaminoted with alphaemitting transuranful radionuclides with half-lives greater than 20 years and concentrations greater than $3.7 \mathrm{kBg}$ ( $100 \mathrm{nCl}$ ). The wastes are storedat DOE sites in drums and boxes and w1 1 be loaded into TRUPACT II using handsoon techniques since the dose rates are low. The TRUPACT II design wi 1 cantain 14 drums of waste. The package provides double containuent which allows transport of greater than 740 GBq (20 curles) of plutoniun. Each contalnment vessel is unvented during transport and has seals which arenleak-tight" during both hormal and accident conditions of transport. tonloding of the druns from each TRUPACT II is also a hands-on process.

\section{TNTRODUCTION}

Commencing in October 1988. nuciear waste relazed to defense facilfties operations at varlous iocations (Fig. L) wit? be delivered to the Department of Energy's Waste Isolation Pilot Plant (WIPP) near Carlsbad. New Mexico. The factlity is belng destgned to store as much as 25 years worth of these shipments.

More than 15,000 shipments are anticipated. Consistent with that need, Hestinghouse Electrie is lnvolved with the pianing, i ap iementation and management of waste containers development to safely transport that waste. The major constltuent will be transurantc, a pha-emitting nateriai ("contact wasten). Activitles are under way to address boxed and drummed waste. 
FIGURE 1

\section{TRU DEFENSE WASTE GENERATING AND STORAGE SITES}

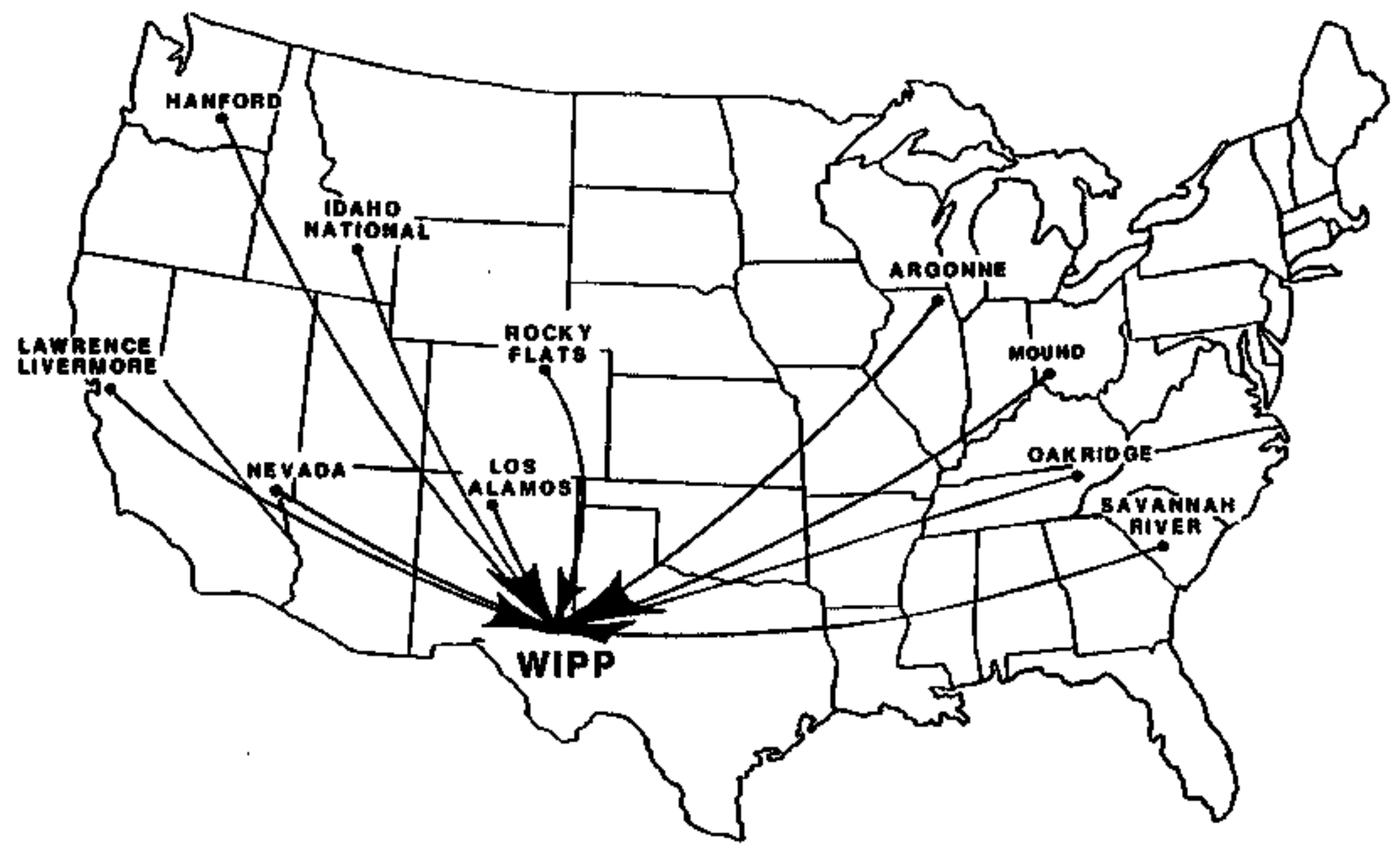


The constituent waste consists of a variety of forms emanating from iaboratory wastes and by-products from production operations and reclamation processes used to recover plutonium from contaminated equipment and materfais. Exemples include laboratary clothing, gloves, tissues, polyethylene bags, glass, tools. and cemented siudge. Oyer $170 \mathrm{Ml}$ (6 filion cubfc feet) of waste is anticlpated to be shipped. Nore than one shipment is expected to be delivered each day to the MIPP site.

The transportation of these tronsuranic wastes will utilize the results of prograns to evolve (a) contalner design (Type B) to transport druas, (b) design of a Type B container to handle boxed waste existent at sites, (c) a Type A waste box design to accommodate newly generated waste and compatible with emplacement in a Fype B contafner.

This paper addresses the TRUPACT II (Type B) conteiner wheh w1 transport drums and iternatively the Type $A$ box beting planed. The design, certification and fabrication of TRUPACT II is being performed by Nuclear Packaging under subcontract to Hestinghouse.

\section{CH-TRU WASTE}

The CH-TRU wastes which will be transported in TRUPACT I I are contaminated with greater than $3.7 \mathrm{kBq}(100 \mathrm{nCl})$ of alphaom1t 1 ing TRt nuclides with a half-iffe greater than 20 years per gram of waste. The dose rate on the surface of the drum or box contafing the waste must be less than $2 \mathrm{mSv}$ (200 mRem) per hour to be classified as contact handed for acceptance at the HIPP. wastes excesding $2 \mathrm{mSV}(200 \mathrm{mReal}$ per hour are classffied as remote-handled TRU or RH-TRU wastes.

The DOE TRU aste generator sites have been storing TRU westes retrlevably since 1970. Over the next 25 years DoE pians to transport the retrievably stored and newly generated waste to the WIPP. Of the ten waste genarator sites, the Idaho National Engineering Laboratory (INEL) has the majority of the retrievabiy stored wastes with approxtmately 60 percent. Hanford, Los Alamos National Laboratory (LANL), Savannah River Plant (SRP) and Oak Rioge National Laboratory also store TRU wastes retrievabiy. The new 1 y generated waste is produced principal1y at the Rocky Flats Plant fol 1 owed by SRP, Hanford, LANL and Lamrence Livermore National Laboratory.

An Important part of the plan for receipt of TRU waste at the WIPP has been the development of a process by which TRU wastes can be characterized and shown to met the waste acceptance criteria at the UIPP. The characterlation process has become a signiflcant effort for sites storing or generating TRU waste since it establishes that the waste in the containers weats the al owable 1 inits. 
The parameters of the waste important for receipt of waste at the WIPP are also jseful for obtaining the information needed to evaluate the safety of the waste durfing transport. The parameters of interest fnclude the identity and quantity of the radioactive material inel uding fissile content, chemical and physfcal form, potential for generation of gases, thermal power and weight.

To date, many CH-TRU wate streams generated at the DOE sites have been described in a wate acceptance certification plan. The plan has been reviewed by ifP and the waste streams have been approved for recelpt at WIPP. One of the benefits of this aporoval process is the framework it provides for categorization and certification of CH-TRU wastes for transport in TRUPACT II. The broad categortes of CH-TRU wastes identffied for transport in TRUPACT II include organic and inorganic materials inether solid or solidified form. Thesewastes have been and are being generated from research and development programs or defense programs. A wide vartety of items are in the waste. TRU contaninated paper-wipes, clean-up rags, laboratory clothes, absorbed iquids, solidified organic solutions and plastics make up some of the organic wastes. Metal and gias iteas, such as discarded tools, pumps, valves, racks and laboratory glassware are in the inorgantc waste category.

The CH-TRU wastes are contained in either drums or boxes which reet the Type A packaging requirements. These containers a 1 so have gas reiease provisions, such as vents, filters or senipermeabie gaskets since pressurized containers are prohibited at the IPIP.

\section{TRANSPORTATION PACKAGE}

TRUPACT II is a sealed transportation package for CH-TRU waste which inciudes two separate contajnant vessels in striet accordance w1th NRC requirements (10 CFR 71.63 ) for two levels of testable containant when transporting Pu in excess of $740 \mathrm{GBq}$ (20 curtes) per package. A TRUPACT II $1 \mathrm{~s}$ sized to contain fourteen 200-L (55-galion) druns of CH-TRU wase and al aw three packages per trailer during transport for a total of 42 drums of waste per shipnent. The ability to transport boxes 15 also part of the TRUPACT II design.

The outer level of contaimment in TRUPACT II fs provjoed by an outer containment assembly (OCA) which consists of an exterior staintess steel skin, a reiatively thick layer of polyurethane toafl and a stafiness steel pressure vessel instide the foas. The exterior of the OCA fs in the form of a right circular cylinder wth an external diameter of $239 \mathrm{~cm}(94$ inches) and an externat helght of $300 \mathrm{~cm}$ (118 inches). The exterlor stainless steel skin provides a tough, puncture-resistant surface which absorbs energy durting the hypothetica) drop accident conditions. The skin is backed everyuhere by the closed-cel1 poiyurethane foam that is approximately $25.4 \mathrm{~cm}$. (10 inches) thick. The foam is an excellent tepact-energy absorber and thermal insulator. Its presence 
protects the OCA's inner pressure vessel from the various regulatory drop conditions and a 150 retards heat input durfing the hypothetical fire accident condition. The foam is flamentesistant and self-extingulshing thus minor tearing of the

OCA exterior skin is fully acceptable. The pressure yessel inside the foam is called the outer contajnant vessel (OCV) and is designed to withstand $345 \mathrm{kPa}(50 \mathrm{psig})$ of internal pressure. The ocV consists of a cylindrical sheil, two dished heads and a set of closure rings which jotn together to form a double o-ring bore seal. The seal is designed to a "Teak-tight" leakage rate of $10^{-7}$ scc/sec in accordance with ANSI N14,5. This low leakage rate applites to both the norsal and hypothetfcal accident conditions of transport.

Nested concentrically inside of the OCV is the separate inner cantalnment vessel (ICV) which is a completely removable presstire vessel made of stalnjess steel. Like the oCv, the ICY a 1 so consists of a cylindrtcal she11, two dished heads and a set of closure rings with bore seals. Similarly, the leakage rate for the sea] is "leak-tight" per ANSI N14.5. The internaj cartty provided by the ICV has nergy absorbing honeycomb in the upper and lower heads to protect the heads from impacts from the contents during drop accident conditions. These large cell al uminum honeycomb spacers also serve as generous plenums for gases generated by the contents. The ICy design also incorporates beds of catalyst recombiner material to $1 i$ at the formation of combustible gas mixtures during transport. The 14 drums placed within the ICV are supported on a single paliet which permits loading and unioding of alt drums in one 1 ift.

Both the OCV and ICY are equipped with vent and seal 1 eak test ports on their respective closure rings. These permit venting or inerting of the vessel cavities and perforance of leakage rate tegts on the oring seals.

Another foture of TRUPACT II is the use of fork-ift pockets at the botton to permit routine handiling by means of fork-]ift trucks. The pockets provide for access by the forkijft truck from either side when a TRUPACT II is on a trailer.

Tie-down of the TRUPACT I I packages to the trailer is by aeans of four attackmeat points per package. The attachments are located at the bottom outside surface of package and are sized in accordance with. the draft standard for tie-down, ANSI NL4.2 and the requirements of 10 CFR $71.45(b)$.

The trailer for TRUPACT II transport is of lightwelght construction featuring a single drop gooseneck. The dimensions of the trafler were selected for compatfbility with state and federal highway regulatfons. The trailer and three loaded TRUPACT II packages are designed to welgh iess than $28,182 \mathrm{~kg}$ (62,000 1bs.) permitting up to an $8,182 \mathrm{~kg}(18,000$ lb.) tractor while remainting be ow an $36,364 \mathrm{~kg}(80,000$ 1b.) gross vehicle weight. 
TRUPACT II is being developed with the aid of an extensive test program to demonstrate compliance with 10 CFR 71 . Bench scaje tests have been used to 1 i size the exteriorskinthickness and foam density for puncture resistance, 2) prove the sealing effectfveness of bore seals in deformed geosetries. 3) identify acceptable bore seal gap tolerance for leak-tight performance, 4) measure o-ring squeeze forces, and, 5) demonstrate the flame retardant and self-extingulshing properties of the energy absorbing foam.

In addition to the bench scale tests, a one-half scale model of the package's energy absorbing components were tested in $9-m$ (30-foot) drop and $1-m(40-i n c h)$ puncture tests to confirm the selection of exterior skin thickness and foam density.

Two series of fuit scale tests are pianned. The first serjes is with an engineering prototype that will be used to l) confirm the impact and punch performance features. 2) prove the effectiveness of the bore seals after drop and puncture test. impacts, 3) demonstrate the ability of the ICV to survive payload impacts, and, 4) select the "worst" orfentations for the subsequent full-scale tests.

The secand series of full-scale tests is the Certification Demonstration Test Program which wili be conducted by Sandia National Labordtories (SNL). The tests at SNL will consist of one or more 9-m (30-foot) drops followed by one or more $1-$ th $140-$ Inch) drops onto a $15.24-\mathrm{cm}$ (6-inch) ouncture bar followed by a one-haif hour pool fire. Before and after the test series the leakage rate 11 l be tested for the seals forboth the ocv and ICV.

De?ivery of the first triter's worth of TRUPACT II package is currentiy scheduled for 0ctober 1988. This schedute requires continued successes in the testing program, a coordinated effort on the description and analyses of the paylods and dedicated support to the preparations for handing the TRUPACT I I package when lt becomes available for transport of CH-TRU wastes. 


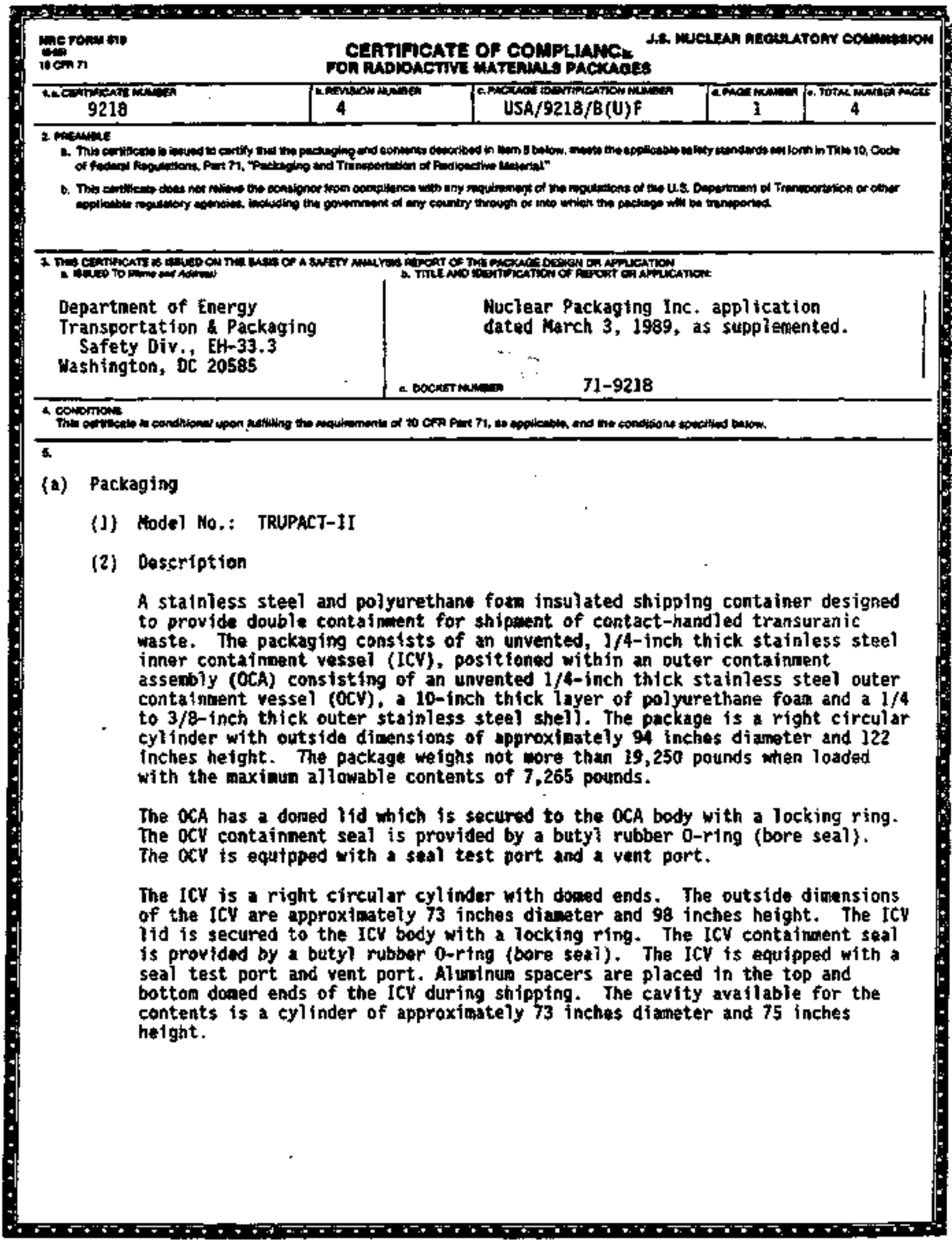


cowomions joontinendy

Page 2 - Certificate Ho. 9218 - Reviston No. 4- Docket No. 71-921日

5. (a) Packaging (continted)

(3) Drawings

The packaging is constructed in accordance with Muclear Packaging Inc. Drawing Ho. 2077-500 5NP, Sheets 1 through 11, Rev. K.

The contents are positioned within the packaging in accordance with Hucloar Packaging Inc. Orawing Hos. 2077-007 54P, Rev. C, and 2077-008 SNP, Sheets I and 2, Rev. C.

(b) Contents

(1) Type and form of material

Dewatered, solid or solidified transuranic wastes. Wastes must be packaged in 55-gallon druns, standard waste boxes (SVB), or bins. Wastes wist be restricted to prohibit explosives, corrosives, nonradfoactive phrophorics and pressurized containers. Within a drun, bin or SWB, radioactive pyrophorics must not exceed l porcent by weight and free 1 feutds unst not exceed 1 percent by voluoe. Flanable organics are Itinited to 500 ppe ta the headspace of any drum, bin or SWB.

(2) Haximum quantity of mterial per package

Contents not to exceed 7,265 pounds fincluding shoring and secondary containers, with no wore than 1000 pounds per $55-g a t i o n$ drun and 4,000 pounds per SWB.

Maximus number of contziners per package and wuthorized packaging configurations are as follows:

(i) - 14 55-galion druas,

(ii) 2 SWBs,

(iti) 2 SNBs, each SWB contafining one bin,

(iv) 2 SWBs, each SuB containing 4 55-gailon druns,

(v) 1 ten-drum overpack (TDOP), containing 10 55-gatlon druns,

(vi) 1 TDOP, contafning I sill,

(vii) 1 TDOP, contalning 1 bin within an SWB, or

(viii) 1 TDOP, containing 4 55-galion druns within an SWE.

Fi55ile material not to exceed 325 grans Pu-239 equivalent with no more than 200 grans Pu-239 equivalent per 55-galion drun or 325 grans Pu-239 equivalent per 5MB. Pu-239 equivalent must be determined in accordance with Appendix 1.3.7 of the application.

Decay heat not to exceed the values given in Tabies 6.1 through 6.3 "TRUPACT-II Content Codes", (TRUCON), DOE/NIPP 89-004, Rev, 6 . 


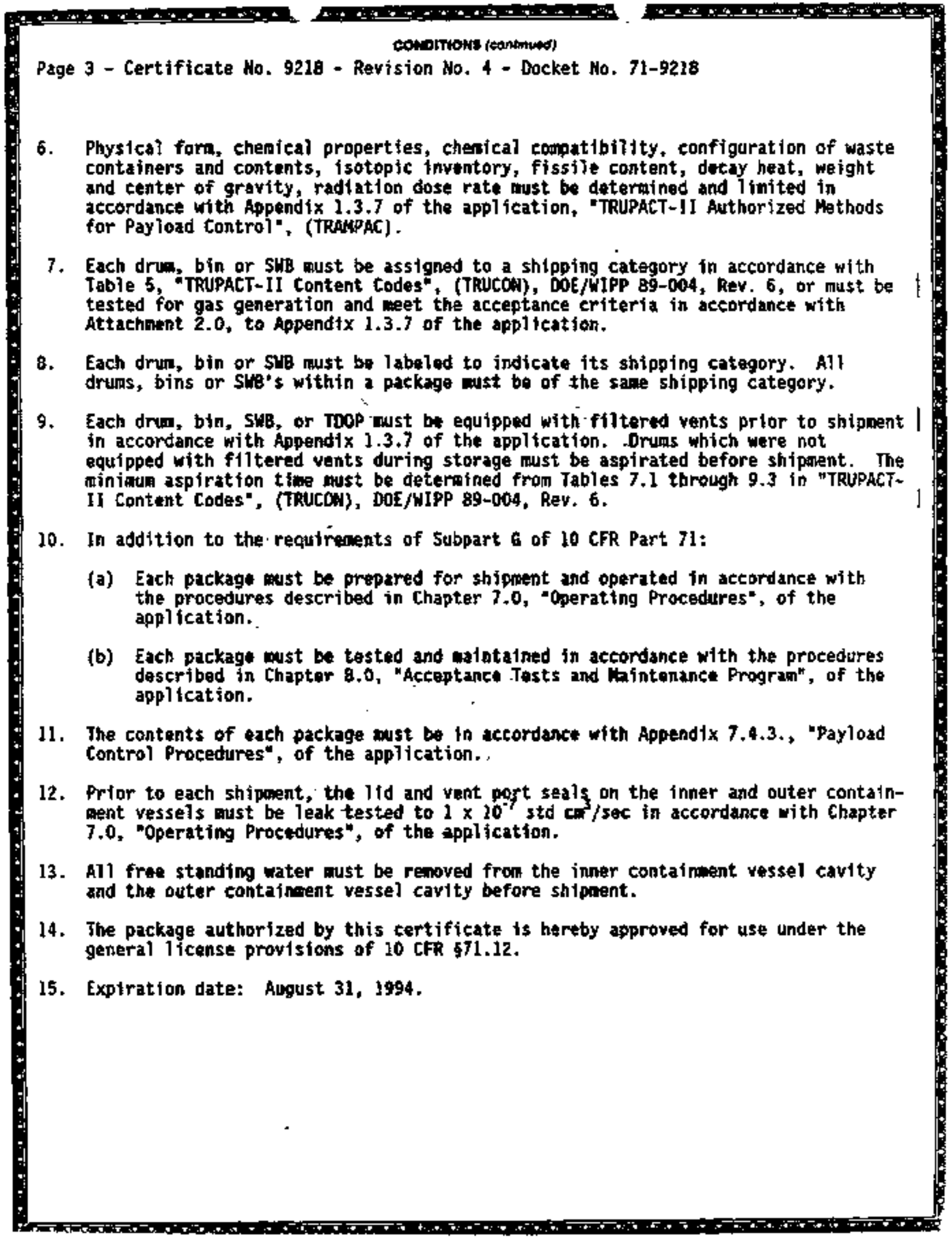




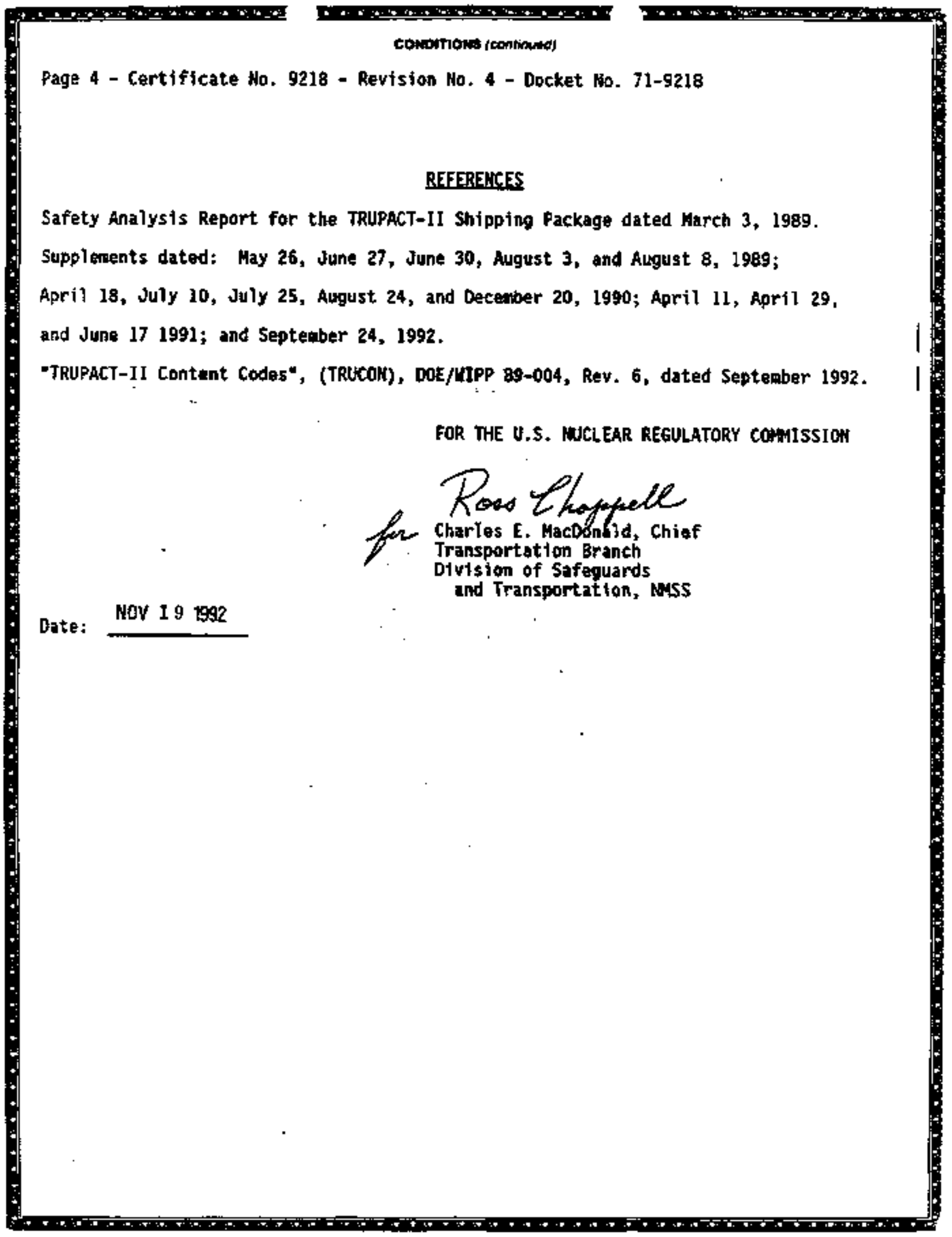




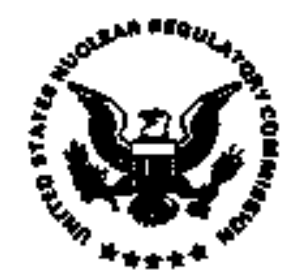

\author{
UNWTEO STATES \\ NUCLEAR REGULATORY COMMHSSION \\ masmingtow, 0. C. 20035
}

\author{
APPROYAL RECORD \\ Nodel No. TRUPACT-II Package \\ Certificate of Compliance No. 9218 \\ Revisjon Ho. 4
}

By application dated Septenber 24, 1992, Nuclear Packaging, Inc., on behalf of the Department of Energy (DOE), requested an anondment to Certificate of Compliance Mo. 9218, for the Model Ho. TRUPACT-II package. The request included the following changes: (1) a new secondary container which could be used as an overpack for 55-gailon drums or standard waste boxes (SWBS), and (2) revision of several content codes to include additional waste materials.

In order to address the potential issue of waste retrieval from WIPP, a ten drun overpack (TDOP) was developed wich could be used to overpack the retrieved waste containers, either 55-gallon druas or SuBs. This would allow the shfpment of waste containers whtch aay have been daraged during storage. One SWB or ten 55-gallon druns can fit inside the TDOP. The appltcant evaluated the decay heat liafts for each shipping category, to assure that the hydrogen concentration within the innermost confinement layer would not exceed 5\% durfing a 60 day shiphent period. The evaluation demonstrated that all shipping categories could be shipped inside the TDOP with no reduction in the decay heat per 55-gallon drum or per SWB. This is because there are fewer 55gallon drums and SWBs per package when shipped in a TDOP. Each TBOP must be equipped with a ainimuth of 9 fijtered vents, as described in Appendix 1.3 .7 of the application.

The applitcant provided descriptions. for the revised content codes. The new content codes are for waste for the WIPP experiaental progran. The revised. content codes include combinations of wastes from other content codes. The waste restrictions, chenical compatibility, and acceptable package configurations were determined using methodology used for other content codes. Decay heat limits were based on the most restrictive content code.

The Certificate of Conpliance has been revised to specify the packaging configurations authorized for the TRUPACT-II, and to inciude the TDOP as an overpack for drums and SNBs. The certificate has been revised to reference the updated TRucoul docunent, which includes the revised content codes. The certificate holder has been changed to the Transportation a Packaging Safety Otvistion of the DOE, based on a prevtous agreement between NRC and DDE.

These changes do not affect the ability of the package to meet the requirewents of 10 CFR Part 71 .

Date

NOV $1 \div 1992$

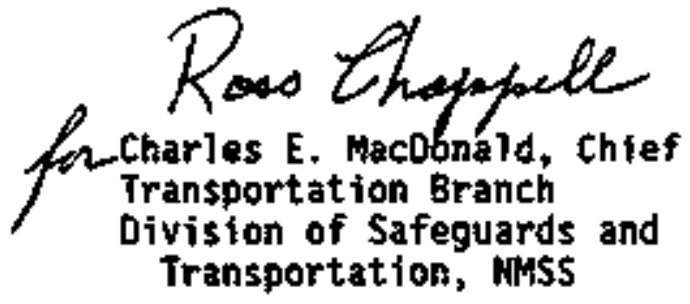




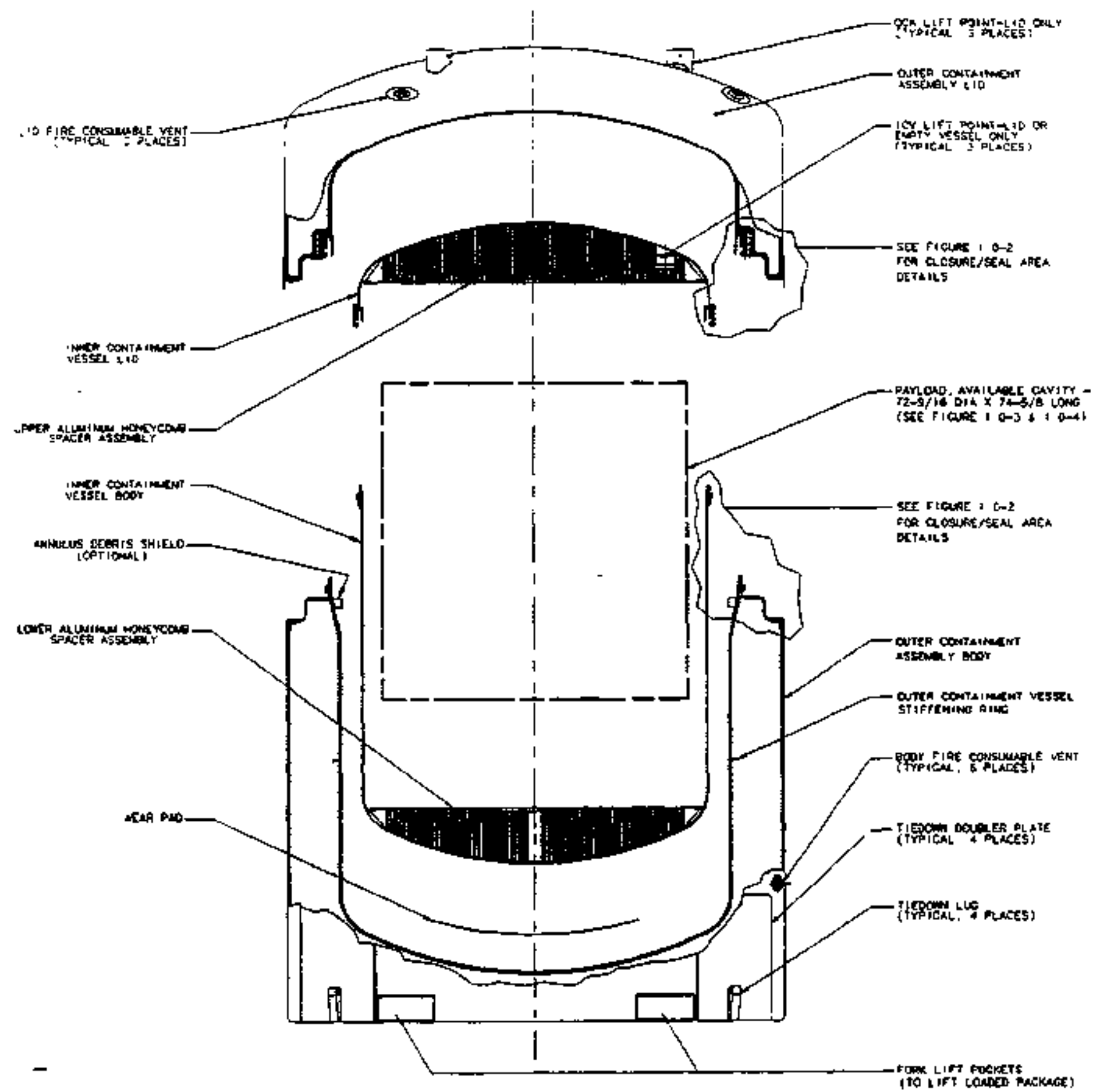

TRUPACT-II PACKAGTNG COMPONENTS 


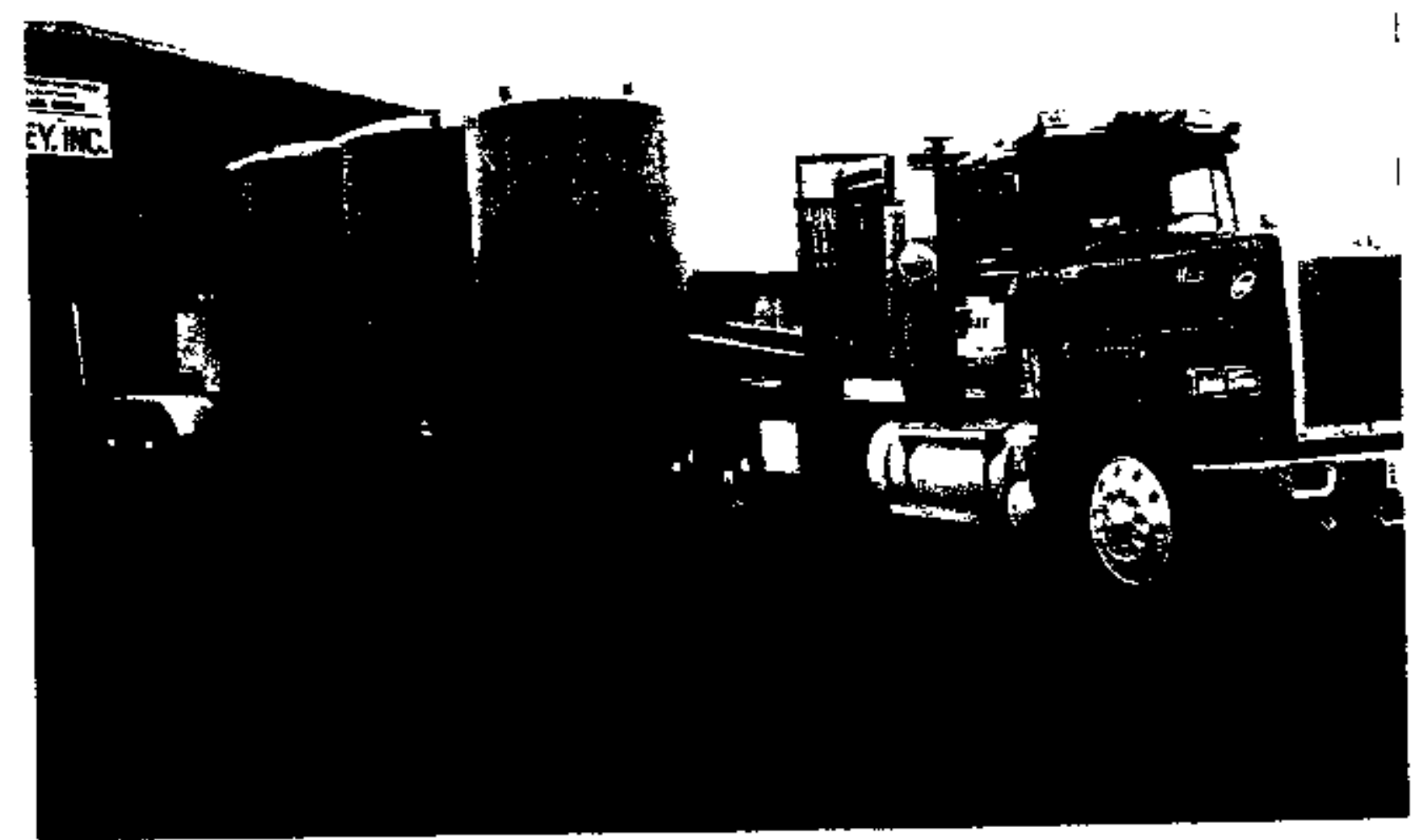




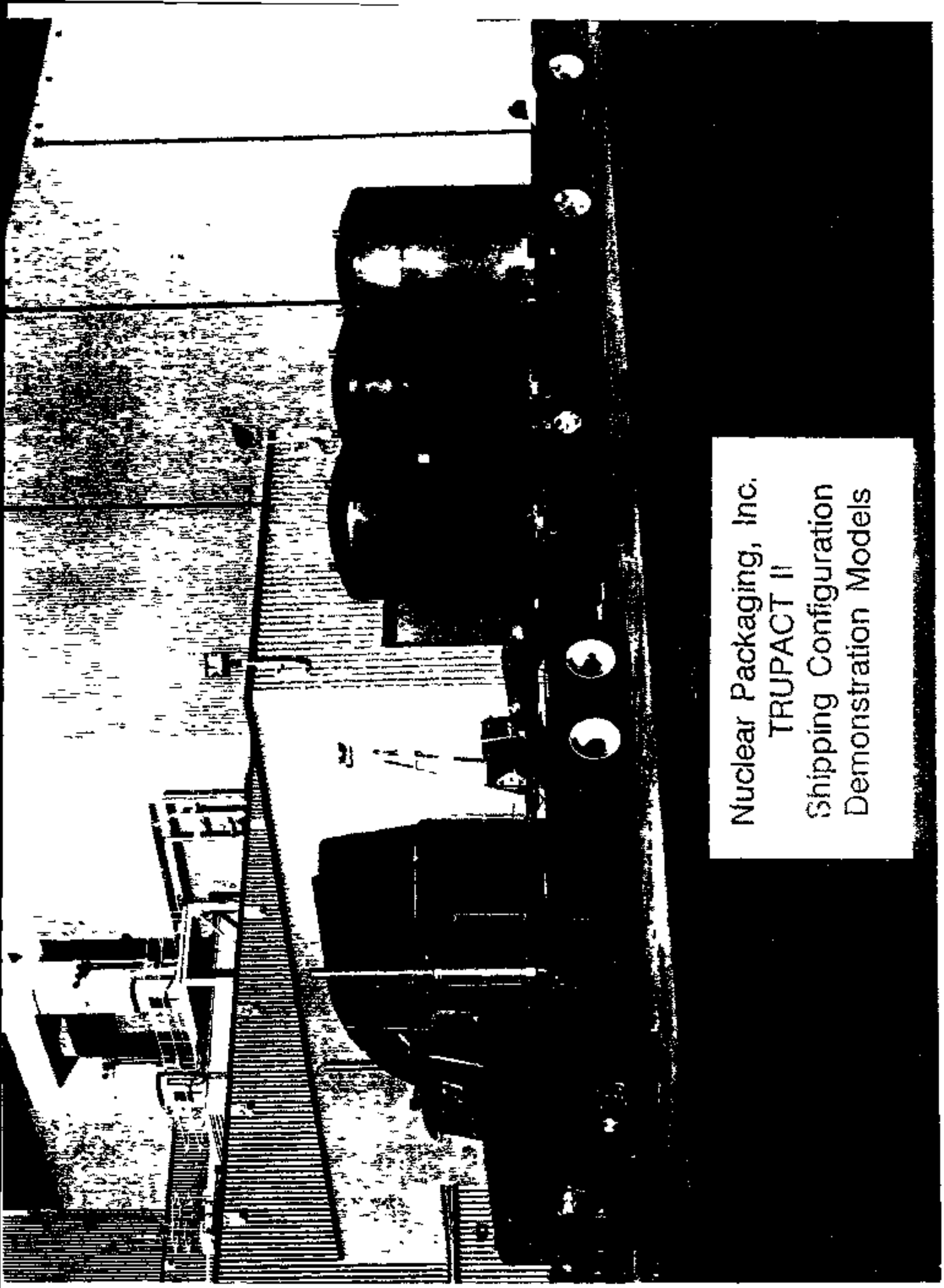




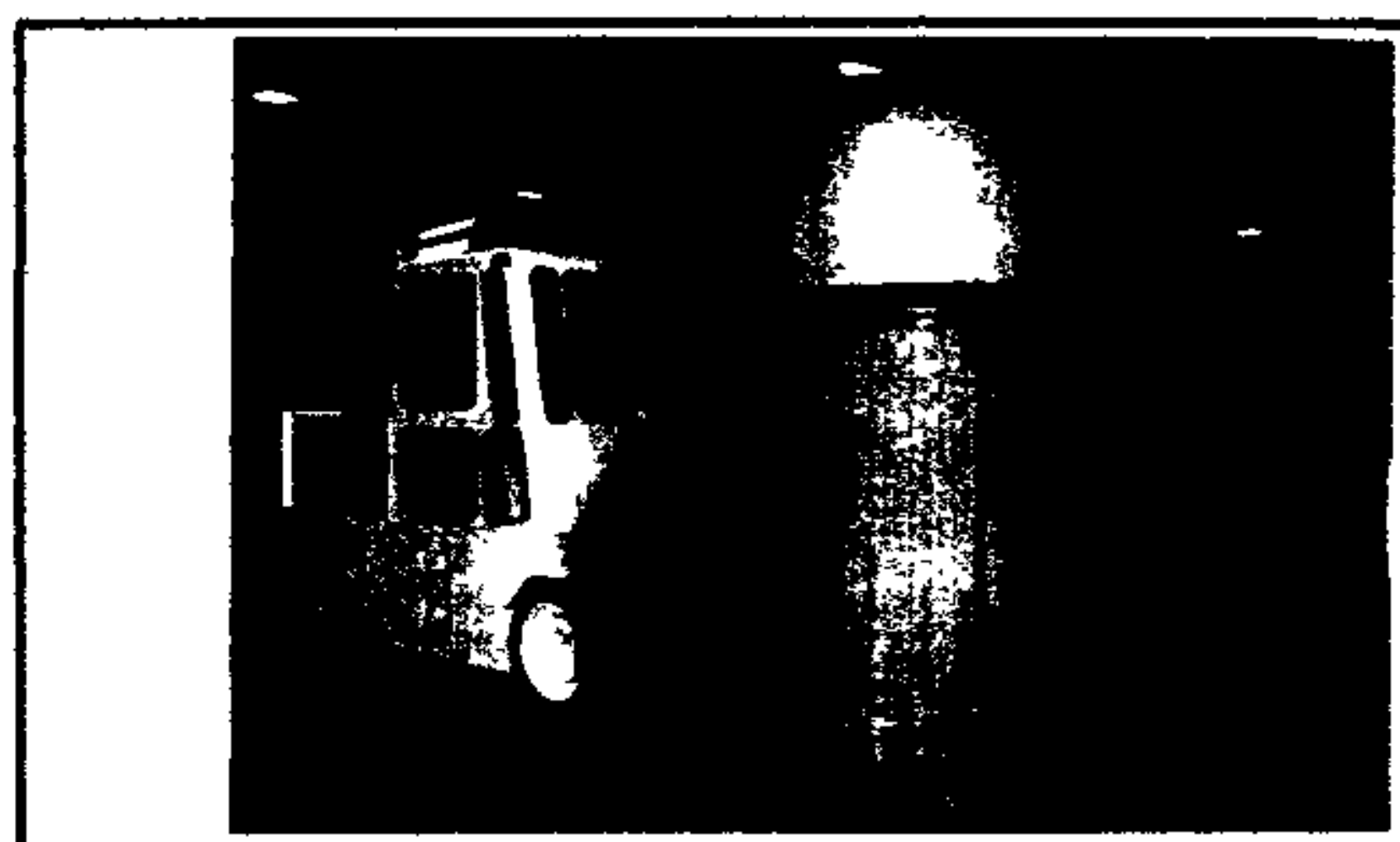

\section{TAUPACT I HANDLNG}

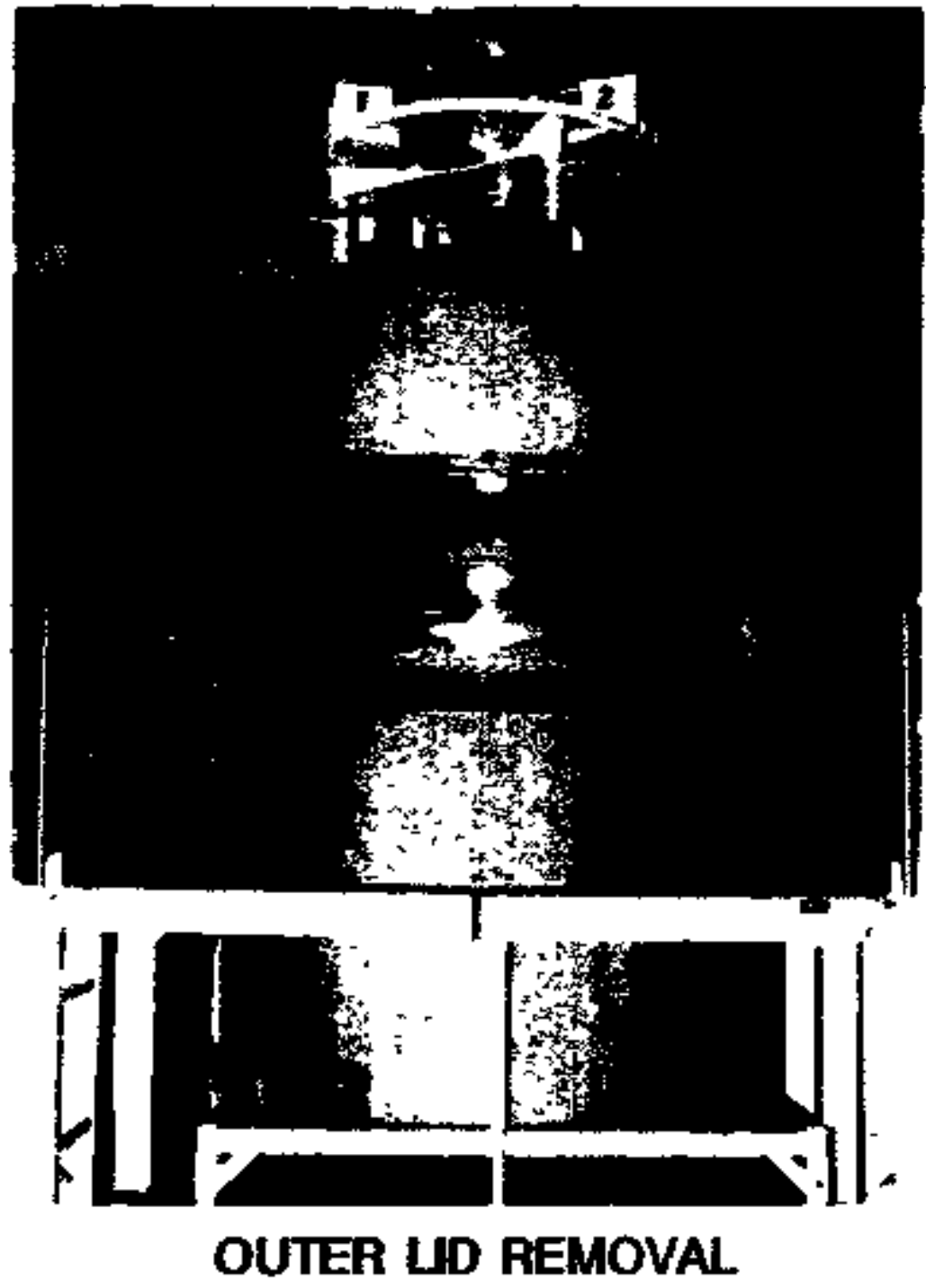




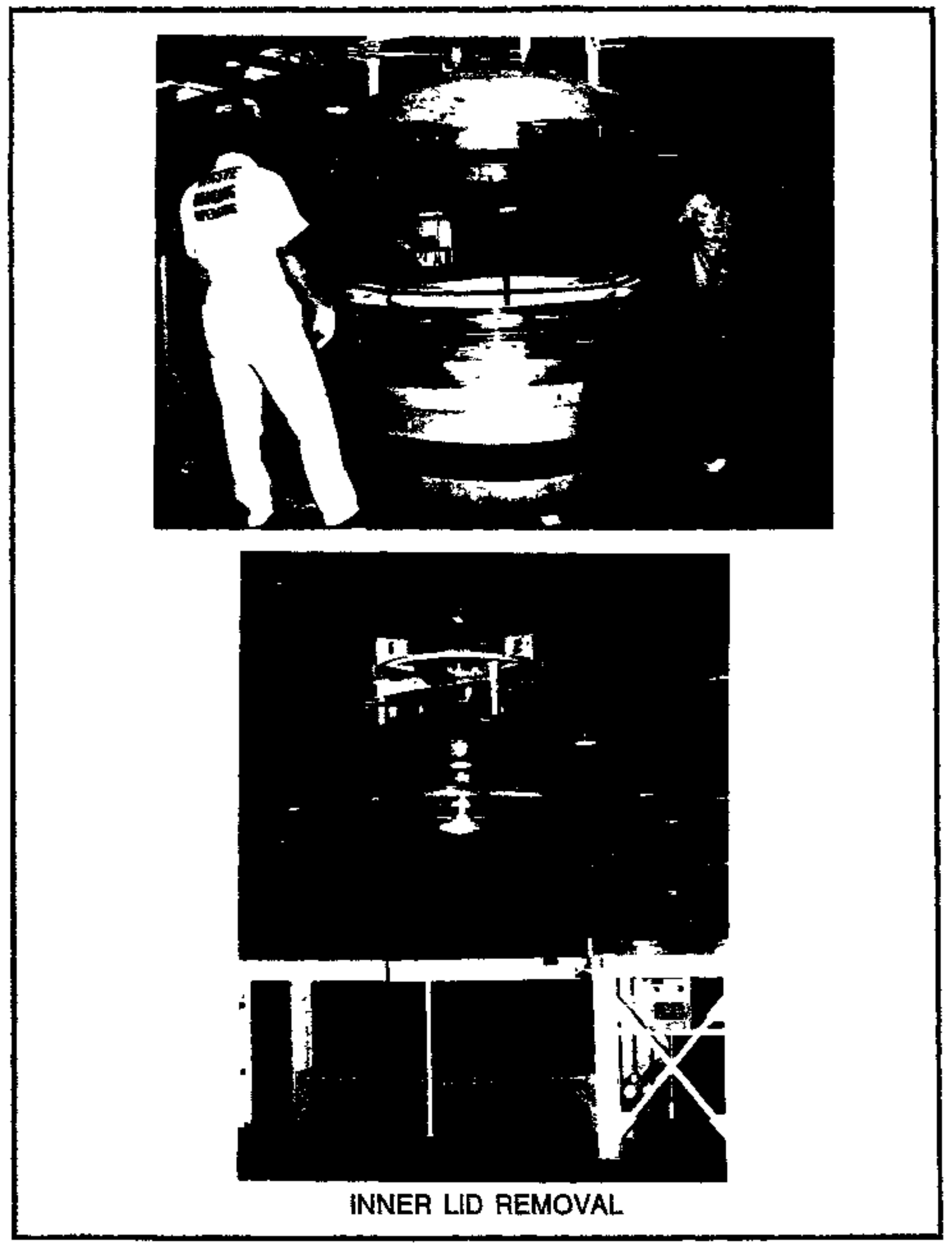




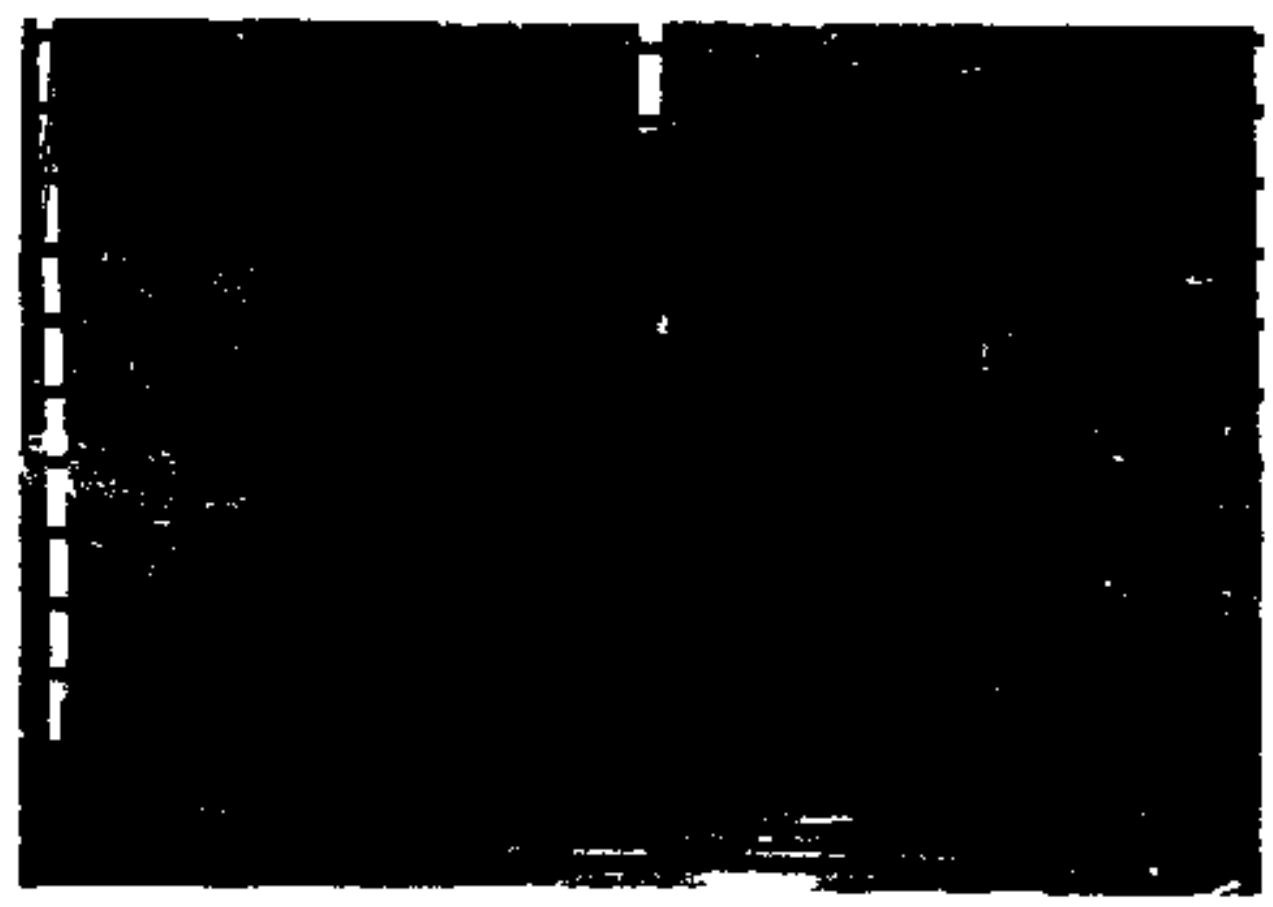

30 FT. DROP TEST IMPACT

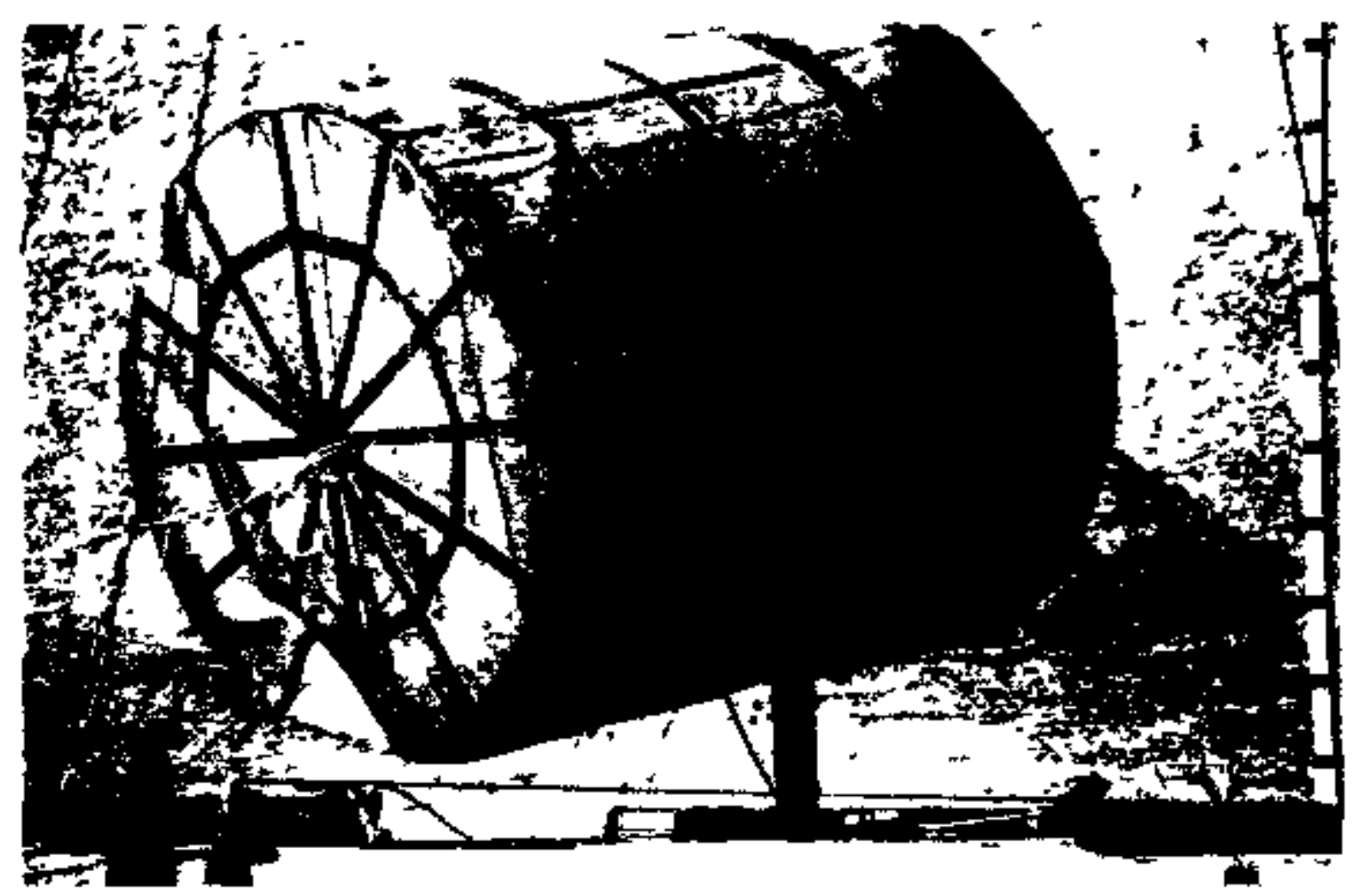

OBLIQUE PIN DROP TEST IMPACT 


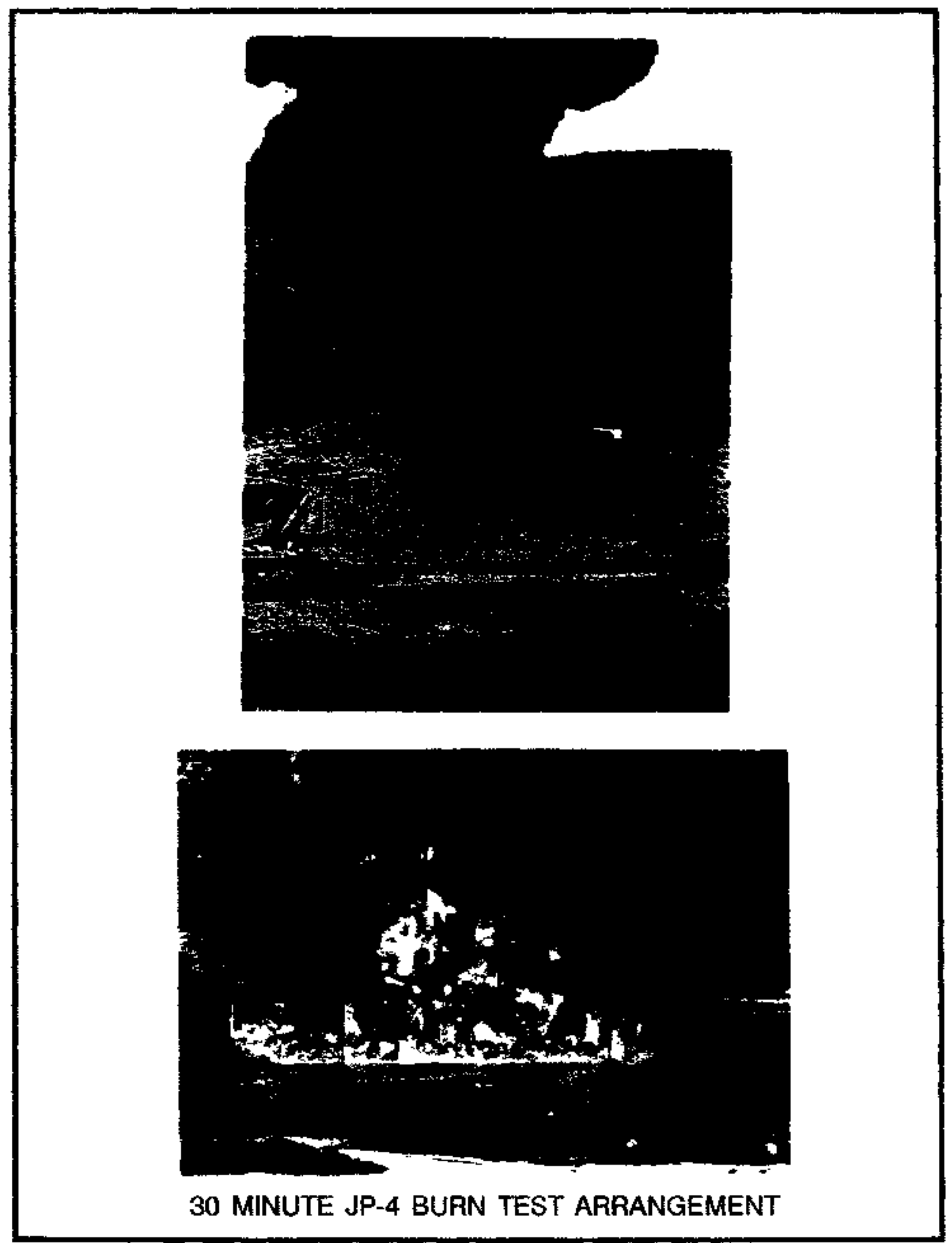




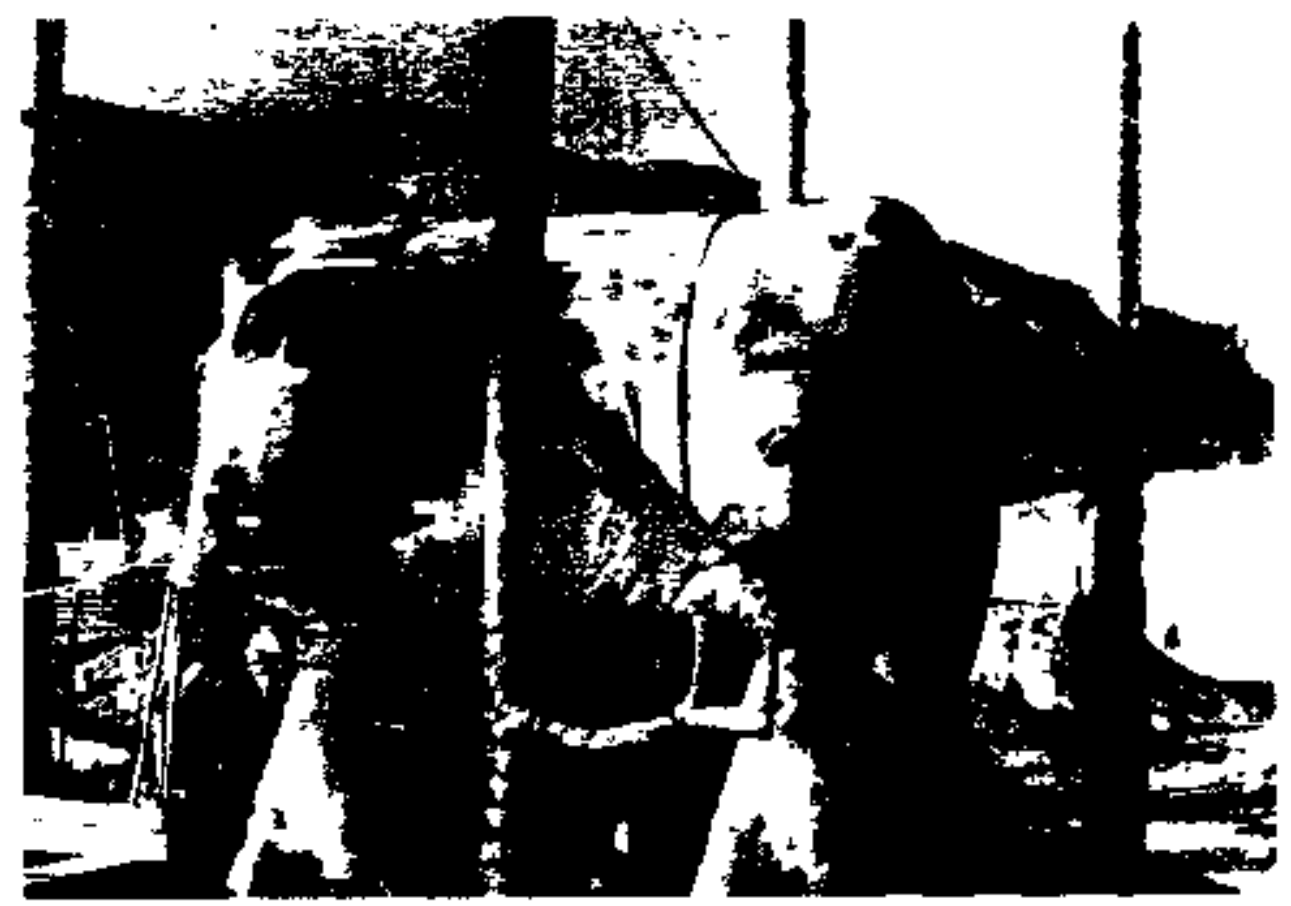

POST 30 MIN. BURN TEST

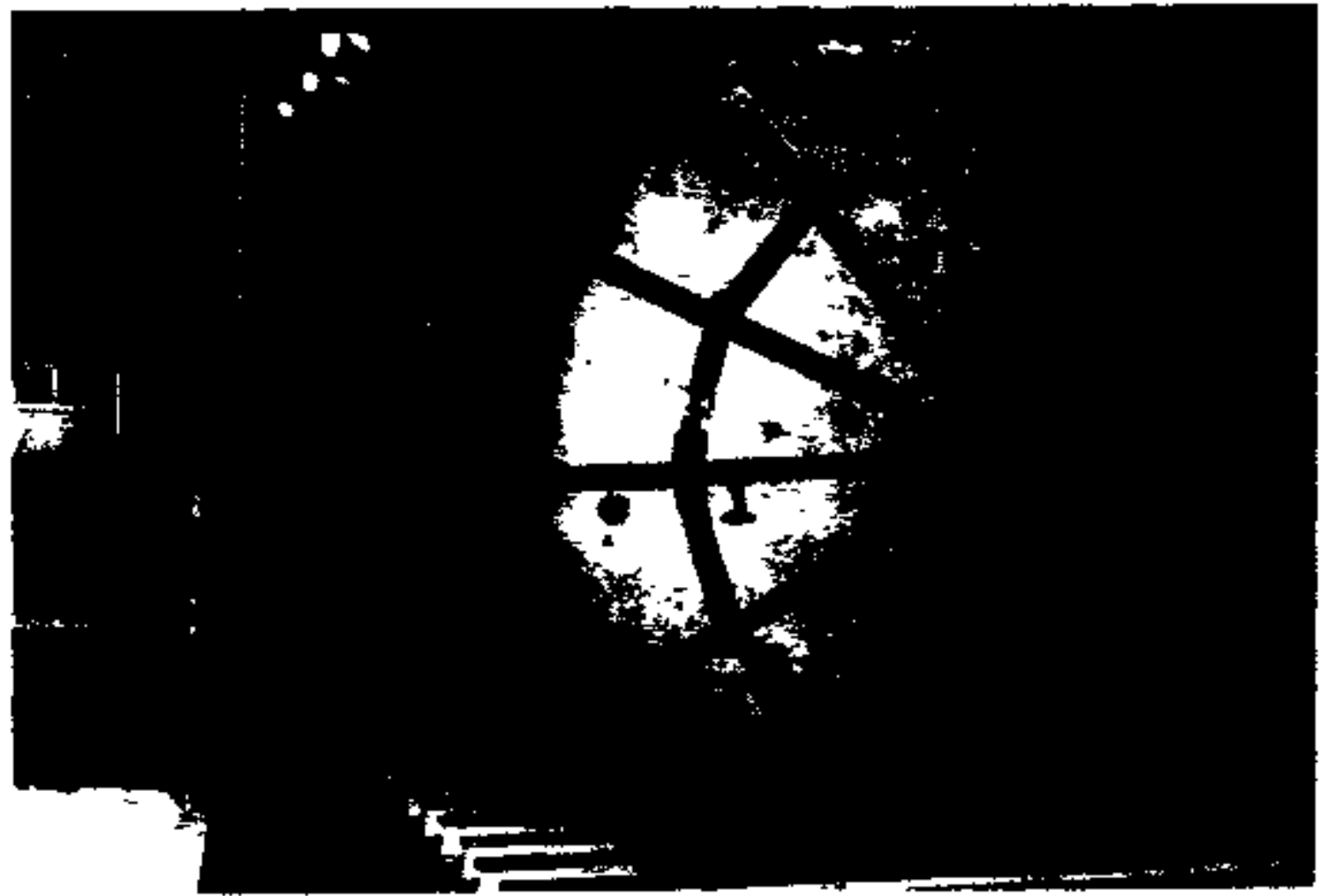

$.20^{\circ} \mathrm{F}$ COOLDOWN PRIOR TO $30 \mathrm{FT}$. DROP TEST 
Appendix C-2

NuPac 125-B Reference Article-ThI Shipments 


\title{
TMI-2 RAIL CASK AND RAILCAR MAINTENANCE
}

\author{
MJ. Tyacke, A.L. Aycrs, br. \\ EG\&G Idaho, Inc \\ Idabo National Engidecering Laborzlory \\ Idaho Fails, Idaho 83415 \\ L.J. Ball \\ EG\&G ldabo, inc. \\ Idabo National Engincering L-aberatory \\ Middletown, Penasylvania 17057
}

\begin{abstract}
This paper describes the NaPac 125-B cask system (i.c., cask and reilcar), and the maintenance and inspection tequirements for that system. The paper diseusses the opermions being done to selivfy thase requirements and how, in some cases, it has been elficient for the operations to be more rigorous than the requirements. Finally, this paper discuses the experiences gained from tbose operations and bow specific hardware and procodural cahancemcats bave restuled in s reliabic and continuous shippinis campaiton.
\end{abstract}

\section{IMTRODUCTION}

EG\&G ldaho, Ince, ncting on behaif of the U.S. Departmoal of Energy (DOE), is rosponsible for aceceptiag corc detris from. Three Mile Island-Unit 2 (TM -2) operated by GPU Nucisear Corporation, and lransporting it from Three Mile Lland (TMI) near Harrisburs. PA, to the ldabo $\mathrm{Na-}$ fonal Engincering Laboralory (INEL) near ldaho Falks, D. EG\&G Ideho, toc. also is responsible for placing the wabris in storage and toonitoring the debris. Transportalion the debris is being actomplished usiog threc Model 125: BRevi Cask systerns, which were desigped and fabricated. by Nuclear Packaging, Ince (NoPac) and certified for transporting the TMI-2 corc by ibe U.S. Nucicar Regulutory Commission (NRC). Shipments were initis!ed in July 1986, wed through December 1987, twenty-two cask loads have besa delivered to the INEL. That represents about ons-hall of the projected core volume.

Infoction and maintenance activities have been estabHighed for both the transport package and the rzilcar. Minfmann mainatenano requirements for the transport package te set Jorth in the Safery Analysis Repor (SAR) for lbe paetrese and issued by the NRC as a condinion of the pack. apertification. Mainlenano of the railear is set up to setisfy the Association of Amcrican Ratilzoods (AAR) rogiturements for taterchange servite. The actual inspection Yot m mintenace activitios are performed by several orfomiations. Maintenance of the transport paciage is per. Strined primarity by GPU Nuckear at TMI in copjenction 呵 the cask losding operations, and, to a lester extent, by EGstG Idaho, Inc at INEL, is conjunenton with the cask bouding operations.

Union Pacific Railroad (UPRR) is performing the rail. car maintenance at its car mainlenance facility located in Pócielello, ID.

The experience gatined from the inspection and maipGingace effort is of particulas significance because it relates bow the cask and sailear requircticnts are aclually being ac- conplished Io some cases the activities are much more rigorous than those normally thought equired in im. plementing sirailar transport actions. The experience gained is discussted in the following sections.

\section{RAIL CASK MAINTENANCE}

\section{Package Descrixion}

The NuPac 125-B package is a doubto-contatinmeat cask system wilh scparate and independent inner and ouser "leaklight" vessels (see Fig. 1). Fich vessel uses a doubte Oring mate/female seal arrangement designed into the bore of the vessel opening. The liof for each vessel contains ports for vanking the vesset, for testing the region between be $\mathrm{O}$ rings on the Jite scal, and for containing a rupture disc pressure relicf assembly. The inerer ressel contains sever centisler cuvitics, with ons cavity in the center and six cluslered around the peripbery. The asscmbied vessel also includes radiation shield pluos in the upper end of each canister cavity and passive impact liositer subassemblies at boch the bottom and tho top of each anvity. The shieid plugs allow "hands on" instaliation and testing of tho lid. The intpact limiters art destipot to limit axil loading of the core debris camisters in the unlikely event of a severe dyanmic transport iscident. Tbe lower impact limiters are separate subussembities, The upper impast timiters are integral with the shield plugs.

The outer vessel is a composite stainiess steel and lead asscenbly which covelops the inner vessel. It intorpotates three sels of heavy trunsions. Two sets are used for support of the cask assembly in its transport skid and the thiro for rotating the cestk from the horizootal to the vertical in its skid and for lifting the cask from the stid.

The cask system incorporates large-diameter fosmfilled overpacks attached at each end of the outer vessed, wtich gives the package the distinclive "dumbbel" atpearance. Each system also inciudes a transport skid, which 


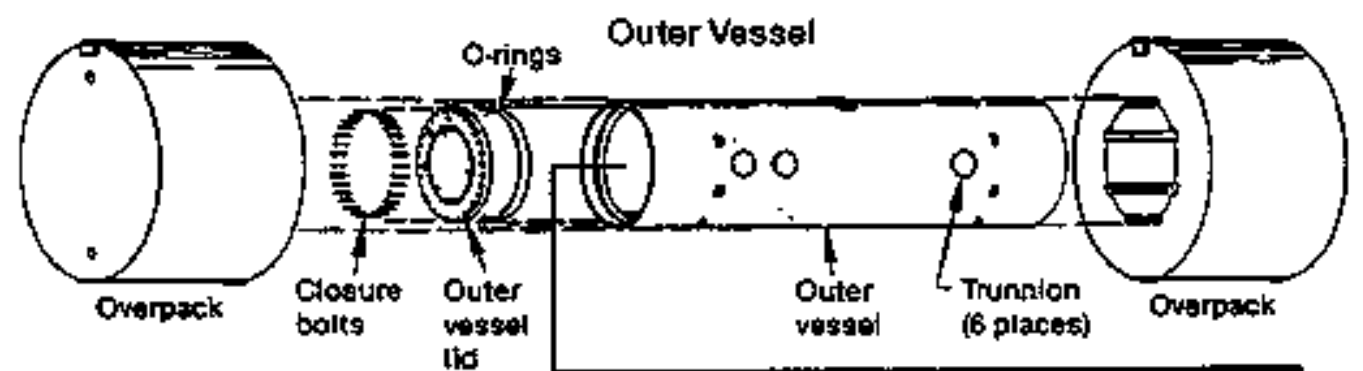

tid

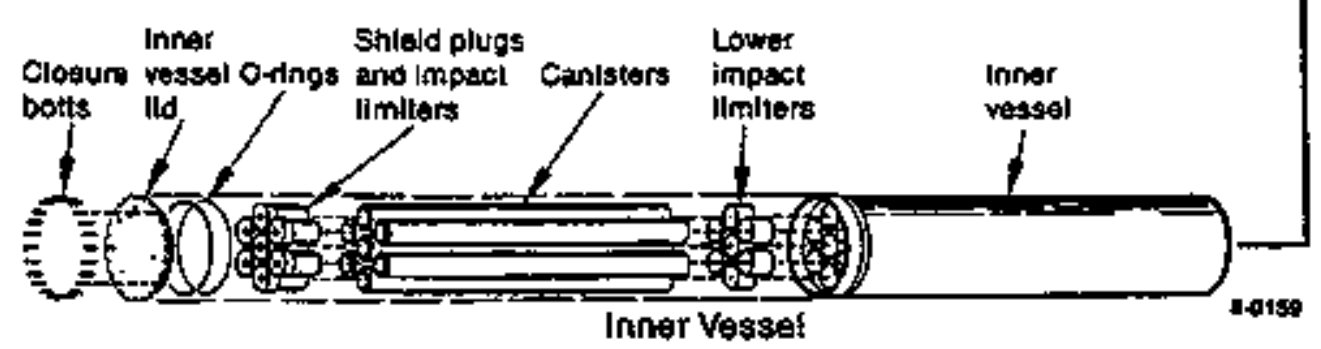

Fig. 1. Exploded View of the NuPac 125-B Railcask.

subesecmblies. The upper impacl liniters are integral with the striedd pluges.

The outer vessel is a composine slaintess steel and lend wsembly which eqvelops the inner vessel. It incorporates three sets of heavy trunnitors. Two sets are used for support of the ask astembly is its transpert skid and the lbird for rotating the cask from the horizandal to the vertical in its skid and for lifiting the cask from the skid.

The callis ststem incorporates large-diamcter formfilled orepacks atuched at each end of the ooter vessel, which gives the package the distinctive "dumbbell" apperance. Each system also includes a trensport skid, which functions as a multipurpose support syatem for the assembled pactanga.

\section{Crsk Maintensones Requirements}

The cortification by NRC fot the cast stipulates the itcers requiring meintenance (1). Those itcms requiring regular atteation, (ite, in conjundtion with eack use) and the actious tequired, tre as fottows:

- Eveteners-lnspert for general overall condition and for stripped or damaged threads before each use. Damaged fasteners sball be replaced.

- Omenoncts--lospect foe shipping dorrage and for stripped of damaged threads at the attachment points. A plustic pipe plug on the ead of each overpack shall be inspected for damage, and replaced if necessary.
- Trmnions-Inspect the trumnion bearing surfaces Cor cxicestive wear, signs of galling, or distortion.

- Sefals--Inspect the surfaces of all seals for tears aicks, or cuts, Darneged steils shall be replaced.

Those items requiring periodic maintenance aud the setious required are as follows:

- Eustenies-Fasteners (iroez and outer vessel lid bolts and overpack attachment bolts) shall be sepinced when demaged or, as a minimum, cvery five years.

- Seak-Seals shall be replaced anuually or wben darrageo. In conjusetion with seat tepiacement, sealing surfaces and O-ring grooves sball be inspected for damaging bours of kralches.

- Ruptmre Discos. The rupture disto for the insere and outer vessel lids shal be replaced annually or whed damaged.

- Imeer Impsct Limiters-The inner vessel izupact liniters shall be inspected annually for damage to the extemat skins and for axiat deformstions in excess of 10\%. Skin damage shall be correcled before turther use and permanent axial deforma* tions in excess of $10 \%$ strall constikute aced ior replacement of the impont limiter.

\section{Cask Operations and Maintenanct}

The actual maintenance of the catt is more involved than implied by the requirements. GPU Nuclear bas implemenled the following procedures in preparation for cach shipapent: Decontaminating the cask inner vessel internal 
eurfaces, including tbe impact limiters and undersicte of the incr vessel lid; replacing the lid scals; inspecting and repairing the ioveranl impect linaiters, as requiet EC\&G Idato, loc. has also implemented procedures for remoring residual water remaining in the cenister cavities of the inner vesel after unlonding the cask and for inuposting the entak trunions. Those activities require careful consideration wiea ptenning a shipping campaign of this typa.

Some backgroued iaformation about the TMi-2 shipmenls is necrstsary to understand the ratintenance operatoros. First, eadi cask is covered during shipnent with a reinforced vinyl tarp, referred to as the "environmental corw." The concr kecps the package and skid clean during Iransport, particulariy during the winter. Second, each cask is both beded and tunlouded using dry operations SpecialIt desigaed ensk interface and cariscer transfer equipment is ued for losding operations a TMM! and a large bol shop facility is ased for unioading operation at INEt. Those operations have confined package contamination to interior yurfaces of the inoer vessel, shistd pluges and internal impast limiters. Finally, each cask and transport skid is remoned (rom the raitcar both it TMI (loading) and (be :INEl (unloading). Upos receipt at both localions, the rait cask is inspected for shipping damege. The trvircamental coter and owerpacks are then semoved. At TMI, the reiles is mowed into the Fuel Handling Building where the cast. and transport skid are removed from tbe trikear and the car is removed from the building. At INEl, the ask and tzansport skid are moved from the railcar to ltractorftratler transpoter syatem for transport to the hot shop. The environimented covers, overpacks, and overpeck attrehment bolts are inspected at both locations subeequent to the removisl operalions.

Mainucrance at TMI begins after the cask has been moved into the Fuel Handling Building, aprighted in the skid, anchored in place, snd a moveble work stand ploced around the cisk. Lids of the censk are remowed, the inner ves. sel lid is surweyed for contamination, and the lid is decontaminaled. Shield phugs and impact limiters ate removed from the inner wessel. The interior of the ressel is deconlaminaled using hot water, followed by a lorced air orying cyeter. The seal surfaces on the inner and outer vestets are cleaned and irspeced. The impact limiters are decon. tarrinated and inspected for evidence of arial deformacion and damage to the skins. It should be noked thal the impacl timiters have required entepsive maintenance becanse of

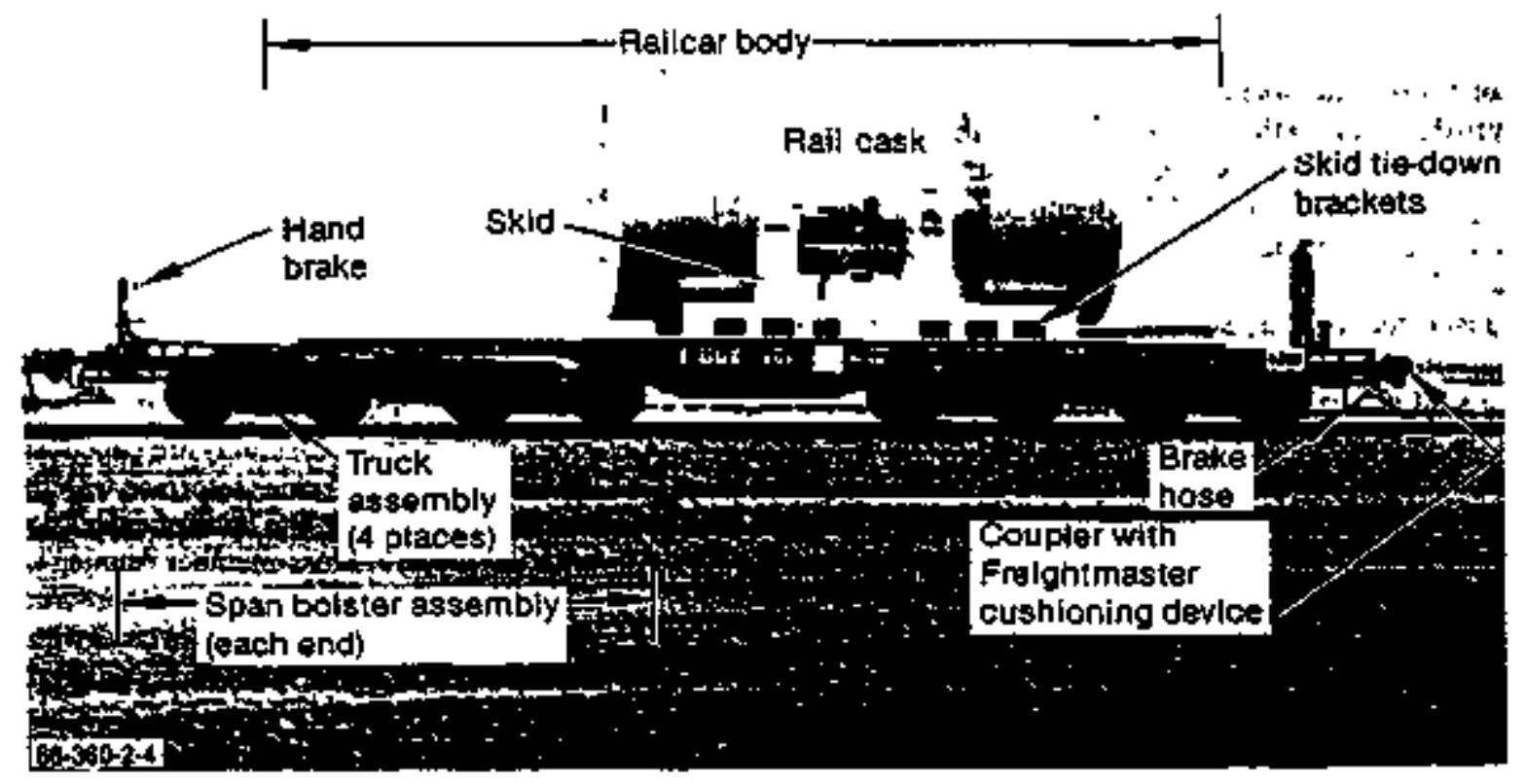

Fig. 2. The NaPac 125-B Trantoport Paringe With Reijear. 
$\times 10^{-7}$ atm-cots of gas at a pressure differential of 1 atm across the pressure boundary (a bubble about tbe size of a Pint-Pon bull per year)]. NuPacprovided (wo lest-test 5yztems for the paclages. The first, thelium mass spectroeneter leak detection syotem, is used for "maisiensace verfifention" lesk testing and has a seossitivity in the $10^{-7}$ to $10^{79} \mathrm{~atm}-\mathrm{co} / \mathrm{s}$ fange. The secood, a leas sensitive "pressure rise" system, whas istended as a "goino-po" test for "assembly verifiction" of the seals during normal operarions in the periods between set midtenance and replacement. Sipe GPU Nuclear replaces the seals after cacb shipmeat, the second \$ytem is not used and a maintentance verification letak test is porformed betore ench shipment. The helium leak detertion system is also used to verify rupture dise integrity after new dises are installed.

The cast inspection and maintenance at IN-佂 begin after the east has been transported to the hot shop, oprighted and fifted from the skid, and placed in a stationary porkstand. Onco the cask is in the stand, the lids are remoned, set asides and protected. The fid bolts are cleanod, intpected, and set atide. Platic rings are installed in the eask vessels to proteat seal surfaces and phastic is draped over the top and sides of the cask to reduce possible contomisation. The bot shop is then cleared of operatine per. sonined and the canitisters are wilbdrawn remotely from the cask ind placed in storage.

Alter the cask is unfouded, clcanup activities ure intiated prior to cask assombly. Even though the easks are dry beded at TMI, the conister surfaces are not completely dry efter removal from the storage pool and some water is carried into the eask. The shield pluges and tower isopact limiters tre removed from each canister cavity and the recidual water is remowed usizs sbeorbenl rags on the tind of a long rod. Radiological smears are obtained from oach caviky to dekermise if the costamination levels are below the requirements for tekn shiparent of an emply cask. If recuired, individual crvities will be decontaminaled The impact limiters and shiekd pluss are wiped and reinstalled into the cask. The plastic confers are remoned, seaik and seat surlaces inspected, and the lids installed. The upper two poirs of trunnions are inspected. The lower ser of trannions esch have splin slecte bearing and housing installed over the trunnion bearing surface. These bearing assemblies are removed lor inspections semiannually.

\section{RAILCAR MAITIENANCE}

\section{Raticar Description}

The raikers are 149.7 motric too (165 lon) rated flot deckers. Figure 2 is a phokograph of an astembled ratit cark system with callouts added to identify the major subas. semblins. As shown in the phoxograph, each ead of the flat deck body interiaces with a "span botster" assembly. The spas bolster is a beany Irathe assembly which distribules the load at each ead of the car body equally berween nwo "Irock" assemebties and articulates the movements between the car body, trucks, and coupler. Fach track assembly distributes ins load equaily between rwo axtes, so that ultiraxcly, the foad from the fuilear and cask ussembly are distriboted between two span bolsters, four trudks, ejght adks, and sinteen wheek. To undersiond the maintenance on the railear, special fentures of several raikear subassemblies are described as follows:

- Car Body--The underside of each end of the car body has a thick circular plate, known as the "center plate," welled into the the body strockure. That plate serves as cie connectiog pin berween the body and the span boisler. Outbourd trom each center plate, (ive, loward the sides of the $\Leftrightarrow x$ ), are small rectangular "wear plates" webded to the body underttructure which mate with similar plates on top of the span bolster. Those mating pairs of plates are known as "side bear. ings," sod they function to limil till of the car body relative to the span bolster. When lhe car is level, there is a spectified clearanee belwees the surfaces of the side bearing wear plates.

- Span Bolster.-The receptacle in the spon boliser which interfoes wilh the car body conler plate is known the the "cencer bow" The mating surfaces of the exnter plate are surface hardenod, so the enter bow is lipod with " "water rinst around its vertical bore and with a wear plate in the bottom of the bowl. A beavy lubricant is applied to the wetar plate to peovide a bearing material in the assembied conncetion. The underside of the spon bolster $\$$ the inter lace with cach rail trivek is simitar to the car body conifguralion (i.c, cenlex piate and side bearings).

The frame of the span bolster is extended al one end to provide an interlace wilh the railcar coupler system. The span-bolster frame is built to accommodate a "Treightmaster" draubar cushioning dovice and the Freightmaster unit, in turn accepts a standard railear coupler uait.

- BailTencks--The structures on the outhoard sides of each (ritek assembly are calkd "side frames." The side frames interface with the roller besting housings on the ends of each ate and with a scructural cooss-membet running acoss the center of the truek, known as the "truck bolster." The truck bolster interfaces with exch side frame through a set of fincar guides and the fail truck spring assemblies. Exch truck bolster contains a center bow for the respoctive span bolster center piate and these are side bearings to linit the tilt $\alpha$ the span bolster relative to the 
truck The truck assemblies also contain alt the mechanisms, linkages, and air oytinders neces. sary for the brakes, which interlace wilb each wheel

\section{Railcar Mainlenance and inspedign Requirements}

EGRG Idaho, inc and UPRR estabtisbed two raiker inspection checklists. The first is used by the UPRR inspector for inspectioes at INEL before accepting the cars for return to Thit. The second detsils the inspections and preventive maintenance periormed by UPRR al its car minicenance facility in Poxpteilo, ID. All items on booh chetlists cither meet or are more rescrictive than the rC. Trirements set fortb in the Ficld Magagi of the litcritange Rake, 1987, elopted by the AAR Mechanical Division Operations and Mainteniance Department (2). Three items which are more restrictive than the AAR requirements are: (a) Replacemest of the brake shoes if there are signs of near, (ze, crateks or half of tbe brake material thickmess thas been used); (b) average clearances of side bearing for each of the fous rail truck bolsters must be between $0.4 \$$ and 0.64 con (3/16 and 1/4 in ); and (c) magnillex of whod tread for signs of thermal cracting [each ser of whects (axdes) is teituted about every $80,500 \mathrm{~km}(\$ 0,000$ atiles) to ensture miform wear of tread].

The following is a stemmary of the detailed iaspection and proventive mainicnance chocktist parformed at the maintenance stop of UPRR. The AAR Rulas fotlowed for soceptasuce are induded, where appropriale. An explaces. ton of those rules can be foumd in Ref. 2

- Coupler Assembily--Check couplers and inuck. kes for worn or distorted contour (AAR Rule 16). Ensure correct knucicle is being used (AAR Rule 16). Remowe cesh coupler and check shiank wcar (Fig.D of AAR Rule 16). Remowe and inspect knuctite pin, Insperd draft key [condemr. when wore 00 any sioe $0.64 \mathrm{~cm}(1 / 4 \mathrm{in}$ ) or morc]. Check coupler side clearance and lop vertical clearance (Fig. 5 of AAR Rule 16). Afler reassembly, cbeck and secord the coupler baight from the top of rail and toggle eleserance. Uncoupling mechanism mest comply with AAR Ruie 22 Intpeca Freightmaster eushioning device. (Freighumaster manulal - pages 6, 7, and 8, and AAR Rult 59, Section A). Check accessible parts of Freightmaster backstop casting.

- Brakes--Inspect and replace defective air brake hoses [AAR Rule 5 (R ule S.A.t.h docs por apply)]. Hoses moust be changed every fout ycars. Check air line brackets, supports, angle cocks, and piping. Inspeet brake keters, brake besm. guides, rods, and pins (AAR Rules 6,9, and 10). Perforn singe car air brake test (pamphict 50394, Sup. L, laiest edition). Inspect brake sboeschange when worn to $1.9 \mathrm{~cm}(3 / 4 \mathrm{in})$ or bess
[AAR Rule 12 (does pot iactude Rula 12A.5)], Inspeet til beake conoection pins and cotters (AAR Rufe 9). Inspect all bocty brake rigging (AAR Rukc 11). Record COT\&S (Clean, Oill, Tast, and Stancil) dite.

- Span Bolster--inspect span and boojy bolsters, and centex plate for crocked or broken members. Apply center plate lube. Mesisure the side beating clearance at two places between tho car and spas bolsters at each eod of the car. The average of the two dearacess must be betriece 0.37 and $0.48 \mathrm{~cm}$ ( $1 / 8$ and $3 / 16$ in.). Measure the side betring ciearance at two places betwets each of the spac bolsters and four truck bolkters. The average of the two clearances must be between 0.48 and 0.64 can (3/16 and $1 / 4 \mathrm{in}$ ).

- Tnick Assembly-Inspect truet bolsters and side frames for worn, broken, cracked, bent, pakched, or corroded parts (AAR Rules 47 and 48). Check wheeis for virual damage. Inspect and gage whoels and condemb at $27 \mathrm{~cm}$ (1- 1/16 in), (AAR Rnle 41, Rule 41_Al.w does not appty). All wheet creads will be magnillutod, UPRR specitication. Each roller bearing shall be hand rotated and inspected for daminge, unusual fect, or sound (applicable sections of AAR Rule 36). Inspect roller beariug tadapiers (AAR Rule 37). Check for brotsen, missing or out of position truek springs and snabbers. Mensure and record mininaum alcarance betwoen kowest poitt of truck and top of rail (must comply with AAR. Rilte 89A12).

- Car Body-Inspect car body side and center sifls and crossbcarcrs for cracked or broken members and for cracked watk.

- Remarks-The trspetetor records decessary measurements, dates, and signs off after each itcm tas been inspected. The Inepector records, dates, and signs off all repairs made to the car. A signature by the railrosd inspector certifies that the railear ineets or exceeds the requí the AAR and is aceepteble for usc.

\section{Railear On-Sile Inspoection}

The raticars undergo inspections before leaving ThI and TNEL, Inspecters from DOT/FRA inspect the railcar at TMI. At INEL, inspectors fram UPRR wse the INEL checklist, ecrtifying that the cempty return shipment is acexplablc. The UPRR inspectors will replace brake sboes, if required. Other defects are corrected at che UPRR main * tenanee facilitics.

\section{Railor Defatiled Inspection and Preventive Maintcpance}

The inspectivns and maintenanes being doot for the railears are much more rigorous than would normally be an- 
sicipaled Since the fars were acw at lhe start of the shipping campaign, RO\&G ldaho, Inc, and UPRR agsed to do complete inspections and preventive maintenance afier cach rail cask round trip, at least until the cars were through their tritial break-im periods and an operating history for ench car was estiblished. The inspections and prewentive maintenanoe eotailed a detailed tear-down inspection of cack car about evtry $8,000 \mathrm{~km}(5,000 \mathrm{mi})$. By the eed of the third trip for each car, the amount of corrective main. tenance beting performed had dropped and consistent operating litstories wero developing. UPRR and EG\&G Idaho, Inc. tive mainteanance would be changed to every third round trip, of abour $24,000 \mathrm{~km}$ (15,000 mi). The following brienly describes the activitis being perforroed at the UPRR maintenance facilities

In the mintenapese shop, each railcar is disestembled one end at a time. The body with cask is jecked up and the span bolster with trucks is rollod out. One end of lbe span bolster is Efted and the respective truck is rolled oun. The four braike shoes are removed and the shoe pack tare inspected. Exich ate is remowed from the truck, and the wheels are visually inspected for damage. The width and depth of the flange of each whet are messured. A magnifhux inspection of ech wheel is perionmed lo chect for therral erucken To provide uniform wear on 1 be (reed of the wheels, the wheels (ades) are ratated about every $80,500 \mathrm{~km}(50,000$ milos). The wheol besrings and adaplers are checked. The wle ascerably is moved back under the trusk. The adapter is placed on the rolles bearing. The truek is lowered onto the axto and the assembly lis bolits insenlled. The tole and name of maintenance yard where inspection and the wheels were fotated are slenciled on cach axle. The operation is repeated for each ade.

The teuck center bowl is inspected and cleaned, delects ropaired, and labe disks melted inside the bowl. Finally, the safety pin (a pian extending from lbe center of the bowi which engages a matching bore in the span bolster cealer plate) is inspected for dumage. The brake shocs are insialled, the brake bose connected to an air supply, and the brakes are operated. The atroke of the opersting oylinder is measured lo ensure the brakes operaling peonerly. The undersitle of the span bolster decte is inspected and if ucesssary repaired. The truck is then rolled back under and asterobled with the span bolster. The operations are repeated on the opposilc end of the span boister.

The span bolster center bowi and wear ring acc in. spected, and if nectssary, repaired. The lube malcriai on the wear plate is replaced with new lubricanl. The underside of the main body of the railicar deck is inspected for defects and if necessary, repaired. The span boister is rolied back tnder the main body of the railese deck. The eenter plute under the reilcat deck is lowered into the span bolster $\propto$ en- ter bowl. Clearances on the span bolster and lrokt side bearings are measured, adjusted, and recorded on the checklist.

The car coupler, kuockle, operating leter, and internal parts are disassembled Irore the Freighumastes coshioning device. They are inspected for worr or distorted contour areas, repuired, and reassembled. The eutire procedure is repeated for the opposite end of the car.

\section{MAINTENANCE EXPERIENCES}

As a result of the inspection and maintenance progeram performed on the NuPoc 125.B Rail Casks and railcars, there anere aumerous improvements made to the system which reduced the maintentance efforts. The shipping cimpoigg was initiated with two DOE.owned rzil casits, A third lessed cask, beilt and owned by NuPace entered service in Octobes 1987. The ingrovements were implemested in the third cosk system and are being insorporated in the original casks. This section discusses some of those intiprovements.

\section{Cask}

Working experience wilh the following fitems supgests improwements are required to decrease maintenance or incrcase clficiency, Both the ilems and the solutions atc discussed.

- Intermall monat Limitats-The internal iarped limiters use aluminum honeycomb for the energy absorption medis. The boncycointio is sratected from the cast internal environment by wrapping a thin (oonlond bearing) strindess stecl stocet around each assembly and setiling it to both the upper and lower stainless steel end pieces and along the longitudinal seam formed tit the ends of the shect. An cpoxy-based indus!tial adhesive was used to bond these skins onto the assemblies. The adhesive joints, however, are fail. ing and the seams require constant cleapup and tepair. To correct this sination in the third cosk, tho skin thieknoss wes increased slightly [from 0.01 to $0.023 \mathrm{~cm}(0.004$ to $0.008 \mathrm{in}$.) ) and the skins were wedded in place. Replacement units are being labricated for the originat two casks.

To remove waner front the eask wfler the eunisucrs are unloaded at iNEL, a smail-diameter tube was installed through the ecter of each lower impact limiter. The tulse allows fumping of residuat woter from cach cavily without renoving tbe impact liniter.

- Lamards-Smalt-diameter, vinyl-coated steel eireraft enbles (with crimp-tic securtiy loops) werc used as lanyards to allach remoral parts (i.te, pins) to the skid and raitear assemblits. The vinyl caating would break at the crimp-tic, and the tic and coating would slide ovet the cable, eausing the lanyard loop to open. The sisuation 


\section{Tyucke TMI-2 RAIL CASK ANO RAILCAR}

was corrected by using uncoatod stainiests ticel cables.

-

Dresacksatiostatlation of attachmicat bolts for the owerpoeks was awkward ond itme consuming. The bolls were toag heuvy, sad hard to mancerver into the blind holas in the overpocks, even though cosprse bolt guidet were provided over the length of the bolts. The siluation was corrcted by odding tapered lead-in collars around fach boit bole.

Railisar

The inspection and asinlenance program for the railcars has beasefitted both the campaigat and LPRR. Correc. tive aclions were taken on thate itcats of the railent which were identified as requiring excess maintenance. The experience gained trem the first two cors resulted in changes being made to the thitud railear. The tollowing is a discussion of the Hems requiring excesssive musintenance and the corrective actions taken.

- Excossinc Brake Shoc Renlacemenl-Brake sbues were being reploced too frequendy. The pads on the brake stows casked before wearing olf. Jnitially t was thoughr that (he hand brakes were being impeoperty released, bowever, the sinuation was bot corrcoted alter rigorous adminiturative conkrols were aslabilified A further evaluation showed the breake stoes to be laulty. The situation has been corrected by using brake shoes from another manufacturer.

- Excess Wear of the Whocl Tratis-UPRR noticed there was traad boitidup and exesssive grooving of the wheck. Evaluation of the situation ideatified the following thete caluses and solutions. First, be aetw cars were "stifl" and reeded a break-in period Second, imptoper relcase of the brakes caused wheets is drag thus crusing fat spexs folkowed by a tread boikdup. Adminisuative controls eliminated dragging of the wheels. And third, the Gars always travelled the same direction causing the wheels to become grooved. UPRR corrected this situation by ad. ding the rotating of the wheels cvery $80,500 \mathrm{~km}$ $(\$ 0,000)$ mi) to the preventive maintenance procedurcs. Thal action has made lbe treed wear untorm.

- Span foleter Center Bond Wear Ring CrackingThe tetar ring and its atcadument weld to the center bowi of the spas bolster were cracking. The situation was corrected by repairing and building up the welds bolding the wear rings in place. If that action does bot correct the situatiou, forged wear rings with a mochined press fit inlo the een(cr bowls will be installed.
- Till of lha-Railcar Bed-Afier operating the cars on the longer maintenance schedules, the dect: Wals developing a noticcable till. UPRR datermioed that the lube disks used in the truek center bowls were tou hard and faibed to compreas as designed. The motion of the railenr durints transport caused the sisk to tear at the center piaboic. The lube material would build up on one siode of the bowh, causing the bed lo tilt. The disk was replaced by a lube material which is melled into the bowl.

- Whock-The first two raitears wete deliveced with Grads "U' wheets which acoounts for the excess (read wear observed. The third tailcar was delivered with Grade "C" (berder tread migieriol) whock. The first cars will be equipped with Grede " $\mathrm{C}$ " whecks as the cristing wheels wett out.

\section{CONCLUSIONS}

The maintenance program implemeeted in the TMI shipping campaign hus heen efloctive in maintetining a reliable and continuous shipping scbedtule. As recogatzed earlier, the selual maintenonec being performed is not as simpte as first concetived but lbe qesults have been posstive, and with experiences bave becomescomewhat routine Many sublic cohancernenls in hardware aids and operating pro. cedures have been dexeloped since inception of the shipping opcrations, which bave contributed to the overall cfliciency of the operations. A fow of the maintenance progrant highlights are as follows:

Cask

- Cask Daconlamination-Decontrmination of the casks after each shipmear is a time-consuming operation but has proven to be effective in: Preventing the boildop of contamination in the casks and canisser-loaciog cquipment; minimizing the spread of comamination at both TMI and INEL, and; in keeping exposures to operating personact (and to a iester extent the pubiic) as low as reasonably achievable (AJ_ARA). Loading operations at the cask are in tacl ascomplished with only simocks, gioves, and sboe corers being wors as protective clothing

- Eare-Senls--The bore senl design utifited in the NuPac casks bas proves to be a viable and reli. able seal concept. The seals and seal surfaces are exsly mainained and provide consistent positive results.

- LakTesting--TMI experience has sbows the beliur leak-lesting procedure to be an effective and timely test method for use in cootine operations. It yields conclusive results and is 20 complished in the same or less lime than the less sensitive and qualitative pressure risc test 
method. This is aot intuitivefy obvious when first coasidering methods for testing seal integrity.

Raticar

UPRR has dedicated a senior and experienced maintenance crever to do the inspections and anintenance procedures on the three cask system raikars. This has been extremely beneficial for both parties (i.e, the same personts performing the matntenance are "tunced in" to lbe trends and characteristies developing in each of the cars and the main. tekense is performed cantistcatly and in a timcly manner). All inspections, minatenapce, and vecessary repairs are normally accomplished in one day and in a single shiti. - Highlights of the maintenance program are:

- Loner Whecl Lifo-Early dentifientiou of excess wheet weat resulted in timely procedores to grestly exand the useriv wheel life for the eats. Administrative cootrots corrected the improper release of the hand brakes. Also, the need for 3 harder grade of whed was factored into the re. quizements for the third cailcar.
- BrakeShnes-The consistcacy of the mitiotedence propram ellowed a thorough evaluation of the premature brake shoe replecement siluztion, which ultimately led to identifying the uste of latuy brake shoes. Union Pacilic bas notified the brake sboe manufacturer and has changed soppliers for replacement brake shoes.

\section{REFERENCES}

1. US. Nucles Reguietory Commission, Certificule of Cor. formance No. 9200 , Revision No. 4, for Model No. 125 . B Shjpping Pactapes, Docket No. 71-9200, October 28, 1987.

2. Associalion of American Railroads - Mechanical Division Operations and Maintennince Department, Field Manual of The Interchange Rules effeciovs Jabuary $\mathrm{L}, 1987$. 


\section{Appendix D \\ Backup Data for SNF Truck Shipments}

Appendlx D-1: TSMT Quotes (3)

Appendlx D-2: Nuclear Assurance Corporation, Cask Rates and Specifications

Appendlx D-3: Ceneral Atomics-Cask Rates and Specifications 

Appendix D-1

TSMT Quotes (3) 
PRINTED 05/04/99 14138128
THI-STATE HOTOR TRAHSIT, CO. QUDTINE SYSTEM - QUOTE INQUZAY nutitoos

PAeE 1

ALDTE MUMBER: 245026 ENTERED BYI SLH ENTERED: OS/04/93 COMPLETEDI 09/00/00

CUBT: NAHEI HORRISOH-KNUDSEH

CITY: SAN FRANCISCO, CA ZIPI 94100

CONTACT: PHIL KELLEHER OAIEINATEDI
ADD: FAX 415-442-7673

PHOWE, 415-442-75T5 EXT:
1 of

$$
3 \text { ORIOIN: JOPLIN }
$$

\section{WEI QHT: 15080 LENGTH, - UIDTH: LOABED DIMS - LENETH, - UIDTH: 1 of 1 COHYODTY DESCRIPTION DEATHEAD SPENT FUEL YRUCK/TEAK}

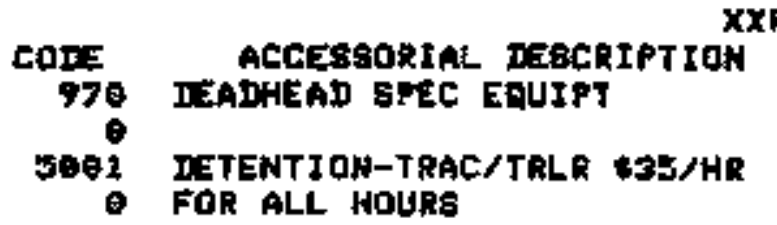

2 of

$$
3 \text { ORTEIN : CHARLESTON }
$$

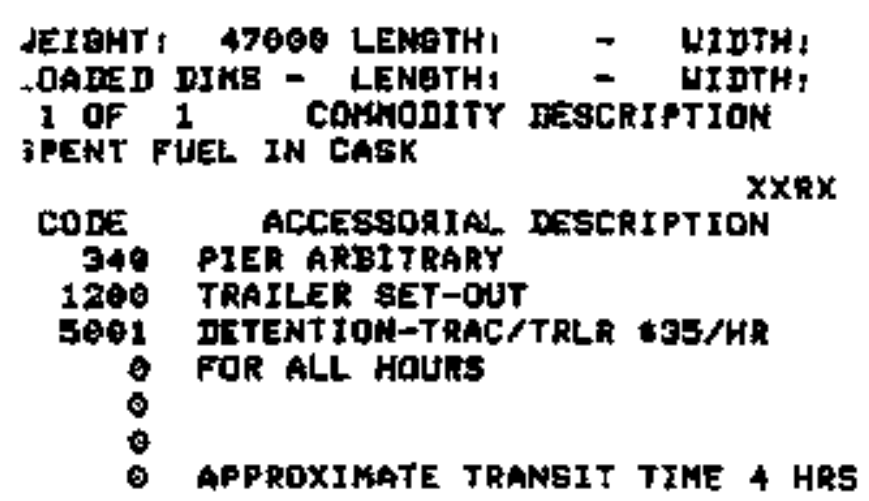

3 of 3 ORIGIN: DUNRARTON
GTATE: WO ZIP, gTATE: BE ZTP:

- HETOHT -

- HEIDNT: -

H/H EXT WEIEHT

EXT

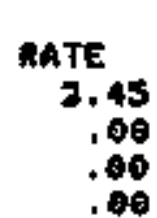

COMHODITY CHAREE

TDTAL CHAREEg
AHIPI $00 / 00 / 00$ KILES I 1003

TRAILER,

TARIFF, $1007 \mathrm{C}$

AATE

ChareE

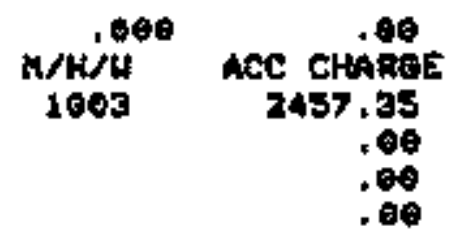

2457,35

2457.35

8TATE। GC ZIP! STATE, SC ZIPI

- HEISHT: DEIOHT: $\vec{T}$ M/H EXT UEIGHT $\begin{array}{cr}134 & F \\ \text { EXT } & \text { RATE } \\ X & .00 \\ X & .00 \\ & .00 \\ & .00 \\ & .00 \\ & .00\end{array}$ CoMkODITY CHAROE TUTAL CHAREES AHIP। $00 / 00 / 00$ MILES: 134

TRAILER I TARIFF; 4907C RATE

$3.139 \quad 1976.94$ M/HJW ALC CHARES 30.00 95.06 .$\theta 0$ .00 .60 $.0 \theta$ .00
2121.94 2121.94

STATE, SC ZIPI EHIP: $00 / 00 / 00$ 


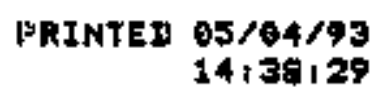

5001 DETENTION-TAAC/TRLR \$35/HR

- HEJOHT: - TRAILER:

- HEIGHT: - TARIFF, $4007 \mathrm{C}$ H/H EXT UEIEHT RATE CHAREE

$\begin{array}{rr}\operatorname{EXT}_{X} & \text { RATE } \\ & .00 \\ & .00\end{array}$

H.
HAO

50,00 .60 .00

\section{COMMODITY CHAREE $6 \$ 0.00$}

TOTAL CHAREES 650.00

เ** END OF QUOTE +4t 


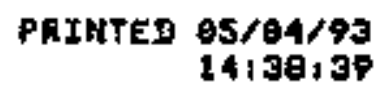

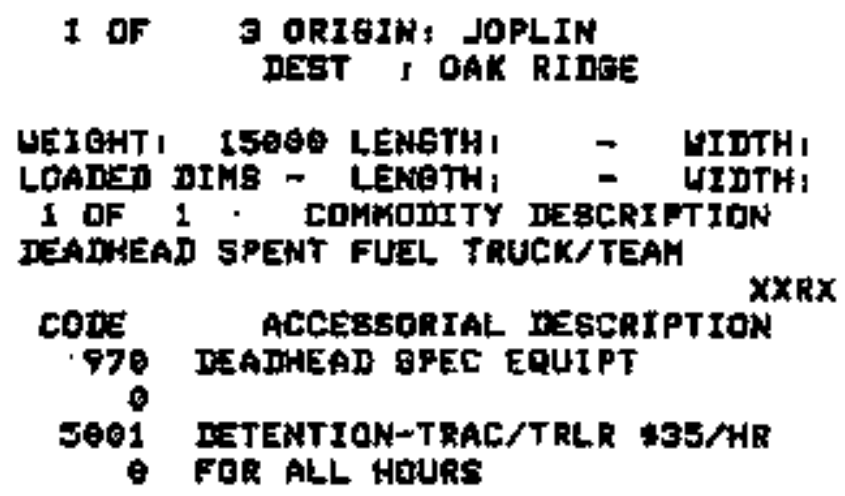
$x \times R X$

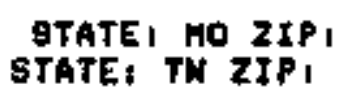

- HEIQHT: - HEIOHT, M/H EXT UEIEHT EXT RATE
2.45
.00
.00
.00 COMMODITY CHAREE TOTAL CHAREES

BHIP MILES I

TRAILER : TARIFF; $4007 \mathrm{C}$ RATE charee

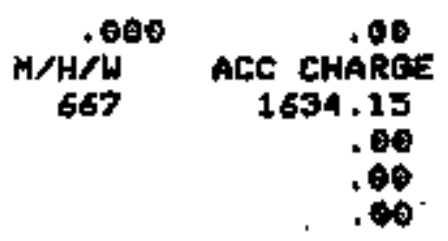
.00 CC CHARGE .00 $\theta$ .$\infty$ 1694,15 1634,25

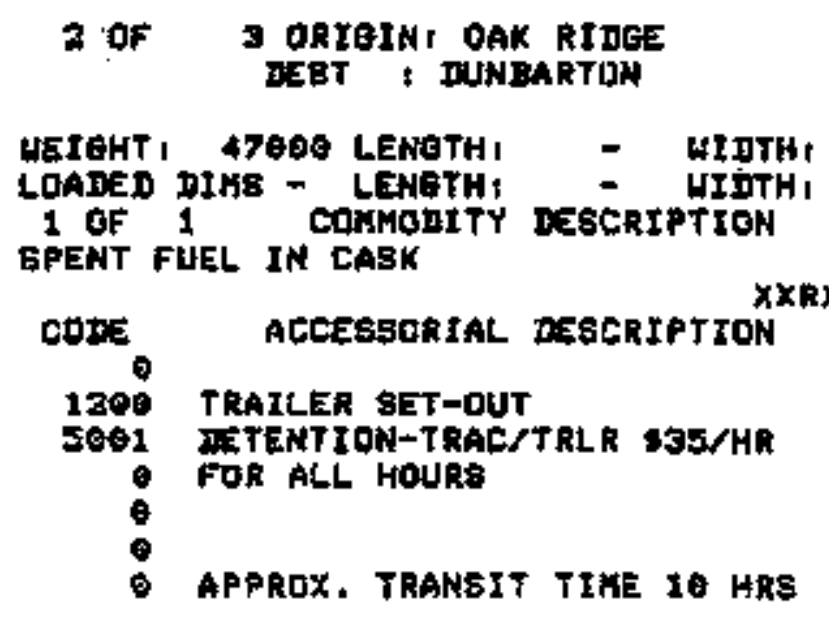

STATE! TN ZIP, STATE: GC ZIP!
- HEIEHT:
HAH EXT WEIOHT
H/H
359 F 47000
EXT RATE

$\mathbf{x}$

.60

$+\infty$
.00

.00

.06

.06

.00

COHMODITY CHAREE

TOTAL CHAREES
SHIPt $00 / 00 / 00$ HILES, 359
TRATLER:

TARIFF 1 4007C RATE

CHARES

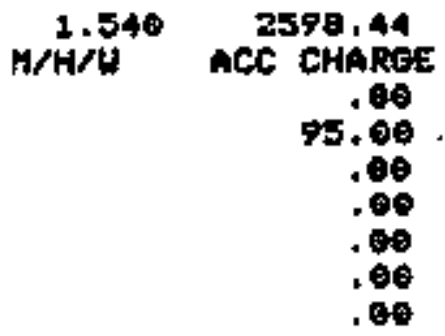

2693.44

2693.44

STATE, SC ZIP,

BHIP, $00 / 00 / 00$ 


$$
\begin{array}{r}
\text { PRINTED 05/04/93 } \\
14: 98140
\end{array}
$$

TRI-STATE MOTOR TRANEIT, CO. QUOTING SYSTEM - QUATE INQUIRY
DUZI006 PAGE

DUDTE NUHEER: 145033 ENTERED DY: GLH ENTEREDI 05/04/93 COMPLETEDI O0/00/00

$$
\text { DEST I DAK RIDOE }
$$

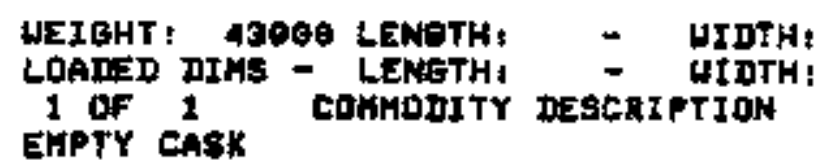

XXRX cons ๑ ACCESSORIAL DESCRIPTION Soe1
DETENTION-TRAC/TRLE \$35/HR STATE: TN ZIP:

MILES, 330
- HEICHT I H/H EXT WEIGHT
TAAILER ,

TARIFF! $1007 \mathrm{C}$ RATE CHARGE EXT 4 4N000 160 .00 .00 
PRINTED 05/04/93 $14,38,44$
TRI-STATE NOTOR TRANEIT, CO, QUOTINO SYRTEH - GUOTE INQUIRY
QuII006

PAEE
1

QUUTE NLWEER, 145068 ENTERED BY: SLK ENTEREDI $05 / 04 / 93$ COMPLETED: $0 \theta / 00 / 00$ CUST: NAME, MOARIGON-KMUDBEN

CITY: SAN FRANCISCQ, CA

ADDi FAX 415-447-7673

CONTACT: PHIL KELLEHEA DRTLTNATED,

PHONE, 415-442-7575 EXT:

2 DF J DRIBIN; EOPLIH DEST FORT HORTH
BTATE: MO 2IP: STATE, TX ZIP:
8HIP; $00 / 00100$

MILES, 371

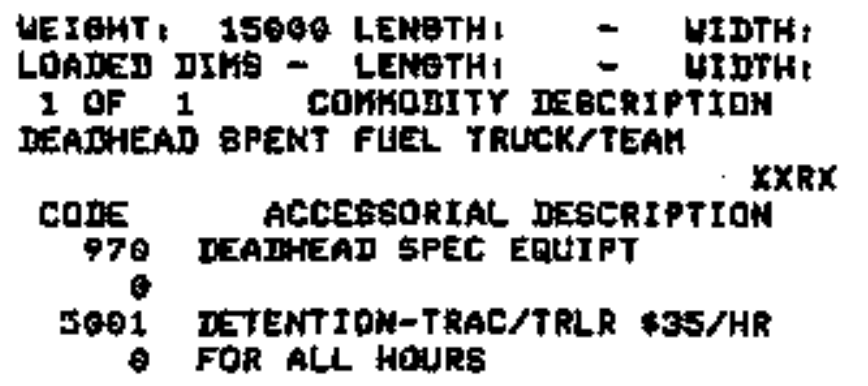

STATE: TX ZIP, 8TATE, TN 2IPI total CHAREES 908.95

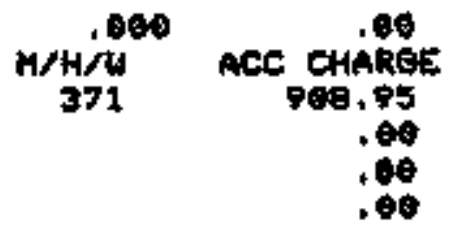

909.95

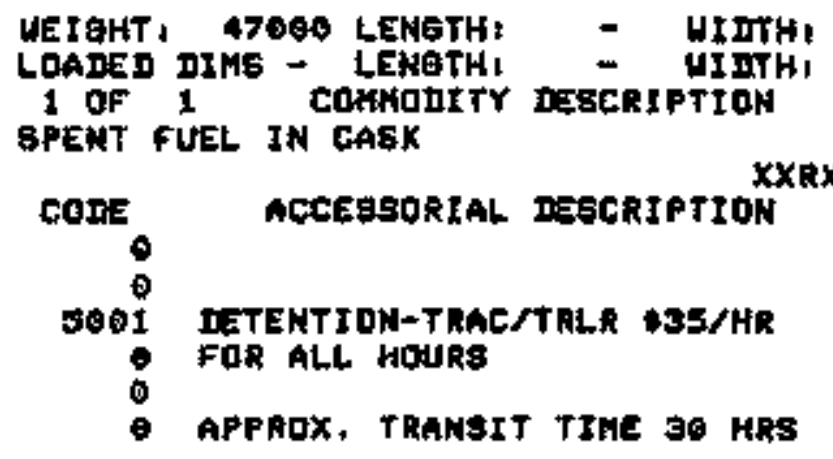
COMMODITY CHAREE $\quad 4743.64^{\circ}$
TUTAL CHARGES 4243.64


TRI-STATE MOTOR TRANEIT, CO, QLOTING QYSTEH - QLOTE INEUIRY
Qut 1006

PAEE

COAPLETED, $00 / 00 / 00$
ADDt fax $415-442=7673$

PHONE, 415-442-7575 EXT
1 QF

$$
3 \text { ORIGIM, SOFLIN }
$$

DEפT' FORT WORTH
BTATE, MO ZIP: GTATE, TX ZIPI
SHIP : $00 / 00 / 00$ HILES: 371

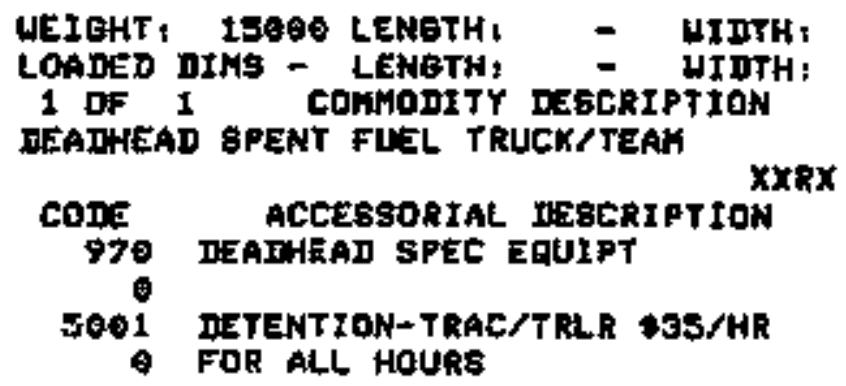

ACCEssortat Hesenipt XoN

$$
\begin{aligned}
& \text { HEIGHT: } \\
& \text { H/H EXT HEIGHT }
\end{aligned}
$$

TRAILEA,

TARIFF: $4007 \mathrm{C}$

RATE

CHAREE

$$
\begin{array}{rr}
\text { COHMDDITY CHAREE } & 908.95 \\
\text { TOTAL CHAROES } & 900.95
\end{array}
$$

\section{OF \\ 3 ORIEIN, FORT MORTH DEST I OAK RIDEE}

STATEI TX ZIP: STATE, TA ZIPI
- HEICHT: -

IM EXT UEIGHT
SHIP: $\theta 0 / 00 / 00$ MILES I 1089

\section{WEIEHT: 97000 LENGTH: - HIDTH: LOATED DIMS - LENETHI - UIDTH: SPENT FUEL IN CASK}

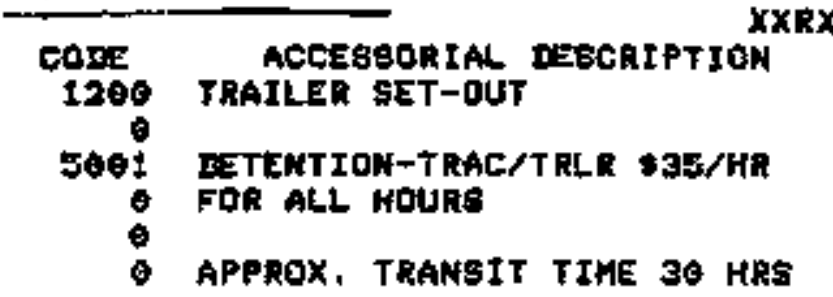

3 OF 3 ORIEIN, DAK RIDEE
BEST I FT UORTH

STATE, TN $25 \%$ BTATE: TX ZTP:
SHTP: $00 / 00 / 00$ HILES, 847
TRAILER,

TARIFF, AOOTC

RATE

CHAREE

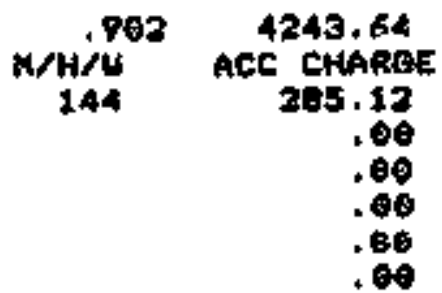


COMHAND: Q E:

RUI TOO1

QUUTE NUMBER + 1.43B39

DUOTING \$YETEK - QUOTE INQUTRY

EATERED BY: \$LH

cust :

NAME: MORRI GON-KNUDSEN

ADD: FAX 415-442-7673

CITY: SAN FPANCISCD

STATE! CA ZIP:

PHaNE: 4154427390 EXT:

CONTACT, DAWID BURTON

ORIGXNATEO AY:

SHJF DATE:

3 OF 6 DRIBIN: DUNBARTON DEST : NU TS
STATE: SE ZIP,

STATE: NV ZIP:

MYLS: 2495

HORE? M N

2)

ATOPS ; 13

WEIGHT: 49000 LENGTH: - WTOTH

LOADEO OIHS - LEMGTH: - WTOTH:

1 DF 1 COMMODITY DESCRIPTION

XXRX 2495

COOE

ACCESSORIAL DESCRIPT ION

970 DEADHEAD SPEC EQUIFT

SPENT FIJEL TEAH FROH JGPLIN, MO

G102 SPENT FUEL SECUR PRU

1200 TRAILER SET-DUT

905 PERMIT/TAX/FEE/NOTIF

F001 DETENTION-TRAC/TRLR T35/HR

$\$ 002$ OETENTION-TRL, ONLY \$SO/DAY n

EXT RATE

16

3.450

0.450

1.980

$x$

1.980

HEIGHT

TRATLER :

TARIFF: 40075 24000

RATE

CHARGE

24950

$+11$

913.78

50.00 


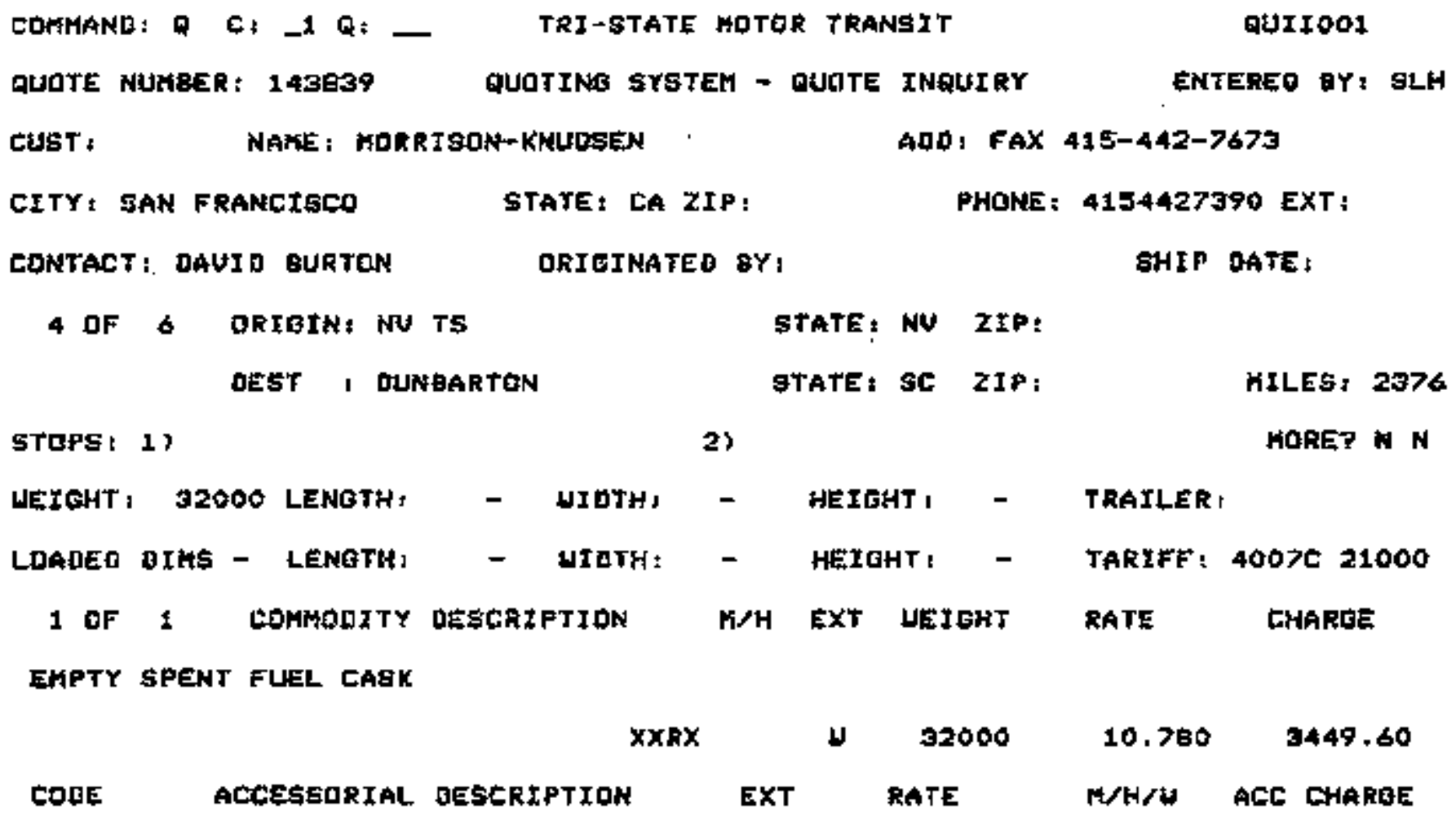




\section{Appendix D-2}

Nuclear Assurance Corporation-Cask Rates and Specifications 
Nuelear A5surance Corporation 655 Eng ineerıng Drize

Mr. David Burton

Morrison Knudsen

180 Howard Street

San Francisco, CA 94105

Dear Mr. Burton:

In response to our teleconference today, I an enclosing a specification sheet and photograph of each of Nuclear Assurance Corporation's (NAC) transport cask types. Also enclosed is a standard lease rate sheet applicable for the casks. Please note that the lease rate varies significantly with the period of the lease. In addition, labor for any required lease is separate above the base lease period and cost.

As I cautioned you in our discussion, assessing the relative value of leasing versus purchasing a cask requires defining several details of the planned use. Thus the enclosed information needs to be used carefully for such evaluations. NAC would be pleased to perform such an evaluation if needed. Please call if you need further information.

Sincerely,

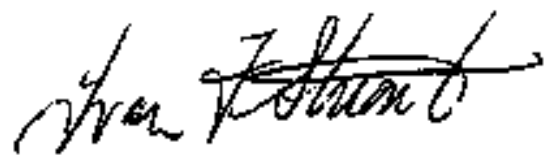

Ivan F. Stuart

Vice President

Engineering Design Services

IFS:sb

enclosure:

$$
\text { Gaces; } 7, \sec x
$$




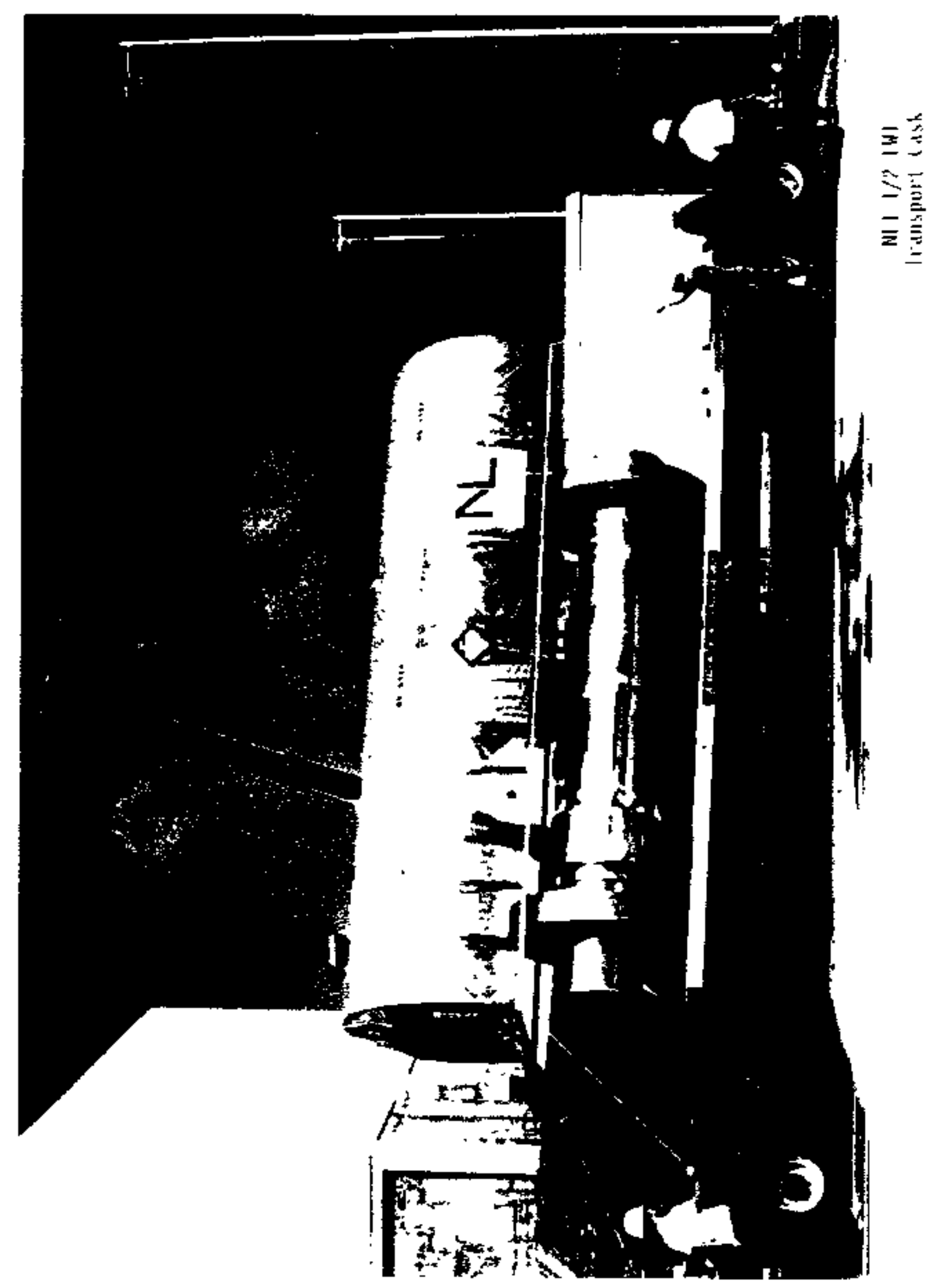




\section{NUCLEAR ASSURANCE CORPORATION}

\section{Standard Commercial Policy for Lepal Weight Truck Cask Leasing}

Base Price

$\$ 60,000$

The base price is for a single, continuous cask lease period of not more than $\mathbf{1 0}$ days. Additional days of cask lease will be at the following rates:

Days 11 through 30

Days 31 through 90

Days 91 through 180

Days 181 through 360
$\$ 3,500 /$ day

$\$ 3,000 /$ day

$\$ 2,500 /$ day

$\$ 1,800 /$ day

Included in the base price are four days of labor for site assistance: two days at the shipment origination facility and two at the shipment destination facility.

\section{Additional Equipment and Services}

NAC will provide additional equipment and services to support the cask lease. In general, expenses will be invoiced at cost plus 15 percent and labor will be invoiced at the following rates:

Officer

Senior Manager/Engineer

Manager/Engineer

Associate Engineer/Designer

Secretary/Clerk
$\$ 220$ hour

$\$ 150 /$ hour

$\$ 130 /$ hour

$\$ 85 /$ hour

$\$$ \$0/hour

Additional equipment and services include the following:

- Special equipment design and fabrication

- Cask and related equipment transportation

- NAC reviews and licensing

- Cask interrals (basket) change-out

- Neutron shield tank filling and draining

- Preliminary site visits and interface assessments

- Additional site assistance, site visits and meetings

- Travel and subsistence costs

- Schecule changes

- Shipment notifications and escort arrangements

- Route approvals and special permits

- Shipper and consignee support and coordination

- IAEA endorsements

- Other services as requested 


\section{$\underline{\text { NLI-1/2 }}$}

Owner

Type

Manufacturer/Vendor

Capacity

Intact Speot Fuel Assembilies

Cans Consolidated Fuel Rods

Other Configutration

Weight (tons)

Loeded

Empty

Design Heat Rejoction (kW)

Shape

Dimensions

Overall Length (in)

Overall Diameter (in)

Cavily Length (in)

Cavily Diameter (in)

Inoer Shell Wall Thickness (in)

Depleted U Wall Thickness (in)

Lead Shield Wall Thickness (in)

Outer Sbell Wall Thickeness (in)

Neutron Shield Tank Thickness (in)

Inner Container Wall Thickoess (in)

Materials of Construction

Cask Body

Neutron Shield

Sides

End

Basket.

Cavity Atmosphere

Operatiog Temperature ( $\left.{ }^{\circ} \mathrm{F}\right)$

Operating Pressure (psig)

Ontside Surface Dose (mrem/hr)
Nuclear Assurance Corporation

Legal Weight Truck Shipping Cask

NL Industries Inc.

I PWR: 2 BWR

2 PWR; 4 BWR

Metallic Fue!

23.1

223

10.6

Cytindrical

195.25

47.125

178

13.375

0.5

2.75

2.125

0.875

525

0.25

SSDepleted U/LeadisS

Water \& Ethylene Glycol

None

$S S$ and Alaminum

He, Air if heat is less than $2.5 \mathrm{~kW}$

1010 (maximum fuel cladding temperature)

117 (moximum)

53 (marimum)

Liceasing Status - Initially licensed by the USNRC in 1974; can be used to stip either intact or consotidated LWR foel.

Comments - Cests heve separate beskets for PWR and BWR fuel. There are five casks currently in existence. 


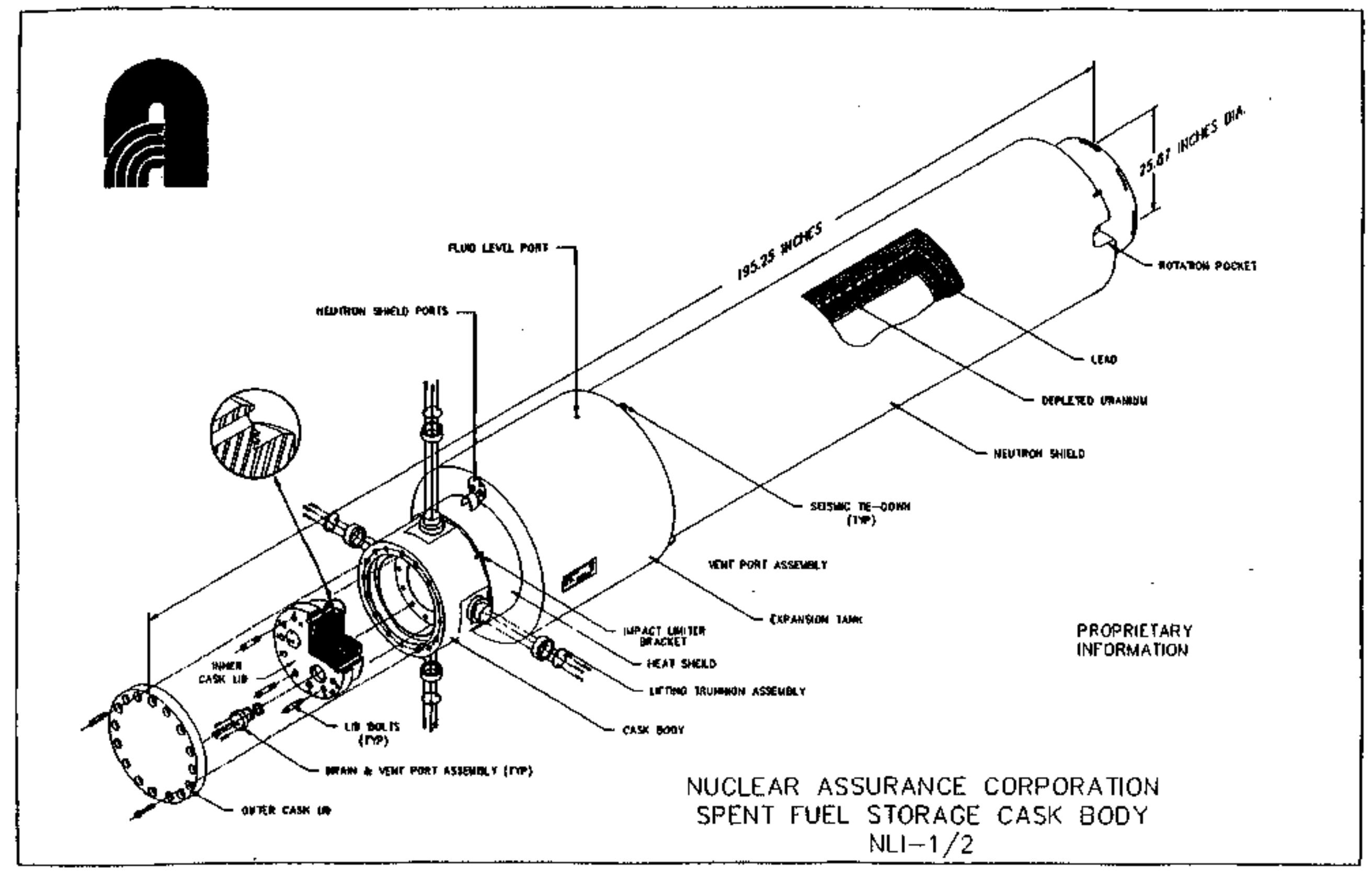




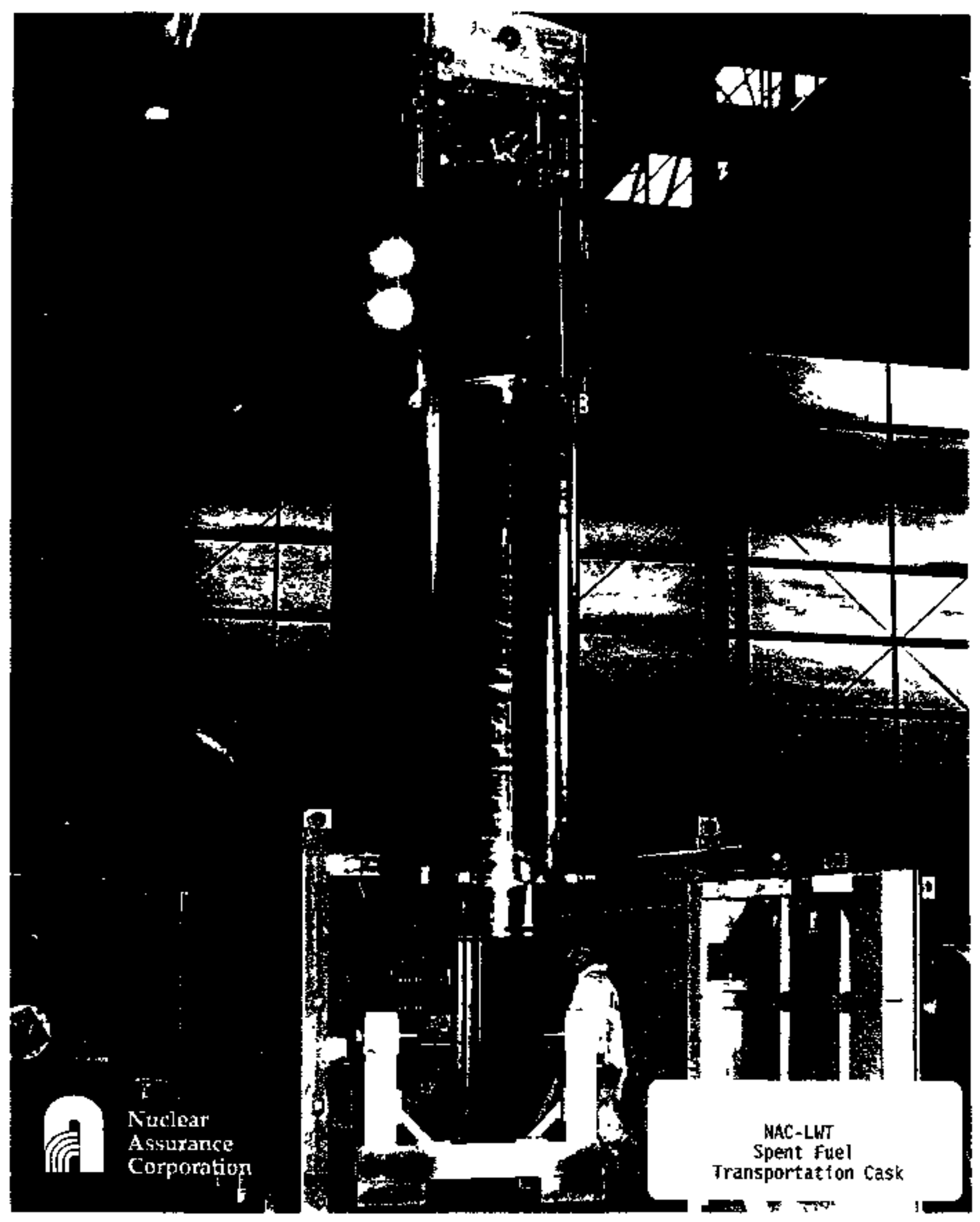




\section{$\underline{\text { NAC-LWT }}$}

Designer

Trpe

Cupacity

Intect Spent Ful Assemblies

Other Configurations

Weing (toos)

Louded

Empry

Derion Hear Reiection (kW)

Shrose

Dimertions

Overill Length (in)

Overall Diameter (in)

Crviny Length (iv)

Cirity Dianexer (iv)

It mer Stell Wall Thickoss (in)

Ledd Stield Wall Thickness (in)

Outos Sholl Well Thickeess (in)

Nextron shicid Tank Thiekness (in)

Netursos shield Wall Thiteness (in)

Materials of Construction

Cask Body

Netroes Shield

Sides

End

Busket

\section{Cooling Fins}

Cuivs Amosphere

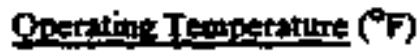

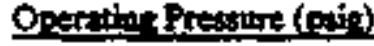

Outeide Sinflec Dowe (mrem/hr)
Nuclesr Ausurance Corporation

Lepal Weight Truck Stipping Cuk

1 PWR; 2 BWR (3.7 w/0; 40 w/o enrichment) 15 Metallic Fuel Rods

25.6

24.0

25

Cyotindrien

199.80

442

18090

13.375

0.75

5.75

120

5.00

0.25

SSLeadSS

Water \& Ethylepe Glyeol (10 w/o Boron)

None

Alumimum

None

Air or lever Gas

209 (ksk rodial turtace; maximum)

0

100 (maximum)

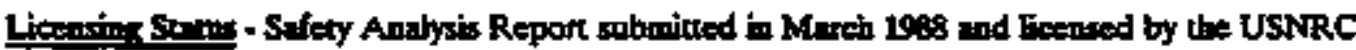
Decentiner 61 1909.

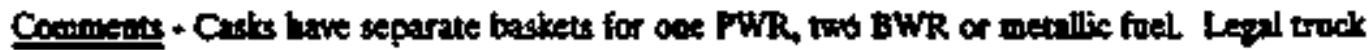

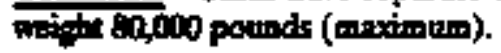




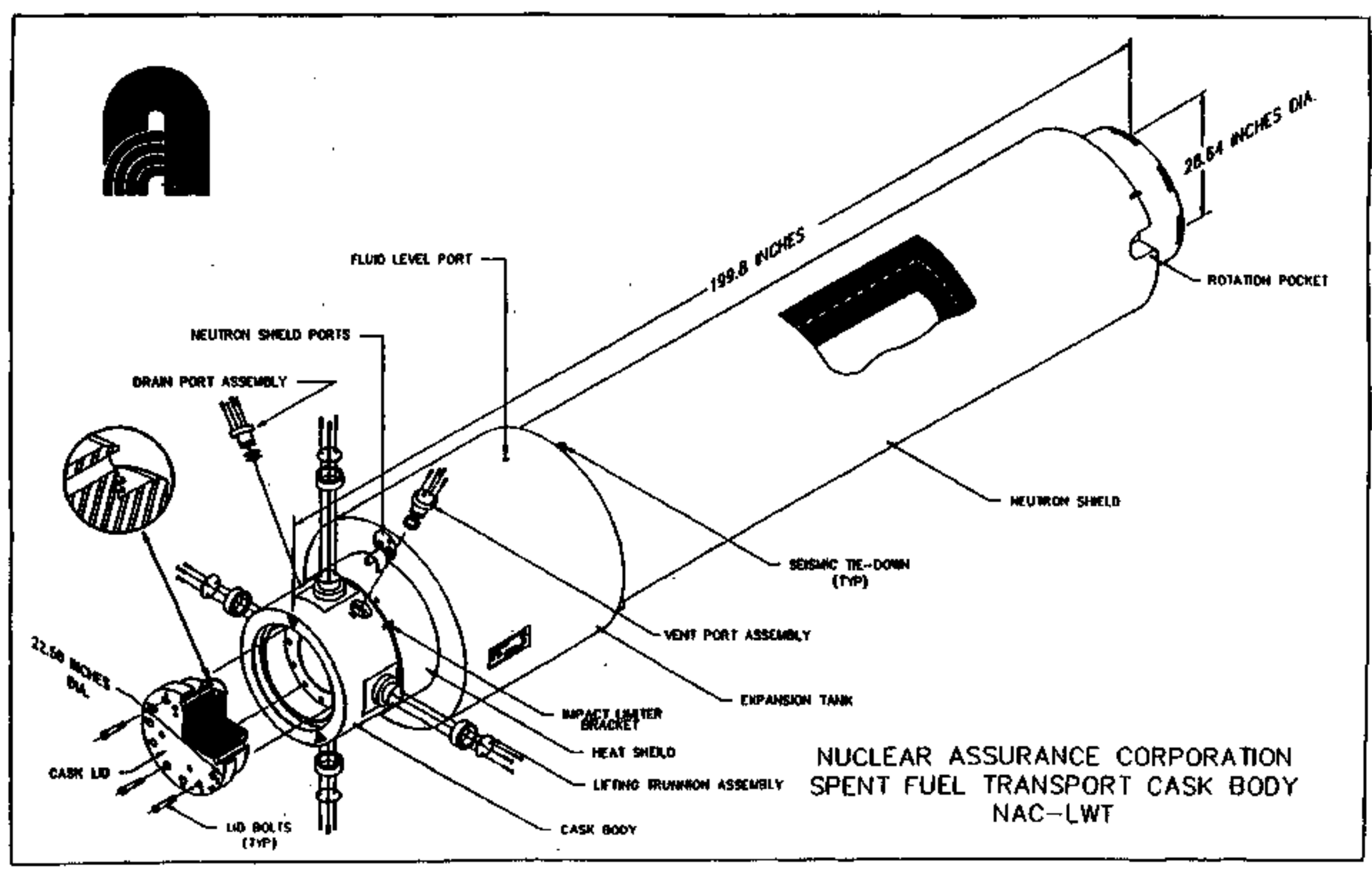




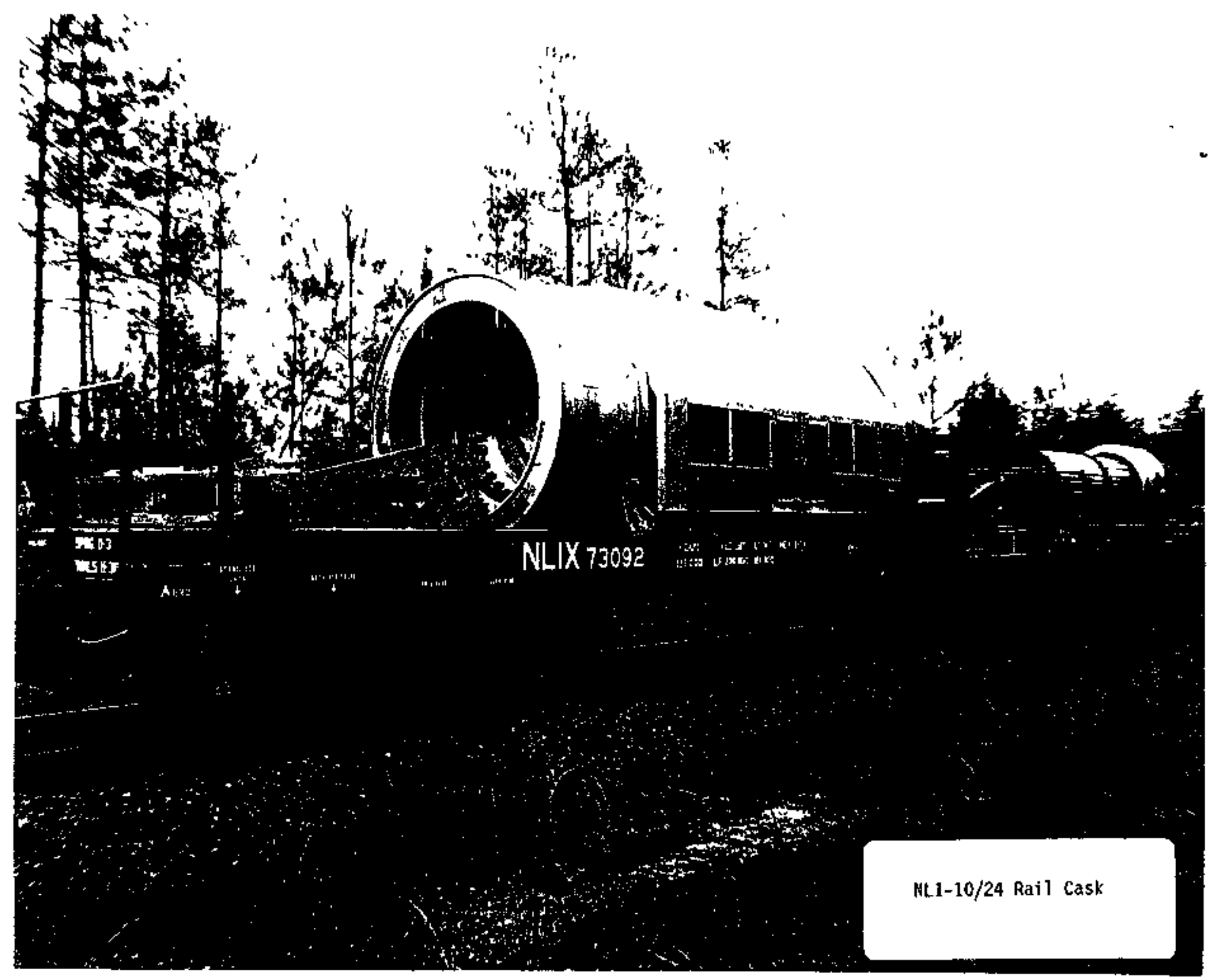




\section{NLI-10/24}

Ouner

Type

Manufactarer/Vondor

Caparity

Intact \$pent Fuel Assemblies

Weight (tons)

Londed

Empty

Design Heat Retection (kW)

Shape

Dimensions

Overail Length (in)

Overall Diameter (im)

Cavity Length (in)

Cavity Diameter (in)

Inner Shell Thickness (in)

Outer Sheil Thìkness (ii)

Lead Shield Wall Thickness (in)

Neutron Shield Tank Thickness (ii)

Outer Closure Head Thickness (in)

Materials of Constrnction

Cask Body

Nestron Shield

Sides

Ends \& Strategic Wall Locations

Basket

Cooling Fins

Dry Shipment

Atmosphere

Cavity Pressure (psig)
Nudear Assurance Corporation

Rail Shippirg Cask

NL. Indostries Ine.

$10 \mathrm{PWTR} 24 \mathrm{BWR}$

965

89

70

Cytindrical

204.5

88

179.5

45

0.75

2

6

9.75

2.5

\section{SSILadSS}

Water

Ricorad

Ahuminum-bined with Ag-In-Cd plates in SS

Concentric (forced water circulation

cooling from separate cooling circuit)

He

23.1 (normai); 500 (maximum.)

Noxmal Operating Temperatures

(with only one of two cooling systems operative)

Outer Sarface ("F)

227

Inner Seal ( $\mathrm{F})$

268

Bastex ("F)

451 (maximum)

Fuel Assembly ("F)

690 (atverage)

Outside Surface Dose (mrem/hr)

200 (maximum)

Licensing Stames - Licensed by the USNRC for shipment using Ag-In-Ca basket.

Commonts - Cask has two separate baskets-cae for PWR and one for BWR. Due to no demand for the use of this cask, previous owner recovered silver frotn the baskets in the late $1970 \mathrm{~s}$, thus, no baskets exist for the cask at present. There are two casks currently in existence. 


\section{IIL 10/24 PAIL CASK}
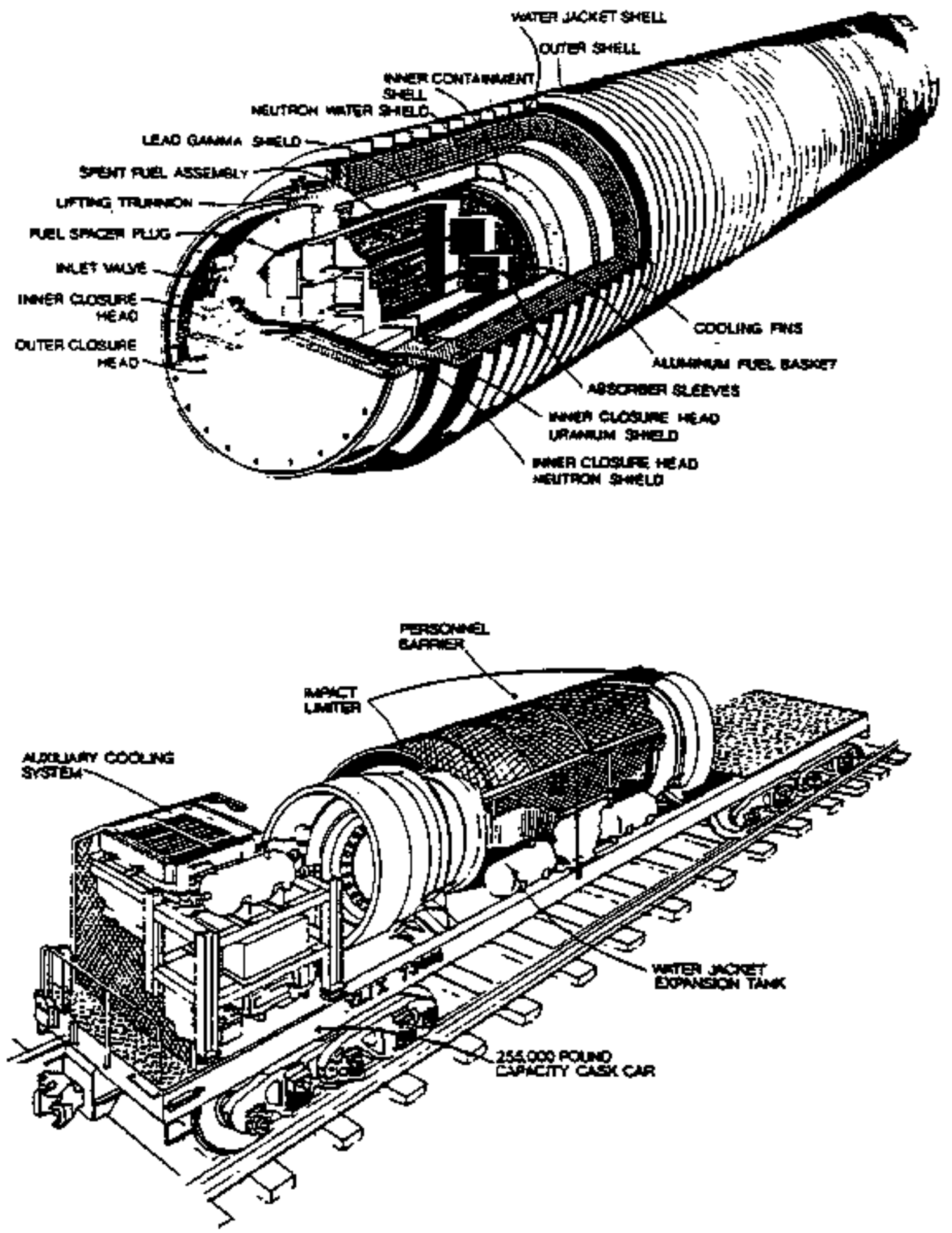
Appendix D-3

General Atomics_Cask Rates and Speciflcations 
NWM:RMG:198:93

File 6.25.3

April 27, 1993

Mr. David Burton

Morrison-Knudsen Corp.

180 Howard

Sam Francisco, CA 94105

Dear Mr. Birton:

Please find enclosed the information you requested concerning the use of GA's FSV-1 Cask.

If you have any questions or if I car be of any assistance, please don't hesitate to call me at 619-455-2583 (FAX 619-455-2596).

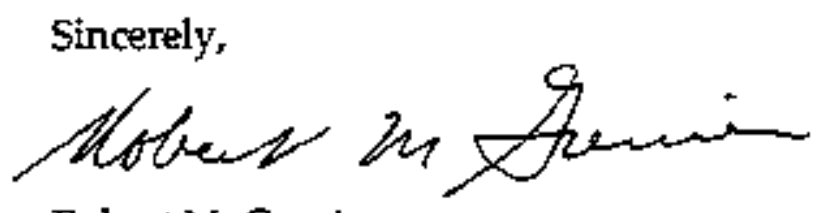

Robert M. Grenier

Director

Nuclear Waste Management Division

$\mathrm{RMG} / \mathrm{j}$

Enclosure

cC: D. Rickard 


\section{INFORMATION REQUEST \\ TO \\ MORRISON KNUDSEN CORP. \\ April 27, 1993}

FSV-1 CASK

Dally Rent *

Transportation

$\$ 1,200 /$ Day

Burlal Liners

Actual Costs Plus 15\%

$\$ 8,000$ / Each

\section{LABOR RATES}

Staff Engineer

Senior Englneer

Engineer

TechnIcian

$\$ 110 /$ Hour
$\$ 90 /$ Hour
$\$ 78 /$ Hour
$\$ 68 /$ Hour

PER DIEM

DOE Allowables

* Minimum rent duration is $\mathbf{3 0}$ days; includes all calendar days including shipping time; includes lifting yoke.

BURIAL LINER VOLUME

26 Ft 3

MAX ALlowable CONTENTS WEIGHT

3720 Lbs

(Includes 750 lbs weight of burlal liner) 


\section{BWR CONTROL ROD AND IRRADIATED HARDWARE DISPOSAL}

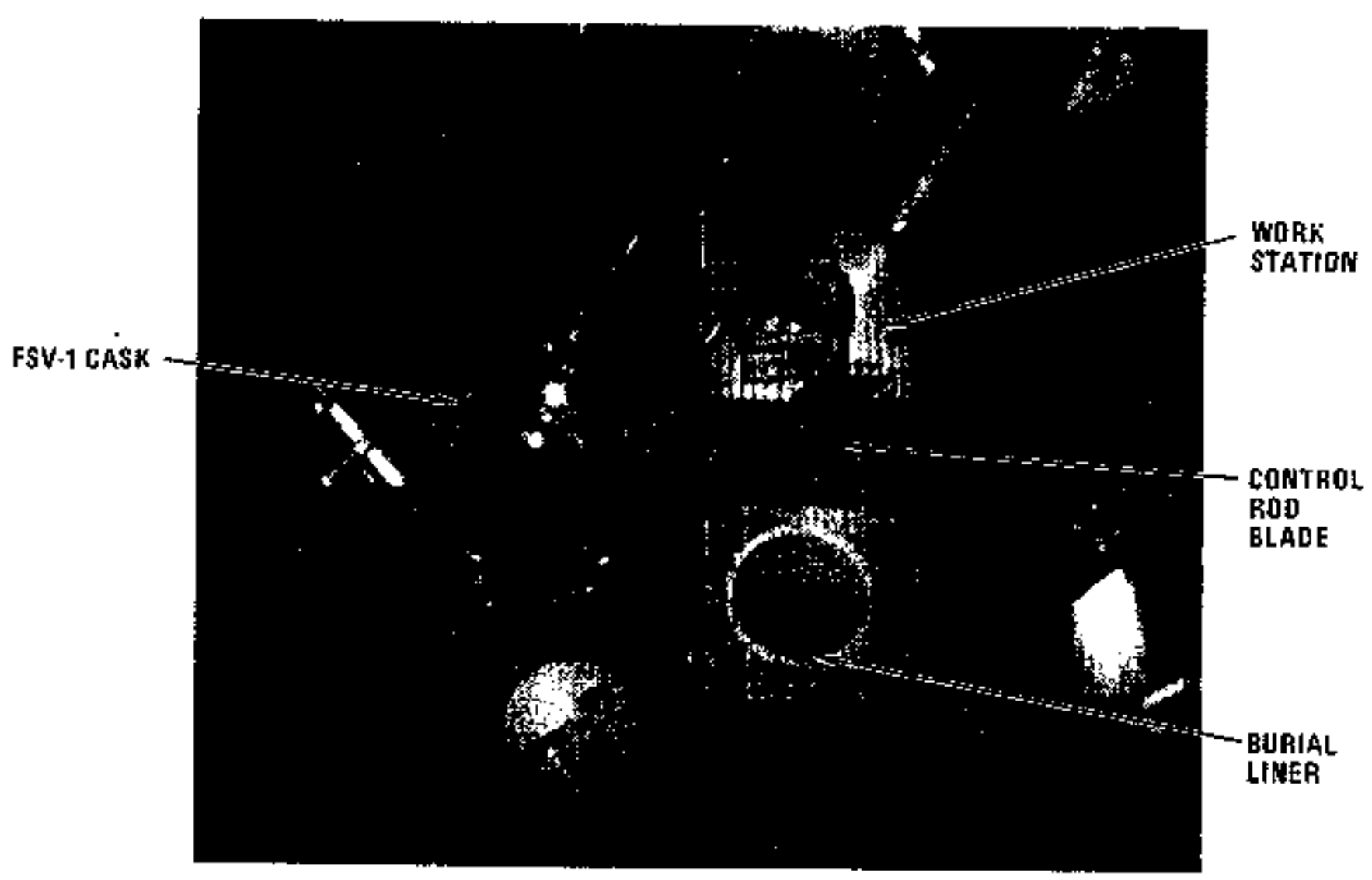

In 1983, GA became the first to successfully dispose of irradiated BWR control rad biades when the first nine shipments were made front the Monticelio nuclear plant in Mirnesota. Since then, GA has shipped about 400 control rod blades from seven different BWR plants-

GA's Model FSV-] cask can carry 4 intact BWR control rod blades. Additionally, in response to the high cost of burial, GA has developed a compaction system that increases the cask capacity to up to I2 control rod blades. GA's volume reduction equipment uses shears and a compactor, and unlike systems that use saws, GA's equipment does not generate chips and debris.

\section{GENERAL ATOMIES}




\section{EXPERIENCED AND RELIABLE}

GA provides a full range of BWR control rod and irradiated hardware disposal services, from simple cask and equipment leasing to managing and staffing operations from start to finish. Our personnel will:

- provide utility liaison to ensure proper matchup with utitity handling equipment and procedures

- train utility personnel on site

- provide fajej pool operations manpower

- perform radwaste survey and analysis

- optimize packaging to minimize burial costs.

\section{CA'S RCUIPMENT IS TALLORED TO UTILITIES' NEEDS}

In-Pool Work Station

\section{Control Rod Corner Shear}

Cantrol Rod Inverter, Reach

Tool, and Grapple Tool

Mobjle and Stationary LPRM Cutters and LPRM Grapples

Control Rod Velocity Limiter

Shear

Control Rod Compactor'
When suspended from the curb of the fuel pool, holds the control rod blade, FSV-l butial liner, and receiving container for stellite balls and axies.

Removes stellite balts and axles.

Provides efficient means for handling control tod blades.

Simplifies preparation and handing of LPRMs.

Removes velocity limiters prior to blade compaction.

Flattens the cruciform cross-section of the contral rod blade to 1 in. thickness. Triptes the capacity of the FSV-1 burial liner.

GA augments its BWR control rod and jradiated hardware disposal equipment with miscellaneous handling tools, fixtures, and underwater vacuuming systems. 


\section{MODEL FSV-1 CASK}

GA designed, procured, and now operates the FSt'- I casks. GA has used the FSV-1 cusks to ship control rod blades and contaminated hardware from utilities around the country to a burial site in South Carolina. Utilitios prefer the FSV-I because of its simple design and ease of handing. Repeated use in fuel pools has demonstrated that the smooth, stainless steel walts and uncluticred exterior of the cask minimize contaniination and simptify cask clean-up. In addition, the ample length of the internal cavity allows shipments of BWR control rod biades with minimal preparation. Shipments in the FSV -1 are legal weight, thus, avoiding the restrictions and limitacions associaled with overweight radjoactive shipments.

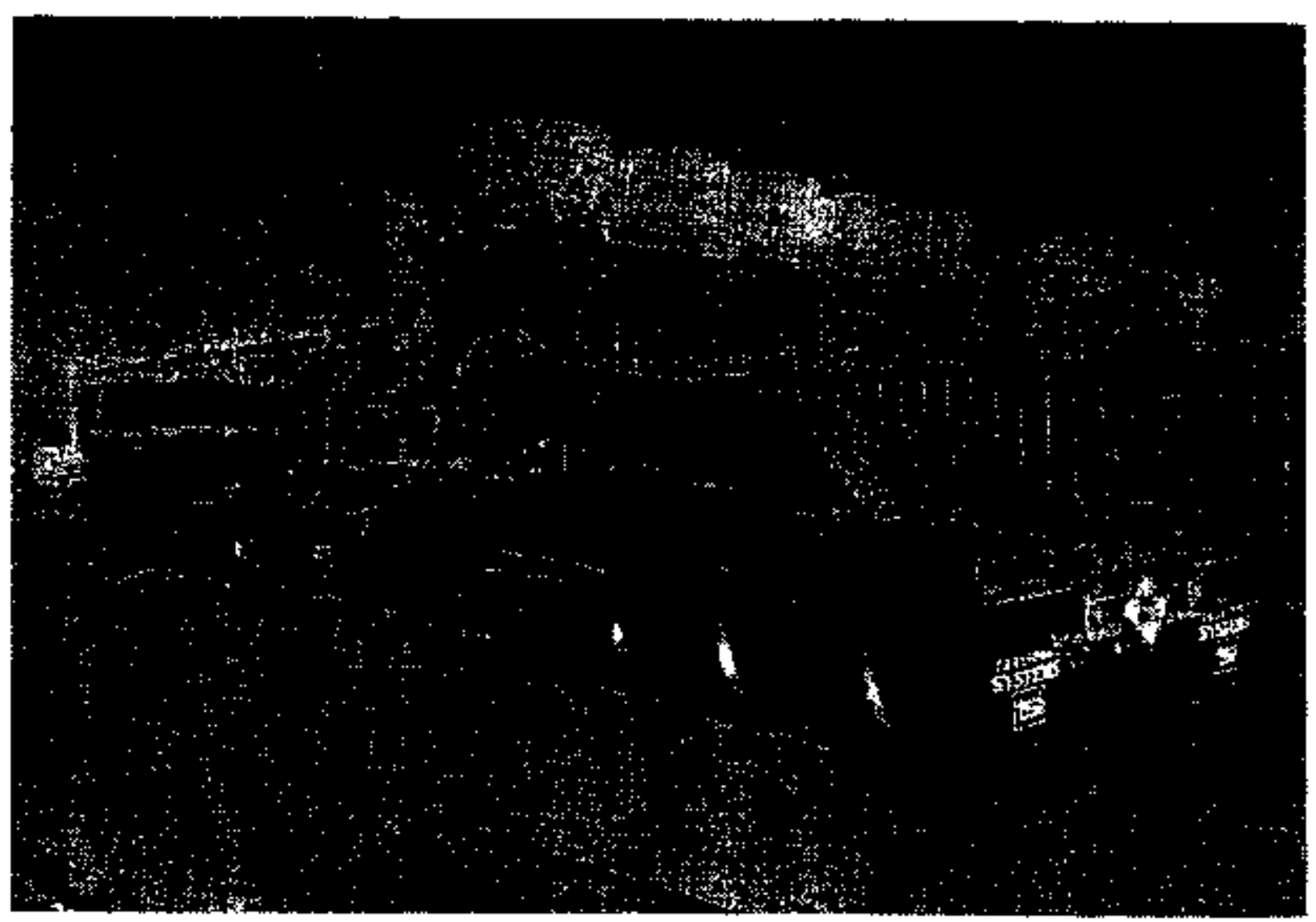




\section{MODEL FSV-1 TRANSPORTATION SYSTEM}

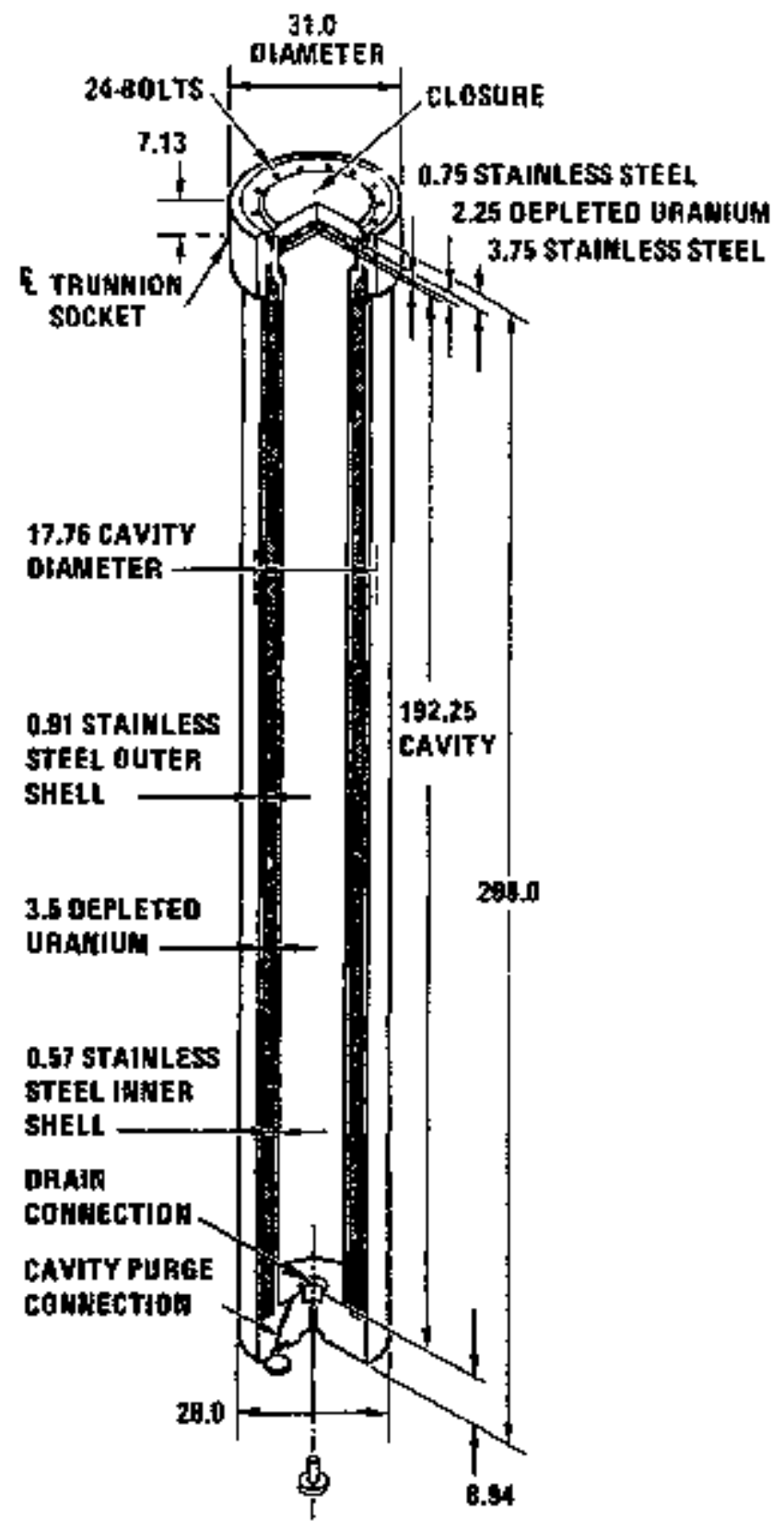

\section{FSV-1 SPECIFICATIONS}

Cask

Type B, NRC Certificate of Compliance No. 6346, Revision 16

Authorized Irradiated HTGR fuel and Contents irradiated and contaminated haroware

Primary Shieiding Depleted uranium encased in stainless steel

Cask Weight

42,300 Ibs, empty

Maximum Contents

3700 los

Weight

Thermai Rating

$4.1 \mathrm{~kW}$

\section{TRAILERS}

The FSV-1 casks are shipped on dedicated legal weight trailer's sitted with tiedown and handling equipment. The rear tiedown pivots for vertical loading and off-loading of the cask from the trajier. The fropt tiedown clamps the cask against a cradie. The trailers are available with and without personnel barriers. Each trajler wejghs 9,100 lbs.

\section{cask handLINo}

The FSV-I cask lifting system consists of a (1) lifting yoke which engages two trunnion sockets in the upper cask body and (2) a redundant lifting system mounted to the cask at the upper collar.

The lifting yoke is remotely operated using a water actuated hydraulic cylinder. The design is inherently fail-safe since the yoke arms are forced together by the weight of the cask, independent of the action of the operating cylinder. 

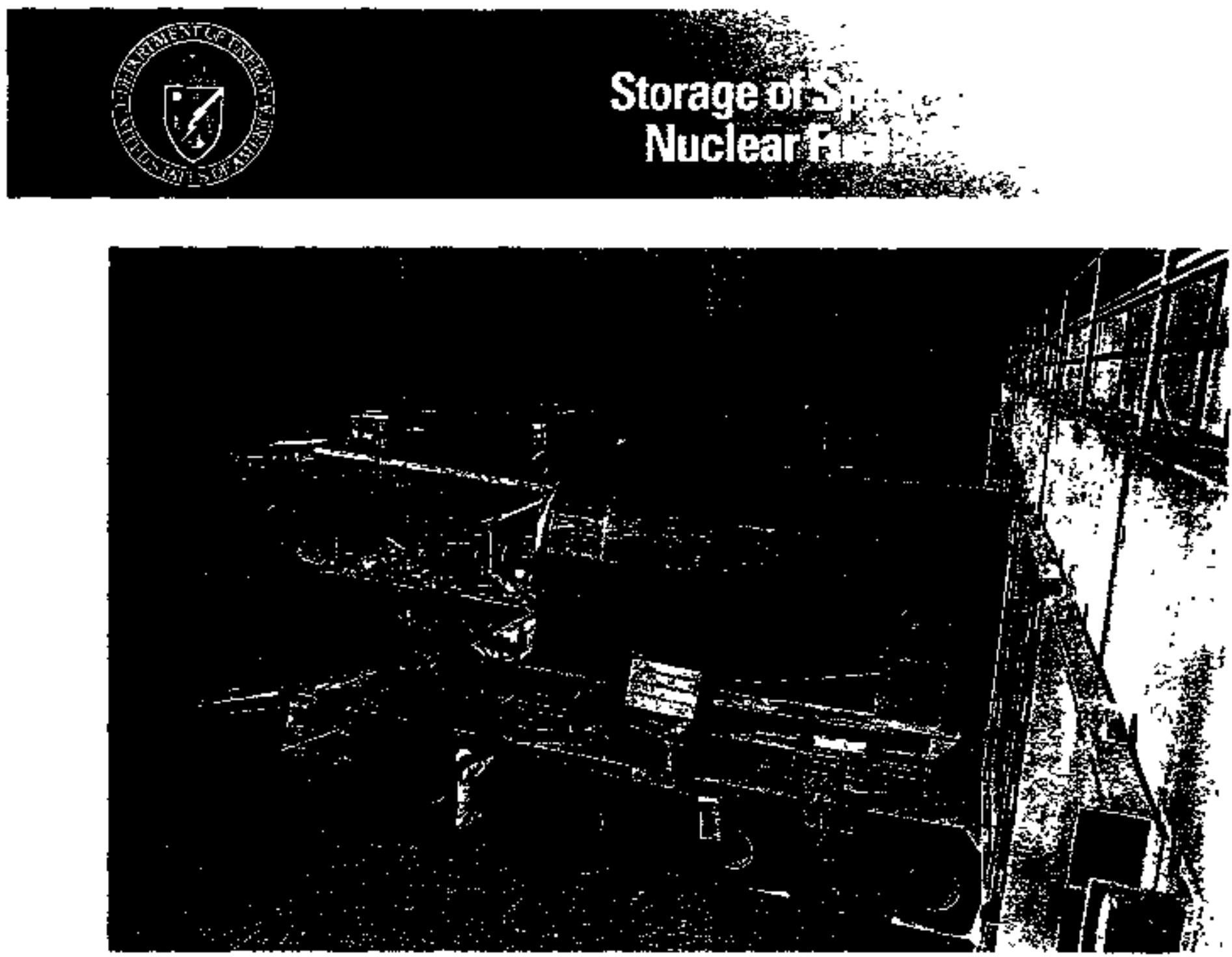

Loading of spent nuclear fuel into a concrete storage module front shitelded ounsfer cask at Duke Power's dry starage facillity.

Nuciear waste is material that either contains a radioactive substance or has been contaninated by radioactive eiements and is no longer useful. It includes waste products from nuclear processes, strch as mining uranium ore, fissioning of tranivitr in cotsmercial nuclear power plants, processing defense materials, and preparing nuclear isotopes for use in medical apptications. It also includes used protectuve clothing and containers that orxe held nuclear material.

In 1983 Congress enacted the Nuclear Waste Policy Acf (NWPA), which outtines a comprehersive plan for the safe disposal of spent nuclear fuel and other forms of high-level nuclear waste. It also includes development of a mined, geologic repository for long1erria disposal of all forms of highlevel radioactive wastes. An anendment enacted in 1987 authorkzs the development of a temporary, abovs:ground storage facilty called a Monitored Retrievabte Storage (MRS) facility. The MRS will store a lunited amount of "spent" of "used" tucleat fuel from commercial nuctear power plants, a solid forn of radioactive waste.

To produce electricity, nuclear power plants use solid, ceramic fuel pellets raade of uranium. Tremendous amounts of energy are stored in the centers of uranium atoms. When these atoms split, highly radroactive fission products are generyated along with the large amounts of heat that make steam to turn turtine generators. The rockhard fuel pellets are encased in strong metal rods. After turee or four yeurs in an operating ruclear reactor, the enengy remaining inside the pellets is no longer efficient enough to proxtuce usable heat and the pellets have becorne highly radionctive. These pellets and the surrounding rods must be isolated from the human environnent for Jong periods of time, on the order of thoustands of years. Until a permanent repository is in operation, spert fuel will continue to be stored in above-ground facilities such as the ones shown. The MRS witl build upon 


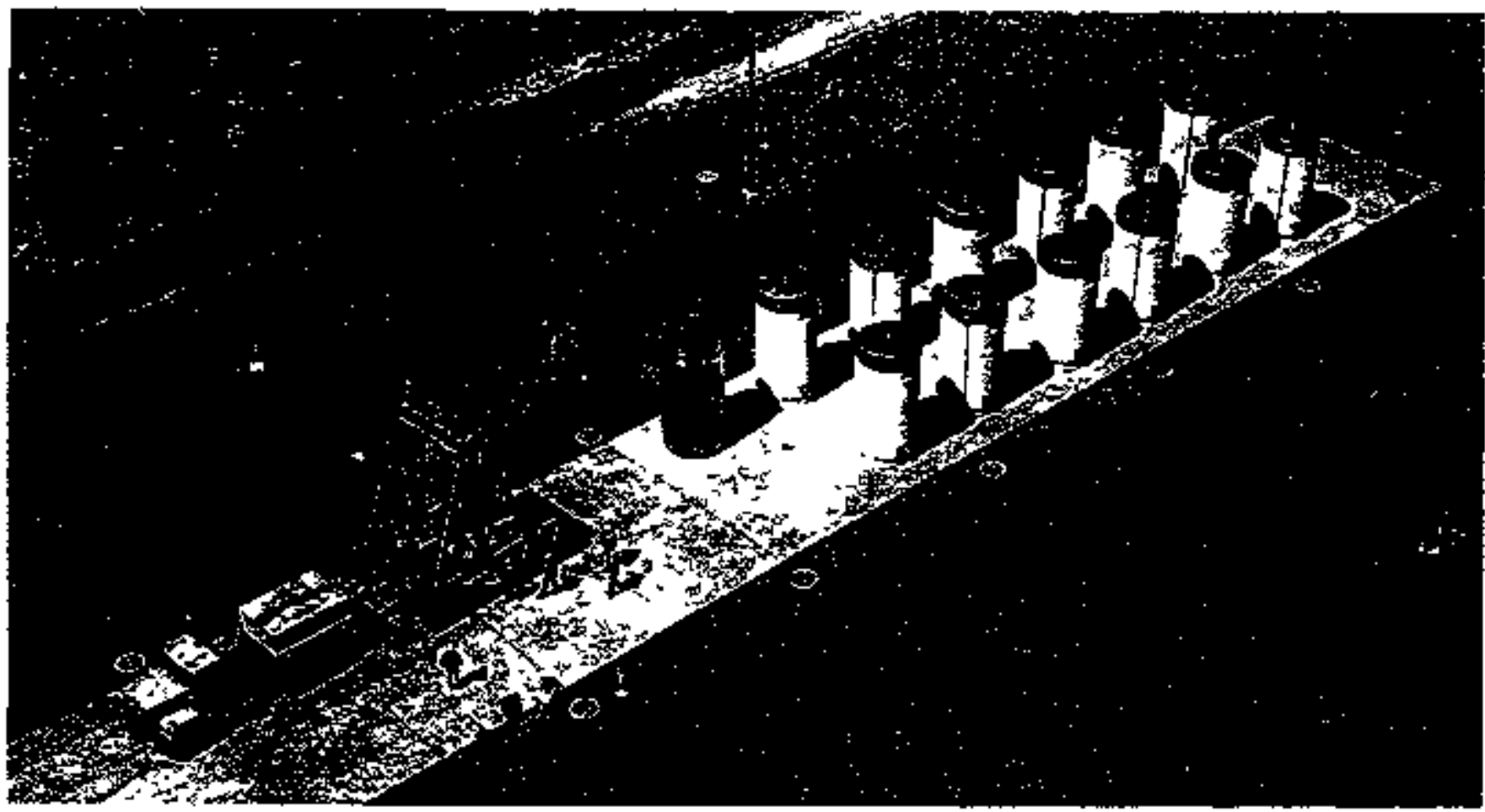

Storage of spent nuclear fuel in metal storage contaituers af Vinginia Power's dy storage facility.

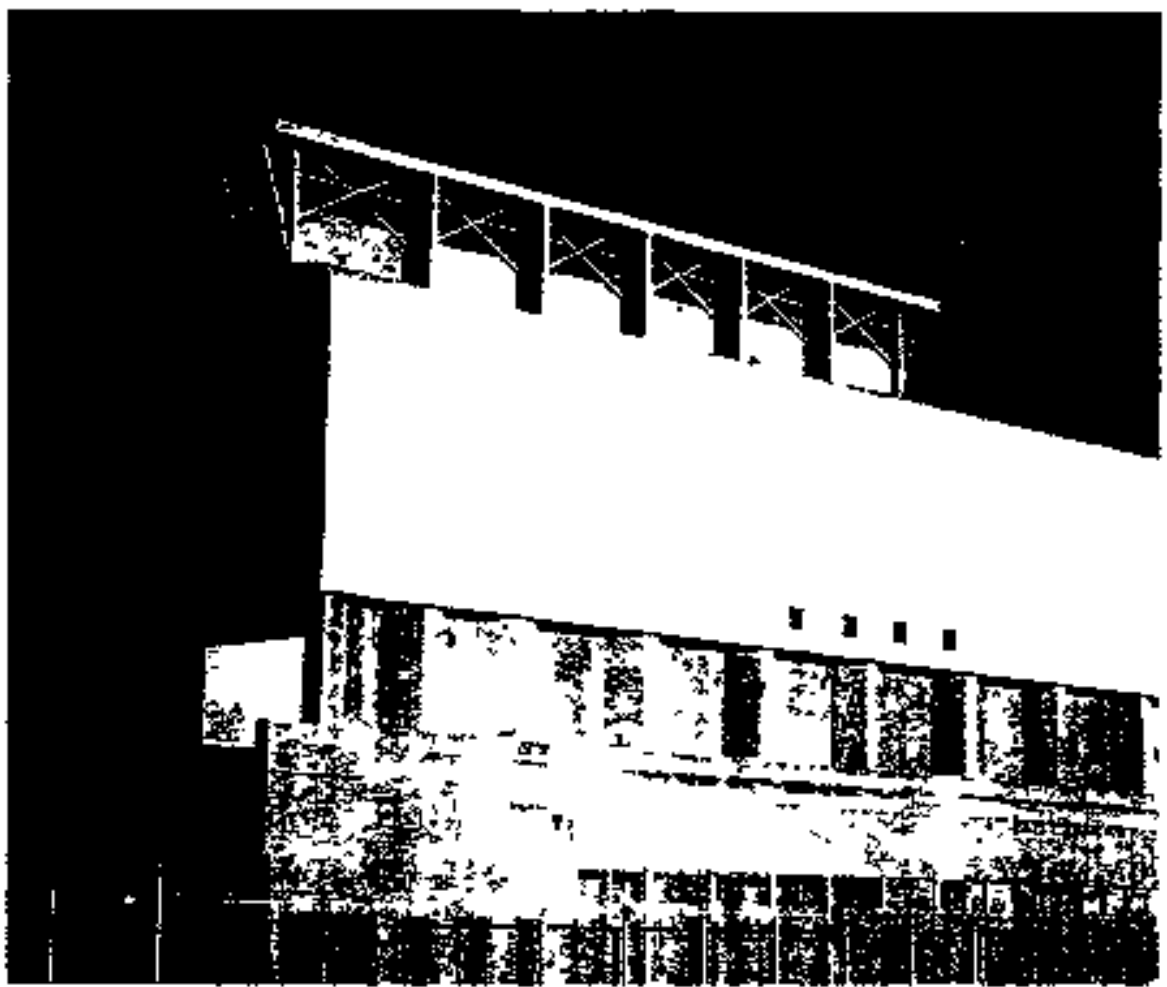

A modutar vauth dry storage facifity operated by the Publte Service Compony of Colorado built to hold spent nuclear fuel. storage technologies already in operauon and demonstrated to be safe

The U.S. Deparment of Energy (DOE) is responsible for the Nation's Civilian Radioactive Waste Management System. Withun DOE, the Office of Civilian Radioactive Waste Managernent (OCRWM) is chasged with exectung policy and managing the program to safely dispose of used nitelear fuel and other forms of high-level radioactive waste.

For more isformation, please write: OCRWM information Center Post Ofifice Box 44375 Washington. DC 20026 or call 1-800-225-NWPA (or coll 488-5513 in Wastungton, D C)

Published by the US Deparimert of Eneryy Orfice of Civilidn Radwodate Wate Manapement (OCRWM)

\section{Please recyite}

August 1992 


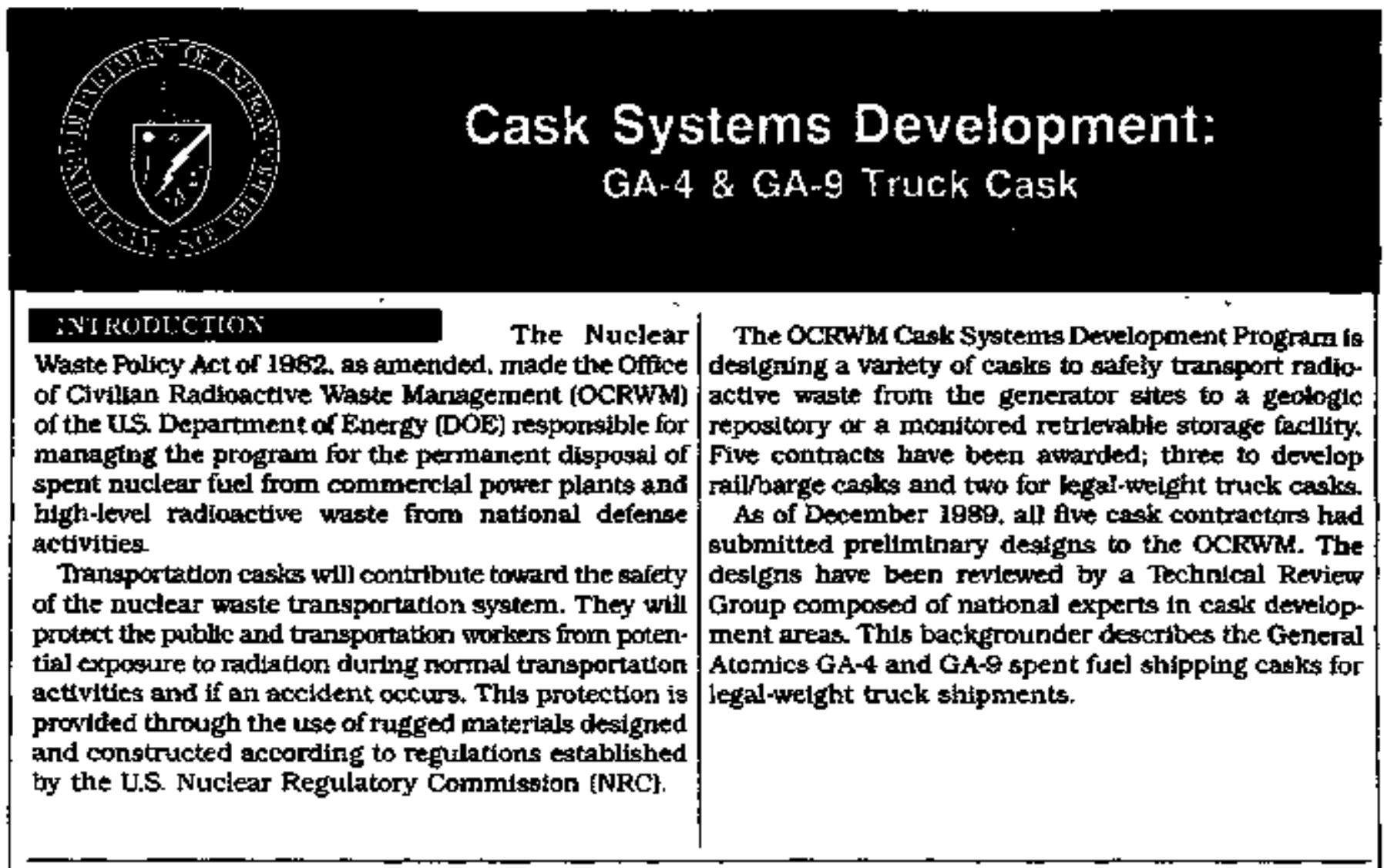

Continctor

General Atomics Corporation San Diega Callíñmia

beat तites

square cask cavity

Two specialized designs: one exclustrety for pressurized. water ractor [PWR] and another exclusively for boiting-water reactor (BWR) fuel.

Payload

4 PWR (GA-4) क 9 BWR (GA-9) jntact fuel assemblies

Structural material

Stainiless steel

Basket

Stainless steel

Ganma shielding Depleted utranium

Neutron shielding Borated polyethylene

Closure type Bolted

Impact limiters

Aluninum honeycomb with stainless stetl shell

\section{Ty gic of Cask}

27-tom jegal-witght truck shipping casks

\section{Sizs}

Length-19.5' (GA-4) and 20.3. $3^{2}$ (G-9)

Diameter-7.5' and 7.5'

(wth impact limiters)

Weight-26.3 and 26.45 tons

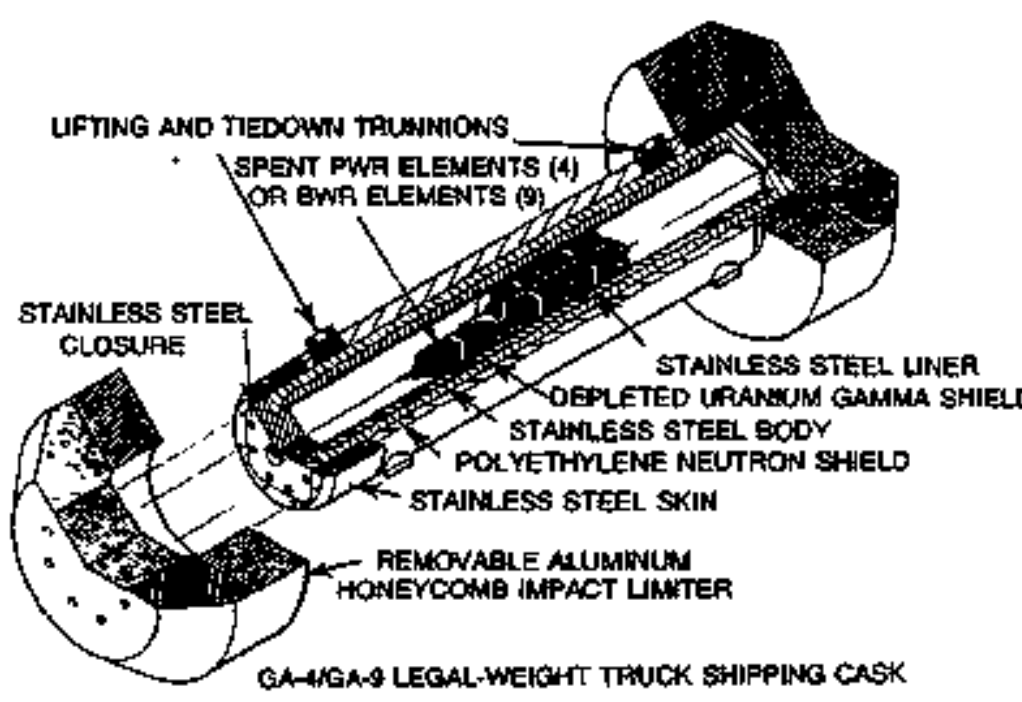


General Atomics Corporation $\mathrm{C}_{\mathbf{x}} \mathrm{A}-4$ and $\mathrm{C} A-9$

27-Ion Legal-Weight Truck Stipring Casks

General Atomics Corporation's GA-4 and GA-9 are two speclalized shipping cask designs: one for pressurlzed-water reactor firel assemblies and the other for bolling-water reactor fuel assemblies. The casks' stainless steel structural material has distinctive shaped cross-sections that minimize weight and maximize payload. Neutron shleiding is provided by borated polyethylene and the gamma shielding is constructed of depleted uranium. The removable impact limiters are made from aluminum honeycomb with a stalnkess steci shell.
Casks mut meet design performance standards, testIng condftions. and certification requirements established by the NRC. Cask design certification applications must demonstrate to the NRC. through analysis andor testing, that casks can withstand both normal transportation and accident conditions, as specifjed in Federal regulations.
Pabliated by the Ofice of Extertid Reticions and Policy

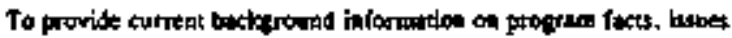

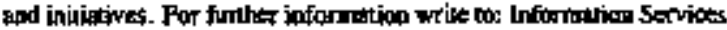

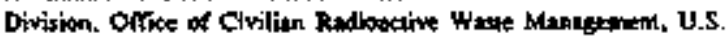

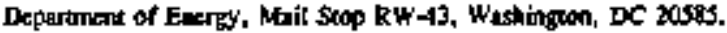

Inte:terce Giridelines.

Catsk Sizt:hilightst Lirtits

Diameter-6

Helght (Length)-Limited by headroom

Headroom-22'

Casic loading height-18'

Gross vehicle weight-40 tons (max.) including tractor, trailer. and loaded cask
Shipping Cask with Personnel Barrier on Truck Trailer

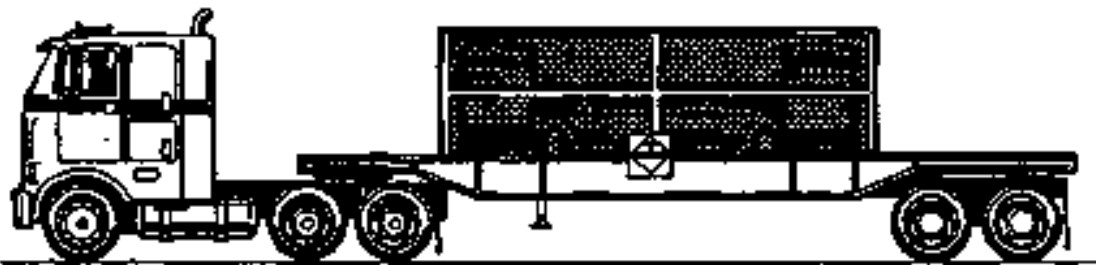




\section{Appendix E}

Backup Data for SNF Rail Shipments

Appendlx E-1: IF-300 Product Literature Appendix E-2: BR 100 Design Information

Appendlx E-3: M-140 Cost Information Appendix E-4: Railroad Rate Quotations 



\section{Appendhx E-1}

IF-300 Product Literature 
NEDO-10864C

79NED47R

Class I

July 1983

\title{
General Description
}

\author{
IF-300 \\ Irradiated \\ Fuel Transportation \\ System
}

NUCLEAR ENERGY BUSINESS OPERATIONS - BENERAL ELECTAIC COMPANY SMN JOSE, CALIFORNIA \$S12S 


\section{DISCLAIMEA OF RESPONSIEILITY}

This general description was prepared by Genert Electric Company and is being made avaliable without consideration. General Electric Company does not:

A. Make any warranty or represtentation, expressed or impliod, with respect to the focuracy, completeness, or usefulness of the information con tained in this reprit, or thet the use of any intomation disclosed in this report may not infinge privetely owned rights; or

8. Assume any responsibisity lor liabitity or demage which may resutt from the use of eny information disclosed or contained in this general descrip. tion document. 


\section{CONTENTS}

Deston Summary

Cask

Skid and Supports.

Cooking Syatem

$+9$

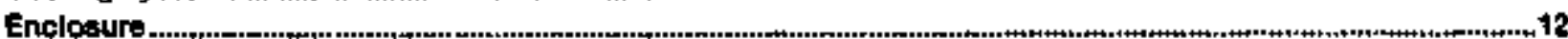

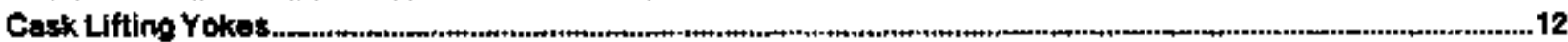

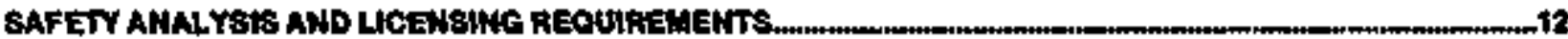

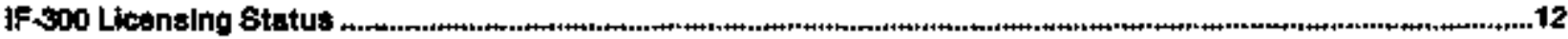

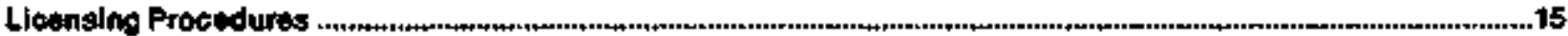

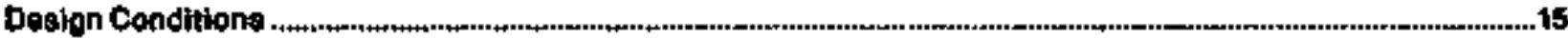

EXPEAIEACE.

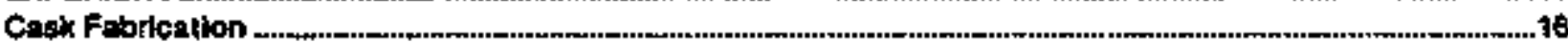

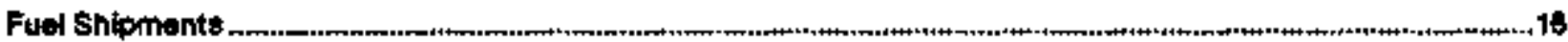

TRANSPORTATHON SUPPORT SERMCES .

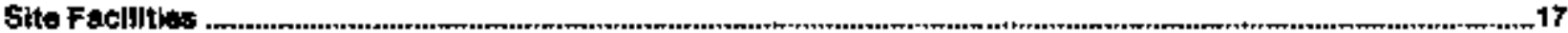

Pre-Snipment Preparations

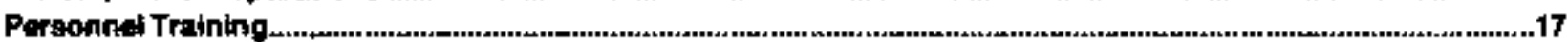

StMMARY 17

\section{ILLUSTRATIONS}

Fhorit

1 IF-300 Irradiated Fuel Transportation Syetem in Normal Fiall Configuration

$2 \quad$ FF-300 Iradiated Fül Shipping Cask

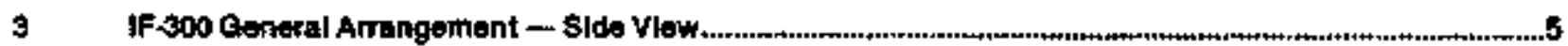

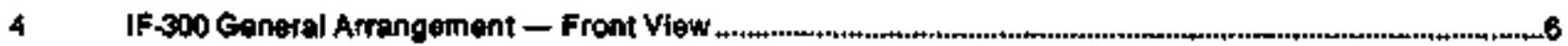

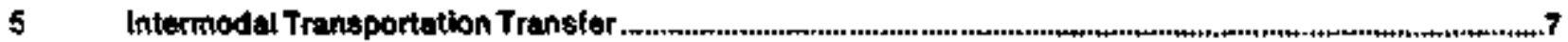

6 Typlcal Fuel ganaket Spacer Discs — EWPJPWR...............................................................................10

7 Whiting Arrangement of Redundant Yoke Assembly .............................................................................. 13

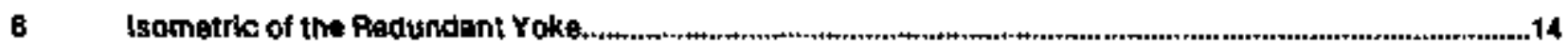




\section{FEATURES OF THE IF-3OO IRRADIATEO FUEL TRANSPORTATION SYSTEM}

The IF-300 Irradiated Fuel Transportation System is designed to transport Irradiated (spent) nuclear fusf in accordance with the requirements of the Nuclear Regulatory Commission (NRC), and the Department of Transportation." The system is operational under Certificate of Compliance 9001, which was originally issued by the NRC (then Alomic Energy Commissioni in 1973. At the present time, this Certificate permits shipment of all currently used Eoiling (BWA) and Pressurized (PWP) Water Feactor fuet in a dry mode. Fuels ot nominal burnup can be shipped after approximalely 2-1/2 years of cooling time. The cask is presently utlilzed in a "zero. release" configuration and uses a pupture disk device for overpressure protection rather than the original controlled-release valve.

The IF-300, which has a capecty of 7 PWR or 18 BWR bundles, was the first multi-bundle cask with the neutron shieioling required for high exposure fuel. It is the only multi-bundle cask with actual operating experience and is noted for its relative compactness and ease of handling in currently operating nuclear stations.

Capacity, weight, and dimensional speclfications of the If-300 are as follows:

\section{Capactity}

Bundleg.

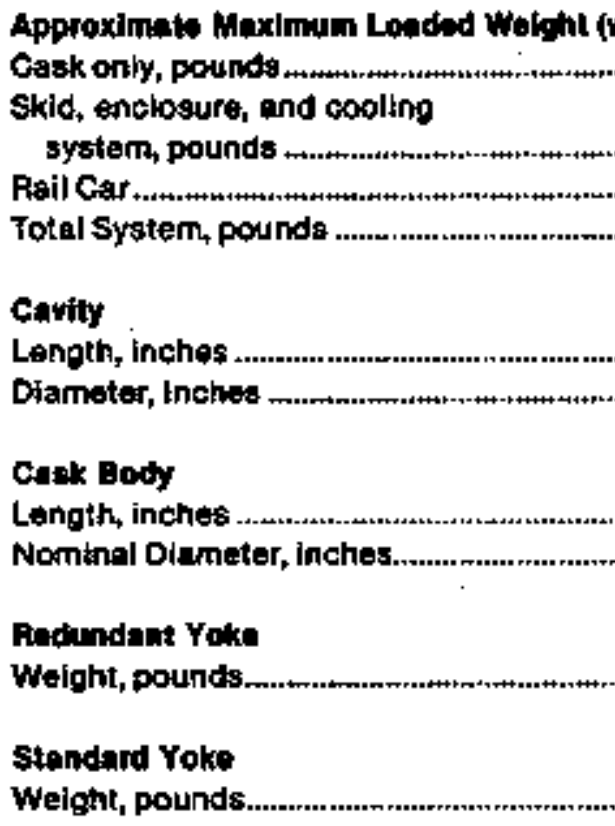

stiv

Length, feet

width, feet

Host Olssipution

Btwhr
BWh

18

140,000

45,000

75,000

260,000

180

37.5

208

64

15,000

5,000

37.5

8

40,000
PWA

7

138,000

46,000

75,000

256,000

169

37.5

196

64

15,000

5,000

37.5

8

40,000

-U.S. Cada of Fedoral Ragulationt. 10CFA?1 and 4hCFP17

-Weight of water in cask when renowed inom poed is approximately 4,600 pounds. 


\section{EQUIPMENT DESCRIPTION}

\section{DESIGN BUMMAAY (Figuren 1,2,3,4, and 5)}

The General Electric IF-300 Irradiated Fuel Transportation System is designed to ship 18 BWR bundles or 7 PWA fuel bundies. The various loads are individually accommodated through the use of removabie fuel bas. kets and two different length closisre neads.

Trapsportation is primarly by rail, although the skfd is des lgned to acoept wheel assemblles for shorthaul, speclal permit trucking. This duarmode ahipping conflguration permits the use of the IF-300 cask at those reactor sites which have no direct rall access. The short-heul capebitity is used to move the cask and equipment skid to the nearest conventent railhead, where It can be tranafered to lts railroad cer uging rolt-ontoll-ofł tectniques.

The cask ls mounted on the skid in a horizomtal position durting traneport. It le supporled on the akid by a saddlo at the head and and a cradle at the botton end. The cradie torms the piryot about which the cask is rotated for verticel removal from the skid. There is one pickup position on the cask body just betow the closuce flange. Af this same location, the support suddle ongeges the cask.

The cask is lifted by a special yoke, designed to be used with etther lengith head. This yoke accepts ins normal reactor buliding crone hook in lta upper and and engeges the cask lifting trunnions with two hooks on its lower end. The cask head is removed usine four steel cables which are part of the yoke. A single yoke is used lor hoth cesk rofation and cask lifting. Also tavalable, where needed, is a tedundant llftino yoke designeo 10 interface with singte fallureproor reactor building cranes. The redundani yoke is a necessary companent of the critioal loed littino system installed in certain reactor plants to provide protection againat the occurrence of a cesk drop eccildent.

All external and iaternal surfaces of the cask are stainless steel, Both pamma and nevtron shieldino are provided by the deplated uranium metal within the cask shell and by the exterfor water-fllied anntilar enclosure. This enclosure is fabricated from thin-walled stainless steel and is comugated to maximize the heat transfer ares. These corrupations also signifleantly Increase the strexuth of the outer jackel end its reslstance to damape. The annular neutron ahlelding enclosure is attached to the cask body and masks the active fuel zone.

The cask cavity is sealed with a metallic pasket at the cask closure head. The maximum normal operating pressure of the cask cavity In the diy mode is less than 25 psig. However, the design working pressure is 400 ps/O al a cask body temperature of gts" F. Overpressure protection is prowided by a rupture disk, with a burst presetere range of 350 to 400 psig at $443^{\circ} \mathrm{F}$. The cask cavity is equipped with two nuctear service valves, one in each of two valve boxes, for tijling, draining, venting, and sampling. These valves have quick disconnect fittings for oase in servicing. Both valve handles are secured during transit to prevent lampering. The neutron ahielding water enclosure is protected from overpressufe by a 200-paig peliet valve. It ls aerviced by fill and draln valves toceted in the two value boxes.

Fuel burdles are containad within a removable, slotted, stainiess steel bagket. Two alternate baskets are available, and dealgned to accommodate AWR bundles and one for the PWR bundles. Fuef bundles are restratined axtally by spacers mounted on the Insida of the closure head. The besket is centered within the cask cavity by nine specer discs, mounted along the fuel basket length. Fuel bundles are inserted and removed from the basket using standerd grapples. Criticality controt is achieved by using B.C-filled stainless steel tubes within the basket. 


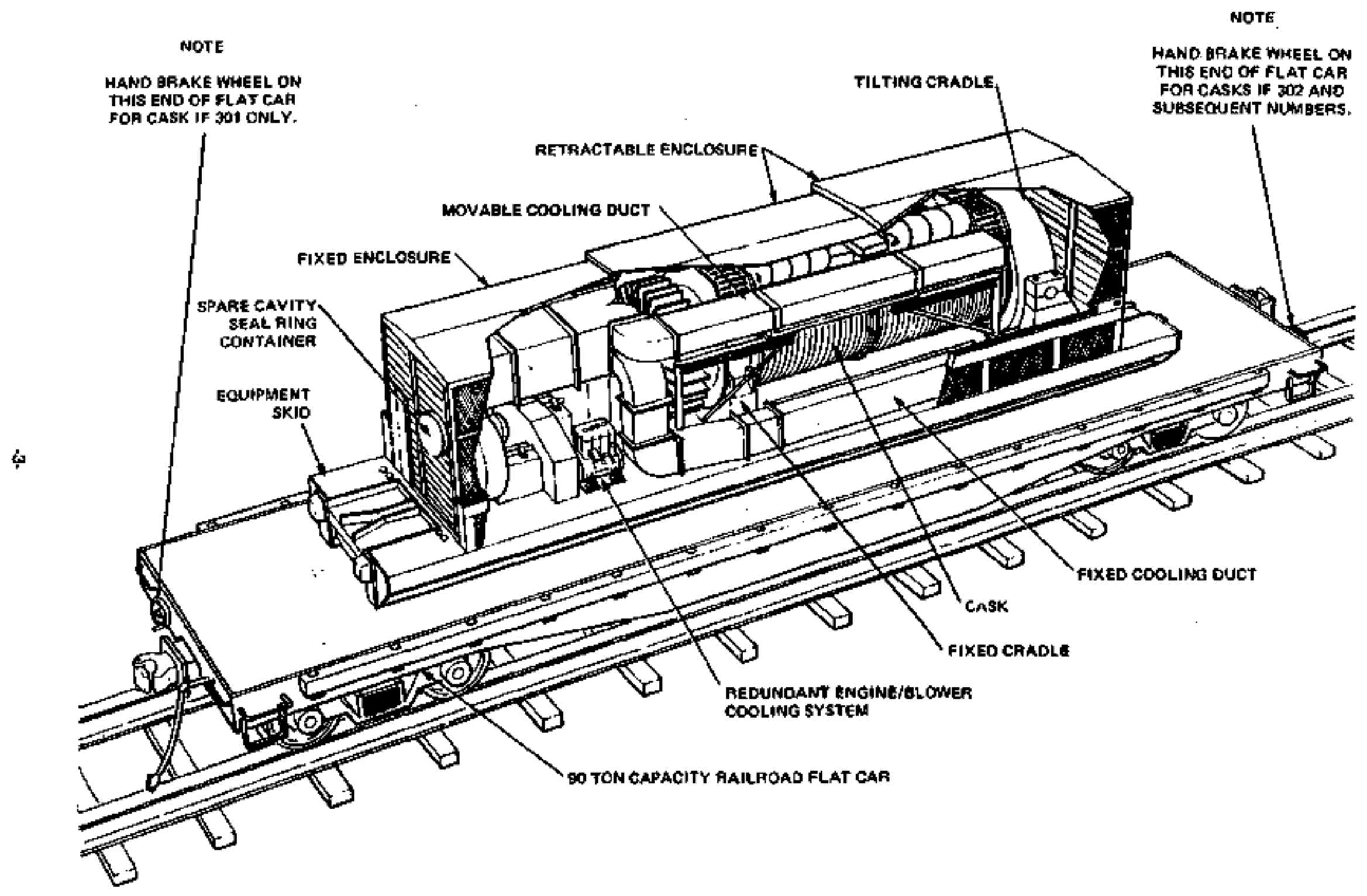

Flgure 1. If-300 irradiated Ftwel Transportetton System in Narmel Aell Conflguration 


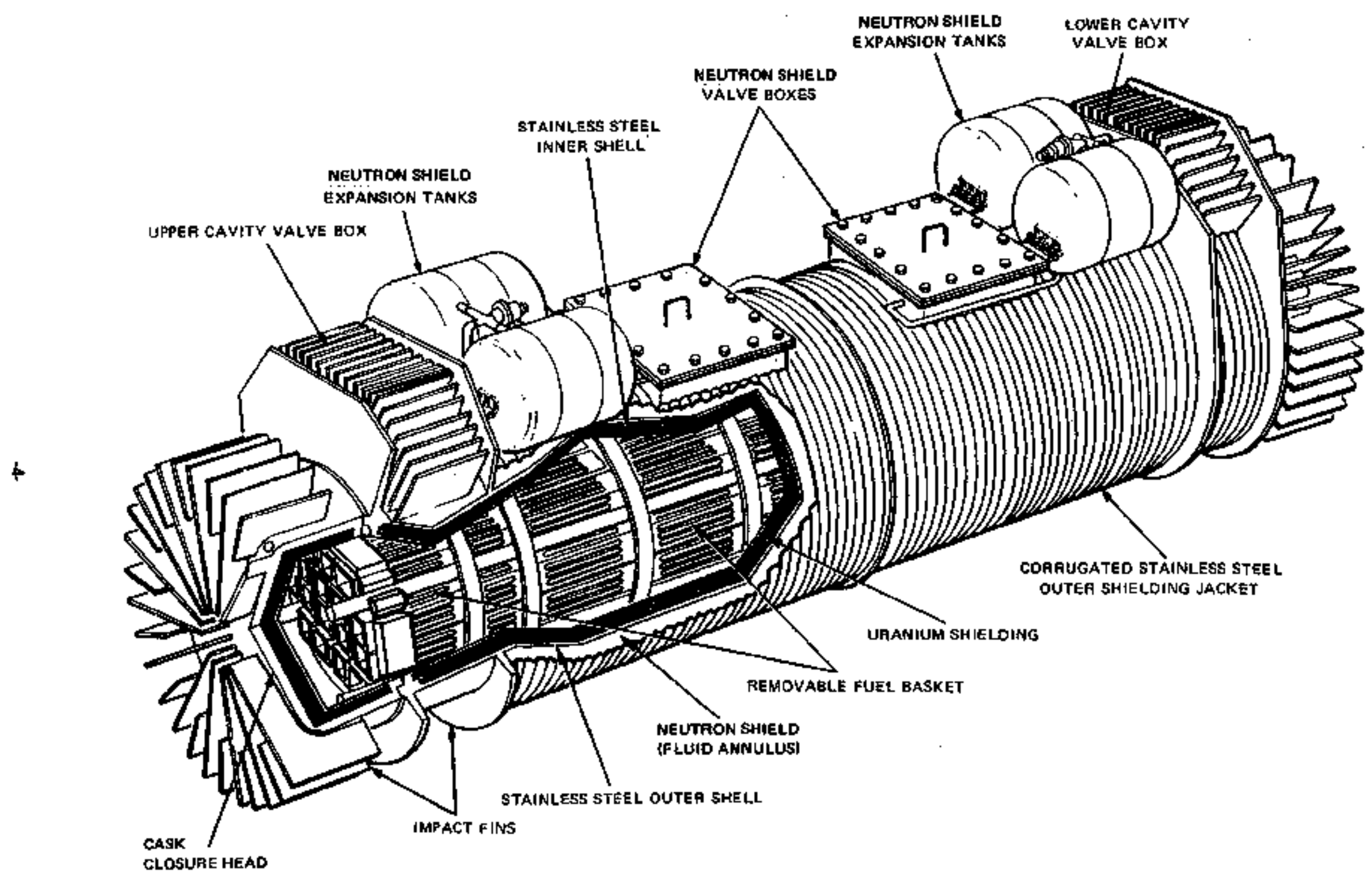

Figure 2. if-300 irradiated Fuel Shipping Cask 
$\phi$

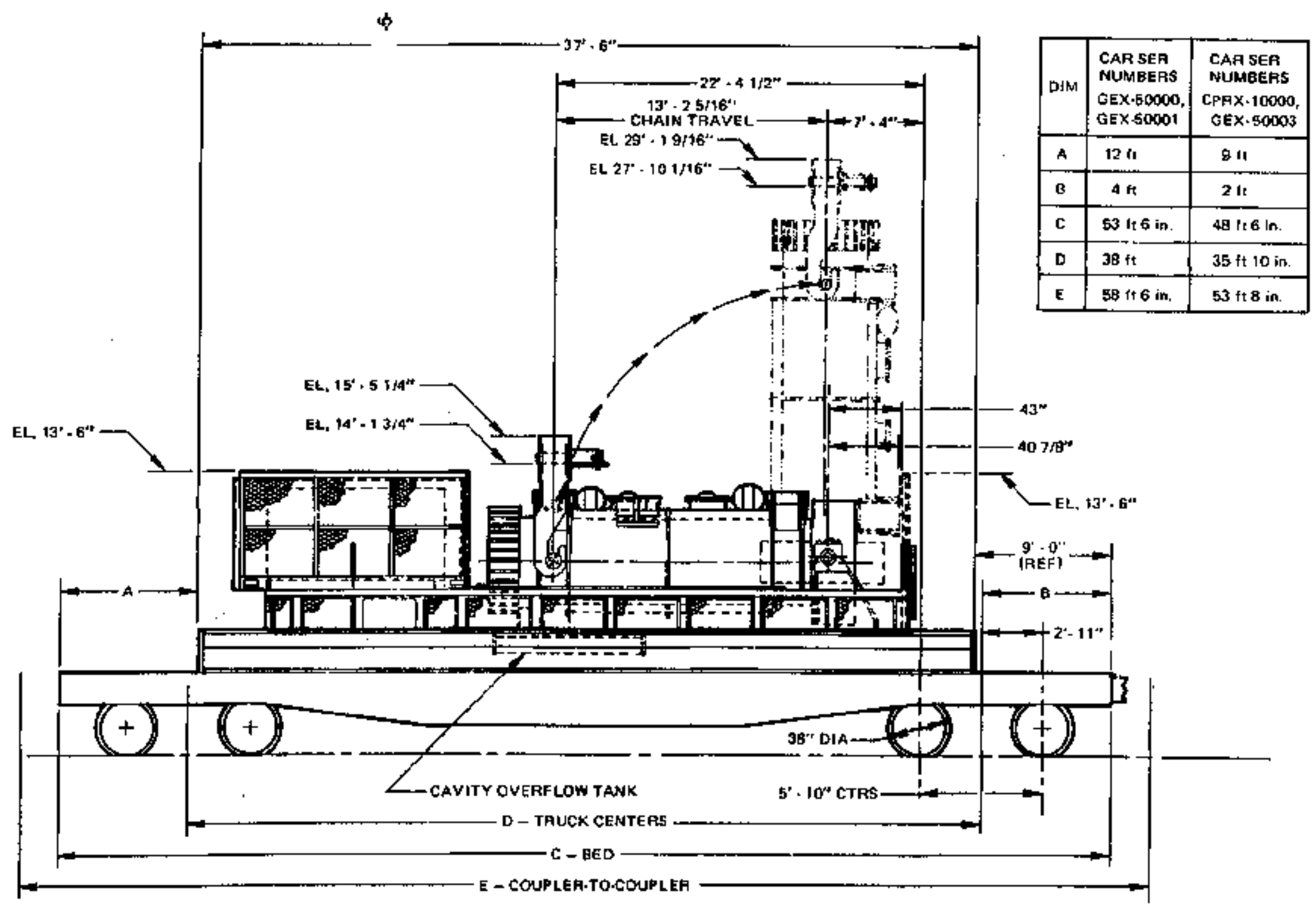

Figure 3. IF-300 Goperal Arrangement - Side Vlew 


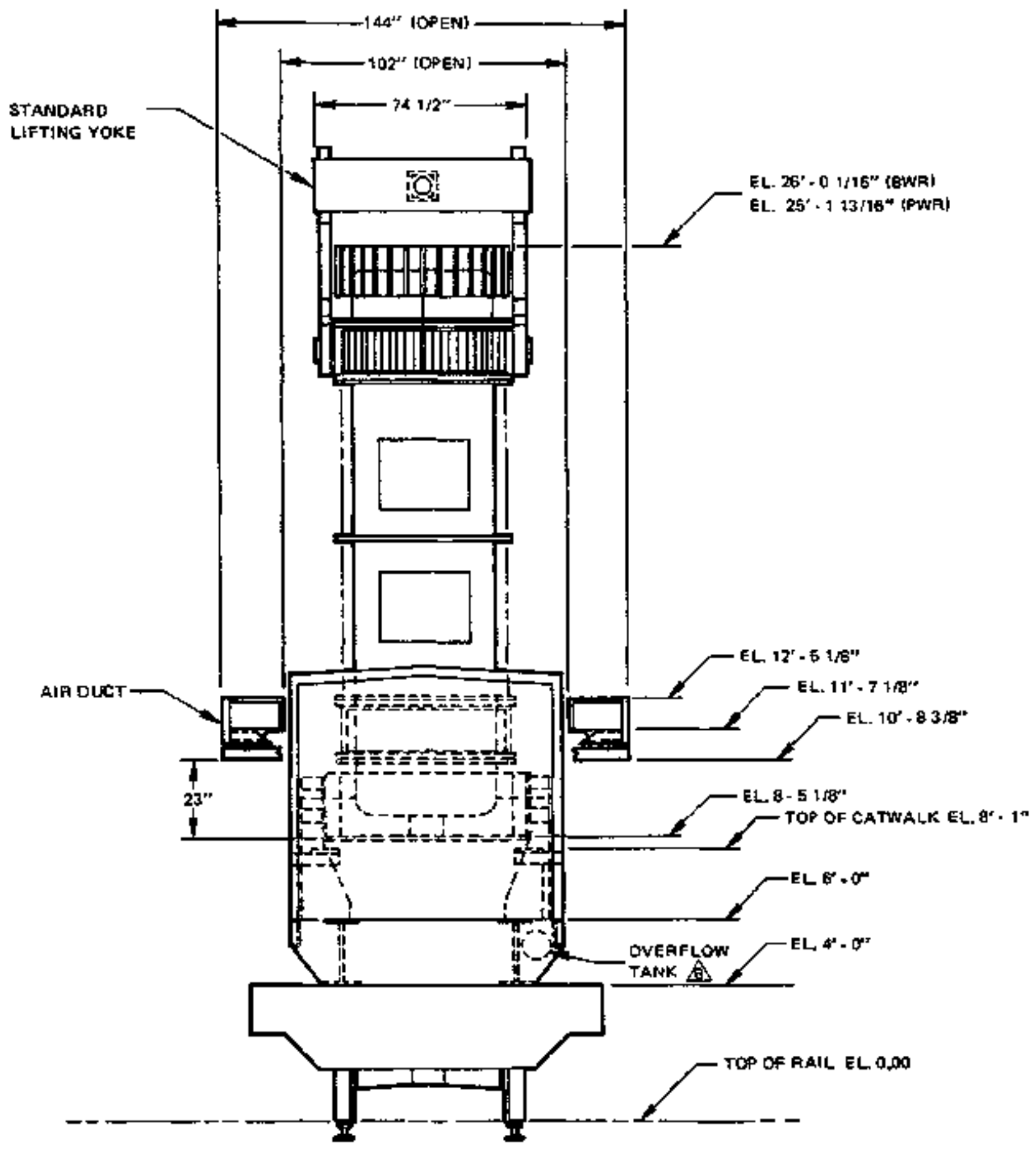

Flgure 4. IF-300 General Arrangement - Front Vlew 

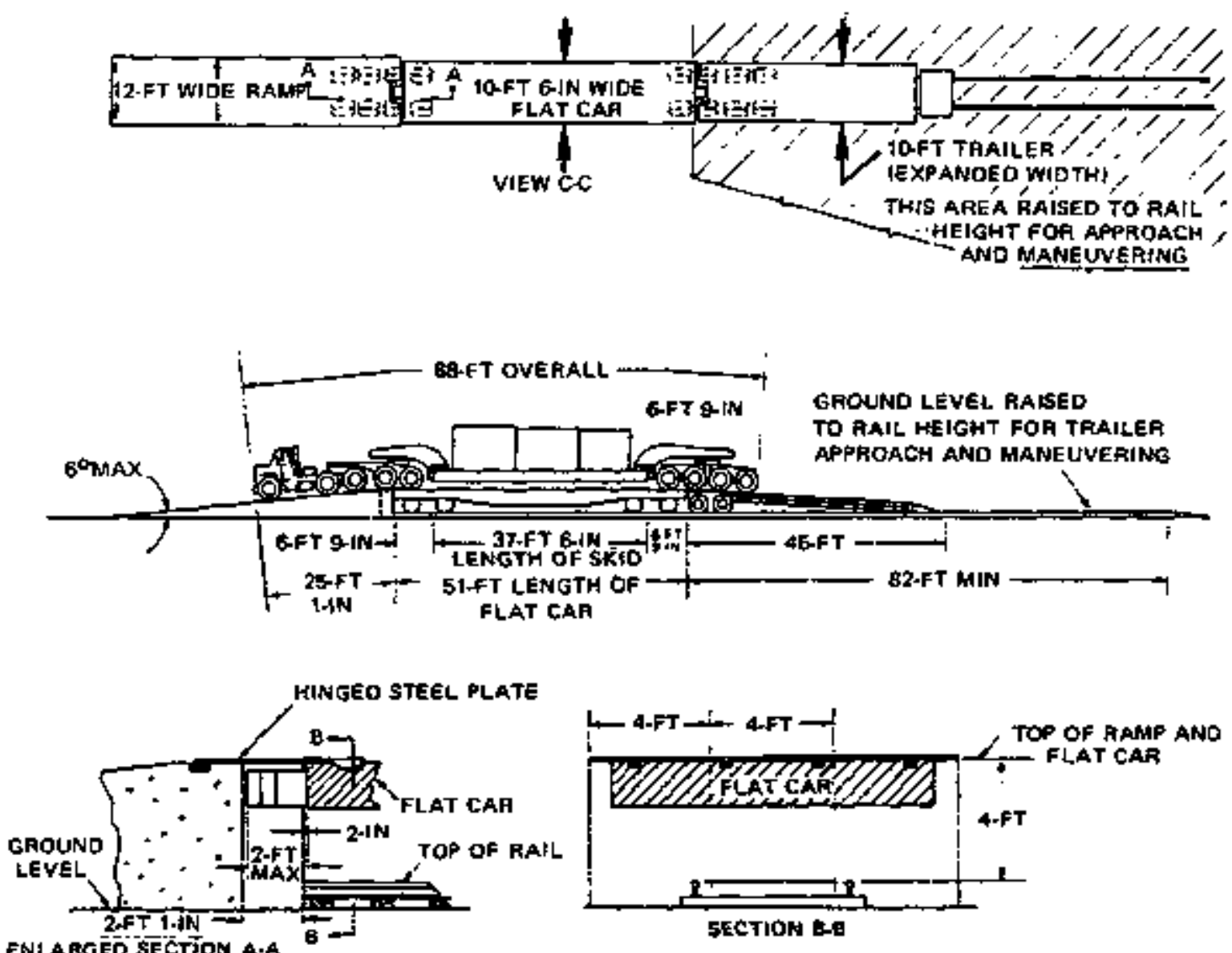

Figure 5. Imtermodal Teasportetion Tronafer

Cask

\section{Cenk Body}

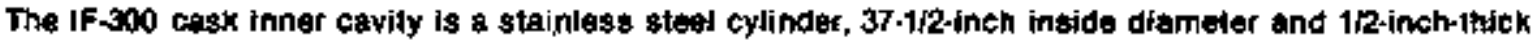
wals, having lts boltom end sealed wh a 1+7/76. inch-thick stalnieas steel plate. The upper end is weided 10 ine closife flange. Processes and procedures described in Section It of the ASME Code were used for guldance In the fabrication of the cask.

Surrounding the inner cavtly is the depleted uranitum metel shieiding material. Thks heavy metal assembly consists of annular cosilings, each with a 3a-1/2+inch i.d. and a 4+inch+thick wall. Sections are intarlockpd, end-10. end, using an crerlapping jolnt which holds the stack together and prevents radiation streaming. This assembly is shrink-litied to the tnner cavity to ensure good thermal contafl for heat transfer purposes. The boltom end shidito is $\$$ 3-3/-inch-thick uranium metal casting.

To prevery the formation of a low melting point alloy of steel and uranium, a 5.mit-thick copper diftusion barfler is provided at every turanium-stegt interface. This berrier is olated or trame-spayed on the iaroer pieces such as the taner and outer shells. Copper foil is used in some of the smaller areas.

The cuter body shell is aiso a stainless steel cylinder with a $46 \cdot 1 / 2 \cdot$ tnch $1 . d$ and a $1 \cdot 1 / 2 \cdot$ inch-lhick wall. The oujegr shell is also shrink. fitied to the uranium to ensure good heat transter characteristics. 
The outer body shell of the cask is encircled by a thln+walled, corrugated stainless steel water enclosure jacket, extenditng axially from the upper valve box to a polnt slightly above the cask bottom, thus masking the active fuel zone. Water contained in thls annular enctasure functions as a neutron shiald. An antifreeze and water mixtuse is used when the cask is subject to cold ambient temperetuje conditions. The jacket surface is corrugated for heat transter purposes. Addftionaliy, the use of continuouss corfugation provides a surface which is easily decontaminated. The jacket has a pressure rating of $200 \mathrm{psig}$ and is equipped with tili, Ilush, and pressure relief valves.

Welded to the outer shetl are tour 1-1/4-koh-thlck clrcumferential fina. These members aerve as lifting riwo and impact fins. They are also used to support the water jacket secilons. The lf 300 cask is litted by a set of trunnions located Just below the closure heud fienge. These lifting trunnions are pinned to the upper palr of hoavy rings and are dealgned to be remeved tor transit. The upper pair of lifiling finga also acts as the forward supportaxial kestratint when the cask is in the horizentel transport position.

Radiafly mounted at the lower end of the cask are 32 staimless steel impect fink, 1.1/4 inches thick Sixteen protrude 8-1/8 inches from the surface and the remeining protsude 6 inches. They are welded in place and prepared for ease of decontaminathon.

There are two large yalve boxes on the exterlor of the cask body nested betwean the pairs of impact fins. These fixtures have finned lids which are removed during loading and unloading. The thead end valve box contains both a nuclear service vent and flush vative and a rupture d/sc device. The lowe bex contains a ftill and flush valve only. Stainiess steel Schedule 40 pipe connects the upper valwe and the rupture disk device to the cask cavity side wall near the flange. The lower value is connected to the inner cavity bottom, 180 degrees from the upper value tocation. Both the stainiess steel vent and ilush valves are equipped with quitck disconnect fittings.

Tempertuse monitoring is performed with a thermocouple mounted between the uranlam and the inner cavity. This thermocoupte is located equidistart from the ends of the cask bocy at what is expectec to be the nottest axisl point. The thermocouple is contained within a wetl which enters the bottom of the cask, thes per. mitting easy replacement.

The overall langth of the cask body from fins to flange face is 184-3/18 inches. The cask cavlty depth from the fiange face is 168.12 inehes. The flange ts a stalnless steel machined forging whose face contalns 32 equelly spaced studs, each of which is $1-3 / 4$ inches in diameter. The stude protrude $6-3 / 4$ inctes from the face and are made of 17-4 PH stainiess steel.

\section{Cakk Closure Hands}

The IF-s00 cask can be equipped with either of two different cask closure heads. These cask closure heads provide two altormato cask cavily lengthe to match the particutar dirmensions of the fuel belng shipped. With the short cask olosure head In place, the overell cavity lengin is 169-1/2 inchea. The long cask closure head Increases the cavity to 180 inches. Most PWR furel will be ahipped waing the short cask olosure (PWR) head. EWR fuel (and seane honger designs of PWR fuel) will necessitese using the extended cask chosure (BWA) heed.

Shielding in the cask closture hesds consists of 3 inches of uranlum. The outer shell and flange is a single stainless steel mochined casting. A cisoular steinless steel plate is wetded in pisce to form the cask closure: haed cover. As in the case of the cask body assembly, each stevturanium interfece is isolated with a 5-mlt cop. per Jeyer.

Each cask closure head has 32 radially mounted fins on the end, 16 of which protrude $0-1 / 2$ inches from the surtace. The remaining flins protzude of Inches from the surface. These fins ere designed to prowlde inpact protection to the cask and contents. These fins ere slainless steel and are wolded in place. 
Because of variations in fuel lengths, it is necessary to provide some spacing scheme. There are tive spacer assemblies for the two cask closure hoads. These spacers ave mounted an circular plates which bolt to the top of the cask closure head cavity. Spacing is accomplished with struts and pads whlch proinude from the circular plate. Several sizes of besket botion spacers are provlded to elevate shot bundles. Each ptate is numbered and indexed to ensure proper Installation.

\section{Closure}

The cask body is joined to either hoad, using the 32 studs in the body ftange and an equal number of special steeve nuts. Short, 3-1/2-inch-leng1h nuts are used to secure the PWR cask closure head assembly. Because of its greater length, the BWR cask closure head must uttize 13-3/4-inch-long slesve nuts. Using the sleave nut approach makes it possible to change cask chosure heads without changing the studs. Two gulde pless prowlde alighment and oriensation.

Cask sealino is acoomplished using a metallic gasket. The cesk closure head and body flanges interlock to provlde shear steps to protect the gasket in cose of impact.

\section{Fual Backits (Flowe o)}

Two different fued baskets may be used in the IF- 300 cask - a 7-cell FWR unit and an 18-cell BWR unit.

Each basket "cedp" has walts which are slotted to prowde coolant flow to the contained fuel. Celis are theld in place by nine ciccutar spacers equally placed atong the besket length. These same spacers oenter the basket in the cask covily. The basket colls rua the full length of the fuel and function as outides for in fuel loading. When the cask is horizontal, the weight of the fuet bundles is cerried by the specar diacs.

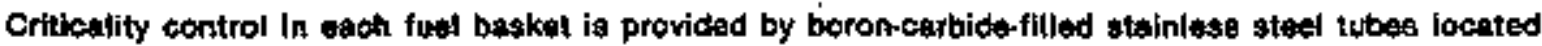
adjacent to tha beaket cells. Design end fabrtcation of these tubes follow GE'BWR practice for control rod blade absocber rods.

Both beskets are of welded, stainless steel construction. Each is keyed into the cask to prevent rotation during shiptiment. Basket removal is accomplished usino a special basket removal yoke which ongages two tifting apes at the upper end of the assembly.

\section{SKID ANO SUPPORTS}

\section{Equipenand stid (Foure 2)}

The aquipment skid functions as both a unitzed paliet for the cask and cooling equipment and a trailer deok for speciat permit short haul trucking.

The akjd frame uses 24-inch fabricated lbeams, Fuel tanks for the cocling system diesel engines are Incorporated Into the traming. The coollng system and cask support members we attached directly to the trame. The skid is 37-1/2 fenet long, 8 feet wide, and fis of all-steel construction. Both ends of the skid are degigned to accept a type of hyorastit pooseneck assembles used in the heavy havling industry. When transporting the package by tuuck, whoeled assemblins will bo atlached to both ends of the skid. The gocseneck will be vaed to lift the unti to a minimum road clearance of 12 inches. Deck plate is prowlded for all accessible aroas.

Durlng rell shipment, the skid sits directly on the bed of a alightly moditied standard 90-ton-capecity flat esr. During transport, the skld ls restrained by a securing system deaigned to resist the peak foads anticipated under nomal railesed concitions for the hydraulicalty cushioned draft gear. 


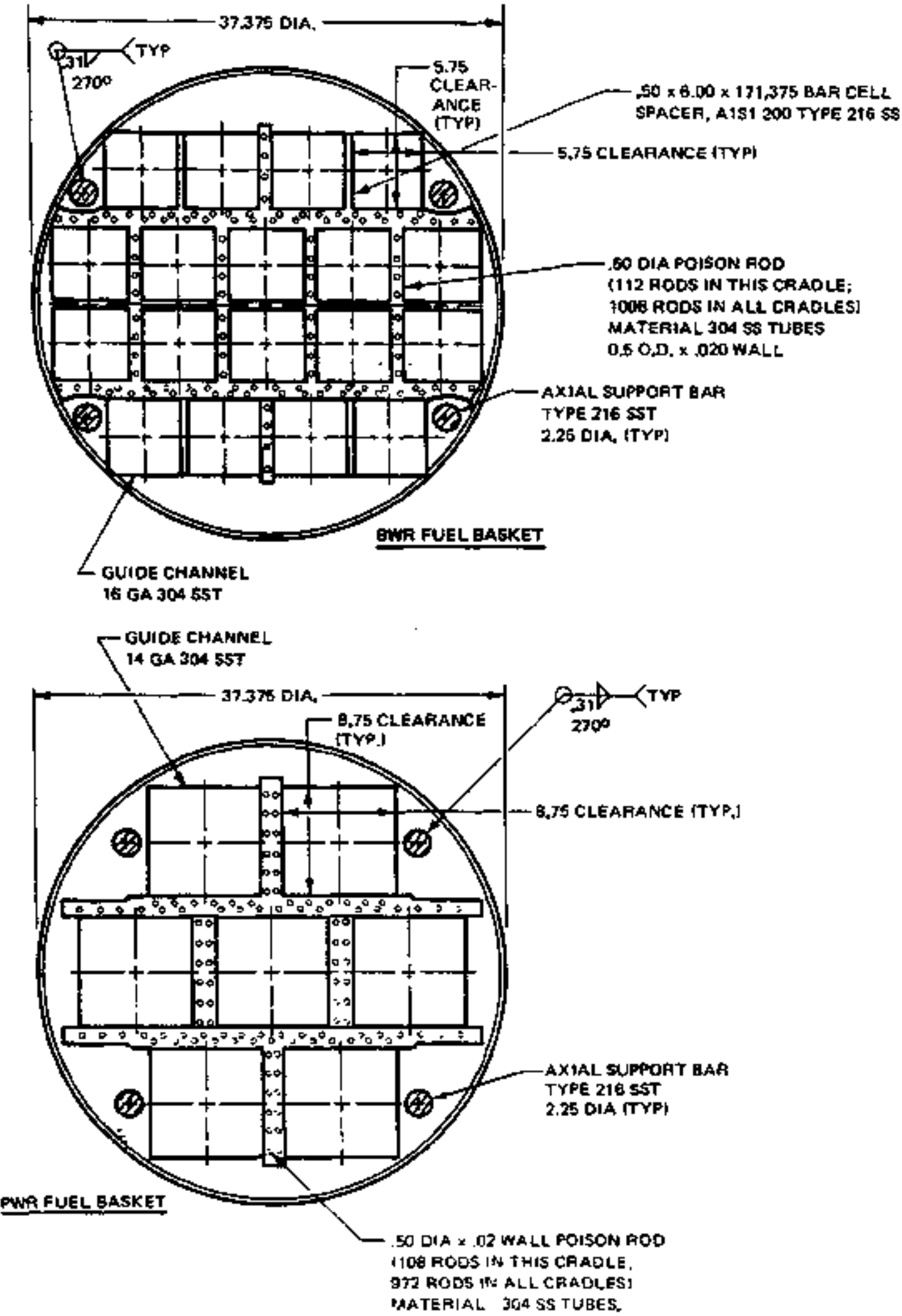

figure 6. Typrcat Fuel 8asket Spacer Dises - BWR/PWA 


\section{Cask Supports}

The horlzontasly iransported cesk is supported in two locations; fust below the closure flange by a saddle and at the cask base by a plwot cradile.

Congtructed of ASTM A516 Gr70 steel, the support aaddle for the head end is walded directly to the skid frame. This thaheped structure engages the cask at lts upper lifting rings. Hendened pins are Inserted through the lifting rings to provide restraint of the head ento of the cask in the vertlcal and lateral directions, and through the saodle ears to fuenlsh axlal restralnt for the total cask weight. During the lowering operation, contact between the gaddle and one lifting ing moves the cask forward, slightiy away from the bottom of the rear support. This movenent provides end clearance for the differential themal expansion of the cask and skid cemponents.

The plyot tradle, congisting of two pedestals which are welded directly to the skid fratie and a counterbulanesd cradle or "cup," supports the buse of thi cusk. The oradle pivots between the pedestals on two trunnions. When the cask la remored, the "cup" remsins in a hoflzontal posttion with fts open end upward. Duritro the replacement operation, the cask base is lowered Into the "cup." Two hardened guides provide alkgnment.

Once the cask is geated in the cradle, the plvot cradte and "cup" are rotated downwerd to the normal transport postition. A shoe on the cask base becomes the bearting surface between the cradie and cask when in the transport position. All contact surfaces are costed with a lubricant to reduce the friction when the cask is moved forward for expansion ciparance.

The Iwo cradle-mounted tipping trunnions are held in the pedestuls by pillowblocks, each having a lutycated phosphor bronze bushing, to prevent galling. The cradke is counterweighted with lead to hald it in sn upright position when the cask is removed. The trunnions are mounted on the cradie slighily off-senter so that there is a netural tipptng direction toward the cooling system end of the skid when the cask is rotated. Both the cradle and padestals are constructed from A8TM A516 Gr 70 steet.

\section{COOLING SYSTEM}

Exterinal coak coofing is not newded for nuclear safety and theretore is not required by the cask Certificate of Compliance. An external cooling system is provided to maintain ressonable cask surface temperaitures lor cask haindling with high heat load fuel.

Cask surface cooling is accompllshed uaing a unlque alr jet Impingement techalque. Alr, at a velocity of 47 teet per second, is directed perpendicular to the cask surtace from four ducts, wming the length of the cask and 90 degrees aparh, bieecting the four quadrants. The two lower ducts are flxed to the skid whlie the two upper ducts lock In place during transit, but move outward to facilitate cask romovat.

Each enginatolower unit is independent of the others and eapable of producing a minimum flow of 10,000 cublc feex of alr per minute. Duzino normal coseration, both unlte will be run simulteneously, delwering $=18,000$ $\mathrm{cfm}$ to the cask surfece. Fuel tanke which are located in the skid, have a total capacity of $\$ 70$ gations. Thls quantity witl permit the contiowouse running of both units tor at lesel 10 days. Either cow of the tinits is capable of supplying aufiticient air to cool the cask uurfece.

Both btowers discharge into a common air ptenum, which feeds the four axial ducts that coct the cask. If one blower falls, a gravity dimper prowents a back-flow of alr from the plenum. Intakes are well isoleted and are located withith a screened enciosure to prevent debris ingertion. 
NEDO-10834C

\section{ENCLOSURE}

The cask and cooling system is enciosed by an aluminum frame and expanded metal cage. This enclosure is in three sections: two are ower the cask and the InIrd covers the cooling system. The Iwo cask enclosures move slong a rall and telescope over the third one, which is semi-permantent, to facilltats cask semoval. The encksure ends are aiso sernt-permenently attached to the skld. The cage extends out to the edge of the b-foot wide skid. When the movable sections are retracted, the ralfs form a sils, which protects the botlom ducting and provides a work platform along the cask. Whon the sections are in place over the cask, a locking devlce lifts them off of their tracks and secures their movernent. This device is locked during transit.

The coollng equipment end wath has a lockabls access door for Inspection in addition, there ls one smalt removabie panel on each side of the equipreant enclosure which permits access to each of the eng inethlower instrument consolet. The equlpment enclosure and the end walis may be renoved by unbotting.

All three sections have solid roofs for sun ahading. The enclosure ends are also solid. This ontire enctosure makes the noarest accessible shipping packege surface approximatery 4 feet trom the cask centẹrtne.

\section{CASK LVTTNO YOKES (Floures 7 and B)}

The stendard cessk lifting yoke la a steel atructure which engages a bullding crene at the top and the IF-300 cagk Liftimg trunnions at the bottom. This yoke is used for all cask handling operatlons includting remoral ard replacement on the equipment skid, insertion in the fuel pool, and cask clipsure hend removel and instalsetlan. The upper engegement with the building crene hook is accomplishod using a retrectable 6-inch-dlameter A181 4340 heat-treated pln. The cask trunnions are engaged by the yoke J-hooks. The yoke cross-members hold four cables which are used to remore the oask closure head.

The entire atructure, except for the llfting points, is pelnted for corrosion protectlon. All Iitting pins and hooks are periodlcally nondestructlvely teated for Internel and surfeco flewa. All components of the standard lifting yoke have a minimum atety factor of 3 on static and dynamic loads in compliance whth Federat requirements.

At some seactor aites, the NRC will require a redundant lifiling yoke (Flgures 7 and b) to be employed with a redundent crane as acditional protection agelnst cask-ciop ecoidents. General Ejoctrlo can furnish s redundent yoke whith meets the requicements of NUREG-0612 and which accommodates most redundant crane concepts. As shown in Figure 7, the primery yoke, (Item 1) engeges the cask trunnions (Itean 2) in the same manner as the standard lifting yoke. Once the cask is vertlcal, the secondary yoke arms (Item 3) are extended from their retracted position and coupied to the fixed arms (Item 5) of a supporting credle (Item 6) which is bolted onto the cask's lower Impacting ring assembly at the etoctor aite. Movernent of the secondary yolke arms is accom. phished by a teaveling biock on an air motor driven power scrow. As with the standard lifting yoke, both portions of the redundant ifiting yoke have a safety tactor of 3 on static and dynamic loads.

\section{SAFETY ANALYSIS ANO UCENSING REQUIREMENTS}

\section{IF-MOO LLCENESNE STATUS}

The IF-300 cask design has received full Nuelear Regulatory Commission (NRC) and Depertment of Transportation approvals. NFC Certificate of Compllance No. 8001 was issued for the IF-300 in 1973. This CertifIcats of Compliance epplies to all cesks of the IF.300 design and currently permits itradiated fuel shipments, by epeciflcally registered cask ueers, in the dry mode. 


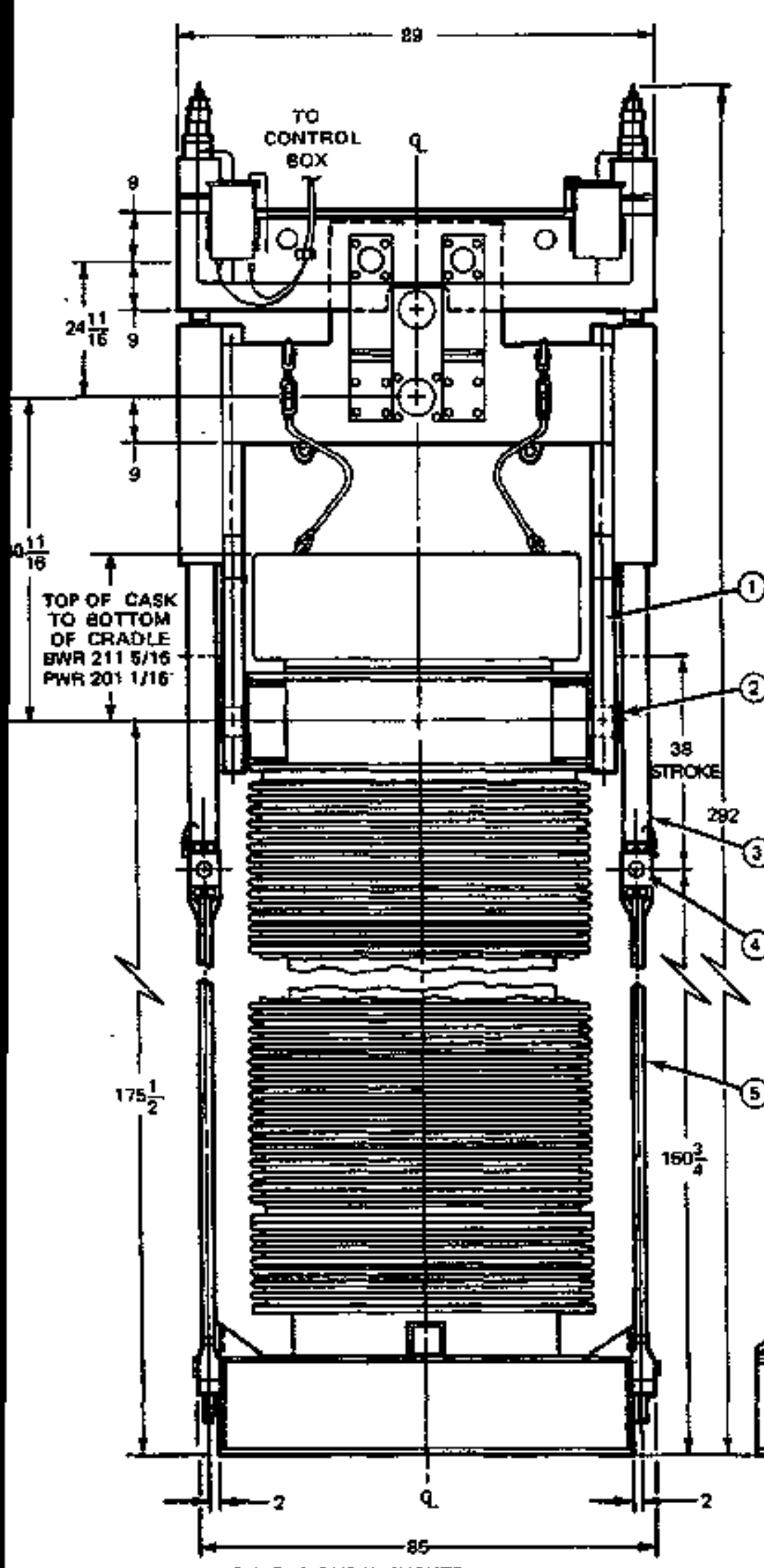

MOTE: ALL OIMENSIONS IN INCHES

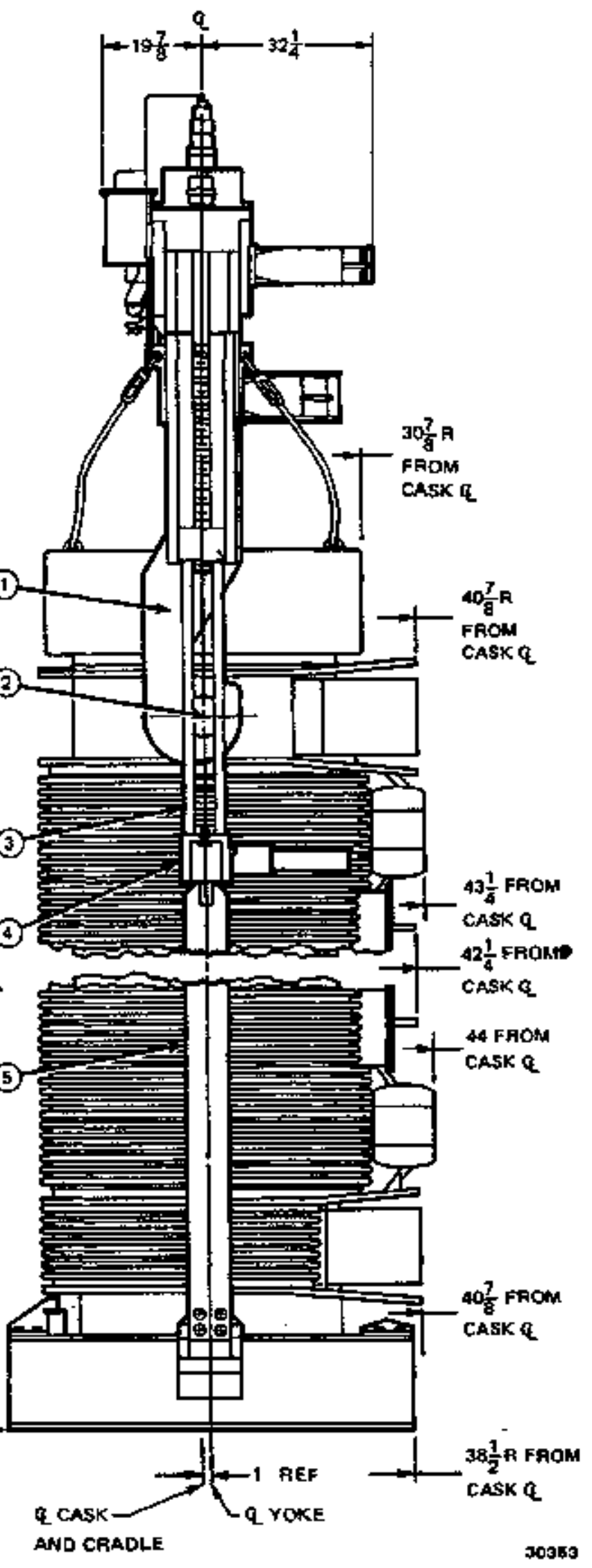

30353

Figure 7. Whiting Amangentent of Fedundent Yoks Assombly 


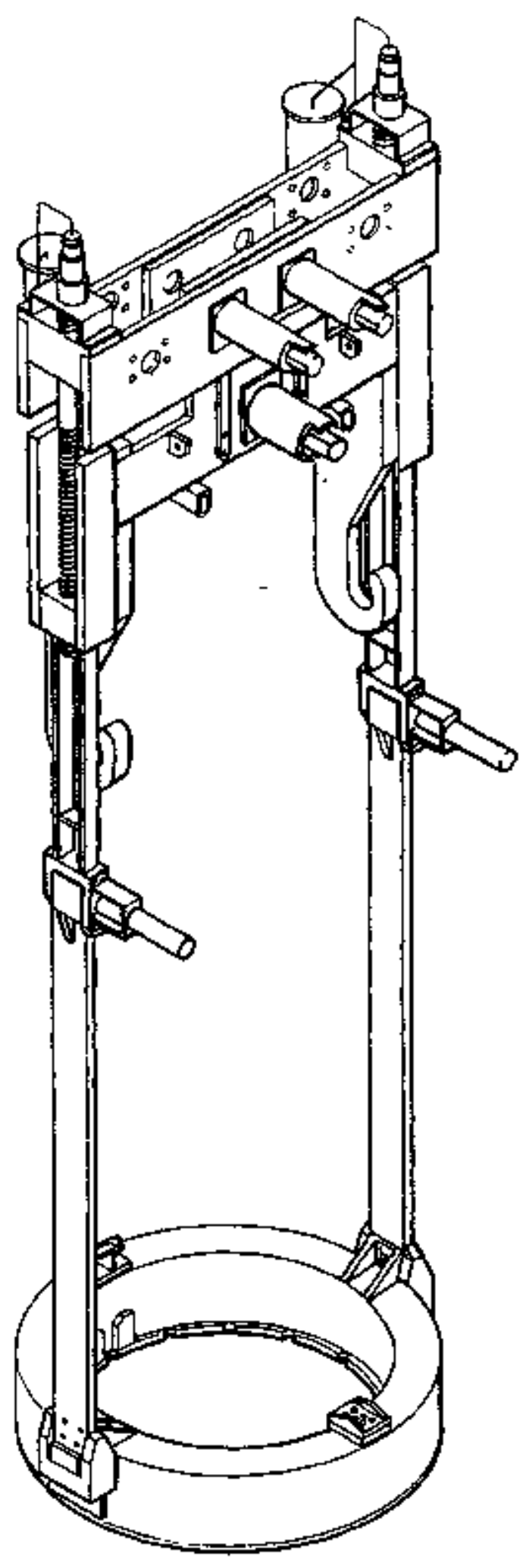

Figure 8. Isometric of the Redundant Yoke 


\section{LPCENSING PROCEDUAES}

Containers used for shtpping radloactive material currently undergo a license appraisal in the same con. text as that essuclated with nuclear reactors. The cask design is evaluated against the criteria spectited by regulatory requirements and conditions governing transportation of irradiated material, as oromulgated by the Nuciear Regulatory Commission and the U.S. Department of Transportation (DOT).

After a thorough siudy encompessing cask design and postulated usage, the cask supplier submits a Safety Analysis Feport. Thls document contalns: (1) a comprefhenstre design descriptton of the cask equipment; (2) repokts of associated structural, thermal, and criticality analyses; and (3) discussions of proposed cask contents, compliance with gafety regulations, and operation, maintenance, and quality assurance plans. Using this document, the NRC performs as evaluat on of the cask design as to ils adequacy for use in making shipments of itfadiated malerial; the NAC pertorms this evaluation for the DOT as wesl as Ior itself. After completion of the evaluatlon and a determination of cask acceptability in meeting regufatory requirements, the NAC iastans a Car. tlflcate of Compllance authorking the proposed cask contents and permitiling ine litensee to deliver the losded cask to a carsiar for transport.

\section{DESHEN CONDITIONS}

The regulatione specify both nomal and accident conditions egelnst which the radioective material packaging design must be evaluated. Theee conditions are intended to assure that the package has the requieite inegrity to meet all conditions whtich may conceivably be encountered during the courte of transporta. tion. The norms sthipping conditions requirs that the package be able to withatand tomperatures ranging from $-40^{\circ} \mathrm{F}$ to $+130^{\circ} \mathrm{F}$ and wbrattons, shocks, and weting Incldent to normal transport. In addition, the packeges are required to withstand specifled aceident conditions with a minimum relesse of radioactivity. The acoident conditione for which the package must be designed include the following sequence; a sa-foot free falt onto a

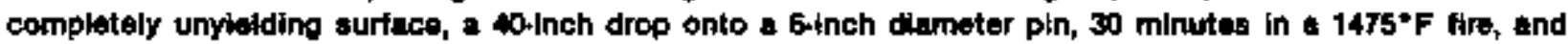
8 hours Immersion in 3 teet of water.

It is unlikely that the casks will experience conditions in transport as sovere as those imposed by the to CFR Part 71 requirements and, in ary event, conditions far mores severe than those would be cequited to result in a substantial breach of a cask. Funther, since the cask destion is evaluated by applying these conditions to the casks In sequence, the margin of conservatiem is increased. II Is highly improbable that a cask would be subjected to an event as severe af even one of these conditions, let alone all four. The conditions specitied by 10 CFR Part 79 and the caltulated results for the IF. 300 cask are described below.

\section{Thirtyfoot Fres fall}

The ahipping cask is tequlired to wlthatend a 30-100t free fall onto a compielety unyleiding surface. in this analysis, the 30-fool drop of the cask inwolved consideration of ten different ofientations - fouf vertical and six horizontal. The actident analysis also includes several parts: (1) the cask cavity as a pressure vessel: (2) the cask as a structure; and (3) the cask contenta.

The cask body undergoes severe loeding in all of the 30-foot drop orientations. There is a slight flange ylelding in the comer drop and slitht outer shell ylelding in the side drop orlentations. However, the cask re mains sealed whth no redtetlon in heary metal shletding. The fuat and fuel baskets also undergo severe loadling in the postulated drop accident and some yielding will occur. However, trextent of yiolding is limited by the short duration of the impact and the confinement of the carlity walts. Based on vitimate strength, no tuel or basket fallurea occur in the accident anstyais. 
The components which mitigate the vertically oriented drop effects are the impact fins which profrude from the cask ends and side. The structures deform an impact in a predictable manner and linit the forces transmitled to the cask body and contents. Protection from horlzontally oriented drops ls provided tyy side impact rings, and in the case of the valve boxes, rectangular fins. The cesk body is encircled by four thick stegl rings whtch form the primary impact protection. These rings tunction in a manner simtlar to the end flns in that they deform under tmpact and limit the loads imposed on the cask body.

\section{Forty-inch Puneture}

The 40+Inct puncture analysis requires that the cask be dropped from a height of $\boldsymbol{\omega}$ Inches, with the center of gravity directly above the point of impact, onto a Ginch diameter pin of suffeient length to punchlsie the contadner. The formule for analysis ot this condition was coveloped at Oak Riope National Laboratories and other places based on extenswe testing of steel and had shippino casks. In regard to the felationship of this enalysis to the transportation ervirontrend, It was originally intended that the 6-Inch diameter pin would approxImate that of the end of a rail lor rati transportation accidents.

fl should be noted that the casks are required to pass the puncture without rupture of even the outer sthell. Generally, there ts a heavy outer shell backed up by several inches of shielding materlal folkowed by an inner steel ahelj; thus, a wide margin exists between the dzmace that the cask would sustaln as a result of the re quined puncture topt and that which would be requited lo rupture the inner vessel such that there could be dispersal of the radioacthe contenls.

\section{Thloty Minutio Flk}

The cask must be degloned to withstand \& 30-minute exposure to a uniform hest flux environment correaponding to a thermal emissivity of 0.9 at a temperature of 1475 . $f$. This requiremont is simtiar to the cask being completely surrounded by a fire resulting from the open burning of petroleum such es diesel or jet fuet. In actuallity, the cask would moat lkely bo lying on the ground nearer the cooter part of the flames such that it wotid not be entlrely surrounded by the tire. Furthermore, while there may be individuat flame temperatures higher then the proposed $1475^{\circ} \mathrm{F}$, average flame lemperatures would not exceed this value.

The analyabs shows that the neutron shielding containirent structure remaine In plsce and acts as a thermil radlation barzier, thus liniting the heat transmlesion into the inner cavity. Throughout and subseosent to the fire, there is no fuel foiture or radkation releate.

\section{EXPERIENCE}

\section{CASK FABAICATION}

As of 1963, four IF,300 casks and associated peripheral equipment have been labricated under General Electric dlection and placed in service. The casks form an important experience base for as sessing design ade quacy, tabricafion lead times, component costs, and vendor capabilities.

\section{FUEL SHIPMENTS}

General Electric Company, Moris Operation, has received hundreds of Irradiated fuel shipments by both truck and rail. Mortis personnel have also worked closely with electric utilłties engaged in irfadiated fuet movemenis, using the IF.300 cask and others. The result of this is a signiflcant experience base in irradiated fuel transporation systen operations. The capabilties for logistical studles, Itcensing, carrier interfacing. train|ng. maintenance, and fiedd services have been developed by General Electric and can be made avatiabla in support ot the IF-300 cask. 


\section{TRANSPORTATION SUPPORT SEAVICES}

\section{SITE FACALITIES}

Pilor to the Inttation of any Irradiated fuel shlpping campalgn, it is assential that a thorowh revlew of plant faclitiles be conducted to assure compatibillty with the Inlended shipping cask. Many exlsting reactor buildings were designed prior to the time that the final wetghts, dimensions, and operational reouirements of Large, modern atpping cosks were detemined. As a result, interfarences, tlfting limitations, or needs tor additional plant tacilitles heve often been identJfled. SInce the time requjred to accomplish slgniflcant plant modifi. cations can be long, it Is important that a thorough revlew to identify such needs be conducted at an early date. Ceneral Elentric personnel experlenced in cesk handling can assist utility persconned in site survoys and assessment of apecific reactor plant facilities where appropriate.

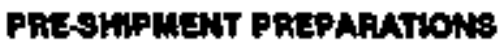

Once a cagk is selected and a shipment dalo is establishod, it is tmportant to make a dotermination of the specific tools, proctodures, and equipment required for each cask handing operation. If 300 Transportation 5yotem operating manuals tumbahed by GE can assist plant personnel in this dotermination. Adoquatio ad vanced proputation tan prevent coutly dalays and operating efrors.

\section{PERSONNEL TRANAME}

Cencel Electric will provide tralning of plant personnel inwolwed in cask handling operations during tirst Lse of an IF-300 oask and as needed tor later ahipmants. In General Electrk's viow, such tralning ba an Iraportant

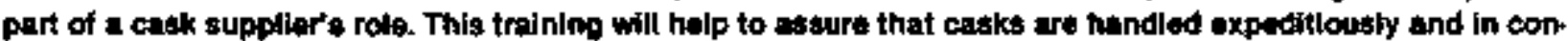
formanow with govertmental reguldtions and industry safety practices. Detalied operating and mainlenance manuaba for the IF-300 Irradiated Fual Tranaportatlon Syatem are walfable to supplement the tralfing program.

\section{SU:MARY}

The IF s00 Transportatlot System combines the proven economy of a hiph paylogd, multibundle cask with orent thexlbility. The capability of shlpping both high exposure BwA and PwR full vie alther rall or over. weigmt truck permits the IF-300 to serwe the aseds of most modem reactors.

The IF-300 ls a product of an experierced nuclear materlats transportation organtzation, responsibte for

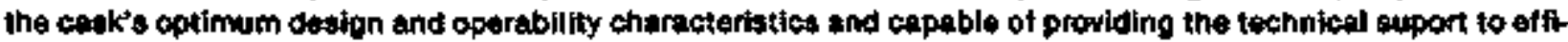
clently meat the utility industry o needs. 
NUCLEAR ENERGY BUSINESS OPERATIONS - GENERAL ELECTRIC COMPANY SAN JOSE, CALIFORNIA \$ 5126

GENERALG ELETRIC

TECHNICAL INFORMATION EXCHANGE JIfLE PAGE

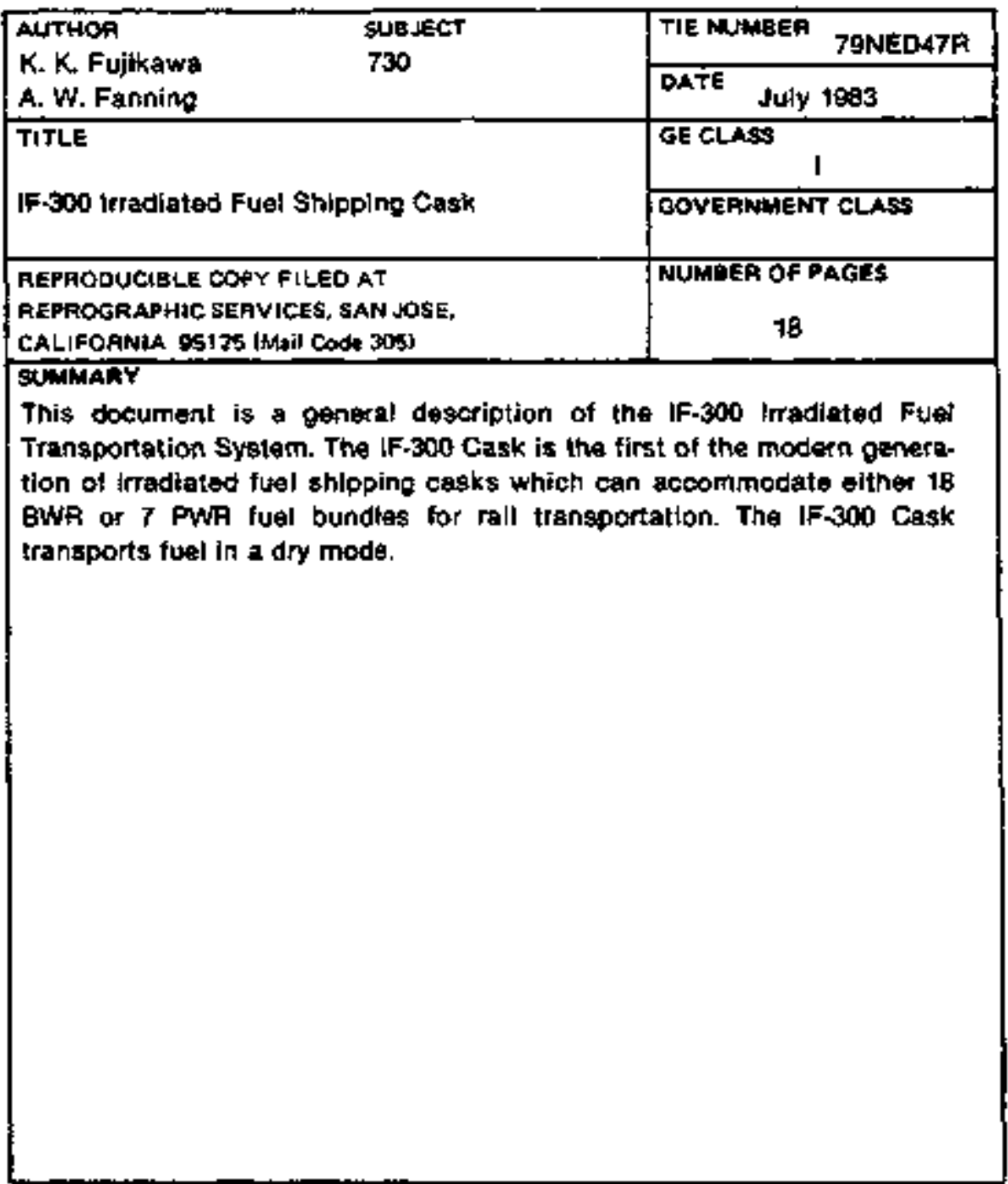

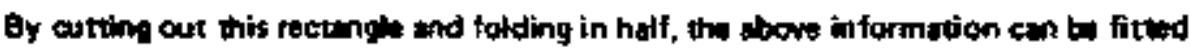
into $*$ stenderd end file.

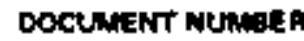
NEDO-10864C

INFORMATION PREFARED FOA General Electric Co.

secTion GEUMCO

BNILOHG MHD ROON NUHEER

995. 1806 MAIL CODE $\$ 56$ 


\section{Appendix E-2}

\section{BR 100 Design Information}


DOE/ID/12701-1 Ex.sum.

\section{Preliminary Design Report Executive Summary}

\section{Babcock and Wilcox BR-100 Cask}

May 1990

Prepared For

U.S. Department of Energy

Office of Civilian Radioactive Waste Management Contract \# DE-AC07-88ID12701

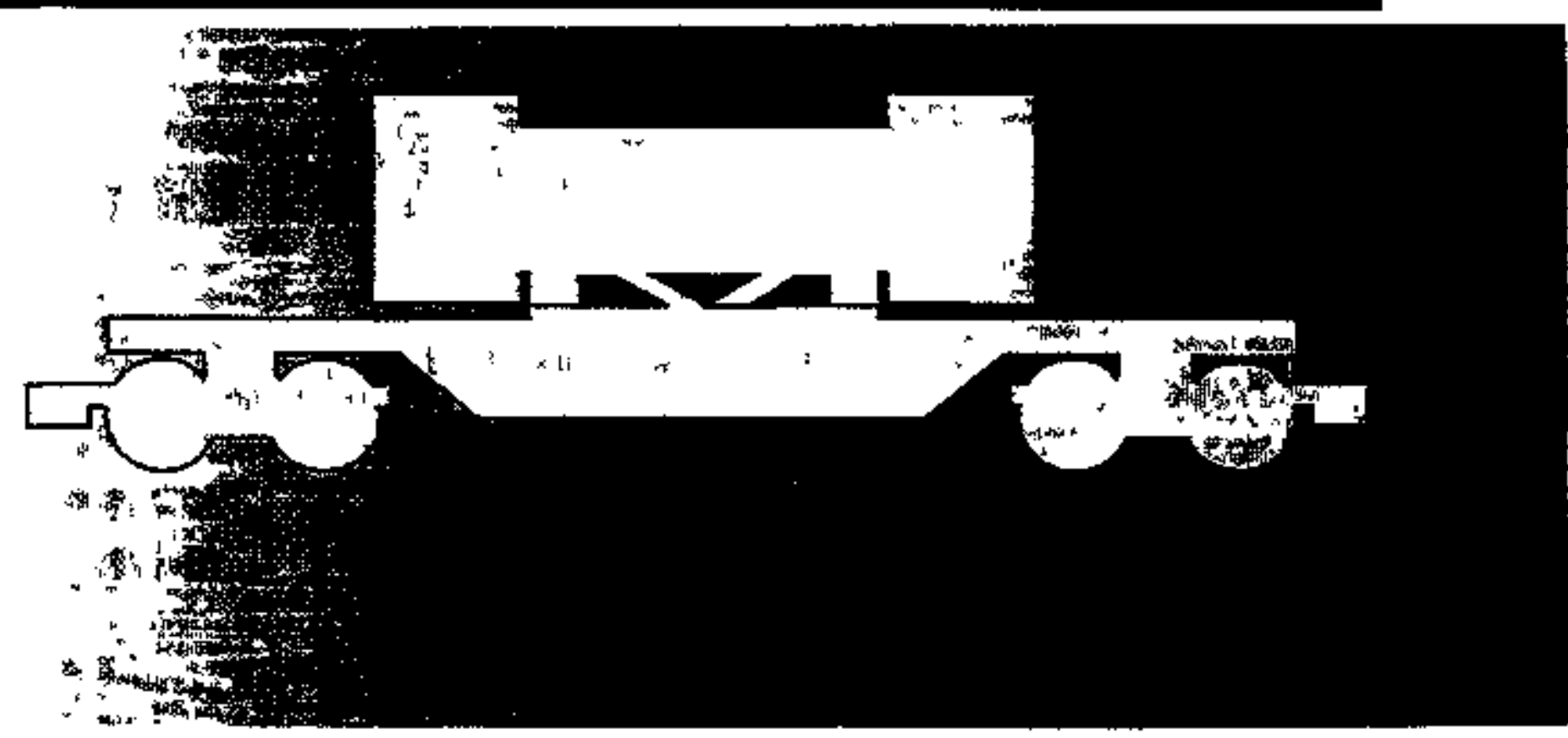


This report has bean repactuced difectly from the best trailable copy

Awatable to DOE and DOE conuactors from the

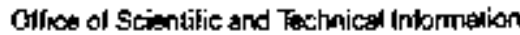

P.O. Box 62

Quak flidge, TN 378s?

Priceg axpilaty froct

1615) 676-8401, FI5 626-8401

Awaitable to the public ftom ithe

Nationed Techincal hiformation Service

U.S. Department of Commerce

5285 Fort Royal Rd.

Springfield, VA 22161

Prices: Printed Copy AO2

Mictolich A01

\section{DISCLAIMER}

This book wes preparted as an account of work sponsored by an agency of the Unitud Slates Government. Naither the United State Gowernment ner ary egency thareot. nor any of their enplopless. makes any warranty, expriss or inpliad, or assumes any

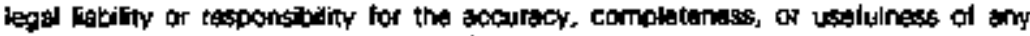
information, aparatus, producl or process disclosed, pr reprobents that its use would mot intringe privaledy ommed rights. Feterences herein 10 ary specific commerclal producl, proseses, of ervike by trade name, trademank, mamulacturet, of oiherwits. does not necessarily constituts or imply its endorsement, recornenendation, or fawcring by the binired States Govemment $\alpha$ any agency thercof. The wiews and opinions of euthors expressed herpin do nol necessarily slate or refilect those of the Uniled Sters Government or sny agency thereof. 
DOEAD/2701-1 Ex. sum.

Distribution Cetegoty: UC-880

\title{
PRELIMINARY DESIGN REPORT EXECUTIVE SUMMARY
}

\author{
Babcock and Wilcox \\ BR-100 Cask
}

Published May 1990

\author{
Bew Fual Coinpary \\ P. O. Box $10.0 \% 5$ \\ Lynchbung, Vh 24506
}

Propurad for the

U8. Depectment of Enwey

IWho Operefiond Otilo

Under DOE Contract Na. DE-ACO7-881012701 



\section{CONTENTS}

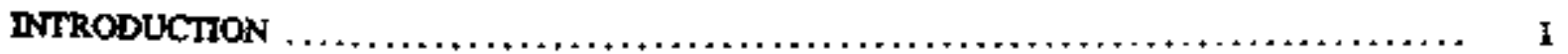

CONTAIRER DESCRIPTRON $, \ldots \ldots \ldots+\ldots \ldots \ldots \ldots \ldots \ldots \ldots \ldots \ldots \ldots+\ldots \ldots \ldots \ldots \ldots, 1$

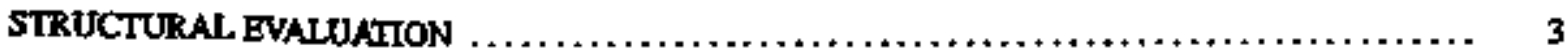

THERRMAL EVALUATION $\ldots \ldots \ldots \ldots \ldots \ldots+\ldots \ldots \ldots \ldots \ldots \ldots \ldots \ldots \ldots \ldots \ldots \ldots \ldots+\ldots, 5$

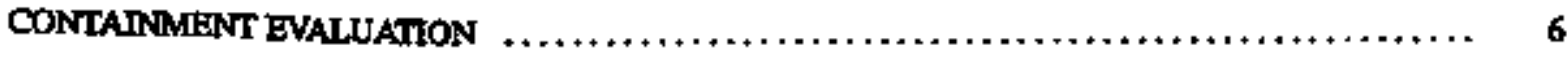

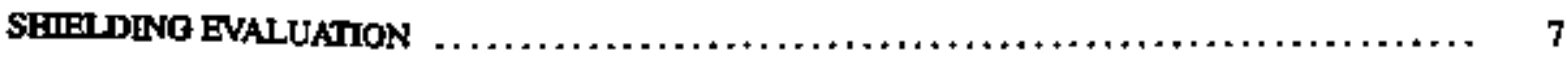

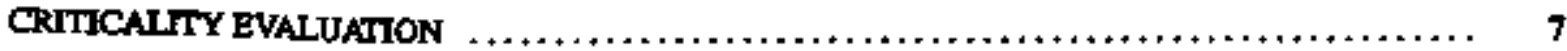

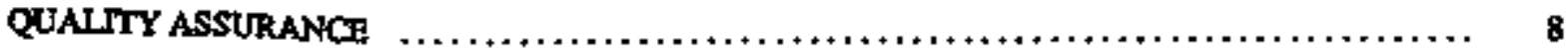

CERTIFICATION ISSUES $\ldots \ldots \ldots \ldots \ldots \ldots \ldots \ldots \ldots \ldots \ldots \ldots \ldots \ldots \ldots \ldots \ldots \ldots \ldots \ldots \ldots \ldots, \ldots, g$

TRANSPORTER SYSTEM $\ldots \ldots \ldots \ldots \ldots \ldots \ldots \ldots \ldots \ldots \ldots \ldots \ldots \ldots \ldots \ldots \ldots \ldots \ldots \ldots \ldots, 10$

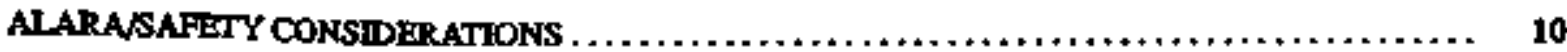

RELIABIITY AND MANTAINABILITY $\ldots \ldots \ldots \ldots \ldots \ldots \ldots \ldots \ldots \ldots \ldots \ldots \ldots \ldots \ldots+\ldots \ldots, \quad$ II

FIGURES

1. B\&W BR-100 rilbarge cask $\ldots \ldots \ldots \ldots \ldots \ldots \ldots \ldots \ldots \ldots \ldots \ldots \ldots \ldots \ldots \ldots \ldots \ldots, 2$

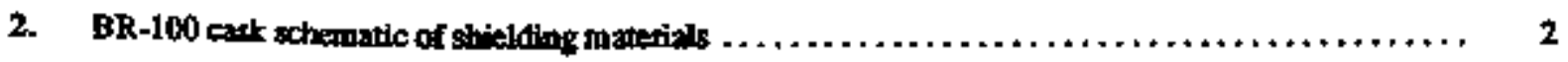

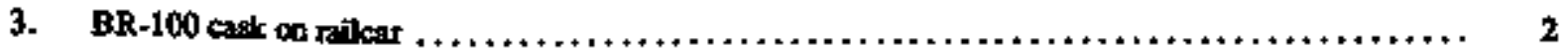

\section{TABLES}

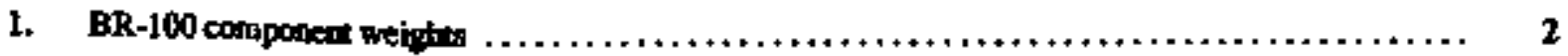

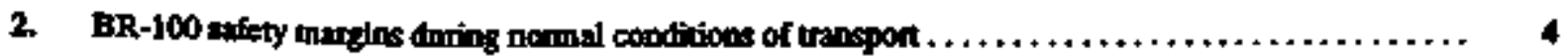

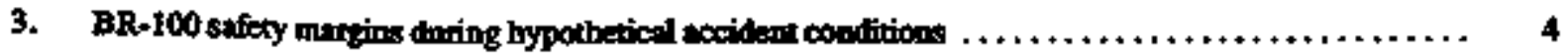

4. Baselibe bernal performace sumening $\ldots \ldots \ldots \ldots \ldots \ldots \ldots \ldots \ldots \ldots \ldots \ldots \ldots \ldots \ldots$ s

5. PWR dose roter for nomplal opersting cooditions $\ldots \ldots \ldots \ldots \ldots \ldots \ldots \ldots \ldots \ldots \ldots \ldots \ldots$ \&

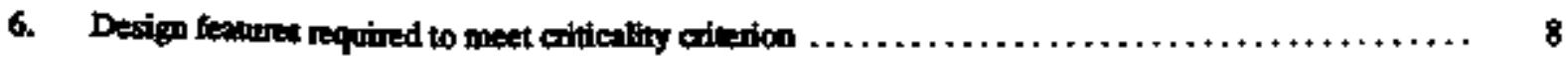

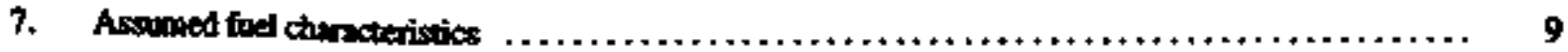




\section{PRELIMINARY DESIGN REPORT EXECUTIVE SUMMARY}

\section{BABCOCK AND WILCOX BR-100 CASK}

\section{INTRODUCTION}

The Nucleat Whate Poticy Act of 1982 , as amended, mede the Ofice of Civilian Redionctive Waste Mro. aftment (OCRWM) of the U.S. Deptrinent of Energy (DOE) respousthis for managing the progran for the permanem disposal of spent nuclear foel frow commercial power plants and high-level radionetive waste fropu asticand defende activities.

Trespoctation casks will contribute to the safety of

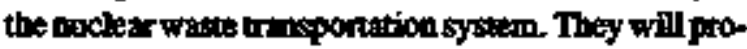
tect the public and trasportotion woikens from pevential exposure to radincion during nondal trenspostation activities and if an ectiden occurs. This protection is provided throuth the use of a new conention of casts desioned and constnoted according to regulations es- tollisted by the U.S. Nowlear Regalatary Conomission (NRC).

The OCRWM Cast Systems Development Program is designing a vertiety of casts to safely inospont todio-

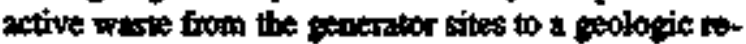
pository or a monitored retritevable storage facility. Five contracts have been awarded: thee to develop

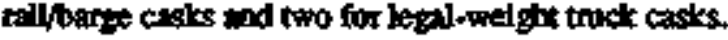

By December 1989, all five cask coutractors bad subinitted prelininary designs to be OCRWM The desiges have been reviewed by a Tectuical Review Gmop composed of mational experts in cast developmeat ares. This Execotive Summiny describes the mitor features of the B\&W BR-100 milbarge sped foel cask desigen

\section{CONTAINER DESCRIPTION}

The Babcock \& Wilcox BR-100 stipping cortainer sybten is strom to Figure 1. The system consists of the coutniner, impact limiless, stid, raikar asd ancilhiry expipuent The cavity within the cylindrical contrines boids a renorable fuet basinet the accommodites ei-

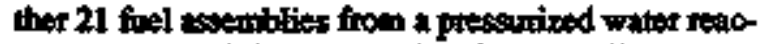
tor (PWR) ot 52 foel bemblies from a boiling wors

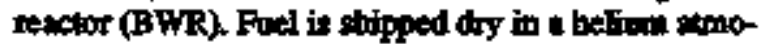
splede to eshence safety during transport.

The conninef, with inpact limiters, has an overill length of $21 \mathrm{ft}$, dimmeter of $10.5 \mathrm{ft}$, and weigts 102 tons. Culvolnted or extimand wiphts for the BR-100 contriner systen (both PWR and BWR configurttions) are given in Thble 1.

The BR-100 thipping corkinge is transpotted borzontally io a thipping Etid compatible with rail or berge shipment ontainer loeting ant viloading opentions are perfomed with the BR-100 continer in 3 vertical oxtistation. The closure bid end is deffmed as the top with the conepiner verticall, and is the for wird exd when borizon onl Trun mons bolted to the conteier body te powidod for tifing and irnding operations, imcluding rotation between vertical and horimatel positions.

A recially designed reilcer will be used to ur asport the BR-160 continine. A persondel bytiter is used to proet wonters and the public from bent or radiolog. ictel exposine. Plactiols and shipping information are ispinyed in accondence with relevart atote and fetenl regulations.

The batic stncthose of the BR-100 couba inet consists of a mniti-will body and a bolted clogure bid The conbiner body connists of tro concedtric trialese steel cyitinders welided at the top to the forjed stoinless stect boling finge and to separate forged plakes on the bottom. Layeirs of borated cement and lead separate the theel cylinders providing neutron and ganmo stielde. The hiphestenght stanless stod closune bid asos two elastoner O-ting gets to tocomplish coutsinned. The bolks used to atach the lid to the cortainer body are mide of a high-sirength nickel allog.

Inpact limiless, consisting of balpa and rodwood eq cened in a Kevler /epaxy conposine, ane attected to exch ond of the conteinex. These materials bave been 


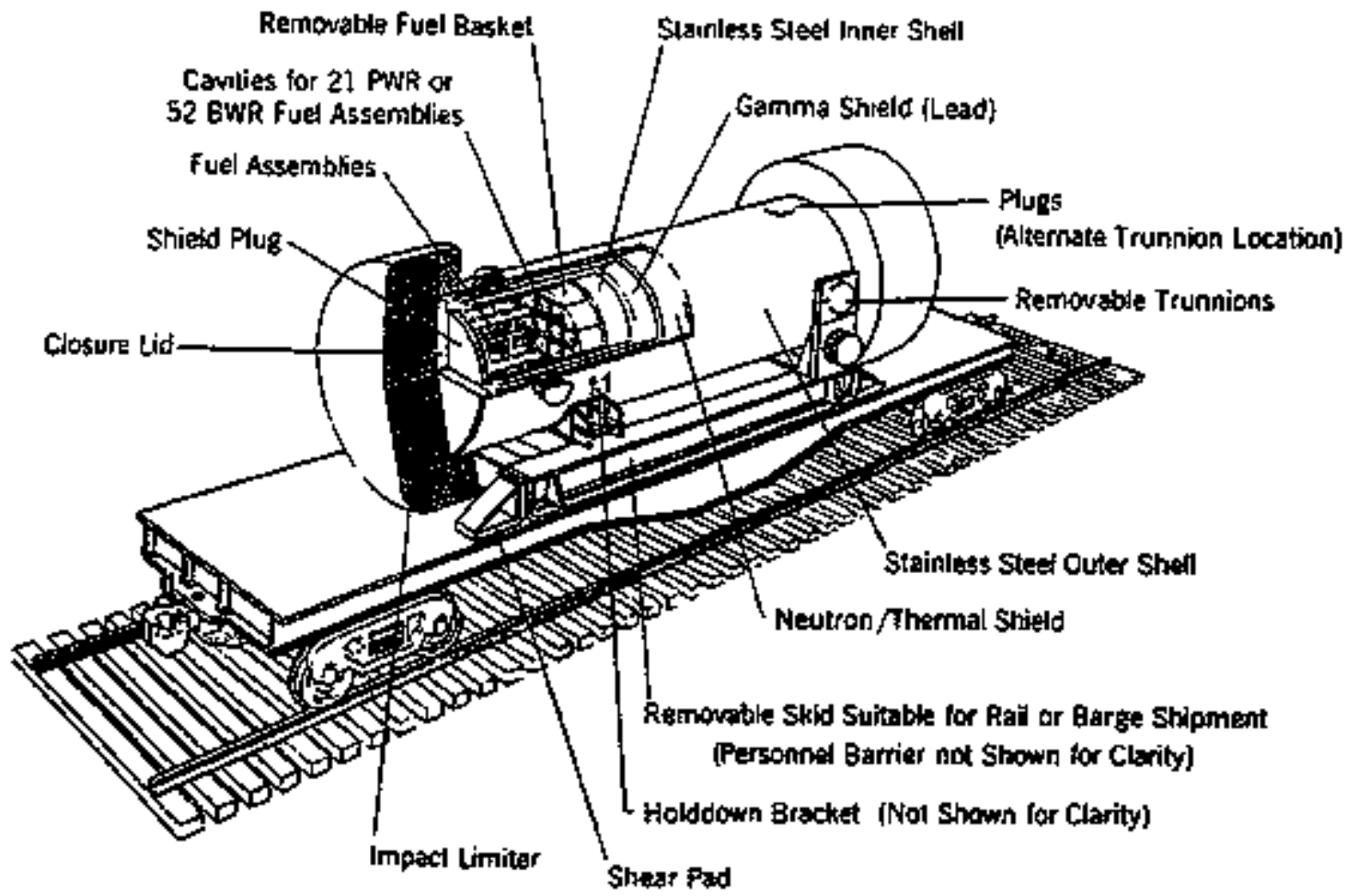

Flgure 1. B\&W BR-100 rail barge catc.

selected for their eoergy-absorting atilities, ultimately redocing unpact loeds on the coutainer during an axi. denc. The fuel bastets are assemblies of individnel foel storage colls mate priminily of anodized iluminam for structural and thermal reasons and a boroo-aluminum steet material for criticality control A seprate stield Fing of lead encosed in strinless gleel is locited be tween the heli and the closure lix.

Table 1. BR-100 component weights (lb)

\begin{tabular}{|c|c|c|c|c|}
\hline \multirow[b]{2}{*}{ Componemt } & \multicolumn{2}{|c|}{$\begin{array}{l}\text { Pool Ltfintis } \\
\text { Comfigntaion }\end{array}$} & \multicolumn{2}{|c|}{$\begin{array}{l}\text { Transpoination } \\
\text { Configlation }\end{array}$} \\
\hline & PWR & $\mathbf{B W R}$ & PWR & B*:R \\
\hline 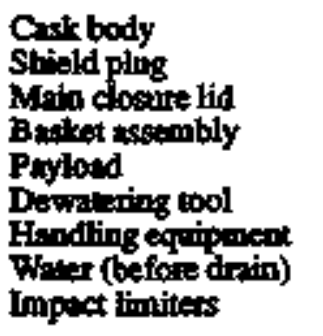 & $\begin{array}{r}139,000 \\
5,200 \\
-000 \\
9,000 \\
32,800 \\
1,000 \\
2,500 \\
10,000 \\
-\end{array}$ & $\begin{array}{r}139,900 \\
5,200 \\
= \\
10,000 \\
33,000 \\
1,000 \\
2, \$ 00 \\
8, \$ 00 \\
=\end{array}$ & $\begin{array}{r}139,000 \\
\mathbf{5 , 2 0 0} \\
7,700 \\
9,000 \\
32,800 \\
= \\
= \\
8,400\end{array}$ & $\begin{array}{r}139,000 \\
5,200 \\
7,700 \\
10,000 \\
33,800 \\
= \\
= \\
8,000\end{array}$ \\
\hline $\begin{array}{l}\text { Padtue tod } \\
\text { Condens }\end{array}$ & 199,500 & 200,000 & 201,700 & 203,700 \\
\hline $\begin{array}{l}\text { Roilcar } \\
\text { Stid } \\
\text { Pensonoel Butiot }\end{array}$ & $\bar{m}$ & $\ddot{m}$ & $\begin{array}{r}45,000 \\
11,500 \\
500\end{array}$ & $\begin{array}{r}45,000 \\
11,500 \\
500\end{array}$ \\
\hline Grous Whicle Whipt: & ــ & ـ. & 258,700 & 260,700 \\
\hline
\end{tabular}


The total empty weigte of the BR-190 contpiner is $168,900 \mathrm{lb}$ with the PWR bastet or $169,900 \mathrm{lb}$ with the BWR basket. Its conresponding londed weight can range op o 201,700 lo for the heaviest PWR payload of 203,700 lb for the heaviest BWR paylosd

The BR-100 dexizn finctions over a full range of expected envimameats withont the we of forced coot ing of ary sappinemental equipment of power sorites. Both for wormal conditions of opertition end hypothetical accident conditions, per 10 CFR 71, it will s.tisfy its goils of conemisment, stielfing and prevention of fuel criticality.

The BR-109 design has several featumes common to other cortainers that have been certified and used for many years. The oses of stainless steel as a contsinment mucailal, bet os a zamma shield, and balsy' redwood for impact thsorption, for example, have been proven to be reliable and economictal. The BR-100 design has comtined these eficicir fitures with severpl insoymive iteos to optinize contuiner performance in safety, cperations, and cost Tho most significall of these innovetions ace: (1) the ase of a bonued cement/copper fin army as a combinution nettron shield and "thermal switch," (2) the use of Keviry to contin the wood of the inpact limiter, (3) the foel cell bestet constrostion tectanigue, and (4) the we of a two-piect lidfshield plug cloorie.

The buracd cemert/oopper fin feature is a potenced syctern previousty oentified and used in Frace for sim. ilar contsiness. The borton tod wher in the cenent act as an excellept Detutron absorber, with no sigrificat decresse í effectiveness even after hypothotical accident cooditions. The copper fins allow beat geocraved by the fuel payload to be contucted to the outer trin of the coobsiner and then to the eavioument, but a layer of cemest between the firs and the onter stin debyIrates if the best coming from the exrironement is too intense, as in the case of a themal trensitent. The partial dethydration ingulates the lead gamma stield and the fuel from any detrimeatol effocts of exiernal beet. bot allows the beat flow from the fuel to resume atter the themal transieot is over,

The use of Keviaro to contsin the balsa and redwood of the impact limiter allows the weiste of the im. pact linaiter to be significantly reduced withont macrificine stuctaril integrity. Kevlaro is six times stronger then steel per anti welight. Sooping compression tes have demondtrited the energy absotting so. perionity of the wood/Keviente comblnetion Specitic wood and Xevind selected for use in finsl desion will be characterized to establish mechanical property variability.

The two-pisece clowere syttell cotsists of a shield plog pluced in the coutsions after foel loating and a closore fid beliced on aftar the cootainet is removed from the resetor storige pool. The seperate stield plug slfows quict drising of the container before it is lifted from the storage pool by piessurizing the container to $3 \mathrm{~atm}$. of mitrogen or dry ais. The two pinece system then allows the contmine to be lifted to a woit stetion where the closure bid con be quictsy instrilled ard re. maining operations performed, thereby reducing wattor exposurt.

\section{STRUCTURAL EVALUATION}

The BR-100 stipping containor is dexizand to med all applicable regulalory criteria for nomal trinspont and hypotheticel sccident contritions. These cooditions tre desctibed in 10 CFR 71 (1986 Revision), "PuctagIne and Trenpotation of Rutiosetive Mandiel." Design criteria wod louding combinations ate thes fron NRC Repultory Gaides 7.6, and 7.84, tespectively, to sseess ptructuril integdty based on allowable dress

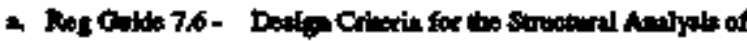

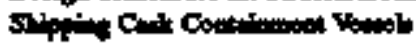

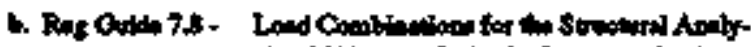

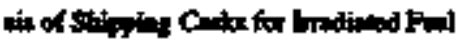

linits provided in Section III of the ASMB Boiler a Pressure Vessel Code. The methods and material propexties requined for use by these colles ine conservative Duing the prefiminting desipg phase, onily major components of the container were analyzed; all were thown to prowide mangins of sofety that excoed the requintinesats.

Major continer conporeuts were anslyzed duping prelimintry desigen to itteotify mangins of metety for botb nornal operation and bypotbetical scoident conditions. Results are shown in Tables 2 and 3 . respectively. The lotdings antlyzed were the maximom tor ench condtion and, in most cases, counot 
occur simniteneousty. The stresses obtrined by these methods are the highest to be expected over the life of toe couttainer.

Normal condtitions of transport, per 10 CFR 71, ane:

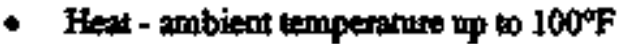

- Cold - anbieat ienperature down to-40\%

- Redoced external pressure to 3.5 psia

- Increased exterral pressire to 20 psia

- Vibration incideots' to transportasion

- Water sproy simulating 2 in $h$ of rain for $1 \mathrm{~h}$

- Free drop - $1 \mathrm{ft}$ onto noyielding borizontal surtace

- Penetration - impoct of the bemispherical end of a rertical stet cylinder 1.25.in dirmeter and reighing 13 tb dropped from a heigtt of $40 \mathrm{kn}$.
Tablo 2. BR-100 safecy margins duming aonnal conditions of trincport

\begin{tabular}{|c|c|c|}
\hline \multirow[b]{2}{*}{ Componitax } & \multicolumn{2}{|c|}{ 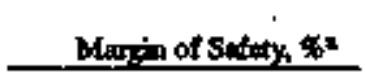 } \\
\hline & $\begin{array}{l}\text { Primary } \\
\text { Membriace } \\
\text { Temole }\end{array}$ & $\begin{array}{l}\text { Primary } \\
\text { Memibrane } \\
\text { Pug Beading }\end{array}$ \\
\hline 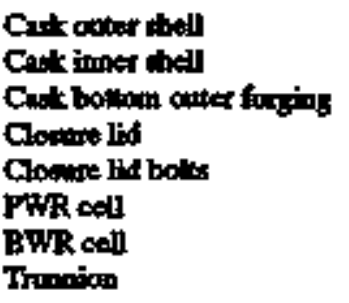 & $\begin{array}{r}>500 \\
262 \\
>500 \\
>\$ 00 \\
115 \\
\mathrm{~N} / \mathrm{A} \\
\mathrm{N} / \mathrm{A} \\
\mathrm{N} / \mathrm{A}\end{array}$ & $\begin{array}{c}73 \\
45 \\
15 \\
32 \\
1 / 4 \\
70 \\
82 \\
13\end{array}$ \\
\hline \multicolumn{3}{|c|}{ 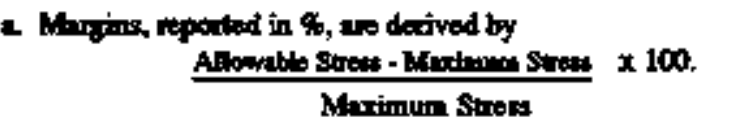 } \\
\hline
\end{tabular}

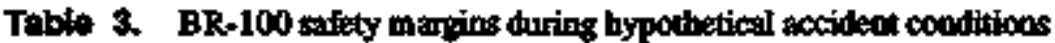

Marisin of Sutety, \%"

\begin{tabular}{|c|c|c|c|c|}
\hline & \multicolumn{2}{|c|}{ Primary Membrine } & \multirow[b]{2}{*}{$\begin{array}{l}\text { Primary Plus } \\
\text { Bendings }\end{array}$} & \multirow[b]{2}{*}{ Punctine } \\
\hline & Tensile & $\begin{array}{l}\text { Compressive } \\
\text { Bucteling }\end{array}$ & & \\
\hline $\begin{array}{l}\text { Cost outer shell } \\
\text { Cost irner shell } \\
\text { Cost bottom onser } \\
\text { forping }\end{array}$ & $\begin{array}{r}487 \\
\times 500 \\
491\end{array}$ & $\begin{array}{r}13 \\
393 \\
\text { N/A }\end{array}$ & $\begin{array}{l}7 \\
1 \\
6\end{array}$ & $\begin{array}{l}224 \\
31 \\
96\end{array}$ \\
\hline $\begin{array}{l}\text { Closuc id } \\
\text { Closine lid bols } \\
\text { PWR Cel! } \\
\text { BWR Cell }\end{array}$ & $\begin{array}{l}367 \\
106 \\
N / A \\
N / A\end{array}$ & $\begin{array}{l}N / A \\
N / A \\
61 \\
638\end{array}$ & $\begin{array}{c}1 \\
\mathbf{N} / \mathbf{A} \\
2 \\
9\end{array}$ & $\begin{array}{l}\text { N/A } \\
\text { N/A }\end{array}$ \\
\hline
\end{tabular}

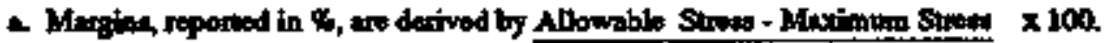



are:

Hypotbaticel acoident contitions, per 10 CFR 71,

- Fise trop - a 30-ft drop in the most damaging oriemation onto an myielding, horizonatal serfince

- Pexcute - $4 \mathbf{4 0}$ in-dup of the cortainer onto a 6-in. diameter mild seetl cylinder at laast 8-in. lone

- Thermal - exposure of the container for 30 min or longar to an exveloping environmext of $1475^{\circ} \mathrm{F}$

- Immerion - A watr bead of $656 \mathrm{ft}$.

During pertiminery derign, the structural integaty was evainated naing conservative palytical or empiricsl methods. Detailed andlytical methods will be employed for the final design. Also during fint design, testing of a quarter-ectle model and certin

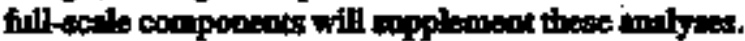

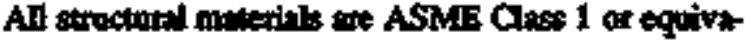
leat. For conservatism, the structinl stritagth of the lesd and cement layers of the shell are cot used, bot their weigtes are constdered in stintchinal analyses. The impect limiliers ane designed to ltmit the forces im- posed on the conthiner to 80 " 8 " drming side impact, ond 60 " $\mathrm{g}$ " for an end drop.

Finito element andysis tochniques are need extrafively to analyne stees distributions and deformetions in coptainer components. These techaigass ue computer codes that have been developed for specific upplicotions. All codes will be certified and bench. marted to known solntions before use. The codes used ans:

- ANSYS - a geoofal-purpose progran employing the state-of-the-art, finite-element technology appiticable to componert static ant dyunitic andysts

- PATRAN - A pre- and post-processing code weed to develop anslytical models for $f$ nite-element codes

- ABAQUS - A finite-dement cod- for geuser use in beth nonlineer and linear structural andysts. It is partictionily useful for panctune and inpact analysis

- IIAN - A BerW-code used in the cesign of the inpact liniters. It also predicts intpact angles for merimun eneres absorption.

\section{THERMAL EVALUATION}

The BR-100 design meets the formal requinements

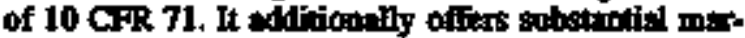
pins to establisbed matial temperture limiss set by anolysts, texing, and mond enginesing proctice. Th's

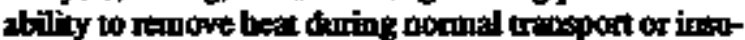

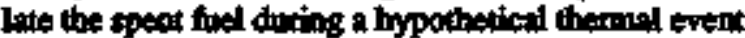
is eigniflcant in pasperving the inegrity of the contrinor and its contonts.

Themill linits estabtithed for the verions compo.

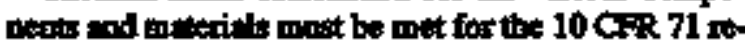
quivemer of a $100^{\circ} \mathrm{F}\left(38^{\circ} \mathrm{C}\right)$ doy with soln insolimion of $388 \mathrm{~W} / \mathrm{m}^{2}$ and a fuel paylood peocting tho maxi. mas best credible within the bouts of expected transpont cooditions. Calculations are made at the point of msarimum bean input to te BR-100 container.

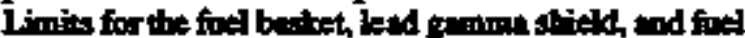
cludding must also be mex for the hypothetical thenmol event condtions.

The whing thetexist for the BR-100 decign are en-

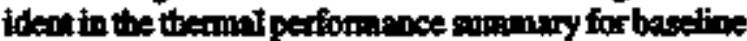
fuel shown in Thite 4.

The themall outpox of the fuel used to determine the nominal condition ienperenues is $12 \mathrm{~kW}$. The themal capactly of the BR-100 contsiner approaches $18 \mathrm{~kW}$ before any of the temperrine limits are neacted

Thble 4. Baseline themenal peformance summary

\begin{tabular}{|c|c|c|c|}
\hline Loxition & \multirow[t]{2}{*}{$\begin{array}{l}\text { Mininamom } \\
\text { Temperniture } \\
\text { Limits } \\
\left.{ }^{\circ} \mathrm{FP}^{\circ} \mathrm{C}\right) \\
\end{array}$} & \multicolumn{2}{|c|}{$\begin{array}{c}\text { Nomialb } \\
\text { Conditions: } \\
\text { ('F/PC) }\end{array}$} \\
\hline & & PWR & BWR \\
\hline 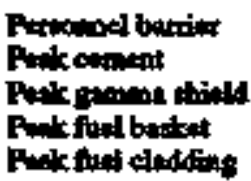 & $\begin{array}{l}180 / 62 * \\
250 / 121 * \\
620 / 327 \\
350 / 177 \\
600 / 561\end{array}$ & $\begin{array}{l}<16062 \\
210 \% 9 \\
21 / 102 \\
274135 \\
364185\end{array}$ & 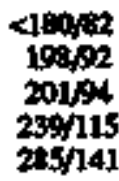 \\
\hline
\end{tabular}

Notes:

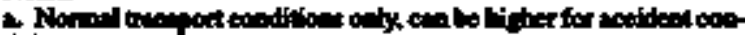
Ations.

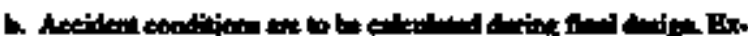

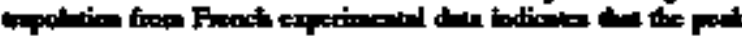

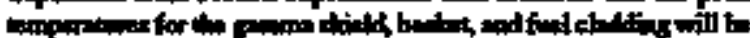

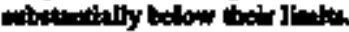


The inner and outer shefils of the BR-100 container body are subjected to different thermally induced pressure envinonowers during Dormal or accident events. For normal conditions, the outer shell is exposed to a pressire based on a combination of noncondensible gas and vapor presserre. The major contribution results from the motsture in the pement being dutven off as vapor at 8atumation pressure. At the cement temperature limit, $250^{\circ} \mathrm{F} 121^{\circ} \mathrm{C}$, this value comesponds to a sanoration pressure of 30 psig (0.21 MPa), substrintially be. kw the level that would canse sny structural concerns. The inder stell ander tondal conditions will function with in internat pressure less than mospheric. The Maxintum Nombal Operating Pressure (MNOP, as defined in 10 CFR 71) assomes all fuel rods ane ruparred and would result in an intems pressure less then 100 psig (0.69 MPa). Such an event is highty untikely but bes been used to estrbtist extremely conservative requirements. In adtition, a $50 \%$ maryin is used for pres. sure testing the contaimnent.

For bypothetical accident conditions, the woter shell experiecoes pressures developed in the same fashion as for the oxenal conditions with the following exception; the outer sbell bis strategically placed fusible plugs thes mekt at about $300^{\circ} \mathrm{F}\left(144^{\circ} \mathrm{C}\right)$, flus timiting the sampration pressure to iess than $60 \mathrm{psig}$ (0.40 MPa). The inner tell irternal pressures me estimated to be onty stightly above the 100 psig (0.69 MPa) predicted for MNOP conditions because of the mell merease in intemal temperotures. Those pressures ane well within design linvits for the shells.

The beat transtife relationships used during preliminary design are:

- A one-dimensicaal model to calculate beat transfer fbrough the container body

- The Wooten-Epstein relationshtp to generate peak spent foel clad temperatures

- Finito-elemens codes to calculate the two-dimeastional heat flow in the fuei basket.

Two computer codes wers thed to support themsal malysis during prelimínary design: PATRAN (briefly described onder STRUCTURAL EVALUATION) and PTHERMAL, which is a general-perpose thermal analytis program cempable of 1-, 2-, or 3-dimensional anglysis. This code calcolates conduction, convection,

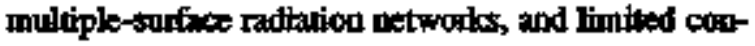
vection.

\section{CONTANMENT EVALUATION}

The BR 100 contaimment boundery is designed to meet regulatory release requinements for nomal trins. portation and hypothetical accident condifions. During pretimimary design, a structural evaluation of the main closure was considered sufficient for containtment evaluation, Criteria used were:

- No plastic deformation of the closure lid

- No yieid of clossme belts

- Conservation of compression chamatteristies of the elastoner seals.

The objective of a contoinment analysis is to demonstrate the design of the shipping contsinet for a lest-tight capacity as defined in ANSI N14.5. Howev. et, as results of DOE's ongoting sounce iem evalantion progran become avadlable, jeakage testieg requirements will be set to satisfy conotatnonent requinements of 10 CFR 71.51(a). The contninmeat vessel is an ASME Code Class 1 cotrponed with bighest Quality Assurence standards for unterials and construction. The materirils are compatible with both wet and bry to- viroumenes wod were selected to preveru chemical or galvanic efifocts leading to corrosion.

Theres are only two penetrations into the primary containment: one 3/8-in, and obe 1/2-in, quick-disconneat valve, both locteded in the closure lid. They are used for final drifoing of the container, vatum drying, pressurization with intert gas, piessure measutements, cavity gas analysis, and cavity colling. Cossure ts ensuned by 32 high-ettength bolts on the closure lid and $6 \mathrm{figh-gtrength}$ bolts on the penetrtion cover plate.

The contrinment evaluntion doring preliminnity desigo contidered the cold envirosment and the fise dopp for comal conditions of transport, and imonersion, free drop, panctoine, and themal conditions for the bypotbetical accidest.

In both cases, the fire drop providas the maximnm loading on the bolled of sane. No acherse effocts from either noimal of accident conditions are expected to inpact perfotmance of the contaimment. 


\section{SHIELDING EVALUATION}

Concentric layets of tead and borated cement encedpsolated between inter and outer shel shells ensorr ac. ceptable external dose rates for the BR-100. Lead provides the primary gromma-ridiation shielding and is arringed to minimize overnll weight of the corr.iner withour sactificing the shielding effoctiveness. A bo raned center was cheser to moderate and theorb nes. trons. Figure 2 shows materials, locations, and thickoesses of these elements.

Fuel characteristics used in the siolding malyses - were chosen to yield the moximum codible tadiation to ation. Material propenties wene chosen to minimize their shielding effectiveness, then parviding forther conservatism.

Gamman and nentron dose tates calculated during prebiminary design ate shown in Talle 5 and include neutuons and primary gammas originating from the fasl, and secondary gammas resulting from neutron copture in shielding matrifils. Maximum dose rote in the package surface is well below the $200 \mathrm{mrem} / \mathrm{hr}$ regulatory bimit, and the maximum dose rate it $2 \mathrm{~m}$ (6 ft) from the package does oot exceed the limit of 10 mirenthr.

Dose rates for BWR foel loading are abour $50 \%$ of those calcalated for PWR fuel. Tie ose of more dis. crete methods during final desigo shots reduce the predicted dose rats significamily and measured dose rtes are usually siggificandy lower thm precticted.

The dose rates for post-accident conditions ane catimaled to be only slightly higher than for normal opersting conditions, and they will be verified by testibi and analysis doring final desigo.

The following compatie codes were used to atimate dose rates:

- ORIGaN2 - calculakes the source from the fuel region consisting of neutron and gensend comporents from activation products, acti. aides, and fission products. Sources from strocturil components of the fuel assembly (primarily gamma radiation from decay of Co-60) were band calculled.

- ANINN BW - a one-dimensional fiscretz-orfinates trairsport code that sclves the Boltzmana transport expation for neotrons and/or gunmas. This code was ased to colcoilate ro. titil centerline dose rates and neutron dose rates at the eods of the conininer

- QAD-CGGP - a thre-dimerisiond point-kerDe code originally developed by Out Ridge National Laboratoty (as QAD-GP). This codte was used to estimate grmma dose rites from the fuel and $\mathrm{Co}_{0} 60$ in end filtings and apacer gridls of the foel.

\section{CRTICALTY EVALUATION}

Criticality control tor the BR-100 shipping contain$e r$ is maincsined below the regulatory linait, $k_{\max }$. 0.95 , by a conalimation of geometry, fixed potson, and

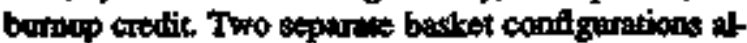
kw the cootainet to bold eistuer 21 PWR of 52 BWR intact foel assemblies. Each configanition repuires a different combination of design festares to meet the $k_{\text {max }}<0.95$ criberion 2 s shown in Table 6.

Ambris indicates that bourb credtit is required for the PWR configuration only. (This is discorssed io mo:e detoil under GERTIFCAMON ISSUES).

The fuel chencteristics assomed for the preliminary

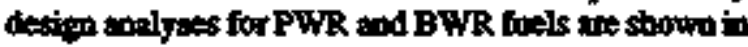
Table 7.
The contug ate code, KENO.IV, was used to evaluste criticality safity for both PWR and BWR configurtions with on tssunption thet the container intemnks we flooded, thens adding conservetissn to the malysia. Doring furt design, more realistic essemptions will be used in acondence with NRC regulations. Other codes supporting the ansyats included:

- ORIGEN 2 - to develop PWR bortop istropies

- NULIF - to identify the most neacthe PWR fued

- NITAWL 8 - to geneante cross-nection deta XSDRNPM. 


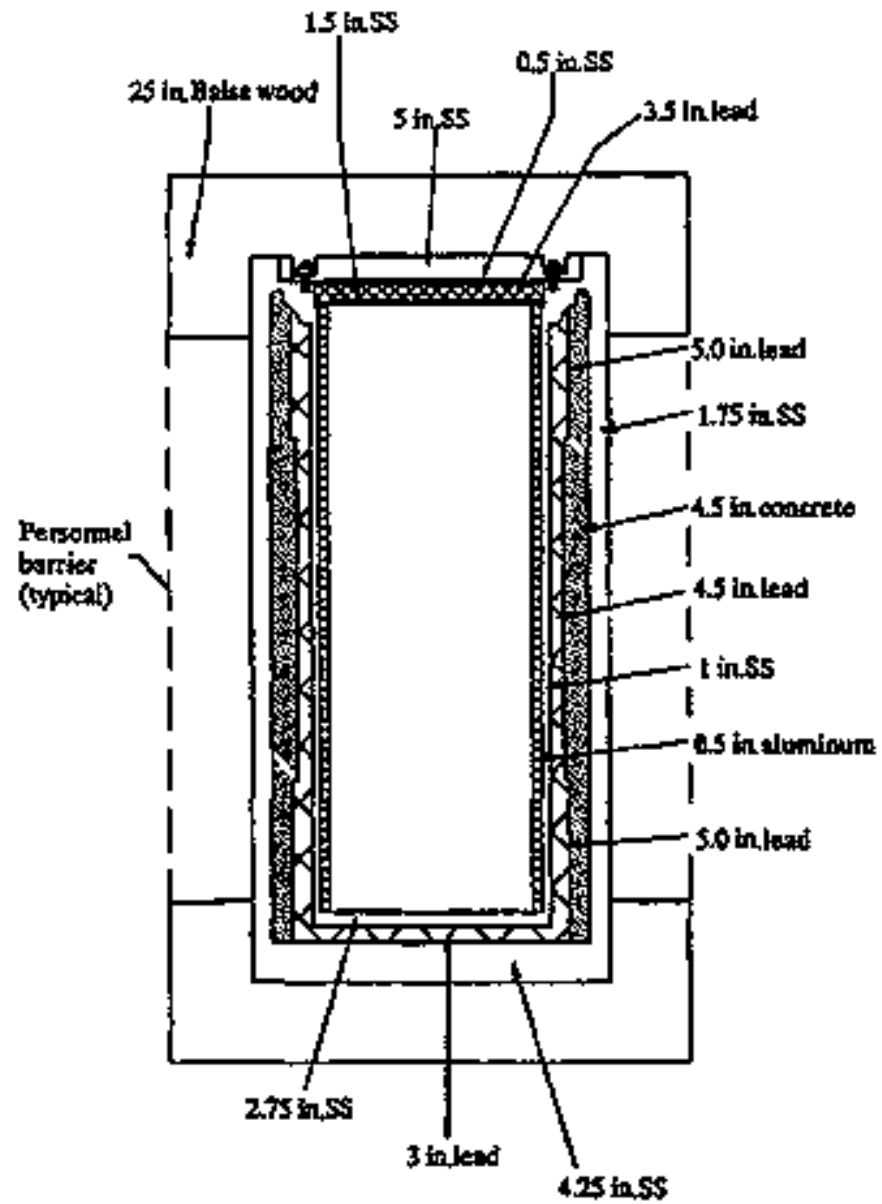

Flgure 2. BR-100 cant schematic of strielding materials.

Takale 5. PWR dose rates for notmal operating conditions

\begin{tabular}{|c|c|c|c|}
\hline \multirow[b]{2}{*}{ Locition } & \multicolumn{3}{|c|}{$\begin{array}{l}\text { Dose Rate } \\
\text { (m)th/h) }\end{array}$} \\
\hline & Neintod & Ganna: & Total \\
\hline 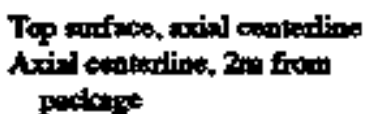 & $\begin{array}{l}47 \\
0.1\end{array}$ & $\begin{array}{r}49.5 \\
8.8\end{array}$ & $\begin{array}{r}54.2 \\
8.9\end{array}$ \\
\hline 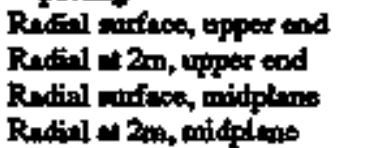 & $\begin{array}{r}7.1 \\
1.9 \\
15.2 \\
3.8\end{array}$ & $\begin{array}{r}112.9 \\
6.9 \\
20.9 \\
5.8\end{array}$ & $\begin{array}{r}120.0 \\
8.8 \\
36.1 \\
9.6\end{array}$ \\
\hline
\end{tabular}

Table 6. Desiga fiatores requitred to mext criticelity critbrian

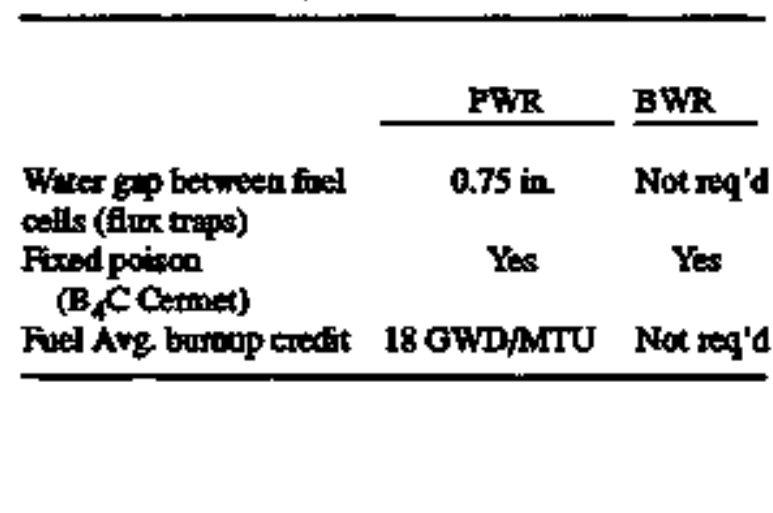

\section{OUALTY ASSURANCE}

The desion, texting, fabiction, and operation of the BR-100 shipping conthines will be pertotnet to so. quirementre specified by a Qunitity Aesurano Propram (QAP) generoved by B\&W, and sppnoved and sodited by the NRC, DOF, and DOE's subcootractur, EOESG
1960. B\&W's QAP is in acendence with notionstly

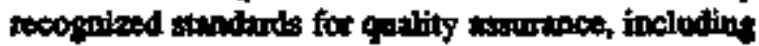
Americun Notional Stantinds hetit te (ANST)NQA-1 and American Society of Mechanicul Engineer. (ASME) Boiler \& Prewi.. In Vecsel Code, Section III. 
Documentution of NRC's QA aproval is provided in NRC Docket No. 71-0506-Rer. 2.

Fightights of B\&W's QAP implencentation for the BR-100 preliminery design phase include:

a Baseline drawings, calculations, and specifications were prodtuced in accordance with design and control procedures. They were independently reviewed by atralified individuals to ersume their tochrical acouracy.

b. Competer software wes cottrolled in 30 condance with the QAP requitements for pretimimary desigo.

c Testing was performed in accordance with requirements conmeneurate with the scope of approved test plans and procedunes. d. A desiga teview by independent experts was condacted to enorore thet all DOE and NRC requirements and indestry objectives for anfety and reliability were properly addressed in the BR-100 design

e. The peer review requirements imposed by DOE docoment $R$ W/0032 are impiemented in the BR-100 project throagh the technical and design neviews mentioned above, as well as by cooducting quarteriy reviewa by an Advisory Review Bourd (ARB). The ARB is comprised of senior engineers and managers from Baboock \& Whoos, Robatel, and utility and rethosed industry consolternts. In odfition, specificindepeodent revievs are beld on in sorneded basis.

Tevie 7. Asquasd foel chincteristics

\begin{tabular}{|c|c|c|}
\hline Parripeter & PWR & BWR \\
\hline $\begin{array}{l}\text { Assendibly rod andy } \\
\text { Active foud length, in. } \\
\text { Fuel rods/assembly } \\
\text { Puel mod diometer, in } \\
\text { Cinding naterial }\end{array}$ & $\begin{array}{c}W 17 \times 17 \\
144 \\
264 \\
0.36 \\
70-4\end{array}$ & $\begin{array}{l}\text { GE } 8 \times 8 \\
138 \\
62 \\
0.483 \\
\text { Zा102 }\end{array}$ \\
\hline 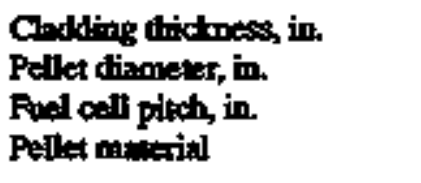 & $\begin{array}{l}0.00235 \\
0.3088 \\
0.496 \\
\mathrm{UO}_{2}\end{array}$ & $\begin{array}{l}0.032 \\
0.41 \\
0.641 \\
1 O_{2}\end{array}$ \\
\hline $\begin{array}{l}\text { Mexisum in'tial enrichneat, } \\
\text { w \& U-235 }\end{array}$ & 4.5 & 4.5 \\
\hline $\begin{array}{l}\text { Design basis burip. } \\
\text { GWDMMU }\end{array}$ & 35 & 30 \\
\hline $\begin{array}{l}\text { In'tial wainium weight, } \\
\text { lof sstembly }\end{array}$ & 4232 & 176.8 \\
\hline
\end{tabular}

\section{CERTIFICATION ISSUES}

B\&W met with the NRC three times doring the BR-100 preliminary desifo phane. Representatives from DOB and their subcoutractors were olso presect at these newings, which are recouded is the NRCPab. lic Docrment Room under Docket Number 71-9230. The parpose of these meetings was to describe the
BR-100 design to the epproprian negolotory experts

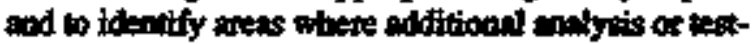
ing wold be requited for certificotion Avers that noquite special attention bave beta clastified is

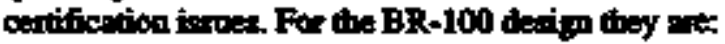


2 Thermal Switch/Neutron Stileld - The borated cemen $/$ copper fin feature bas not previously been centified by the NRC; therefore, ins performance most be vedfied ithrough testing.

b. Closure Seals - Both materiol papperties and configarcion performate must be verified by westing over the range of regolatory temperature conditions.

c. Inpact Liniters - The specifications to be used for fabrication of the production inpact limiters tat to be doplicated for test specimens. The performanece of the test specimens will be docmented over a tange of predicted worst-case conditions and benchmarked to a computer code that will then extropolate the finces applied to the containerith any poetul sed drop accident. d. Burrow Credit - The BR-100 ases butoup crodit coly for PWR foel with in:tial U-235 enrichenents ower 32\%. Bumpup is a torm that describes the amoun of t-235 in a foel assenbly the has been reed, of "burned" As the U-235 in a fuel assembly ts "burned," less is available for further beak genersion. The criticality analyses performed on the BR-100 assume a "burnup ctedit." This is a means of socounding for rothoed reavivthy as a result of the fitsile material (U-205) depletion and brild-op of fission product poisons.

Safficient analytical dats to cover all fuel-related parameters and a verification techinigue to ensure the requined beruop level will be necessary for inclosion of burmop credit in the certification process.

\section{TRANSPORTER SYSTEM}

The transport system for the BR-100 shipping contwincr consists of a nilkar, skid, and personnel barier. The sylem is shown in Figure 3.

The riller meets AAR mquiremeins to allow free interchange on all major U.S. rilroods. The rilcer is 47 ft 6 in long and 10 ff 6 in. wide and rides on two 2-axle trucke, The Gross Vehick Weight limit on the loaded rilikar is $263,000 \mathrm{lb}$, or $65,600 \mathrm{Hb}$ per axle. The reilear weighs $45,000 \mathrm{lb}$ and is a fatbed with provi. sions for ataching the stipping skit and trolltes on etch end for romoring and stoning the impant finitars.

The railcar is designed for easy inspection and mintencuce and has hightporformouce mining goar and brids per AAR guidelines. The two-truck toofigwration was chosen becanse of is stability and relicbil. ity. The center of gravity of the contriner is $92 \mathrm{im}$. above the roils, less than the 98-in. maximum recommonded by AAR, A tide index will be spectited th the find design that is consisten with stuctural anilysis and texting. The failcar design will be approved by the Aar before operation.
The stipping stid holds the BR-100 contsiner secure during all conditions of transport and is compatible with either rail or barge shipment The did is secured to the BR-100 contrires and alkows roution of the contriner between vertical and hotizootal vil two tronnions near the rear (bottom) end of the conniner. The truonicos ane chiset 50 that the containes can only rotate in the coarect direction. The stid has a sadile that sapports, and holddown brackets that retain, the from end of the BR-100 container. The stid can be picked up while holding the BR-100 contriner via two

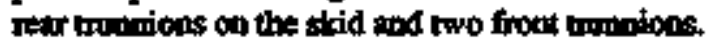

The persunel barriter for the BR-100 conviner exteods between the two inpect limitess to preveint any indvertent confact with the contriner bady. If is made

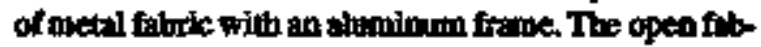
ic allows air circulation anound the contain-s, while the white color and partill solar protection betp redoce we outer bemperatude of the coutainet. The persomel

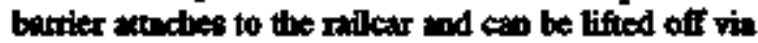
lifting eyes on top of the fimme.

\section{ALARASAFETY CONSIDERATIONS}

Desigu constideprions for the BR-100 thipping conwines tomorporate ALARA (As Low As Reasoositly Achiequble) ard sufety as integril parts of tedesion
Frocess.ALARA hus astis go:l the systenic reduction of wotrer and poblic exposine to woitplace natiation The BR-100 desten team includes exvenl menbers 


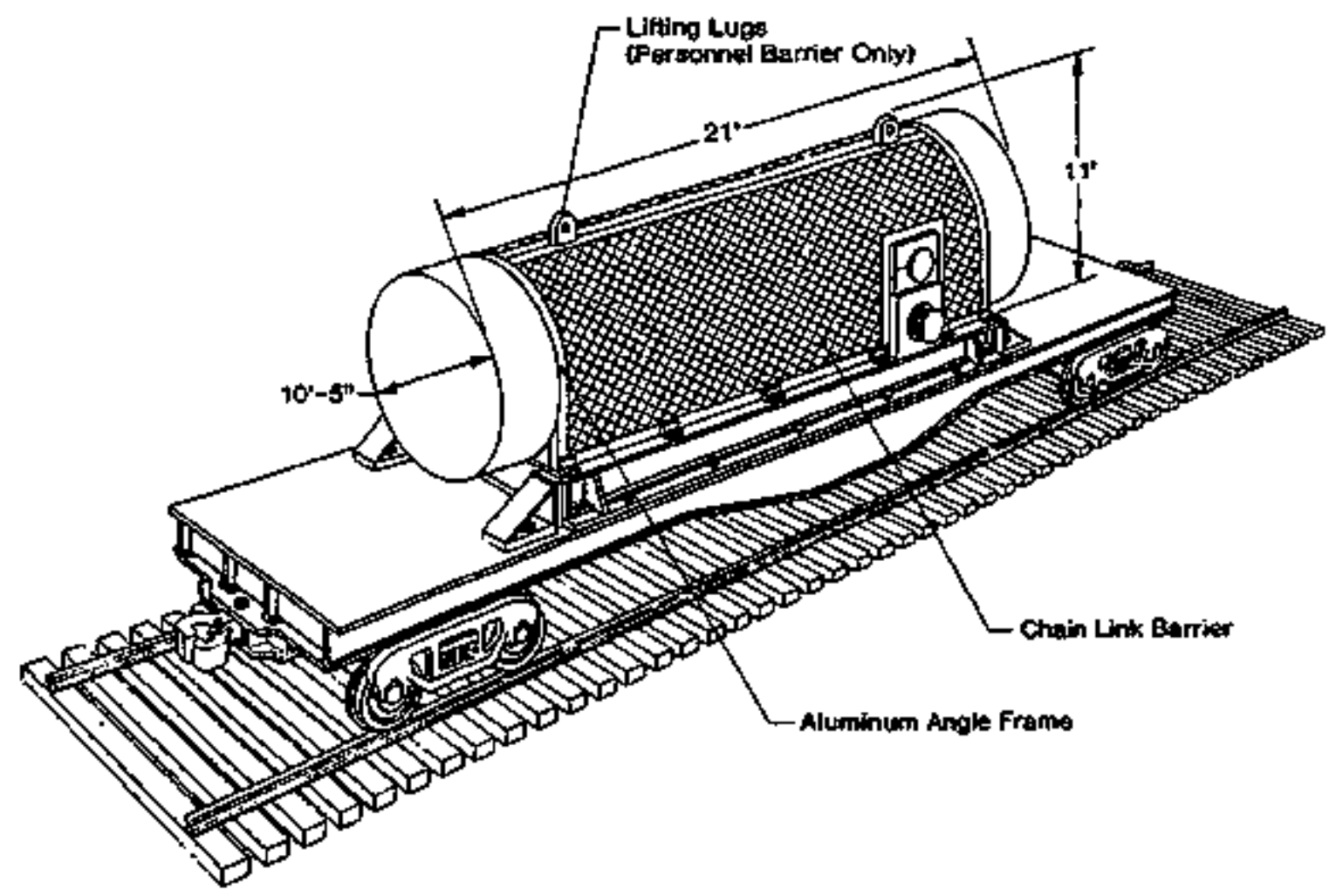

Figure 3. BR-100 ceste on raileas.

experieced in ALARA principles, and the BR-100 design undergoes peniodic review by ALARASsofety experts.

Design teatutes that coatribote to ALARA and Safty goals inclode:

- Borated cencent/copper flus -- This fitmure ensures that both the contrinet neutron stitid and benman stikld with tomith effective after bypotheticil scoldert conditions.

- Two-piece closure - The lid/4hield plug sysrem tllows quicter operations to preputing the cortainer for tipunent, thes rodacing tio. tal woater expostre. The closure bid is never inserted in to the pool wnect, firther mintaizing contaninerion.
- Srocthexterior - The BR-100 dexign has no cooling fins and has minimal protrusion and crovices. This teeps cleaning and decontamimotion efforts sinplo and effective, and helps to beep woiline exposute to a minimum.

- Quict aftechmen's - The clostre and impact limiter atechment bolts are designed for twy instillation and disesseanbly by being com. patitle with remote and nemovely entompted equipment.

- Prepartion for shipencet - All drintog, drying, inerting, and leak esting opersioes ane performed at the top of the contsinec This ensures better stivelding, lower exposuses, and sater eperations.

\section{RELIABILTY AND MANTANABILITY}

The BR-100 coostiner sytem, including the roilker,

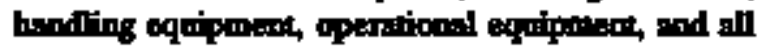
other ancillary equlpnowh wes reviowed in the prelim. intry design pinte usint a Fillute Modes and Effects

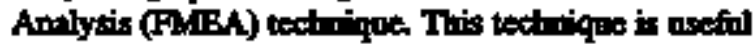

in identifying the probebitity and consequences of any potertial frilure machanism and thes helps enablish

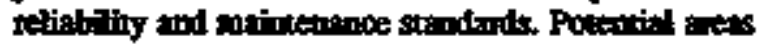
thrt are atverse to relinbility and nninteninbility a identified and comeated as a regiti of the PMRA. 
Before operations and maintenape manuals are prepared dutiog the final design phese, and before the ancillary equipment and con siner design has been ifnolly whother FMEA will be performed.
In addition, the BR-100 system dexign is reviewed $0 n$ a quartietly basis by m independent panel that includes contriner users, fabricators, and inrpectors. Their inpes ca the efficiency and pafecy of the design is then used for revisions and opdates. 
Appendix E-3

M-140 Cost Information 
Fom : 1. ห. Pratt

aw : August 31, 1993

surind: RIF Contuiner Costs

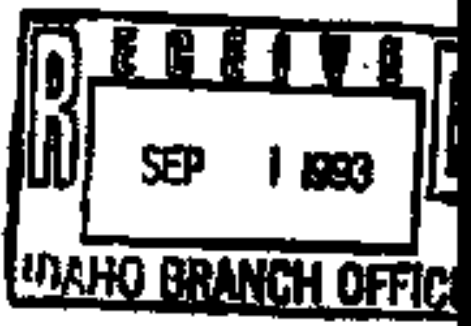

To : A. H. Elchardson

Pưrlsuant to our conversation yesterday, herle is the rous ining inforation on the containar processing costs and design parantios.

As earlier stated, the $M-140$ cask, internals, and wit. cil cost approxtately \$4,000,000. The intermals contributed around $\$ 300,000$ and the raji car contributed around $\$ 250,000.1$

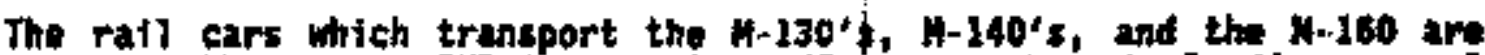
owned by the Aray. PHR tracks the ratl kars and coatrols the general maintenance of the rail cars. ATl of the $M-140$ rail cars were purchased within the Naval Reactors progran and not by the Aray.

The core independent \$inp indicates a heat rewoval capactty of 75,770 Btw/hr. Par a conversation with Bett1s (Cramford), this capacity is dependant on the fuel modules and andyle hojders Insida, but for a general dnsign number this nuber can be used.

The transportatien costs of an M-130 and M-140 are dependant on waight of

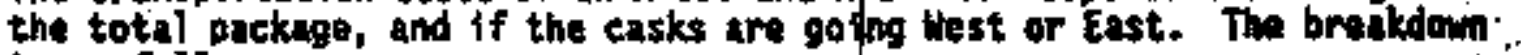
is as follows:

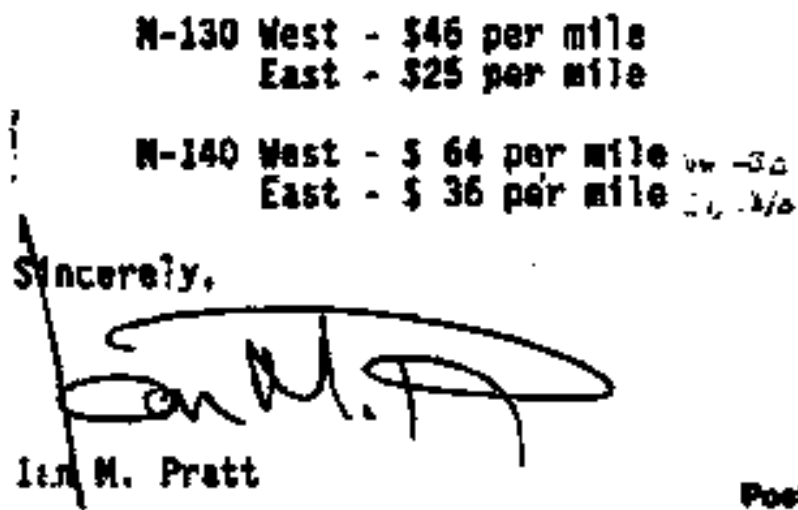

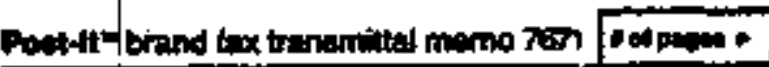

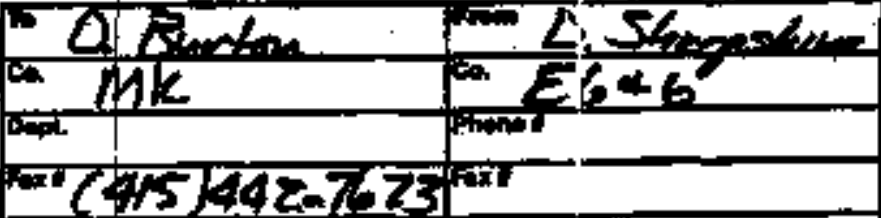


1700 Eas Goll Rond

Schuantoug, nlinois 60173-5860
June 4, 1993

Mr. David Euxton

Transportation Specialist

Morrison rnudsen corporation

Environmentel services Division

180 Howard Street

San Francisco, Ca 94105

Dear Mr. Burton:

This has reference to your fax request of hay 27, requenting a rat 1 cuotation on shipment of spent nuclear fuel oxiginating from Forris, IIlinois (rail head argonne, Iliinois), terminating Ios Alanos, Waw Haxico, (rail head Albuquerque, Hew boxico).

Please find attached copy of santa Fe Tariff 4043-A covering shipments of nuclear wastes on both loaded and expty novements.

This tarift is set in nilenge format, with rates and charges assessed tor the distance sante fo sctulity handios ecch car.

our tariff doas not include rates applicable to cabooses or guard cards. We are inventigating these rates which will be supplied in the near future.

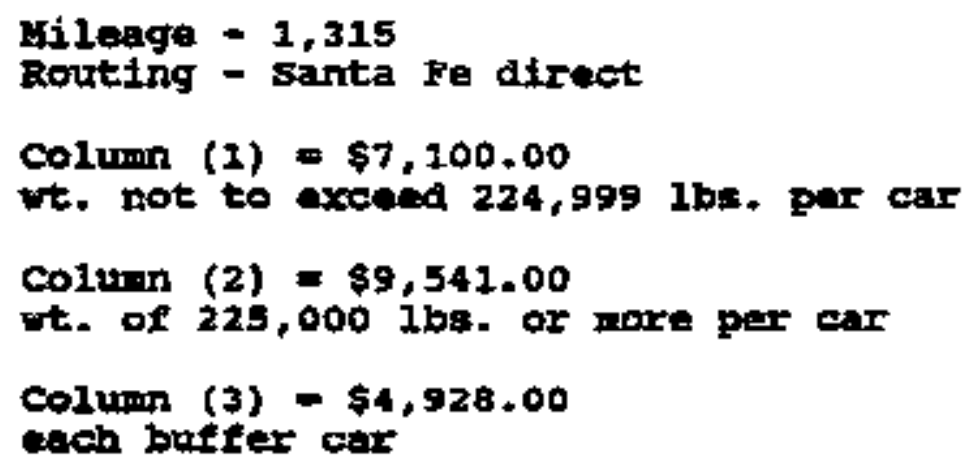

worrimen Knuasen wi11 need to telect and provide for a loading tite at orjgin and an unloading site at deotination, as well an, provide for transportation from Hoxxis, Illinois to Afgonne, I1linois and From Albuguergute to Los Mlamos, Kaw texico since santa Fe does not serve these loctions, nor do we provide for over the roud transportation. 
Please let us know if you roquire any aswistance in locating rail sarved property at either origin or destination, an well as let us know how we can further assist your efforts in moving this product.

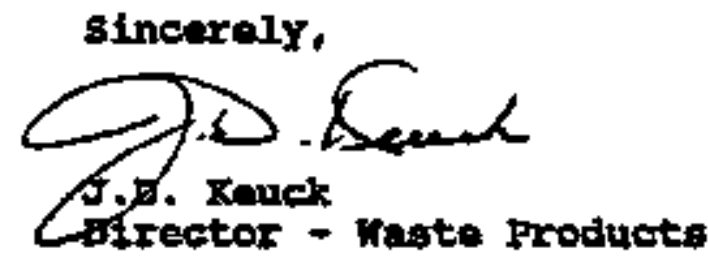

Jif af 


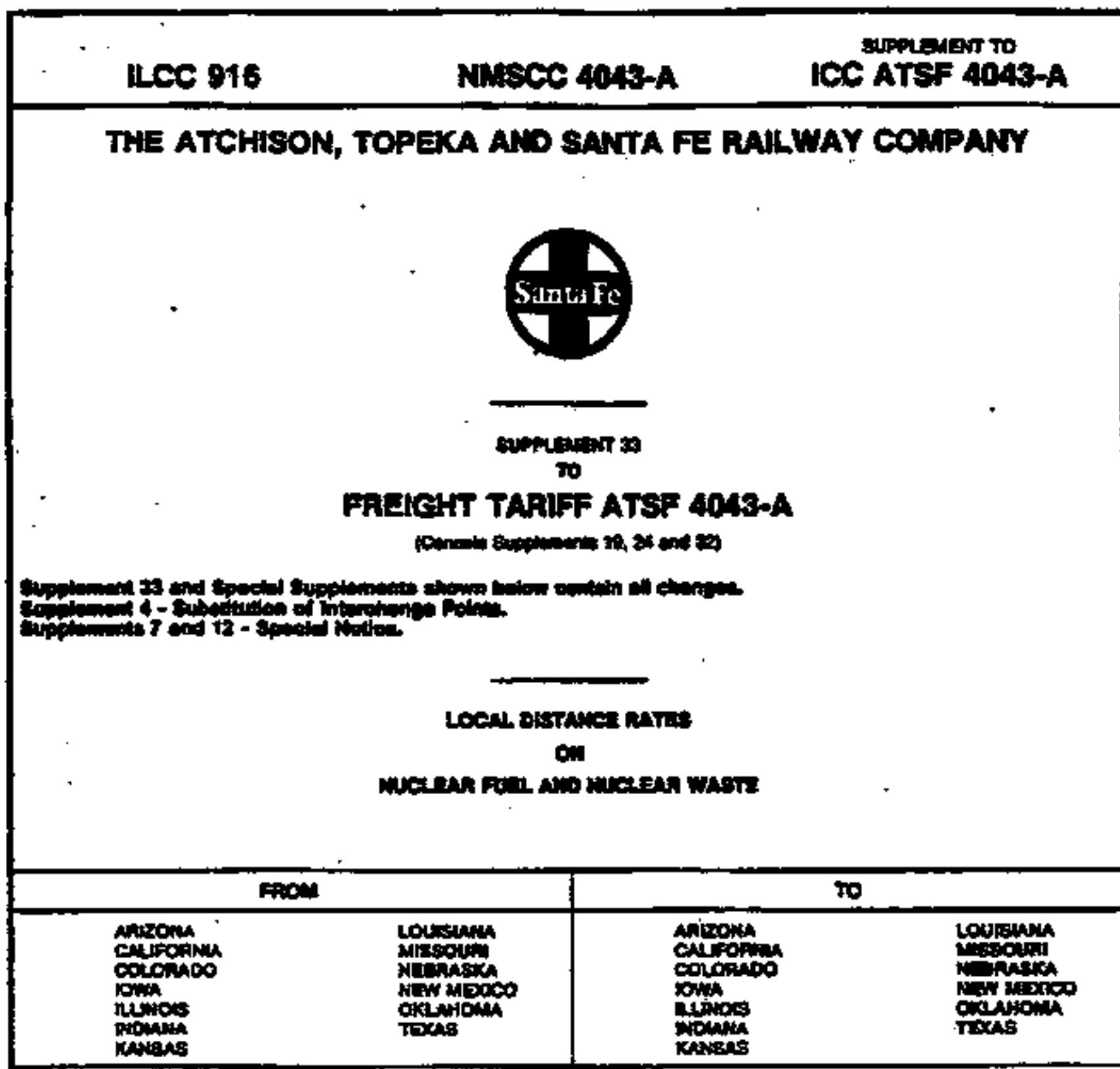

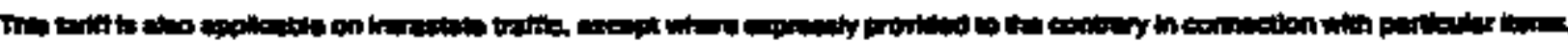

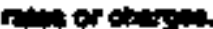

\section{NUCLEAR TARIFF}

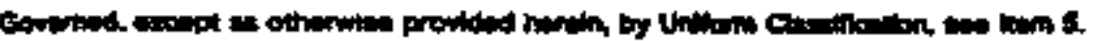

ISSUED Nㅏㅈ, B, 1902

EFFECTIVE AHLY 29, 1092

axis or

D. 1 to

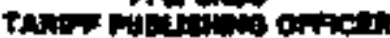

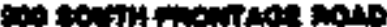

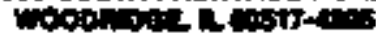




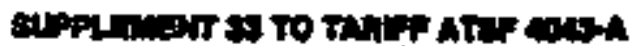

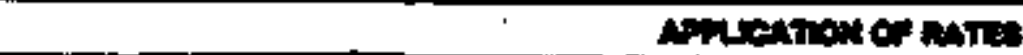

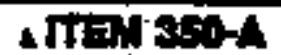

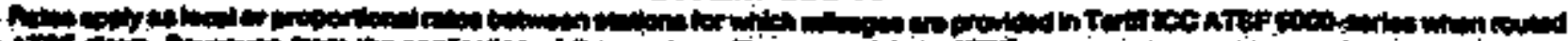

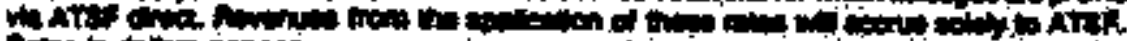

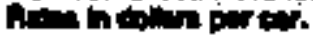

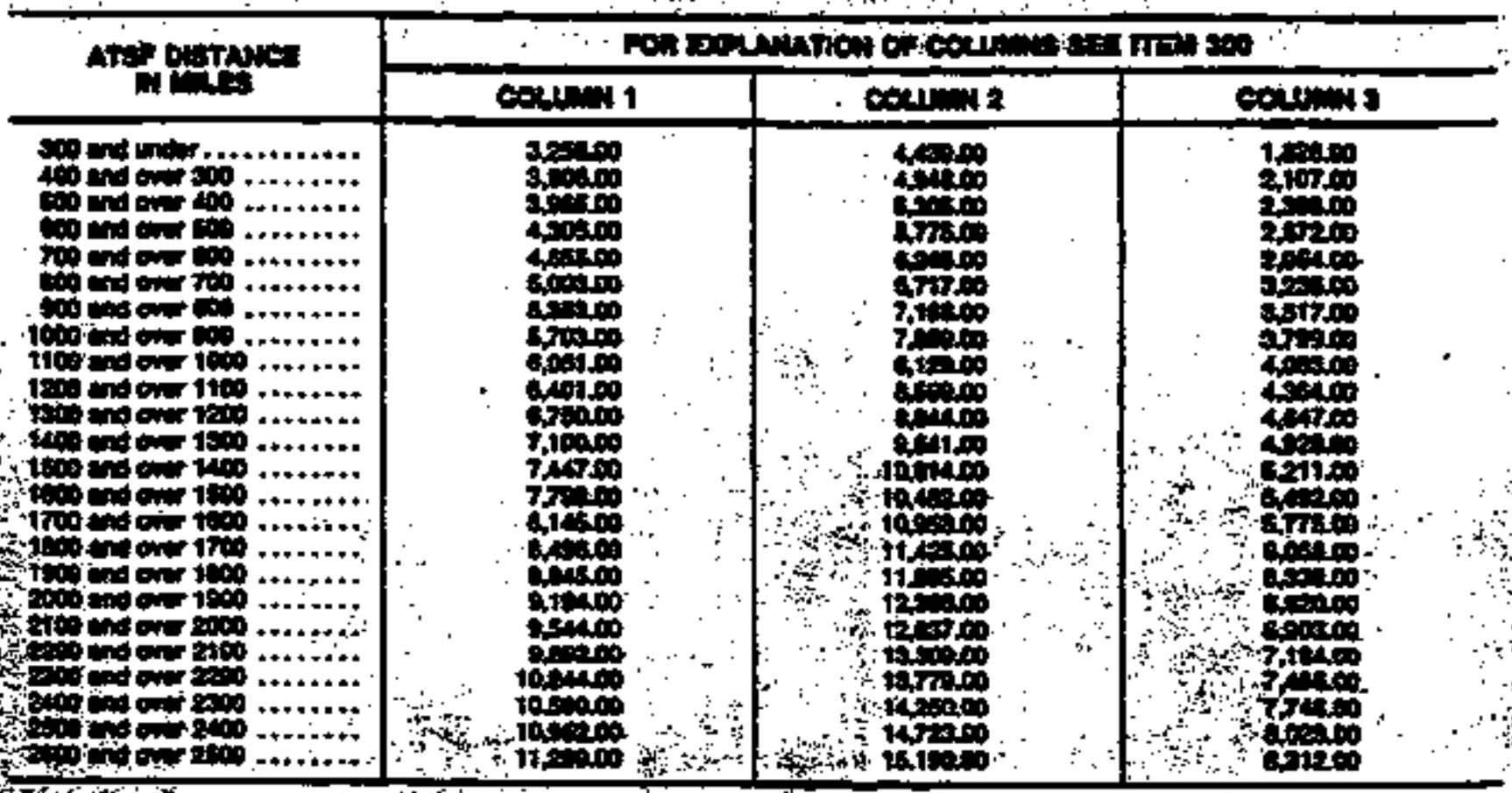

W

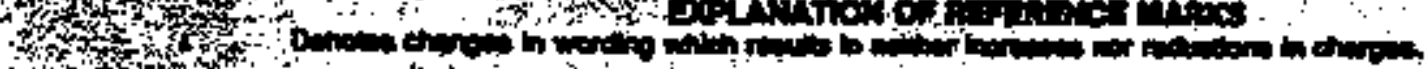

$\therefore$

$\therefore$ (1)

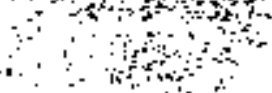

更

is
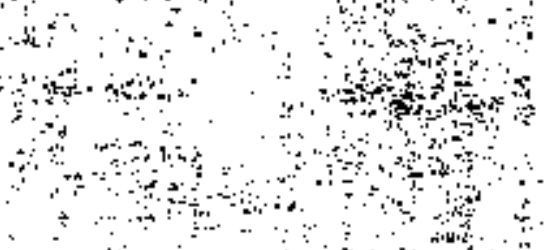

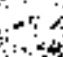

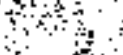

ar
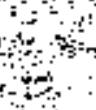

and

$\because+4:-$

$\because \because$

ث:

$\because 8$

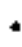

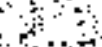

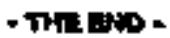




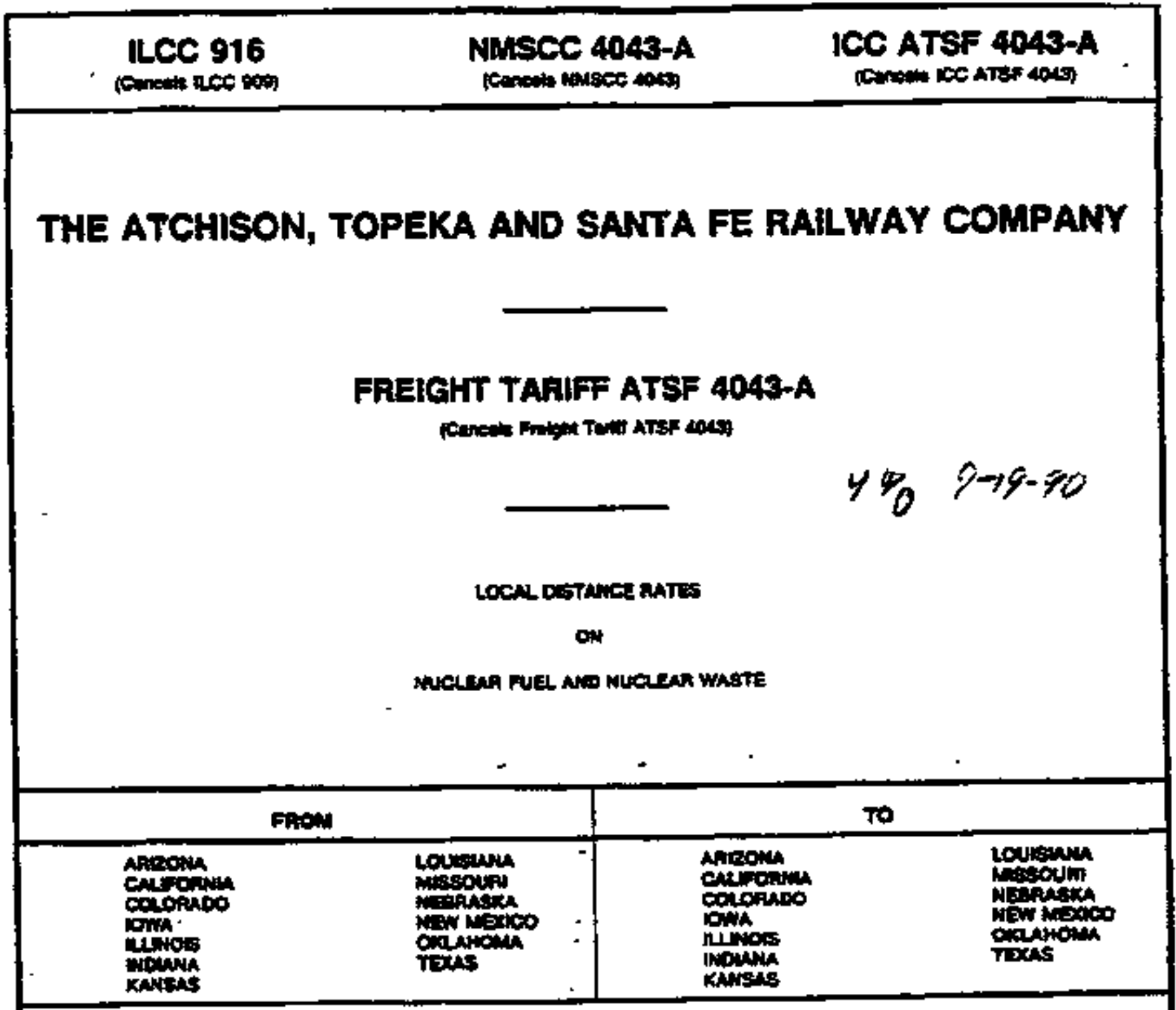

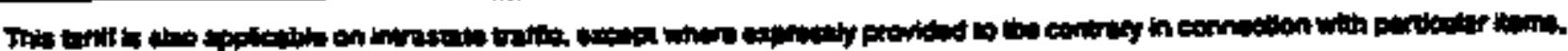
nots of therem.

\section{MELEAR TARIFF}

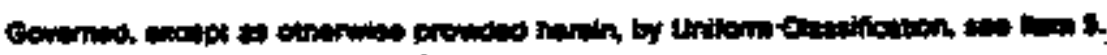




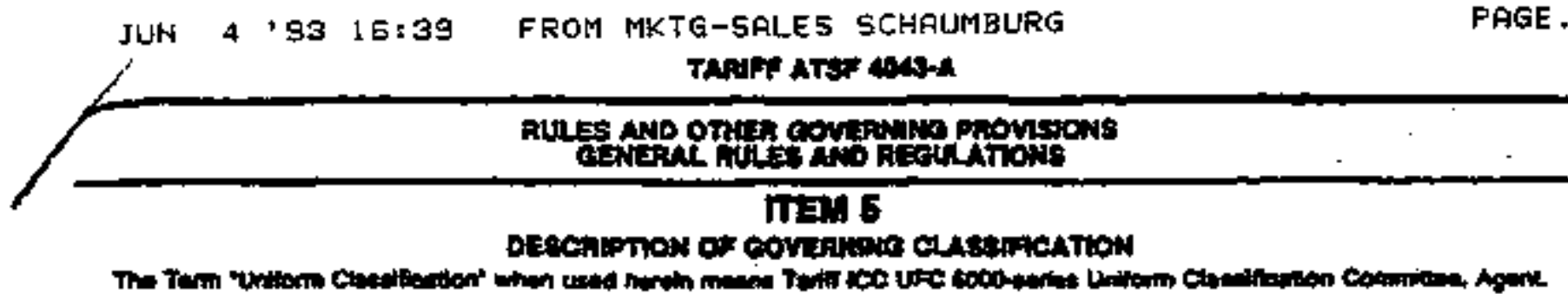

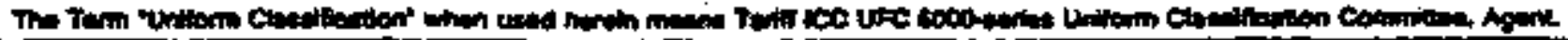

\section{III) 10.}

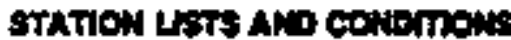

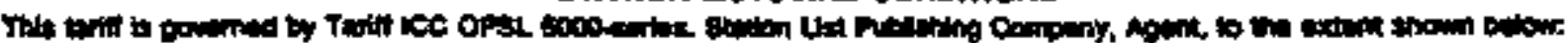

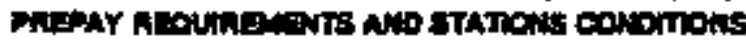

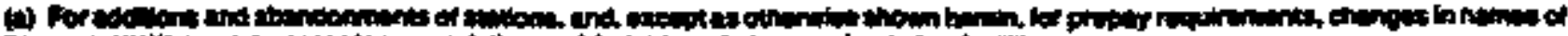

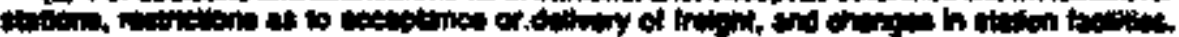

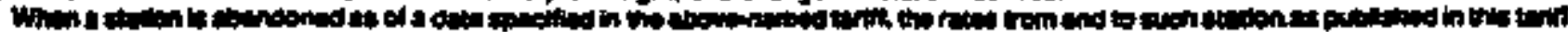

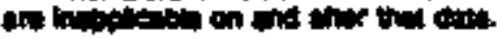

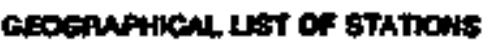

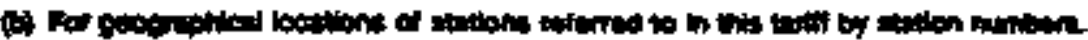

STATDN Muncists

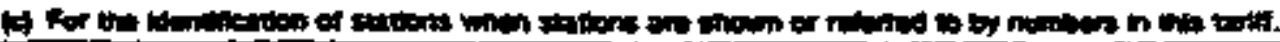

\section{IIE: 15}

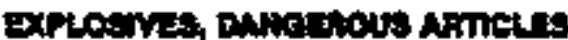

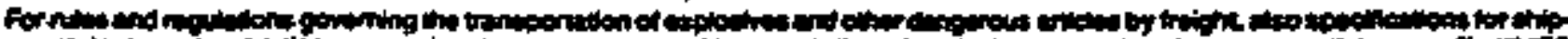

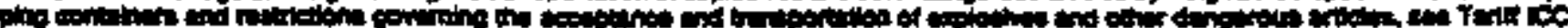

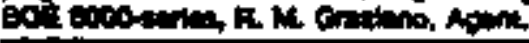

\section{Irtin 20}

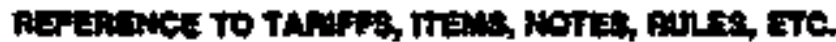

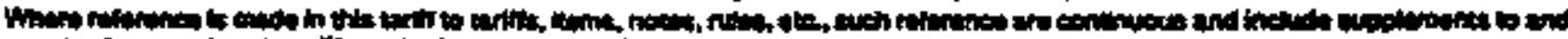

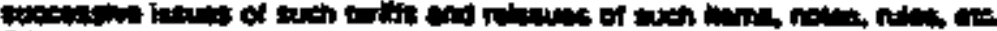

.

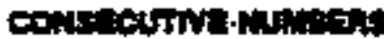

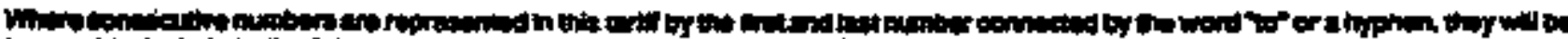

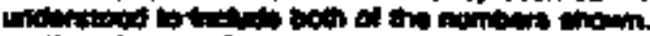

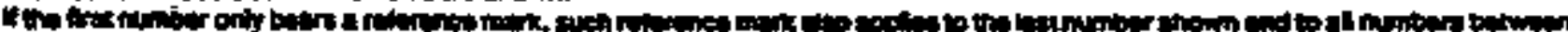

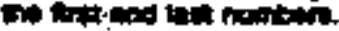

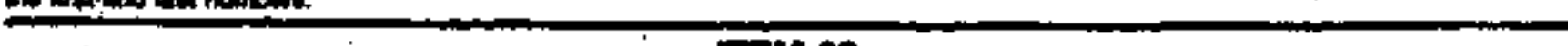

\section{ITEM 60}

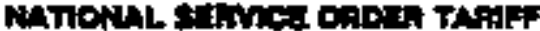

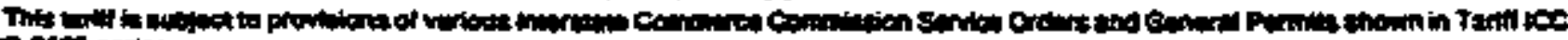

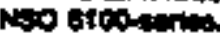

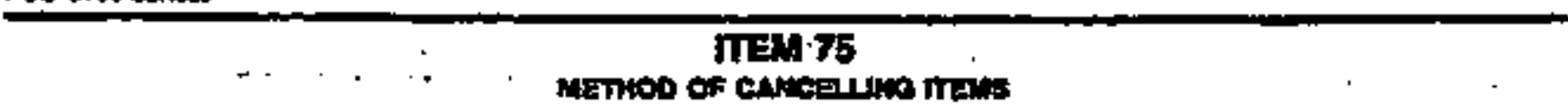

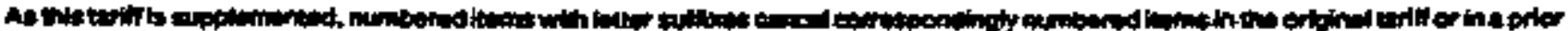

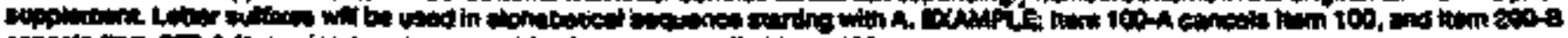

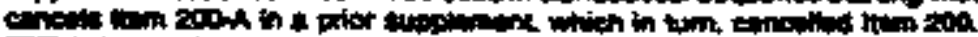

. - - -

TTEAI 100

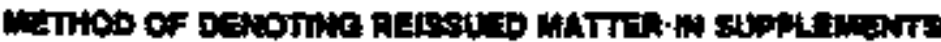

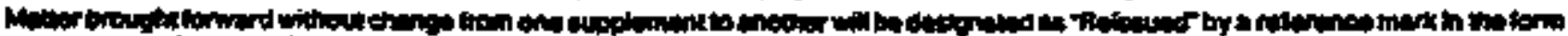

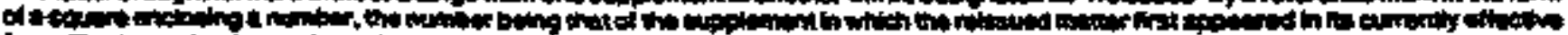

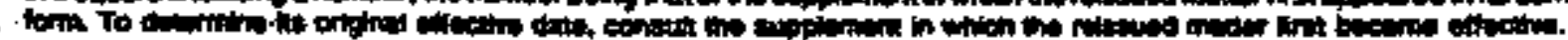




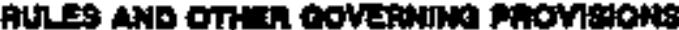

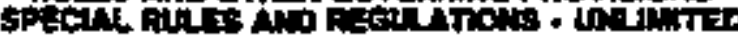

\section{ITEN 200}

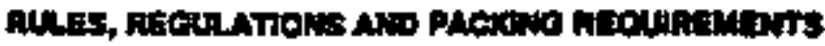

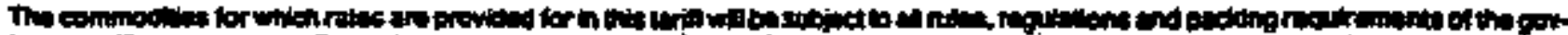

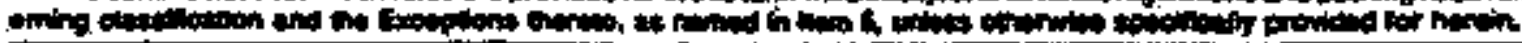

\section{ITE: 210}

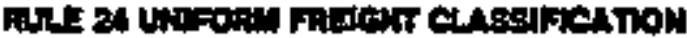

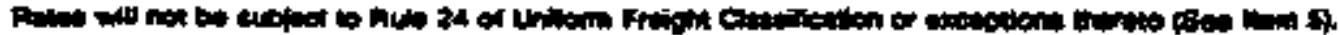

ITEM 200

How

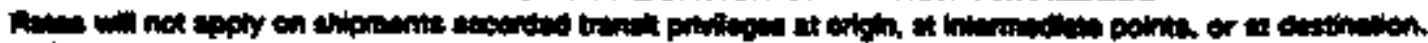

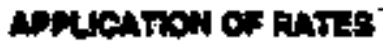

ITEMA 360

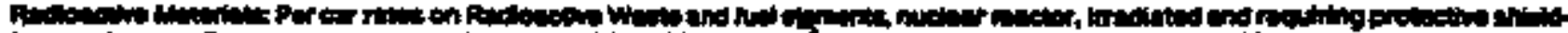

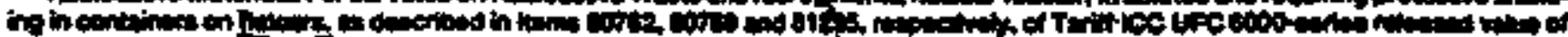

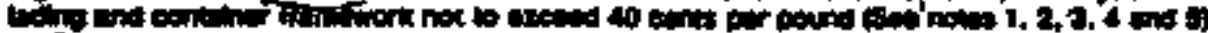

P.

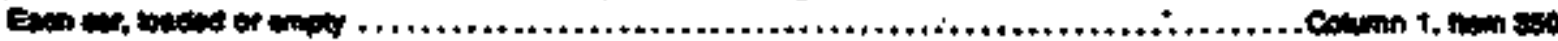

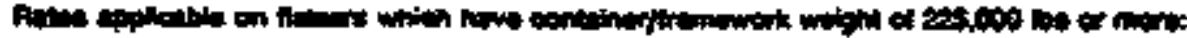

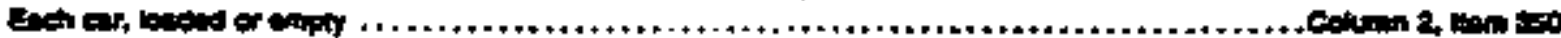

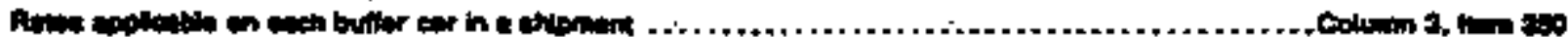

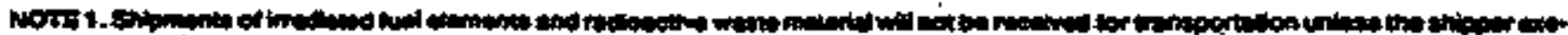

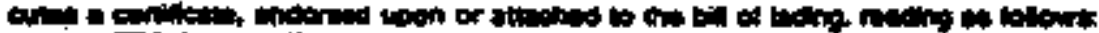

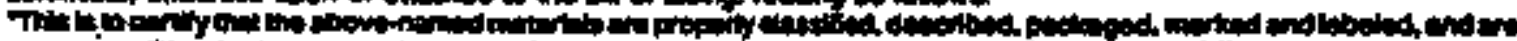

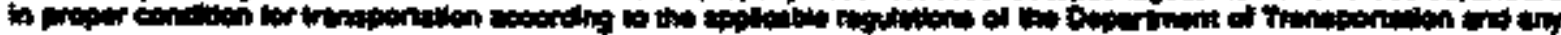

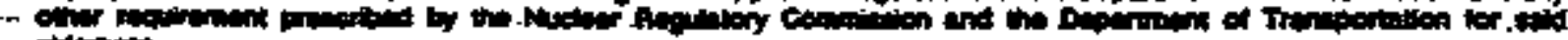
(1)

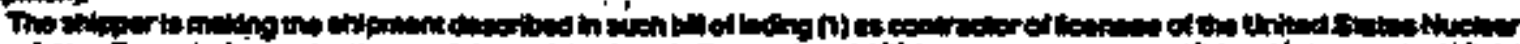

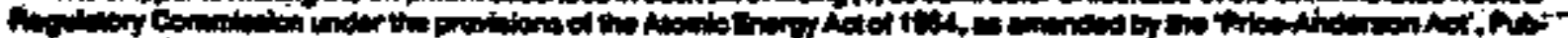

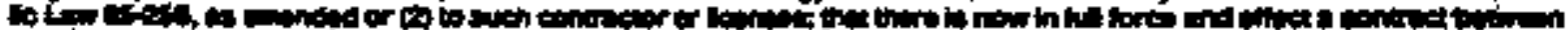

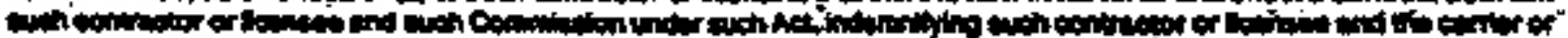

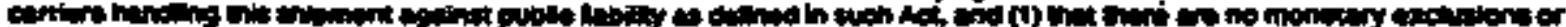

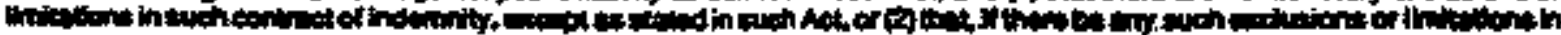

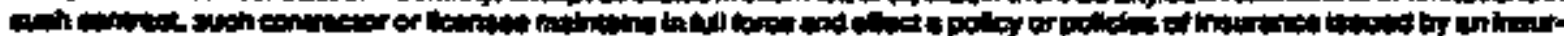

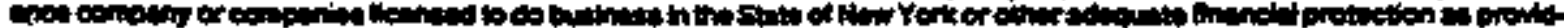

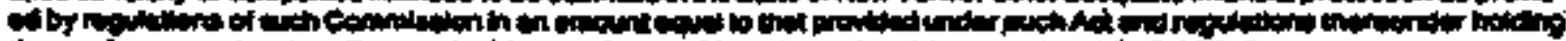

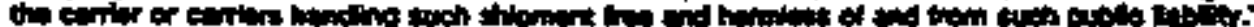

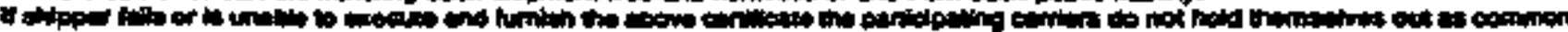

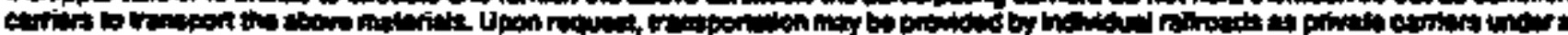

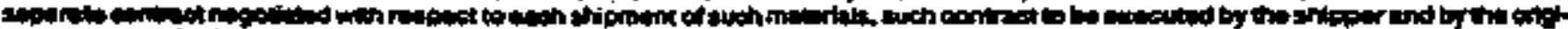

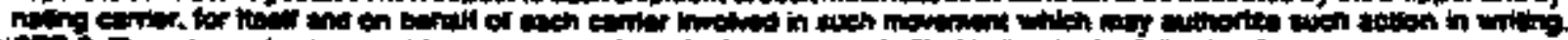

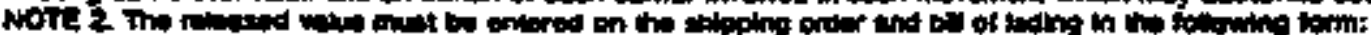

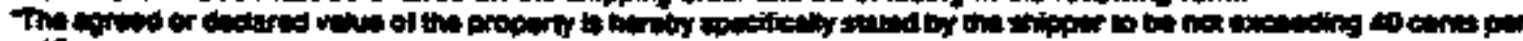
pernd."

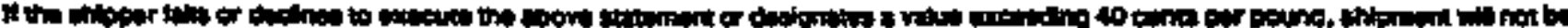

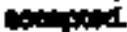

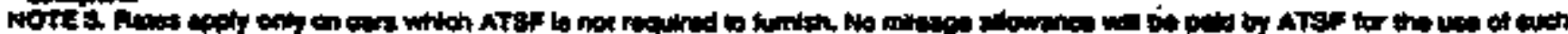
etcis

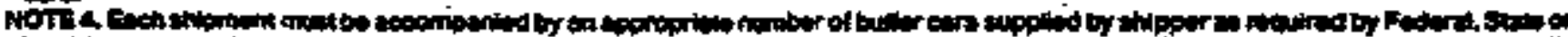

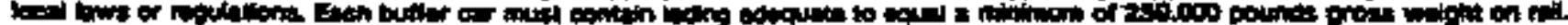

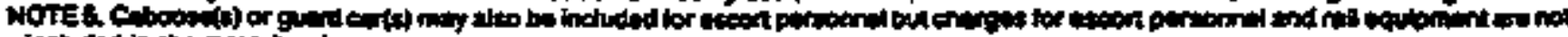

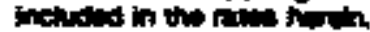


Appendix F

Transportatlon of HLW Canlsters 



\section{Appendix F}

\section{Transportation of HIW Cmisters}

Very limited cost information exists for shipment of HLW canisters. However, on the basis of numerous reports, there is general agreement that transportation costs for $H L W$ would be similar to SNF, for which cost data are avaitable. The total cost of transport is defined to be the sum of capital costs, maintenance costs, and shipping costs. Detailed cost algorithmes exist to estizalate the cost of shipping SNF in repository casks from a reactor site to another site, including the national geologic repository (U.S. DOE 1986, 1991; Tang and Saling 1990). In general, to calculate the total required number of transportation casks, information on average speeds, cask turnaround times, and avgilability of casks must be known or estimated. This determines the required number of shipping casks to support the scheduled shipment of HLW canisters from one site to another and from a given site to the geologic repository. Bectuse of the lack of information on the shipping rate and the number of HLW shipping casls to be assumed for the various alternatives, a more generic approach was used based on a urit transportation cost. (The HLW shipping cask design to be assumed was determined to be very important, as shown by use of the cost algorithm in Tang and Saling 1990; order-of-magnitude differences in the total transportation cost resulted from using two different shipping cask designs.)

A unit transportation cost (by truck) of $\$ 10,000$ per canister bas been quoted in the literature (Tang and Saling 1990; DOE 1990). The above unit transportation cost was developed on the basis of 17,750 HLW canisters generated from defense operations; these canisters would be shipped from the three major HLW sites (Hanford, INEL, SRS) to Yucca mountain. The abowe unit cost does not acoount for the distance traveled. This deficiency is now addressed.

The total transportation cost for shipping $17,750 \mathrm{HLW}$ canisters has been estimated to be $\$ 297$ million in 1988 dollars (DOE 1990). This cost covers the capital costs of purchasing the transportation casts and conveyances and the operating costs of accepting the waste and providing all required transportation services (e.g., cask maintenance cost, demurrage cost). The total number of canister miles was estimated (Table F-1) on the basis of the distribution of canisters among the three defense HLW sites and the distance of these sites to Yucea Mountain.

The unit transportation cost is estimated based on total canister miles and transportation cost:

Unit transportation cost $\$ H L W$ canister mile $=\$ 297 \times 10^{6} / 2.564 \times 10^{7}$ canister miles $\times 1.184$ $=\$ 13.7 / \mathrm{HLW}$ canister mile

where the factor of 1.184 converts 1988 dollars to base operating year (BOY) 1994 dollars.

Given the number of HLW canisters to be shipped between the various sites and the shipping distance, the above unit cost is used to determine the effect of shipping the various number of HLW canisters for the different HEW alternatives. The total undiscounted transportation costs for the various alternatives are given in Table F-2 in BOY 1994 dollars. The estimates of the total transportation cost in Table F-2 agree with those projected by DOE (329 million 1991 dollars). The lowest-cost alternative (as expected) is the no-action case. 
Table F-7. Determination of the total number of canister miles.

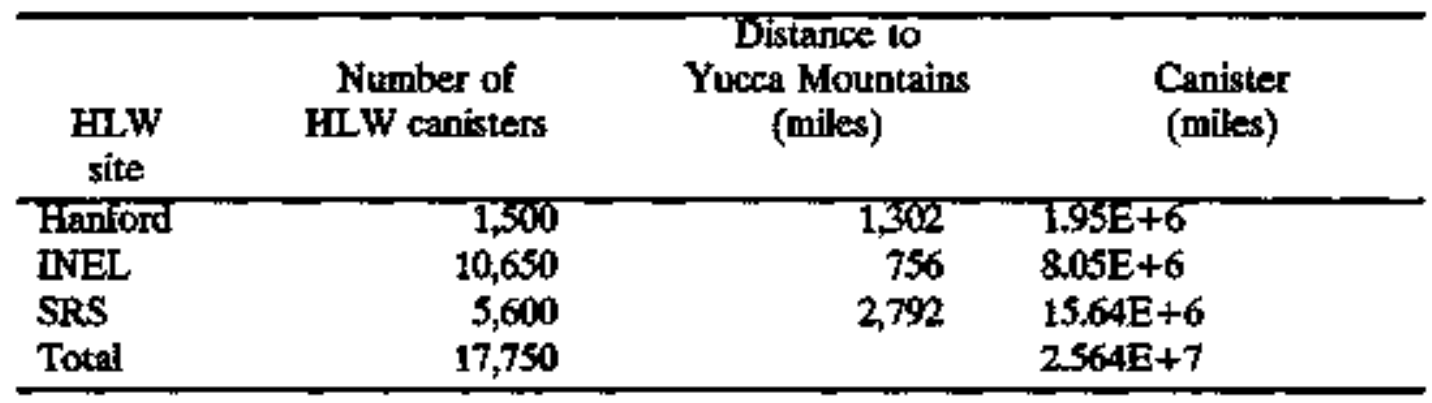

Table F-2. Transportation cost for the four HLW alternatives.

\begin{tabular}{|c|c|c|c|c|c|}
\hline $\begin{array}{l}\text { Case and } \\
\text { origin }\end{array}$ & Destination & $\begin{array}{c}\text { No. of } \\
\text { shipments }\end{array}$ & $\begin{array}{c}\text { Distance } \\
\text { (miles) }\end{array}$ & $\begin{array}{l}\text { Total distance } \\
\text { (miles) }\end{array}$ & $\begin{array}{c}\text { Total } \\
\text { transportation } \\
\text { cost }(\$)\end{array}$ \\
\hline \multicolumn{6}{|l|}{ No-action } \\
\hline WVDP & Yuoca Mtn & 300 & 2540 & $7.620 \mathrm{E}+05$ & $1.05 E+07$ \\
\hline SRS & Yucca Mtn & 5,282 & 2,839 & $1.500 \mathrm{E}+07$ & $2.06 E+08$ \\
\hline INEL & Yucea Mtn & 8,500 & 756 & $6.426 \mathrm{E}+06$ & $8.81 E+07$ \\
\hline Hanford & Yuect Mtp & 1,960 & 1,302 & $2.552 \mathrm{E}+06$ & $3.50 \mathrm{E}+07$ \\
\hline Total & & 16,042 & & $2.474 \mathrm{E}+07$ & $3.39 \mathrm{E}+08$ \\
\hline \multicolumn{6}{|l|}{ Case 1} \\
\hline WVDP & SRS & 300 & 1,217 & $3.651 \mathrm{E}+05$ & $5.01 \mathrm{E}+06$ \\
\hline SRS & Yuce Mtn & 5,282 & 2,839 & $1.585 \mathrm{E}+07$ & $2.17 \mathrm{E}+08$ \\
\hline INEL & Yuce Mtu & 8,500 & 756 & $6.426 \mathrm{E}+06$ & $8.81 E+07$ \\
\hline Hanford & Yucea Mtn & 1,960 & 1,302 & 2.552E +06 & $3.50 \mathrm{E}+07$ \\
\hline Total & & 16,342 & & $2.519 \mathrm{E}+07$ & $3.45 \mathrm{E}+0 \mathrm{~B}$ \\
\hline \multicolumn{6}{|l|}{ Case 2} \\
\hline WVDP & Hanford & 300 & 2,654 & $7.962 \mathrm{E}+05$ & $1.09 \mathrm{E}+07$ \\
\hline SRS & Yucca Mtu & 5,282 & 2,839 & $1.500 \mathrm{E}+07$ & $206 \mathrm{E}+08$ \\
\hline INEL & Yucea Mtn & 8,500 & 756 & $6.426 \mathrm{E}+06$ & $8.81 E+07$ \\
\hline Hanford & Yucea Mtn & 2,260 & 1,302 & $2.943 E+06$ & $4.04 \mathrm{E}+07$ \\
\hline Total & & 16,342 & & $2.516 \mathrm{E}+07$ & $3.45 \mathrm{E}+08$ \\
\hline
\end{tabular}


Table F-2. (Cont'd)

\begin{tabular}{llrrrr} 
Case 3 & & & & \\
WVDP & Hanford & 300 & 1,654 & $7.962 \mathrm{E}+05$ & $1.09 \mathrm{E}+07$ \\
SRS & Hanford & 5,282 & 2,953 & $1.560 \mathrm{E}+07$ & $2.14 \mathrm{E}+08$ \\
INEL & Yucca Mtn & $\mathbf{8 , 5 0 0}$ & 756 & $\mathbf{6 . 4 2 6 \mathrm { E } + 0 6}$ & $8.81 \mathrm{E}+07$ \\
Hanford & Yucca Mtn & 7,542 & 1,302 & $9.820 \mathrm{E}+06$ & $1.35 \mathrm{E}+08$ \\
Total & & 21,624 & & $3.264 \mathrm{E}+07$ & $4.48 \mathrm{E}+08$ \\
\hline
\end{tabular}

\section{Appendlx F References}

Tang Y.S, and J.H. Saling, 1990, Radioactive Waste Management, Hemisphere Publishing Corporation, New York, N.Y.

U.S. Department of Energy, 1986, Perspective on methods to calculate a fee for dispasal of defense high-level waste in combined (Civition Defense) repositories, DOE/RL-86-10, Washington, D.C.

U.S. Department of Energy, 1990, Estimates of the total-system cost for the restructured program: an addendum to the May 1989 anahyis of the total-system life cycle cost for the Civilian Radioactive Waste Management Program, DOERW.0295P, Office of Civilian Radioactive Waste Management, Washington, D.C.

U.S. Department of Energy, 1991, Reference transportation data for the Civilian Radioactive Waste Management Program, Revision I, Office of Civilian Radiaactive Waste Management, Washington, D.C. 